Portland State University

PDXScholar

Spring 6-6-2013

\title{
Glacier Change in the North Cascades, Washington: 1900-2009
}

Kristina Amanda Dick

Portland State University

Follow this and additional works at: https://pdxscholar.library.pdx.edu/open_access_etds

Part of the Climate Commons, and the Glaciology Commons Let us know how access to this document benefits you.

\section{Recommended Citation}

Dick, Kristina Amanda, "Glacier Change in the North Cascades, Washington: 1900-2009" (2013).

Dissertations and Theses. Paper 1062.

https://doi.org/10.15760/etd.1062

This Thesis is brought to you for free and open access. It has been accepted for inclusion in Dissertations and Theses by an authorized administrator of PDXScholar. Please contact us if we can make this document more accessible: pdxscholar@pdx.edu. 
Glacier Change in the North Cascades, Washington: 1900-2009

by

Kristina Amanda Dick

A thesis submitted in partial fulfillment of the requirements for the degree of

Master of Science

in

Geography

Thesis Committee:

Andrew G. Fountain, Chair

Heejun Chang

Martin Lafrenz

Portland State University

2013 


\begin{abstract}
Glaciers respond to local climate changes making them important indicators of regional climate change. The North Cascades region of Washington is the most glaciated region in the lower-48 states with approximately $25 \%$ of all glaciers and $40 \%$ of the total ice-covered area. While there are many ongoing investigations of specific glaciers, little research has addressed the entire glacier cover of the region. A reference inventory of glaciers was derived from a comparison of two different inventories dating to about 1958. The different inventories agree within $93 \%$ of total number of glaciers and $94 \%$ of total icecovered area. To quantify glacier change over the past century aerial photographs, topographic maps, and geologic maps were used. In 1900 total area was about $533.89 \pm 22.77 \mathrm{~km}^{2}$ and by 2009 the area was reduced by $-56 \% \pm$ $3 \%$ to $236.20 \pm 12.60 \mathrm{~km}^{2}$. Most of that change occurred in the first half of the $20^{\text {th }}$ century, between 1900 and $1958,-245.59 \pm 25.97 \mathrm{~km}^{2}(-46 \% \pm 5 \%)$ was lost, followed by a period of stability/growth in mid-century $(-1 \% \pm 3 \%$ from 1958 $1990)$ then decline since the 1990 s $(-9 \% \pm 3 \%$ from $1990-2009)$. The centuryscale loss is associated with increasing regional temperatures warming in winter and summer; precipitation shows no trend. On a decadal time scale winter precipitation and winter and summer temperatures are important factors correlated with area loss. Topographically, smaller glaciers at lower elevations with steeper slopes and higher mean insolation exhibited greater loss than higher, gentler more shaded glaciers.
\end{abstract}




\section{Acknowledgements}

I would like to thank my adviser, Andrew G. Fountain for his guidance and support throughout this thesis project and to the committee members, Heejun Chang and Martin Lafrenz for their insights.

Support for this research is from the USGS via the Western Mountain Initiative (WMI).

I would also like to thank my S7 officemates for the valuable discussions of all things glacier. Last but not certainly not least, thanks to my family and my husband Aaron for all of their encouragement and support. 


\section{Table of Contents}

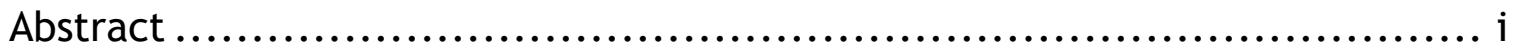

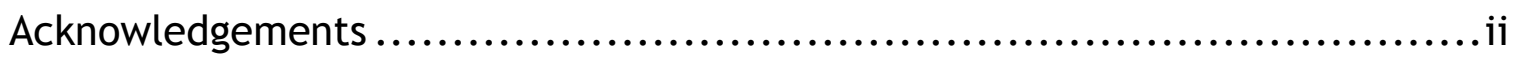

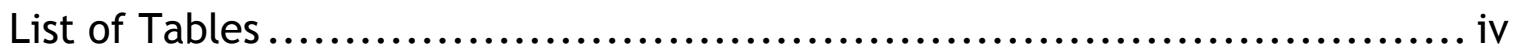

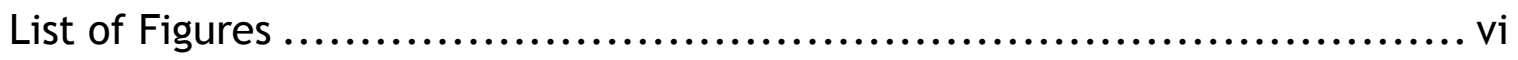

Chapter 1 - Introduction

Study Area.................................................................. 3

Previous Glacier Studies..............................................

Chapter 2 - Glacier Population Inventory

Introduction .......................................................... 10

Methods.............................................................. 10

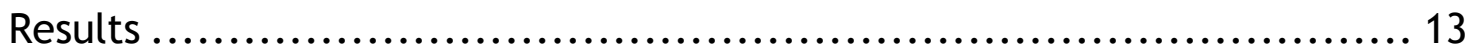

Analysis ............................................................... 19

Discussion \& Conclusions ............................................ 26

Chapter 3 - Temporal Glacier Inventory

Introduction ......................................................... 29

Methods.................................................................. 29

Results .............................................................. 33

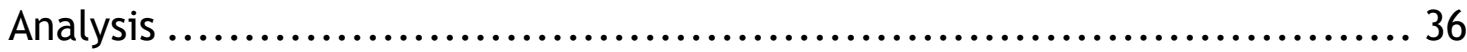

Discussion \& Conclusions ..................................................... 59

Chapter 4 - Climate and Topographic Analysis

Introduction ............................................................. 62

Methods................................................................... 63

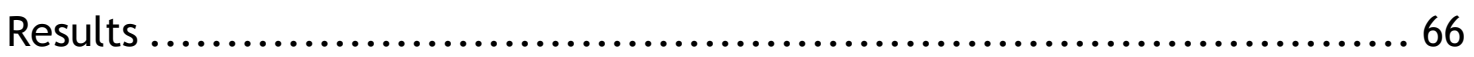

Discussion \& Conclusions ........................................... 81

Chapter 5 - Discussion and Conclusions ................................. 85

References.......................................................... 90

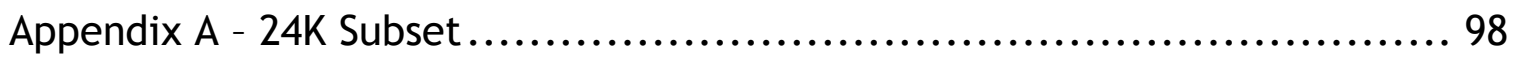

Appendix B - Temporal Glacier Inventories............................... 115

Appendix C - Climate Data ............................................ 128

Supplemental CD.................................................. 130 


\section{List of Tables}

Table 1 - Number and area of glaciers and perennial snowfields for each inventory...................................................... 20

Table 2 - Estimates of 'true' glaciers using a shear stress threshold for the $24 \mathrm{~K}$ inventory for the two sets of parameters (A) and (B)......... 25

Table 3 - Comparison of inventories using different methods.

Table 4 - Data sources and spatial coverage for glacier inventories and temporal data sets. ............................................... 30

Table 5 - Results of the temporal glacier inventories....................... 34

Table 6 - The results of the temporal glacier inventory displaying the number of glaciers in common for each combination of inventories, (A) refers to the glacier time series that has a 1900 glacier outline in common with each other inventories $(B)$ is the inventories that have $24 \mathrm{~K}$ outlines in common and $(C)$ is the inventories that have an aerial imagery year in common. ......... 37

Table 7 - Sample size of identical glaciers present in each inventory......... 38

Table 8 - Total area and uncertainty $\left(\mathrm{km}^{2}\right)$ for the two different groups of glaciers........................................................ 39

Table 9 - Fractional area change of total area of the same glaciers over the period 1900-2009 from group 1 and from 24K to 2009 from group 2 (Table 8)

Table 11 - A comparison of the topographic characteristics of each set of glaciers.

Table 12 - Area change over different time periods separated by areas greater/less than $0.1 \mathrm{~km}^{2}$ based on their initial area and by significant and insignificant changes, $\mathrm{n}$ is the number of glaciers, FAC is fractional area change.................................. 43

Table 13 - Analysis of glaciers with insignificant change. ................... 46

Table 14 - Overall area change from 1900-2009 summarized using fractional area change values for individual years......................... 48

Table 15 - Mount Baker temporal glacier area change data................... 51

Table 16 - Total and fractional area of all glaciers on Mount Baker. ........... 52

Table 17 - South Cascade Glacier area change from 1900-2009.............. 53

Table 18 - Mean monthly values of minimum and maximum air temperature (Tmin, Tmax), ${ }^{\circ} \mathrm{C}$, Precipitation (Precip), $\mathrm{mm}$, over the time period 1900-2009 derived from PRISM data.

Table 19 - Mann-Kendall (MK) and regression $\left(r^{2}\right)$ results for seasonal and annual temperature and precipitation trends for the time periods listed in the left hand column.

Table 21 - Results of the correlation analysis between glacier area change and climate variables.. ....................................... 72

Table 22 - Results of correlation analysis for the climate analysis divided into two groups for glaciers greater than and less than $0.1 \mathrm{~km}^{2} \ldots 73$ 
Table 23 - Results of correlation analysis for glacier area change and topographic variables.......................................... 74

Table 24 - Results of correlation analysis for the topographic analysis divided into two groups for glaciers greater than and less than $0.1 \mathrm{~km}^{2}$

Table 25 - Results of the multiple regression analysis. .................... 78

Table 26 - Precipitation (P) and Temperature (T) for seasonal and annual averages corresponding with periods of glacier area change for the entire North Cascades.. 


\section{List of Figures}

Figure 1 - North Cascades region with administrative boundaries and 24K glacier inventory (in black). ..................................... 4

Figure 2 - PRISM Climate averages for the State of Washington from 19712000. Precipitation is on the left and temperature is on the right. ..6

Figure 4- Map of the North Cascades glacier inventory (in black) with the North Cascades Park Complex outlined in green. ................. 15

Figure 5 - Number of glaciers in the 24K inventory per year of imagery acquisition.................................................... 16

Figure 6 - The frequency distribution of $24 \mathrm{~K}$ glaciers and perennial snowfields grouped by area.

Figure 7 - Topographic characteristics of the $24 \mathrm{~K}$ glaciers and perennial snowfields.

Figure 8 - Example of date checking the glacier outlines from 24K quadrangle glacier outline (on right) with more than one source year.

Figure 9 - The differences between how glaciers are demarcated in the Post and others (1971) and the 24K inventory....................... 20

Figure 10 - Comparison of Chickamin Glacier from 1939 (left) and 2004 (right). 31

Figure 11 - The ability to define a glacier outline is enhanced when color photography (right) is available compared to black and white (left)........................................................ 34

Figure 12 - Results of the two independent digitizing efforts. ............... 36

Figure 13 - Area change of the same glaciers for each temporal sequence

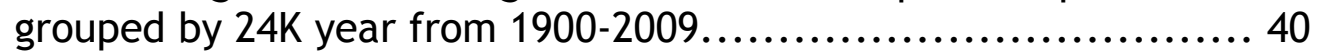

Figure 14 - Area change of identical glaciers for each temporal sequence grouped by $24 \mathrm{~K}$ year to 2009 .

Figure 15 - Fractional area change for different temporal area change groups.

Figure 16 - Uncertainty of all area change years compared to original area of the glacier.................................................... 47

Figure 17 - Overall fractional area change from 1900-2009 from Table 12. ... 49

Figure 18 - Fractional area change of the North Cascades using identical glaciers (by different $24 \mathrm{~K}$ year) compared to the partially overlapping estimate of glacier area change for the entire region (NOCA) from Figure 13.

Figure 19 - Area change for glaciers on Mount Baker (a) and South Cascade Glacier (b).

Figure 20 - Fractional area over the past century (a) for the total of all glaciers on Mount Baker, South Cascade and the total estimate of the North Cascades including Mount Baker. 
Figure 21 - Cumulative area sum for the North Cascades 24K (Chapter 2) with monitored glaciers indicated by points. ..................... 56

Figure 22 - Cumulative nest mass balance at South Cascade Glacier from 1958 - 2009................................................... 58

Figure 23 - Cumulative net mass balance of the North Cascades Glacier Climate Project monitored glaciers since 1984.................. 58

Figure 24 - Cumulative net mass balance of the North Cascades National

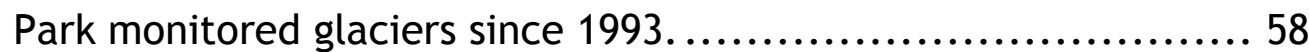

Figure 25 - Monthly PDO index values from 1900-2009 with a one year moving average (dark line)...................................... 63

Figure 26 - Annual and seasonal maximum temperatures and precipitation for the North Cascades.. .......................................... 70

Figure 27- Annual and seasonal temperature averages over the same periods of glacier area change in the entire North Cascades region.

Figure 28 - North Cascades fractional area change (a), monthly PDO index values with a one year running mean (dark black line) (b), and South Cascade annual net mass balance (c) to show potential relationships over the past century $\ldots . . \ldots \ldots \ldots \ldots \ldots \ldots \ldots \ldots \ldots \ldots . \ldots . \ldots 1$ 


\section{Chapter 1 - Introduction}

Glaciers are the result of accumulation of snow and mass loss primarily through melting and exist in locations where accumulation exceeds melting. The controlling variables of snow fall and melting, winter precipitation, summer air temperature vary over space and time. Over the decades, glaciers expand during cool wet periods and retreat during warm dry periods because glaciers respond to local climate changes they are important indicators of regional climate change. Mountain glaciers ( $\mathrm{km}$ in length) respond to changing climate conditions on a roughly decadal time scale (Johannesson and others, 1989), whereas smaller glaciers respond more quickly (Hoffman and others, 2007). The Intergovernmental Panel on Climate Change (IPCC) has used glaciers as an indicator of climate change since 1990 (Cooper and others, 2002). Glaciers affect alpine streamflow because water is stored upstream as snow/ice, and the timing of runoff is influenced by the percentage of glacier coverage (Fountain \& Tangborn, 1985). Downstream effects include alpine ecosystems that depend on glacial runoff (Hall \& Fagre, 2003), hydropower, and agricultural uses, and finally sea level rise. Between 1961 and 1998 alpine glaciers and ice caps contributed about $13 \mathrm{~mm}$ to global sea-level rise, approximately $20 \%$ of the total observed sea-level rise (Dyurgerov \& Meier, 2000, Dyurgerov and others, 2002).

Glaciers respond to large-scale variations in climate (McCabe \& Fountain, 1995, Hodge and others, 1998, Bitz \& Battisti, 1999, McCabe and 
others, 2000, Meier and others, 2003). The temporal variation in the climate of the western United States is influenced by several modes of atmospheric circulation that are characterized by different climate indices. The El-NiñoSouthern Oscillation (ENSO-SOI) acts on an interannual period, the average cycle lasts 6-18 months (Zhang and others, 1997). Acting on an interdecadal scale, the Pacific Decadal Oscillation (PDO) produces similar climate anomalies as the ENSO-SOI, although not as extreme (Munn, 2002, Mantua and others, 1997). Warm PDO phases are characterized by cool SSTs over the central North Pacific and warmer SSTs along the west coast, and cool PDO phases are produced by the opposite conditions. A warm phase PDO causes below-average snowpack and streamflow in the western United States, and a cool phase PDO causes an above average effect (Munn, 2002, Bitz \& Battisti, 1999, Mote, 2005). McCabe and Dettinger (2002) showed that PDO explains year to year variation in snowpack better than ENSO. The effects of climate variation on the western United States have wide reaching implications for water resources.

The purpose of studying the North Cascades is several fold. First, the region has the highest concentration of ice cover in the continental United States approximately 1,935 glaciers and perennial snowfields with an area of $288.3 \mathrm{~km}^{2}$ (Fountain and others, 2007b). Second, extensive historic data exists for a few glaciers in the region (NPS, USGS, NCGCP). My thesis provides a comprehensive examination of glacier change, and its magnitude and rate relative to these historic studies of single glaciers. 
My thesis initially compares a US Geological Survey topographic map (1:24000) glacier inventory compiled by cartographers to the Post and others (1971) inventory compiled by glaciologists to determine their similarity. If they are similar, I use the topographic attributes from the map inventory to characterize the glacier cover of the region. I then update the inventory with new temporal data to identify glacier area change with time. These changes are compared to climate and topographic variations to determine the important controlling factors.

This thesis is divided into five chapters, after the introduction and site description, there is a glacier population inventory followed by glacier temporal area change; in subsequent analysis of topography and climate and finally, discussions and conclusions are presented.

\section{Study Area}

The Cascades are a mountain range that extends from northern California to northern Washington. The North Cascades region, the focus of my study, is in Washington State and stretches from latitude $48^{\circ} \mathrm{N}$ to the Canadian Border at $49^{\circ} \mathrm{N}$ and between $122^{\circ} 30^{\prime}$ and $121^{\circ} 30^{\prime} \mathrm{W}$ for a total area of about $20,000 \mathrm{~km}^{2}$. The elevation ranges from less than $1,000 \mathrm{~m}$ to $3,285 \mathrm{~m}$ at the peak of Mount Baker. The North Cascades National Park Complex consists of the North Cascades National Park, Ross Lake Recreation Area, and the Lake Chelan National Recreation Area, and the Okanagan-Wenatchee National Forest and Mt. Baker-Snoqualmie National Forest. The landcover of the area consists of 
dense evergreen forest in the low-lying areas and alpine ecosystems and exposed rock with ice and snow in the upper elevations.

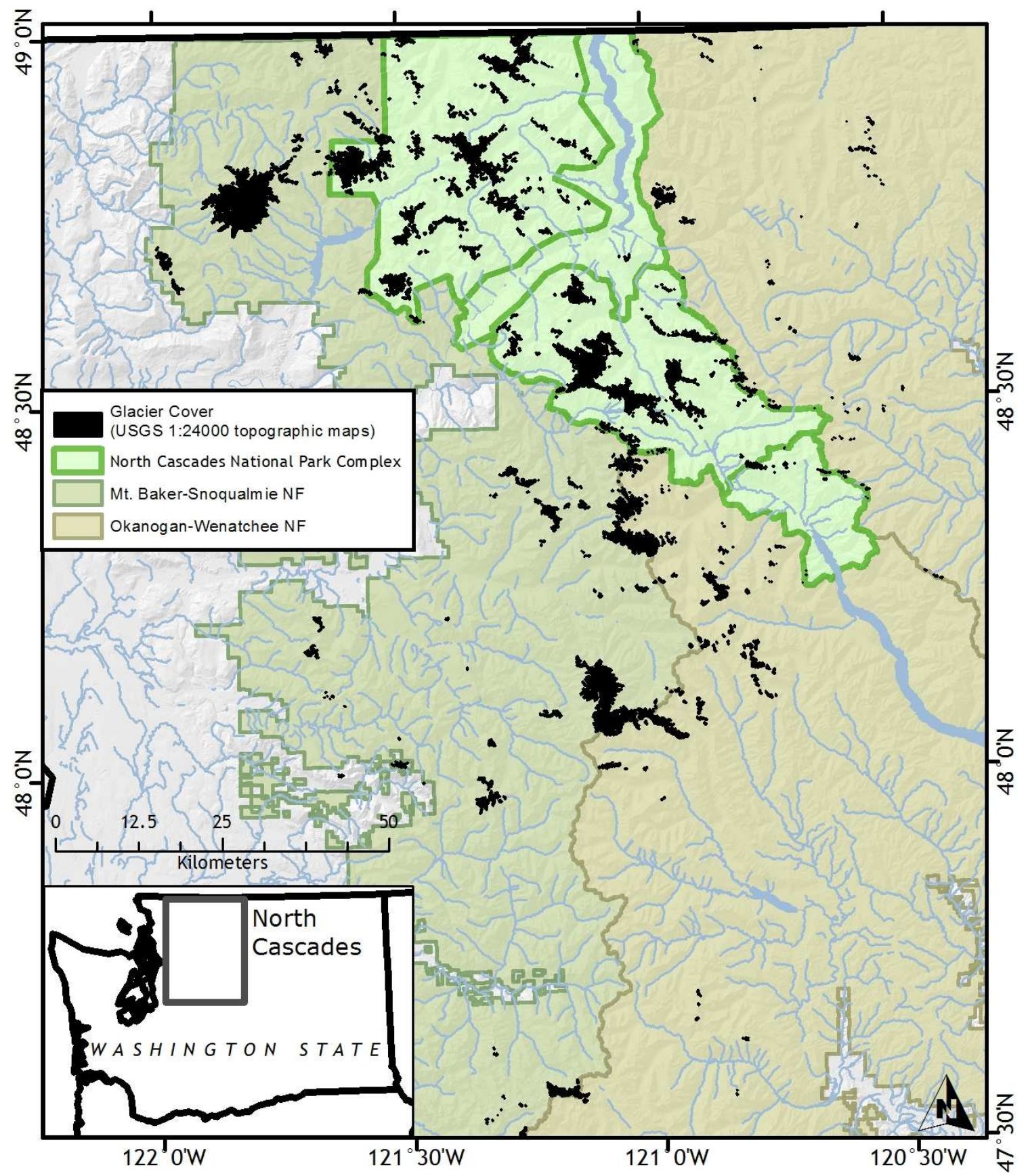

Figure 1 - North Cascades region with administrative boundaries and 24K glacier inventory (in black). 
The bedrock of the region consists of Paleozoic and Mesozoic sedimentary, intrusive and metamorphic rocks. About 40 million years ago the Cascade Magmatic Arc developed over the top of the mosaic, covering the older rocks with lava and ash and the volcanic peaks of Mount Baker and Glacier Peak formed (Haugerud \& Tabor, 2009).

Throughout the Pleistocene, the Cordilleran ice sheet and alpine glaciers shaped the topography of the North Cascades. Alpine glaciers formed cirques, arêtes and coalesced with the Cordilleran ice sheet through existing river channels and carving large U-shaped valleys. Throughout the Holocene, there have been several glacier advance events at $\sim 7 \mathrm{ka}$, about 2-3 ka and several small events over the past 700 years (Easterbrook, 1963). The last one was in the $13^{\text {th }}-20^{\text {th }}$ centuries and is known as the Little Ice Age.

In the spring and summer, high pressure dominates the North Pacific Ocean and brings dry, cool and stable air in a west/northwest direction. In the fall and winter, the Aleutian low-pressure cell moves south, pushing the high pressure further south, and the dominate wind direction changes to the west and southwest. The moist air from the ocean condenses and is orographically uplifted creating precipitation (Ruffner and others, 1985). The first barrier that forces orographic uplift is the Olympic Mountains and as the air masses move eastward they meet the Cascades Mountains. The majority of precipitation falls on the west side of the Cascades (Figure 2 ) and the east side is a rain shadow (Figure 2). 

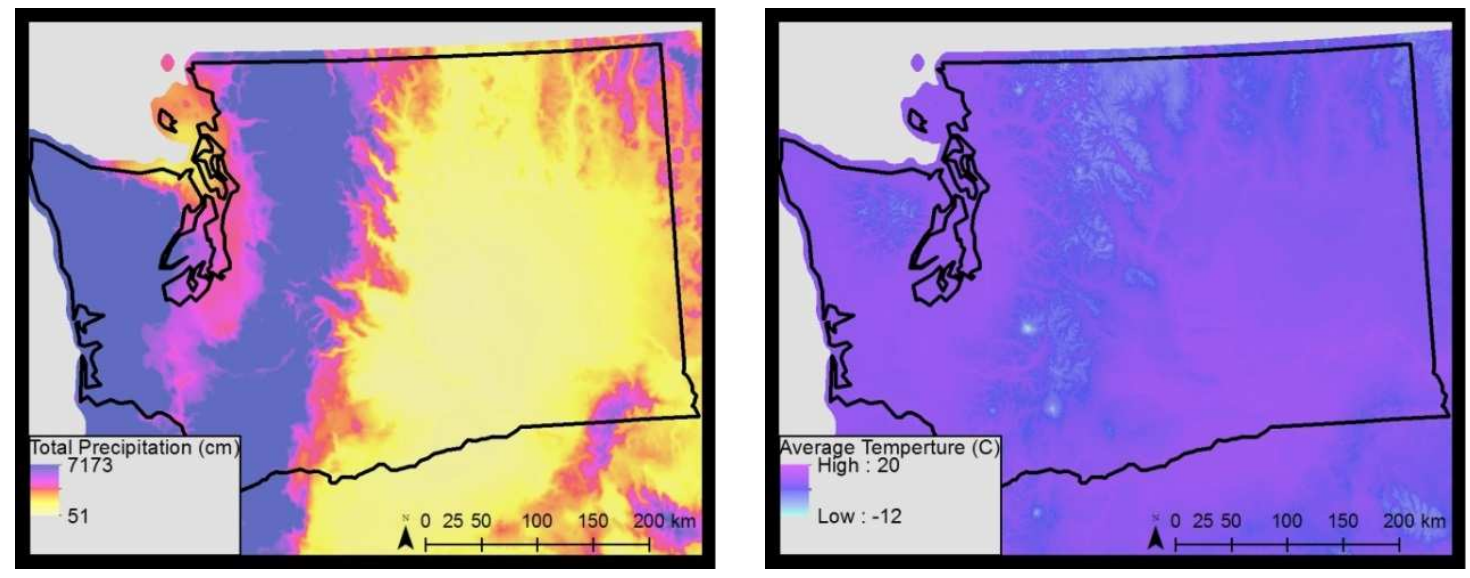

Figure 2 - PRISM Climate averages for the State of Washington from 1971-2000. Precipitation is on the left and temperature is on the right.

The North Cascades consists of several major watersheds, including the Skagit, Stehekin, Nooksak and Cascade rivers. Snow and ice melt are important contributors because runoff is highest when precipitation is low and temperatures are highest. Potential changes to the runoff regimes could have large reaching consequences for the hydroelectric power generation downstream. Glaciers delay the time of maximum seasonal runoff until later on in the summer (Fountain \& Tangborn, 1985). Runoff from glacier-free watersheds is controlled by precipitation, while glacierized watersheds are controlled by energy. This is important because glacierized watersheds produce more water during hot, dry periods. The inter-annual variability of runoff decreases with increasing fractional glacier cover, up to about $30-40 \%$ due to a buffering influence between ice-free and glacierized portions of the catchment (Moore and others, 2009). 


\section{Previous Glacier Studies}

The first published account of glaciers in the North Cascades was by I.C Russell when he recognized glaciers in the mountains of the North Cascades (Russell, 1897). The first glacier inventory of the North Cascades was subset of a general glacier inventory of the western United States and identified 519 features with a total area of $251.7 \mathrm{~km}^{2}$ (Meier, 1961). A comprehensive inventory of the North Cascades was completed by Post and others (1971) and included all glacial features greater than $0.1 \mathrm{~km}^{2}$. This inventory covers the entire North Cascades range from Snoqualmie Pass to the Canadian border. It identified 756 glaciers for a total area of $275 \mathrm{~km}^{2}$. Granshaw and Fountain (2006) updated the Post and others (1971) inventory within the North Cascades National Park Complex using 1998 aerial imagery (Granshaw \& Fountain, 2006) they used glacier outlines from the U.S Geological Survey (USGS) 1:24000 topographic maps dated to 1958 imagery because as a baseline because Post and others (1971) did not attempt to reproduce glacier shape accurately. The 1998 glacier extents were derived by modifying the mapped outlines using aerial imagery. They identified 321 glaciers in 1958 with a total area of $117.3 \pm$ $1.0 \mathrm{~km}^{2}$ and 316 glaciers in 1998 with a total area of $109.1 \pm 1.1 \mathrm{~km}^{2}$ for a total area change of $-7 \%$. In addition, they found that small glaciers lost relatively more area than larger glaciers. Other studies on Mount Baker provide an extensive time series of glacier change (Harper, 1993, Kovanen, 2003, Pelto, 1993, Fountain and others, 2007a). Mount Baker has a more maritime climate 
and is at a higher elevation than other glaciers in the North Cascades region and experiences more variability (Harper, 1993). Kovanen (2003) concluded that the glacier terminus fluctuations were related to PDO regime changes

The second longest glacier mass balance program in the world (since 1958) is located on South Cascade Glacier in the North Cascades. Between 1958 and 2003, the South Cascade Glacier has retreated about $0.6 \mathrm{~km}$ from its 1958 terminus position and the average net balance has been $-0.55 \mathrm{~m}$ water equivalent (Bidlake and others, 2007). The North Cascades National Park currently monitors four glaciers in the park complex starting in 1994 (Riedel \& Larrabee, 2011). These measurements include annual and seasonal mass balance. The North Cascades Glacier Climate Project (NCGCP) monitors net mass balance on eight glaciers, with two more glaciers added in 1994 (Pelto, 1988, Pelto, 2008).

Although surface mass balance measurements are most useful in understanding how glaciers are changing, they are a costly and labor intensive method (Fountain and others, 1997). Consequently, few glaciers can be measured. Aerial and satellite imagery provide a relatively inexpensive alternative to monitor many glaciers but at this time limited to area change assessment not mass balance. The use of a geographic information system (GIS) technology is an efficient way to create and update temporal glacier inventories (Mennis \& Fountain, 2001, Mool and others, 2001, Paul and others, 
2002, Granshaw \& Fountain, 2006). I utilize this this format to store and update the glacier inventory for the North Cascades. 


\section{Chapter 2 - Glacier Population Inventory}

\section{Introduction}

The purpose of this chapter is to test the fidelity of a glacier inventory derived from published topographic maps compiled by cartographers against an inventory compiled by glaciologists (Post and others, 1971). I address two questions:

1) If Post and others (1971) is the 'true' inventory, then how accurate are the features derived from topographic maps?

2) If there is a mismatch between the inventories are there any obvious remedies?

Comparison between these two inventories is important because Post and others (1971) do not contain detailed topographic information. However, if they correspond, then the topographic data from the maps can be used to characterize the population attributes of the glaciers and perennial snowfields to create a template for comparison of future changes. Granshaw and Fountain (2006) addressed the same questions, however their inventory was limited to the North Cascades Park Complex which is a subset of the full inventory of the North Cascades. I reexamined the questions using the full inventory.

\section{Methods}

Glacier outlines were derived from U.S. Geological Survey (USGS) 7.5 minute topographic maps at the scale of 1:24000 which are based on aerial imagery acquired in different years. This dataset is abbreviated as ' $24 \mathrm{~K}$ '. Glaciers are depicted on the maps with blue outlines and blue contour lines 
with a white background. We assume that the cartographers only mapped features they deemed perennial. Although I refer to the mapped features as 'glaciers', in fact they are a combination of glaciers and perennial snowfields. The digital glacier outlines were obtained from the USGS, and compared against the digitally scanned maps and corrections made (Fountain and others, 2007b). The attributes include 'official' glacier name, USGS quadrangle name, latitude, longitude, area, topographic characteristics and photography year. The topographic characteristics for each feature were calculated by overlaying the glacier outline on a $10 \mathrm{~m}$ digital elevation model (DEM) and calculating the zonal statistics using ArcGIS (ESRI, 2012). The calculated topographic characteristics included mean aspect, and mean, minimum, and maximum of both slope (degrees) and elevation (meters).

The inventory by Post and others (1971) is based on vertical aerial photographs at a scale of 1:38000 and were acquired over the North Cascades in late summer 1958. Oblique photographs, USFS topographic maps, and personal observations supplemented the vertical aerial photographs. The features were then drawn on maps and their location, latitude/longitude to the nearest minute, was calculated. Additional attributes of each glacier included area, length, accuracy, nature of terminus and activity. Post and others (1971) defined a glacier as 
"any perennial ice that has an area of at least $0.10 \mathrm{~km}^{2}$. Included are (1) active glaciers, (2) ice patches derived from direct snow accumulation, wind drift, or snow avalanches, without regard for evidence of glacier flow, and (3) relict ice from former active glaciers. Ice patches derived from avalanching of ice from hanging glaciers are considered to be part of the parent glacier."

Estimating uncertainty in glacier area is important for defining the significance of area change. Three types of uncertainty are identified: position, digitizing, and interpretation (Sitts and others, 2010). Positional uncertainty is the horizontal error of the image or map to the surface topography. The digitizing uncertainty is the deviation of the digitized outline from the actual glacier perimeter presuming it is sharp and easy to follow. Interpretation uncertainty is caused by shadows, debris-covered ice, and seasonal snow that mask the true outline of the glacier. The total uncertainty $\left(\mathrm{km}^{2}\right)$ is the root sum of squares of position (P), digitizing (D), and interpretation (I) uncertainties.

$$
U_{\text {total }}=\sqrt{P^{2}+D^{2}+I^{2}}
$$

For the $24 \mathrm{~K}$ maps, the positional uncertainty is $12.2 \mathrm{~m}$, the relative accuracy of 95\% of the points that fall within that range (Fountain and others, 2007b), however I assume the value is zero because any shifting in the horizontal accuracy will not affect glacier area. Although, the digitizing uncertainty is considered to be the width of the line on the $24 \mathrm{~K}$ maps, $2.4 \mathrm{~m}$, (Granshaw \& Fountain, 2006) that value results in a conservative overall uncertainty and I used the positional uncertainty value, $12.2 \mathrm{~m}$, as the digitizing uncertainty. 
This digitizing uncertainty is evaluated using the method developed by Ghilani (2000) and applied by Hoffman and others (2007). The Ghilani method (2) provides a less conservative, more realistic uncertainty value than applying a buffer because it ignores the covariance of the error between vertices.

$$
D=\sqrt{A} \times D U \times \sqrt{2}
$$

where $A$ is glacier area, $\mathrm{km}^{2}$, and $D U, \mathrm{~km}$, is the linear digitizing uncertainty value. The value of $D$ is used in equation 1 to calculate overall uncertainty. The interpretation uncertainty is unknown for the $24 \mathrm{~K}$ dataset. Post and others (1971) estimate the accuracy in two categories, category 1 is excellent ( 95 percent) and category 2 is fair ( 5 percent). I calculated uncertainty based on those two categories estimating that the uncertainty for category 1 is 5 percent times glacier area and for category 2 is 95 percent.

\section{Results}

The glaciers in the $24 \mathrm{~K}$ inventory are found from $48.25^{\circ}$ to $49^{\circ} \mathrm{N}$ at the Canadian border, and from $120.42^{\circ} \mathrm{W}$ to $121.99^{\circ} \mathrm{W}$ (Figure 3). Based on the map collar the year of imagery acquisition is defined for that specific quadrangle. The largest number of glaciers (37\%) is from 1958 aerial photography (Figure 4), with the remaining features over a 28 year period from 1957 to 1985 . From these maps a total of 1935 glaciers are identified, of which 102 are named, with a total area of $288.3 \pm 12.5 \mathrm{~km}^{2}$. The area of individual glaciers ranges from $0.0004 \mathrm{~km}^{2}$ (unnamed) to $6.83 \mathrm{~km}^{2}$ (Coleman Glacier) on Mount Baker, with an average of $0.15 \mathrm{~km}^{2}$ and a median of $0.03 \mathrm{~km}^{2}$. The 
frequency distribution of glacier area is highly skewed towards small glaciers (Figure 5). Most of the ice-cover spans $1500 \mathrm{~m}$ to $2500 \mathrm{~m}$ reaching a maximum of about $2000 \mathrm{~m}$. Relative to the total area of the entire region, ice covers most of the elevations higher than about $2400 \mathrm{~m}$ (Figure 6a). The total range in glacier elevation is between $593 \mathrm{~m}$ to $3282 \mathrm{~m}$ at the summit of Mount Baker. The average elevation of the glaciers is $1948 \mathrm{~m}$ with a median of $1972 \mathrm{~m}$ (Figure 6b). Glacier slope is steep averaging $29.7^{\circ}$ with a median of $29.2^{\circ}$ (Figure 6c). The glaciers face all directions, with most in the $\mathrm{N}$ and NE direction (Figure 6d) as one would expect in the northern hemisphere. The 'typical' glacier for the North Cascades may be characterized as small, 0.03 $\mathrm{km}^{2}$, facing NNE at an elevation of $1972 \mathrm{~m}$ with a slope of $29.2^{\circ}$. 


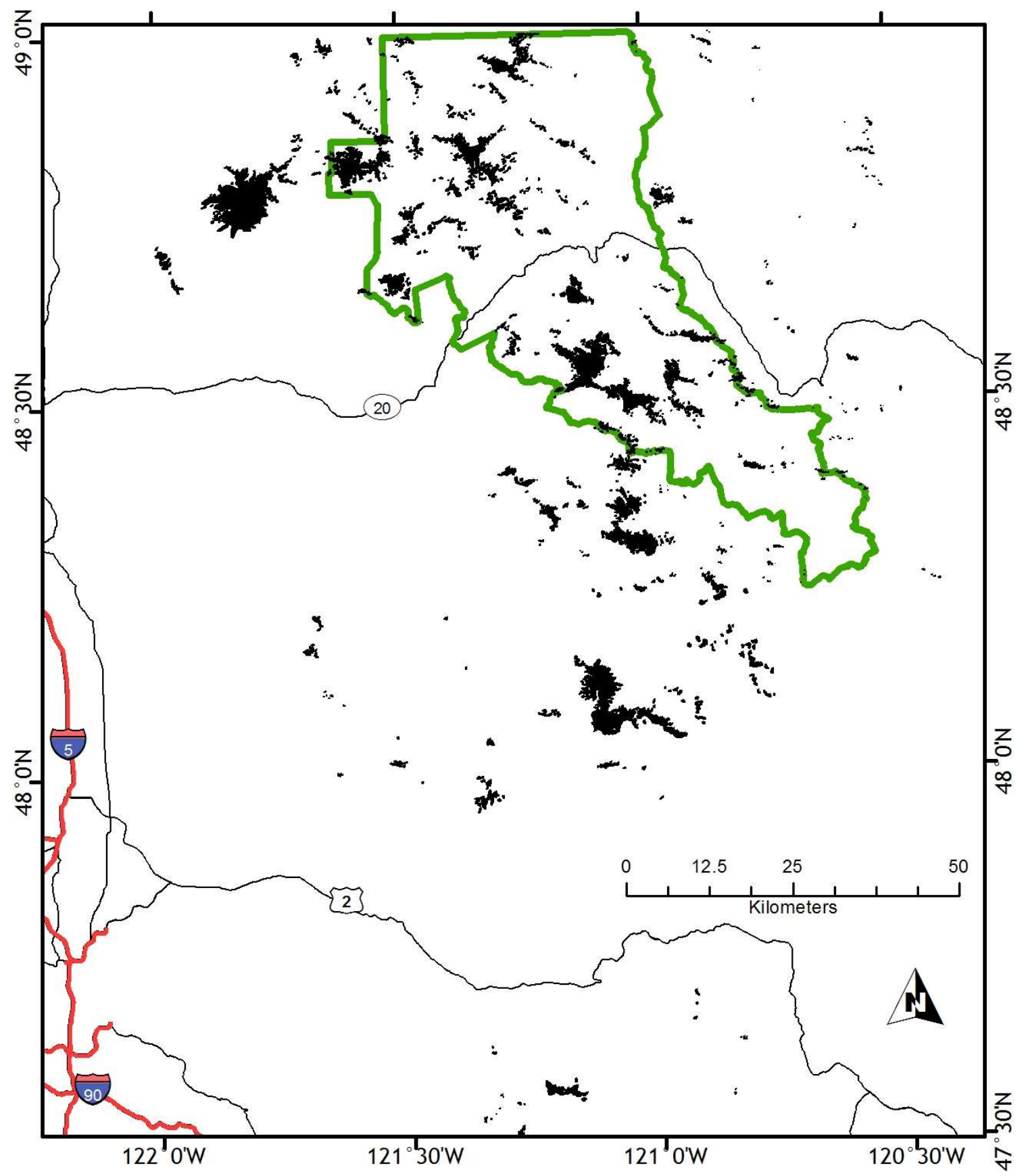

Figure 3- Map of the North Cascades glacier inventory (in black) with the North Cascades Park Complex outlined in green. Major highways are shown for reference. 


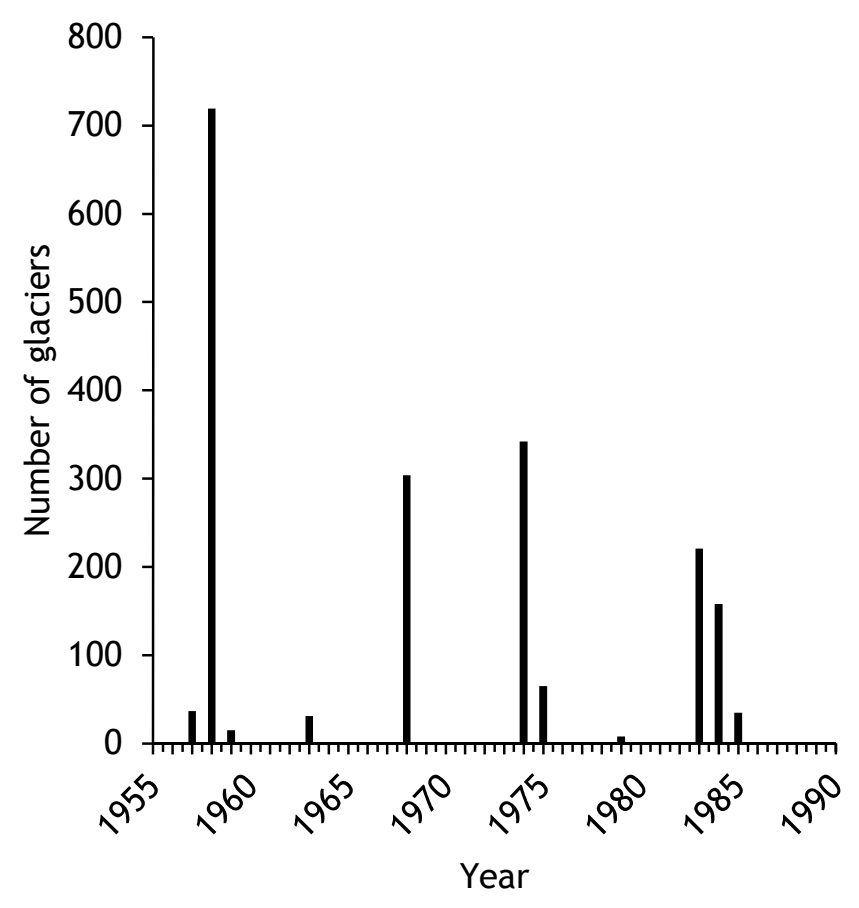

Figure 4 - Number of glaciers in the $24 \mathrm{~K}$ inventory per year of imagery acquisition.

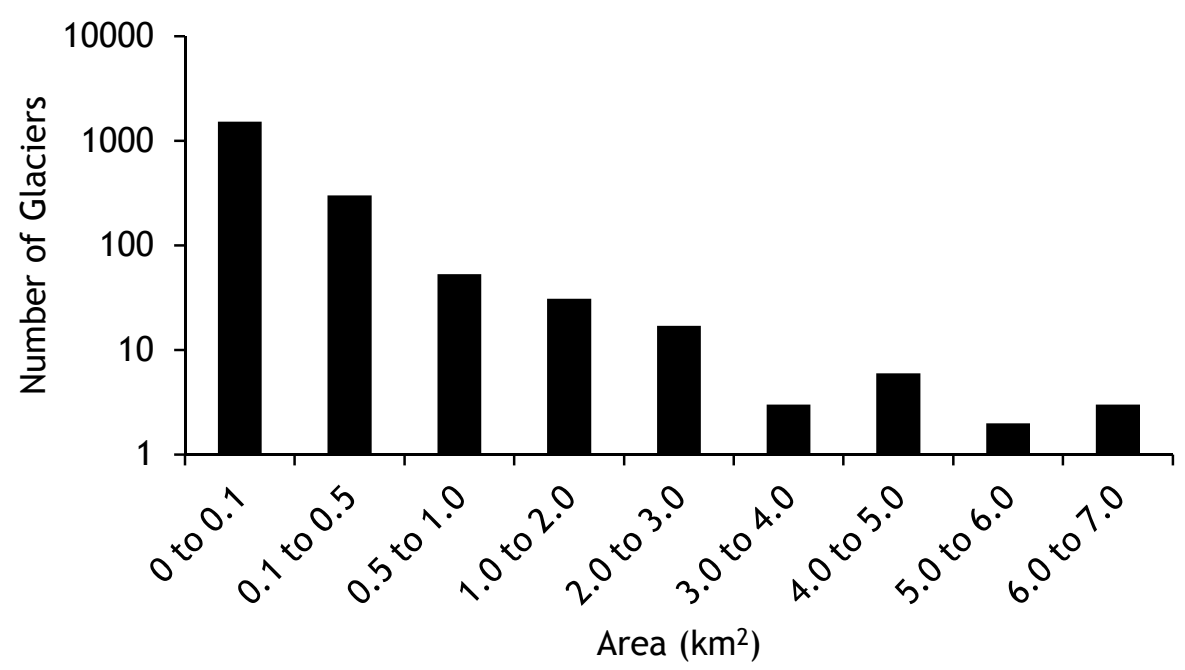

Figure 5 - The frequency distribution of 24K glaciers and perennial snowfields grouped by area. The maximum value for each area range is included in that group. 

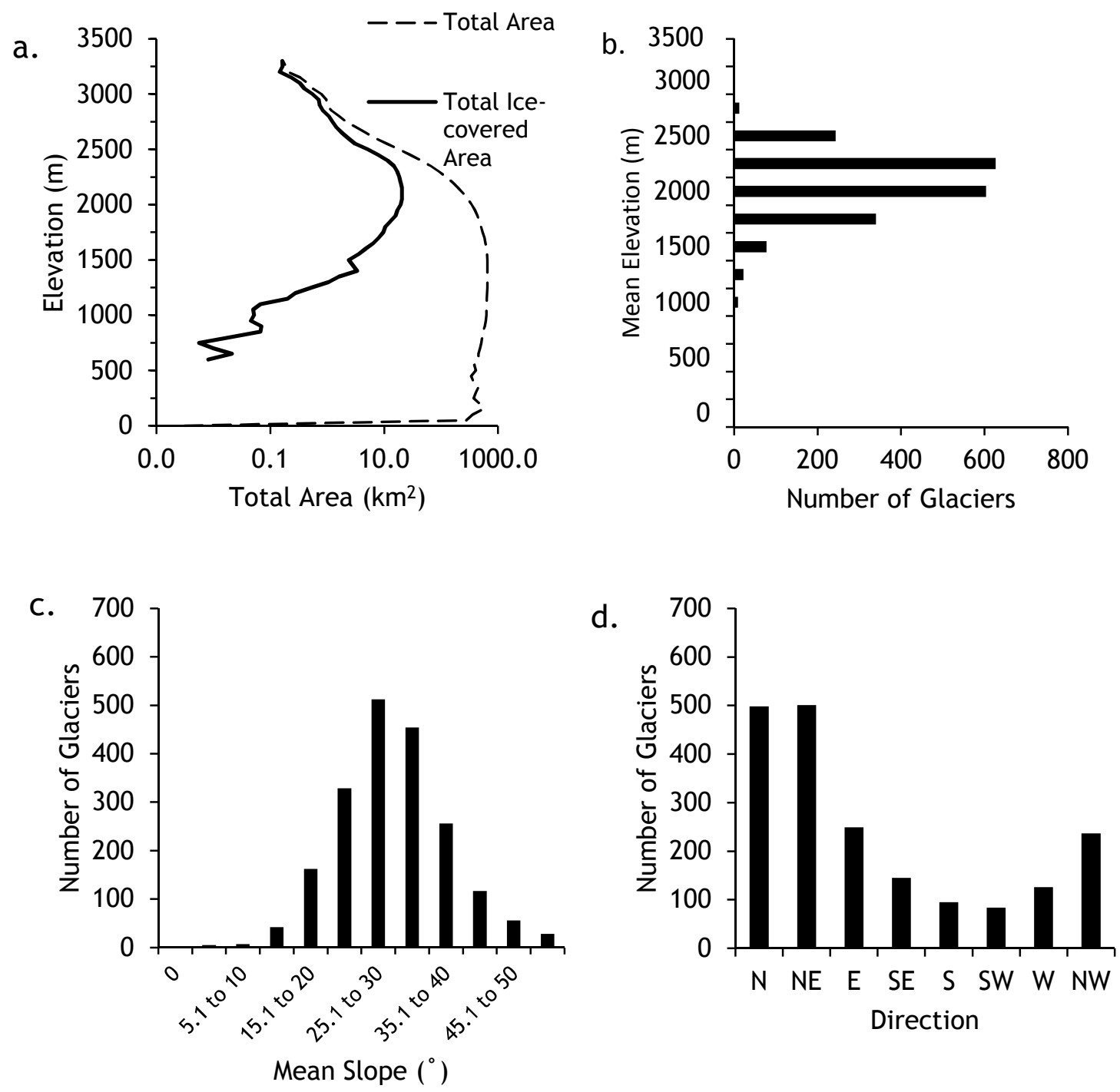

Figure 6 - Topographic characteristics of the 24K glaciers and perennial snowfields. (a) elevation of the entire region and all ice-covered areas at $50 \mathrm{~m}$ contour intervals; (b) mean elevation for each feature grouped by $100 \mathrm{~m}$ intervals; (c) mean slope for each feature grouped by 5 degrees; (d) mean aspect grouped by 8 directions $(\mathrm{N}=0-22.5 ; \mathrm{NE}=22.5-67.5 ; \mathrm{E}=67.5-112.5$; $\mathrm{SE}=112.5-157.5 ; \mathrm{S}=157.5-202.5 ; \mathrm{SW}=202.5-247.5 ; \mathrm{W}=247.5-292.5 ; \mathrm{NW}=292.5-$ 337.5; and $\mathrm{N}=337.5-360$ ).

As mentioned, the $24 \mathrm{~K}$ quadrangles were originally mapped by the USGS using aerial photographs acquired over different years. Although the map collar 
may indicate that the original map was 'revised' to a more modern date, the glacier outlines were not and date to the original photographs. I verified the image year for all 24K maps within the North Cascades using single frame aerial photographs from the USGS EarthExplorer (www.earthexplorer.usgs.gov) (Figure 7). The 24K maps have been recently revised in a digital format, however none of the glacier outlines were updated (Cooley and others, 2011).

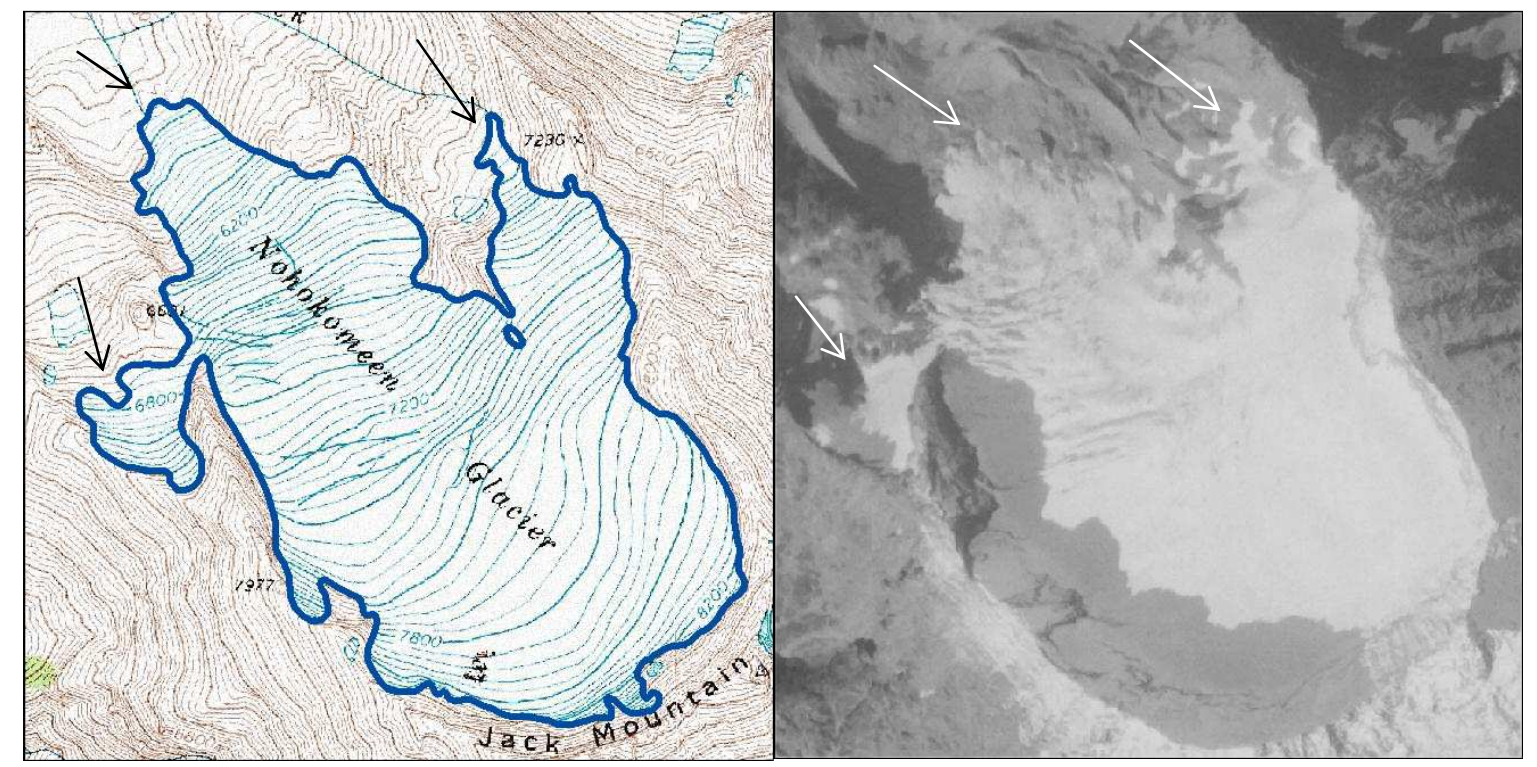

Figure 7 - Example of date checking the glacier outlines from 24K quadrangle glacier outline (on right) with more than one source year. Image on left is from 1968, and the arrow points to obvious similarities in the features.

The Post and others (1971) inventory reported 756 glaciers for a total area of $275.2 \pm 19.5 \mathrm{~km}^{2}$. However, 14 of the 756 glaciers found on their inventory map were not included in their report tabular data, Post estimated the total area of these 14 features to be less than $1.0 \mathrm{~km}^{2}$. The reason given is that they were discovered too late to be included in the 1971 report. The 
glacier shapes on the paper maps included in the report were highly generalized.

\section{Analysis}

The timing of the aerial photography was quite different for the two inventories. The Post and others (1971) images were taken solely in 1958, whereas only about $1 / 3$ of the images used in the $24 \mathrm{~K}$ were taken in 1958 and the rest over the 28 year range from 1957 - 1985. However, this is not an important difference because the 1957 - 1985 period was a time of glacier stability (Chapter 3), therefore difference between the inventories should not be caused by differences in imagery dates.

The numbers of glaciers between inventories are quite different. The total number of glaciers in the $24 \mathrm{~K}$ inventory is almost three times that of Post and others (1971) but the area is only $4 \%$ larger (Table 1 ). Most of the difference $(+79 \%$ number, $-13 \%$ area $)$ is caused by the smallest glaciers, less than or equal to $0.1 \mathrm{~km}^{2}$. The glaciers between 0.1 and $0.5 \mathrm{~km}^{2}$ explains a further $+16 \%$ number $(+21 \%$ area) of the difference. Clearly, the major difference between inventories is the identification and inclusion of small glaciers. The remaining difference in number $(5 \%)$ is due to how large continuous ice masses are divided into individual glaciers (Figure 8). 
Table 1 - Number and area of glaciers and perennial snowfields for each inventory. 'Post' refers to the Post and others (1971) inventory; 24K refers to the entire $24 \mathrm{~K}$ inventory in the North Cascades, the 24k minus Post is the difference between those two inventories. The $24 \mathrm{~K}$ subset is included for comparison purposes also. Only glaciers equal to $0.1 \mathrm{~km}^{2}$ included in the Post inventory. Largest number in each area range is included in that group.

Additional overall uncertainty values were added to the Post and 24K subset datasets due to additional information, and therefore the sum area uncertainty will not add up down the row.

\begin{tabular}{|c|c|c|c|c|c|c|c|c|}
\hline \multirow[b]{2}{*}{$\begin{array}{l}\text { Area } \\
\left(\mathrm{km}^{2}\right)\end{array}$} & \multicolumn{2}{|r|}{ Post } & \multicolumn{2}{|r|}{$24 K$} & \multicolumn{2}{|c|}{ 24K minus Post } & \multicolumn{2}{|c|}{ 24K Subset } \\
\hline & $n$ & $\begin{array}{l}\text { Area } \\
\left(\mathrm{km}^{2}\right)\end{array}$ & $n$ & $\begin{array}{l}\text { Area } \\
\left(\mathrm{km}^{2}\right)\end{array}$ & $n$ & $\begin{array}{l}\text { Area } \\
\left(\mathrm{km}^{2}\right)\end{array}$ & $n$ & $\begin{array}{l}\text { Area } \\
\left(\mathrm{km}^{2}\right)\end{array}$ \\
\hline$\leq 0.1$ & 411 & $41.1 \pm 4.0$ & 1519 & $37.9 \pm 5.5$ & 1108 & -3.2 & 287 & $15.3 \pm 1.7$ \\
\hline $0.1-0.5$ & 222 & $60.1 \pm 4.8$ & 301 & $59.8 \pm 3.4$ & 97 & 8.7 & 288 & $60.1 \pm 3.3$ \\
\hline $0.5-1.0$ & 58 & $46.4 \pm 3.2$ & 53 & $38.2 \pm 1.2$ & -15 & -9.2 & 64 & $46.6 \pm 1.4$ \\
\hline $1.0-2.0$ & 28 & $39.9 \pm 2.0$ & 31 & $40.8 \pm 0.9$ & -4 & -5.1 & 31 & $42.4 \pm 0.9$ \\
\hline $2.0-3.0$ & 8 & $21.1 \pm 1.1$ & 17 & $42.8 \pm 0.7$ & 9 & 22.7 & 12 & $29.3 \pm 0.5$ \\
\hline $3.0-4.0$ & 5 & $16.8 \pm 0.8$ & 3 & $10.7 \pm 0.1$ & -3 & -9.1 & 8 & $28.8 \pm 0.4$ \\
\hline $4.0-5.0$ & 5 & $22.4 \pm 1.1$ & 6 & $27.6 \pm 0.3$ & 2 & 10.2 & 4 & $19.3 \pm 0.2$ \\
\hline $5.0-6.0$ & 4 & $20.8 \pm 1.0$ & 2 & $10.7 \pm 0.1$ & -3 & -15.1 & 2 & $10.5 \pm 0.1$ \\
\hline $6.0-7.0$ & 1 & $7.0 \pm 0.4$ & 3 & $19.9 \pm 0.2$ & 2 & 12.9 & 1 & $6.8 \pm 0.1$ \\
\hline $\begin{array}{l}\text { Sum: } \\
\text { Average: }\end{array}$ & 756 & $\begin{array}{c}275.6 \pm 21.7 \\
0.4\end{array}$ & 1935 & $\begin{array}{c}288.4 \pm 12.5 \\
0.15 \\
0.03\end{array}$ & 1193 & 12.7 & 697 & $\begin{array}{c}259.1 \pm 10.4 \\
0.37 \\
0.12\end{array}$ \\
\hline
\end{tabular}
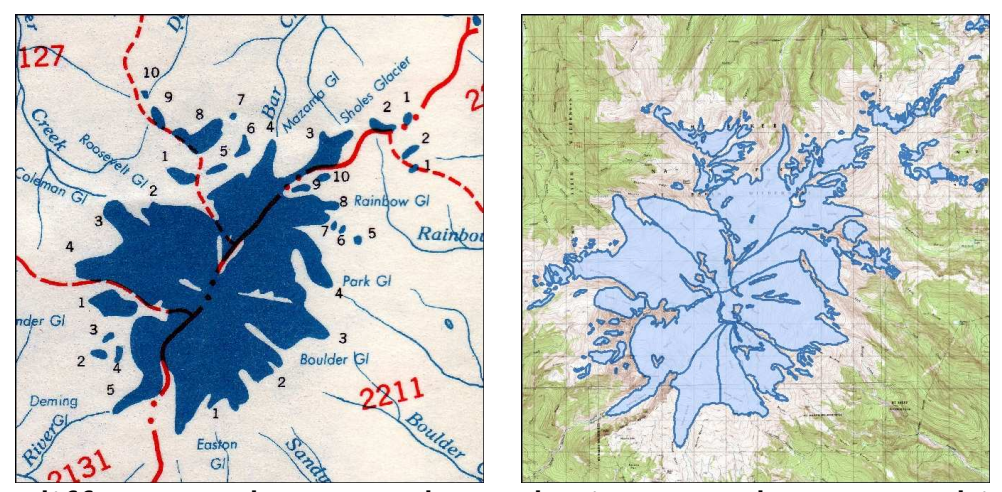

Figure 8 - The differences between how glaciers are demarcated in the Post and others (1971) and the 24K inventory. On the left Post and others (1971) do not clearly identify glacier outlines on Mount Baker, the glaciers were numbered implying a division. On the right the derived glaciers clearly show the outlines that are included in the $24 \mathrm{~K}$ topographic map. There are 31 glaciers on the left and 104 glaciers on the right with the main difference being the number of small glaciers. 
To reconcile the inventories presuming that Post and others (1971) correctly identified glacial features, the $24 \mathrm{~K}$ inventory is filtered to estimate the number of 'true' glaciers using two methods. First, I use an area threshold, common to many inventories (Basagic \& Fountain, 2011, Granshaw \& Fountain, 2006, Raub and others, 2006, Spicer, 1986, Paul and others, 2009, Abermann and others, 2009, DeBeer \& Sharp, 2007) and secondly a shear stress threshold (Granshaw \& Fountain, 2006, Basagic \& Fountain, 2011).

Post and others (1971) identified glacial features greater than $0.1 \mathrm{~km}^{2}$. To match Post and others (1971) the $24 \mathrm{~K}$ inventory was filtered to remove all features less than $0.1 \mathrm{~km}^{2}$ resulting in 416 glaciers with a total area of $250.4 \pm$ $6.96 \mathrm{~km}^{2}$ (Table 1). This is closer to the Post and others (1971) inventory of 756 glaciers with $9 \%$ less area $\left(25.18 \mathrm{~km}^{2}\right)$. However, the difference in the number of glaciers is huge $\sim 326(44 \%)$ fewer than found in Post and others (1971). To explore this more closely, I compared each glacier in Post and others (1971) to its mirror glacier in the full $24 \mathrm{~K}$ inventory to track correspondence between inventories. The Post and others (1971) map was digitally scanned and overlaid on the $24 \mathrm{~K}$ maps. The differences between the unique identifiers in Post and others (1971) and the $24 \mathrm{~K}$ is problematic because unique identifier (RECNO) in the $24 \mathrm{~K}$ inventory is based on one polygon equals one glacier, whereas the unique identifier (Basin ID) in Post and others (1971) is based on hydrology and drainage divides which provides most of the boundaries between glaciers. That is to say, Post and others (1971) grouped glaciers according to watersheds. To 
convert from RECNO to Basin ID any multi-part glaciers from the $24 \mathrm{~K}$ were assigned to one Basin ID, and any glaciers that spanned more than one Basin ID were split apart. Any glacier in the $24 \mathrm{~K}$ that could not be assigned to a Post identified glacier was deleted. The resulting inventory is hereafter referred to as the ' $24 \mathrm{~K}$ subset'. In the end, 711 glaciers from the $24 \mathrm{~K}$ were recombined into 697 glaciers $\left(259.1 \pm 8.6 \mathrm{~km}^{2}\right)$ common to both inventories using the Basin ID classification of Post and others (1971) (Table 1). The difference is 59 fewer 24K subset glaciers $\left(16.5 \mathrm{~km}^{2}\right)$ than Post and others (1971). Consequently, 1224 glaciers $\left(34.08 \mathrm{~km}^{2}\right)$ from the $24 \mathrm{~K}$ inventory, do not match Post and other's (1971), and all are smaller than $0.5 \mathrm{~km}^{2}$ with most (1175 or 61\%) smaller than $0.1 \mathrm{~km}^{2}$.

Seventy-two glaciers $\left(8.05 \mathrm{~km}^{2}\right)$ identified in the Post and others (1971) inventory were not found in the $24 \mathrm{~K}$ inventory, 11 of which were identified by Granshaw and Fountain (2006) as glaciers within the North Cascades Park Complex. A visual inspection of all 72 features against aerial photography of that period indicates that the 11 features identified by Granshaw and Fountain (2006) are indeed glacial, and are included in the $24 \mathrm{~K}$ subset above since their outlines were digitized by Granshaw and Fountain (2006). Of the remaining 61 glaciers, 32 glaciers $\left(4.4 \mathrm{~km}^{2}\right)$ could not be found due to the mis-match of the $24 \mathrm{~K}$ to the coarser scale paper map of Post; 29 features were determined to be glacial with a total area of $3.5 \mathrm{~km}^{2}$. The 32 missing glaciers from Post with an area of $4.4 \mathrm{~km}^{2}\left( \pm 16, \pm 2.2 \mathrm{~km}^{2}\right)$ adds to the uncertainty of Post and others 
(1971) while the 29 missing glaciers from the $24 \mathrm{~K}$ dataset $\left( \pm 15, \pm 1.75 \mathrm{~km}^{2}\right)$ adds to the uncertainty of the $24 \mathrm{~K}$ subset.

The $24 \mathrm{~K}$ subset shows that 287 glaciers are smaller than $0.1 \mathrm{~km}^{2}$, and these glaciers are identified in Post and others (1971) who claimed a $0.1 \mathrm{~km}^{2}$ threshold. Presumably, Post included these small glaciers and if the area is rounded to $0.1 \mathrm{~km}^{2}$. To correct the $24 \mathrm{~K}$ inventory for Post and others (1971) suspected inclusion of these small glaciers $\left(<0.1 \mathrm{~km}^{2}\right)$, I subtract the glaciers less than or equal to $0.1 \mathrm{~km}^{2}, 1519$, from the total 1935 (Table 1) and add back the 287 , resulting in $703\left(265.8 \mathrm{~km}^{2}\right)$, a value close to both the Post and others (1971) of $756 \pm 16\left(275.6 \pm 21.7 \mathrm{~km}^{2}\right)$ and to the $24 \mathrm{~K}$ subset of $697 \pm 15(259.1 \pm$ $\left.10.4 \mathrm{~km}^{2}\right)$.

The comparison of the $24 \mathrm{~K}$ and Post and others (1971) inventory revealed differences in both number and area. By correcting the $24 \mathrm{~K}$ by eliminating the small glaciers that Post did not count as glaciers, and adding back the small glaciers that Post did count, the result of 703 glaciers is only 39 (7\%) smaller than Post, and the area $265.8 \mathrm{~km}^{2}$ is only $9.8 \mathrm{~km}^{2}(4 \%)$ smaller. Therefore, once the counting methods are corrected for the differences in approach the two inventories are very similar.

A more process-based way to define a glacier is to infer movement. 'True' glaciers are defined as perennial snow and ice that moves (Cuffey \& Paterson, 2010). The threshold for glacier movement is whether the critical shear stress for ice, $10^{5} \mathrm{~Pa}$ (Cuffey \& Paterson, 2010) is achieved. This 
approach provides a more objective classification rather than the arbitrary area threshold. The shear stress at the base of the glacier is defined as

$$
\tau_{b}=\rho_{i} g h \sin \gamma
$$

where $\rho_{i}$ is ice density $\left(900 \mathrm{~kg} \mathrm{~m}^{-3}\right), \mathrm{g}$ is gravitational acceleration $\left(9.81 \mathrm{~m} \mathrm{~s}^{-2}\right)$, $h$ is ice thickness $(m)$, and $\gamma$ is the ice surface slope.

Surface slope is a topographic characteristic already derived for all $24 \mathrm{~K}$ glaciers and I use the maximum slope of all grid cells as a liberal estimate of slope for each feature. To estimate volume, I use the scaling relationship between area and volume (Chen \& Ohmura, 1990, Bahr and others, 1997) of the form,

$$
V=\propto A^{\beta}
$$

where $V$ is glacier volume $\left(\mathrm{km}^{3}\right), \alpha$ and $\beta$ are constants, and $A$ is the glacier area $\left(\mathrm{km}^{2}\right)$. The average thickness of the feature $\langle h>$, is estimated by dividing the volume by the surface area,

$$
<h>=\propto A^{\beta-1}
$$

The $\alpha$ and $\beta$ are scaling parameters that can be determined from empirical data (Chen \& Ohmura, 1990). I applied two different sets of scaling parameters from Chen and Ohmura (1990) 'Cascade and other areas' (A) $\propto=30.83$ and $\beta=1.406$ and the scaling parameters for 'Cascade, small glaciers' $(B), \alpha=21.35$ and $\beta=1.145$. Results are summarized in Table 2 . 
Table 2 - Estimates of 'true' glaciers using a shear stress threshold for the $24 \mathrm{~K}$ inventory for the two sets of parameters $(A)$ and $(B)$. The Post and others (1971) total inventory values are included for comparison.

\begin{tabular}{l|rc}
\hline \multicolumn{1}{c|}{ Inventory Name and Filter } & Number & Area $\left(\mathrm{km}^{2}\right)$ \\
\hline 24K - Scaling Parameters (A) & 334 & $240.2 \pm 6.21$ \\
24K - Scaling Parameters (B) & 601 & $259.7 \pm 8.04$ \\
\hline Scaling Parameters (B) & 1050 & $277.5 \pm 10.2$ \\
Shear Stress threshold $0.8 \times 10^{5}$ & & \\
Scaling Parameters (B) & 753 & $267.4 \pm 8.88$ \\
Shear Stress threshold 0.925 x 105 & & \\
\hline Post and others (1971) & 756 & $275.6 \pm 21.7$
\end{tabular}

The different scaling parameters produce quite different results and both underestimate the population compared to the entire Post and others (1971) inventory. The results of scaling parameters (-B-) resulted in a match of $81 \%(601)$ of the number of glaciers and $94 \%\left(258.72 \mathrm{~km}^{2}\right)$ of total area. With the uncertainty of Post and others (1971) overlapping the (-B-) estimate of area. To improve the match I adjusted the value of shear stress to gain a better match of both area and glacier number. Using scaling parameters (-B-) and reducing the critical shear stress to $0.925 \times 10^{5} \mathrm{~Pa}$ the number of glaciers had the best match with 753 glaciers (756 glaciers $~ 100 \%$ ) and $95 \%$ of area. The best match for glacier area was achieved when shear stress threshold was reduced to $0.8 \times 10^{5} \mathrm{~Pa}$ with an area of $277.5 \mathrm{~km}^{2}\left(275.6 \mathrm{~km}^{2} \sim 100 \%\right)$ and $142 \%$ of number. I feel the overall best match is with the -B- parameters and a shear stress of $0.925 \times 105 \mathrm{~Pa}$ because the number of glaciers is very close, within 9 , to that of Post and others (1971) which represents $95 \%$ of the area, well within the uncertainty of Post. 


\section{Discussion \& Conclusions}

I attempted to match the $24 \mathrm{~K}$ inventory to the Post and others (1971) inventory using both an area threshold and shear stress criteria. An area threshold of $0.1 \mathrm{~km}^{2}$ resulted in 416 glaciers (55\%), an underestimate of the Post and others (1971) glacier population by 340 glaciers (45\%) (Table 3). Using a shear stress threshold of $1.0 \times 10^{5} \mathrm{~Pa}$ and the $-\mathrm{B}$ - parameters resulted in an underestimate of the Post and others (1971) inventory by 141 (19\%). Reducing the shear stress threshold to $0.925 \times 10^{5} \mathrm{~Pa}$ had a better match the Post and others (1971) inventory in the number of glaciers with 753 (100\%).

The differences between the $24 \mathrm{~K}$ and Post inventories may be influenced by cartographic misidentification of seasonal snow patches as perennial glacial features. I assumed Post and others (1971) are absolutely correct, however, features may also be misidentified. Unfortunately, we have no way to assess these errors in either inventory. 
Table 3 - Comparison of inventories using different methods. The 'features' column shows the division of the inventory based on the different methods of analysis. If the feature did not meet the threshold it is assumed to be a perennial snowfield. $B$ indicates features (glaciers) that meet the shear stress threshold defining movement using the B-set of scaling parameters.

\begin{tabular}{l|llrr}
\hline \hline Inventory & \multicolumn{1}{|c}{ Filter } & \multicolumn{1}{c}{ Feature } & Number & \multicolumn{1}{c}{ Total Area } \\
\hline 24K & None & All & 1935 & $288.36 \pm 12.49$ \\
& $<0.1 \mathrm{~km}^{2}$ & Perennial Snowfields & 1519 & $37.94 \pm 5.53$ \\
& $>0.1 \mathrm{~km}^{2}$ & Glaciers & 416 & $250.42 \pm 6.96$ \\
& $(-\mathrm{B}-)$ & Perennial Snowfields & 1334 & $28.64 \pm 4.45$ \\
& & Glaciers & 601 & $259.72 \pm 8.04$ \\
\hline \multirow{2}{*}{ 24K subset } & None & Glaciers & 697 & $259.07 \pm 10.35$ \\
& $<0.1 \mathrm{~km}^{2}$ & Perennial Snowfields & 283 & $15.32 \pm 1.67$ \\
& $>0.1 \mathrm{~km}^{2}$ & Glaciers & 414 & $243.75 \pm 6.95$ \\
\hline \multirow{2}{*}{ Post and } & None & Glaciers & 756 & $275.6 \pm 21.7$ \\
others (1971) & $=0.1 \mathrm{~km}^{2}$ & Perennial Snowfields & 411 & $41.1 \pm 4.0$ \\
& $>0.1 \mathrm{~km}^{2}$ & Glaciers & 345 & $255.3 \pm 15.5$
\end{tabular}

Within the North Cascades Park Complex, the comparison of 24K features that matched Post and others (1971) eliminated many of the $24 \mathrm{~K}$ features less than $0.1 \mathrm{~km}^{2}$ and the total area was only $1.7 \mathrm{~km}^{2}$ different (Granshaw \& Fountain, 2006). Basagic and Fountain (2011) in the Sierra Nevada, California also used both area and shear stress thresholds to estimate ‘true' glaciers from a California 24K glacier inventory compared to a Post and others (1971)-like inventory (Raub and others, 2006). The removal of glaciers smaller than $0.005 \mathrm{~km}^{2}$ resulted in a $102 \%$ area match in number of glaciers, which was better than using a $0.01 \mathrm{~km}^{2}$ threshold which resulted in a $69 \%$ area match. Using a shear stress threshold of $10^{5} \mathrm{~Pa}$, a match of only $14 \%$ in the number of glaciers, but reducing the threshold to $0.4 \times 10^{5} \mathrm{~Pa}$, the number of glaciers matched at $\sim 100 \%$ and the threshold to $0.5 \times 10^{5} \mathrm{~Pa}$ to match area to $\sim 100 \%$. The North Cascades has larger glaciers compared to Sierra Nevada and 
Raub and others (2006) had a smaller area threshold of $0.01 \mathrm{~km}^{2}$. The smaller features in the Sierra Nevada may account for more reduction in the shear stress threshold. When I reduced the shear stress to $0.8 \times 10^{5} \mathrm{~Pa}$, I had a $100 \%$ match in area. To get a better match in the number of glaciers, I reduced the shear stress value to $0.925 \times 10^{5} \mathrm{~Pa}$ and that resulted in a $100 \%$ match in the number of glaciers.

To answer the original questions of this chapter, the comparison between inventories showed the most difference in the features less than 0.1 $\mathrm{km}^{2}$. The inventories are nearly identical for features greater than $0.1 \mathrm{~km}^{2}, 83 \%$ number and $102 \%$ of area, with the main differences in number being the methodology used to catalog each feature. Based on my correction to the Post and others (1971) inventory using the $24 \mathrm{~K}$ area values for the features that Post and others (1971) identified as equal to $0.1 \mathrm{~km}^{2}$, the two inventories are comparable in number $(93 \%)$ and in total area $(94 \%)$. This finding supports that of Granshaw and Fountain (2006) and Basagic and Fountain (2011) and provides confidence in using the topographic variables derived from the $24 \mathrm{~K}$ to characterize the glaciers and perennial snowfields of the North Cascades. 


\section{Chapter 3 - Temporal Glacier Inventory}

Introduction

The glacier inventories presented in Chapter 2 are updated to define area change across the region. Additionally, a small subset of glaciers have been frequently monitored over the past century, including six on Mount Baker from 1900 to 2006 (Harper, 1993, Kovanen, 2003, Fountain and others, 2007a, Pelto, 1993, Pelto \& Brown, 2012, O'Neal, 2005), for which I updated for 2009. South Cascade Glacier has been monitored annually by the US Geological Survey since 1958 (Bidlake and others, 2007, 2012, Krimmel, 2001b, 2002b).

\section{Methods}

I compiled nine different inventories derived from a variety of data sources including aerial photography (1989-2009), topographic maps (Chapter 2), and Little Ice Age (LIA) extents based on glacial geology (Table 4). Orthorectified aerial photography was available in black and white for 1989, 1990, 1992, 1993, and 1998 and in color for 2006 and 2009. The 1989 imagery has a resolution of $2 \mathrm{~m}$ and the rest are $1 \mathrm{~m}$ resolution. 
Table 4 - Data sources and spatial coverage for glacier inventories and temporal data sets.

\begin{tabular}{|c|c|c|}
\hline$\overline{Y e a r}$ & Data Source & Spatial Extent \\
\hline LIA $(\sim 1900)$ & $\begin{array}{l}\text { North Cascades National Park } \\
\text { (Dr. Jon Riedel, personal } \\
\text { communication) }\end{array}$ & NOCA Park Complex \\
\hline $1953-1985$ & $\begin{array}{l}\text { USGS 1:24,000 Topographic Maps (Fountain } \\
\text { et al. 2007) }\end{array}$ & $\begin{array}{l}\text { North Cascades } \\
\text { Entire Region }\end{array}$ \\
\hline $1989-1998$ & $\begin{array}{l}\text { USGS Digital Ortho Quads Aerial Imagery } \\
\text { (DOQs)- Black and white - } \\
\text { (http://rocky2.ess.washington.edu/ } \\
\text { data/raster/doqs/index.html) }\end{array}$ & Variable \\
\hline 1998 & (Granshaw \& Fountain, 2006) & NOCA Park Complex \\
\hline 2006, 2009 & $\begin{array}{l}\text { National Agricultural Imagery Program } \\
\text { Aerial Imagery (NAIP) -Color- } \\
\text { (http://gis.ess.washington.edu/data } \\
\text { /raster/doqs_naip.html) }\end{array}$ & $\begin{array}{l}\text { North Cascades Entire } \\
\text { Region }\end{array}$ \\
\hline $1900-2006$ & $\begin{array}{l}\text { (Fountain and others, 2007a, } \\
\text { O'Neal, 2005) }\end{array}$ & Mount Baker \\
\hline $1958-2009$ & $\begin{array}{l}\text { (Meier \& Tangborn, 1965, Krimmel, 1989, } \\
\text { 1993, 1994, 1995, 1997, 1996, 1998, } \\
\text { 1999, 2000, 2001a, 2002a, Elsberg } \\
\text { and others, 2001, Bidlake and } \\
\text { others, 2004, 2005, 2007, 2010, } \\
\text { 2012) }\end{array}$ & South Cascade Glacier \\
\hline
\end{tabular}

The glacier outlines were manually digitized in ArcGIS at a 1:2000 scale with the streaming vertices editing tool placing vertices every $10 \mathrm{~m}$. This scale and vertex distance was chosen to balance accuracy with productivity. Once the outlines were digitized, the area within each outline was calculated using ArcGIS software. The area was calculated using an Albers-equal area projection to minimize any distortion relative to other projections. Glacier outlines were also obtained from the 24K topographic maps (Chapter 2). In addition, maximum glacier extent during the LIA was mapped within the North Cascades National Park Complex by Dr. Jon Riedel (personal communication). 
Radiocarbon, dendrochronology and lichenometry dating methods were applied to various moraine features on Mount Baker and the maximum extent was dated to the late $19^{\text {th }}$ century (Osborn and others, 2012). Photographs from the early $20^{\text {th }}$ century show that the glaciers are typically in contact with their LIA moraines (Basagic \& Fountain, 2011), the North Cascades are no exception ( Figure 9) therefore I assume that the LIA moraines in my study region outline the glacier extent in 1900 .
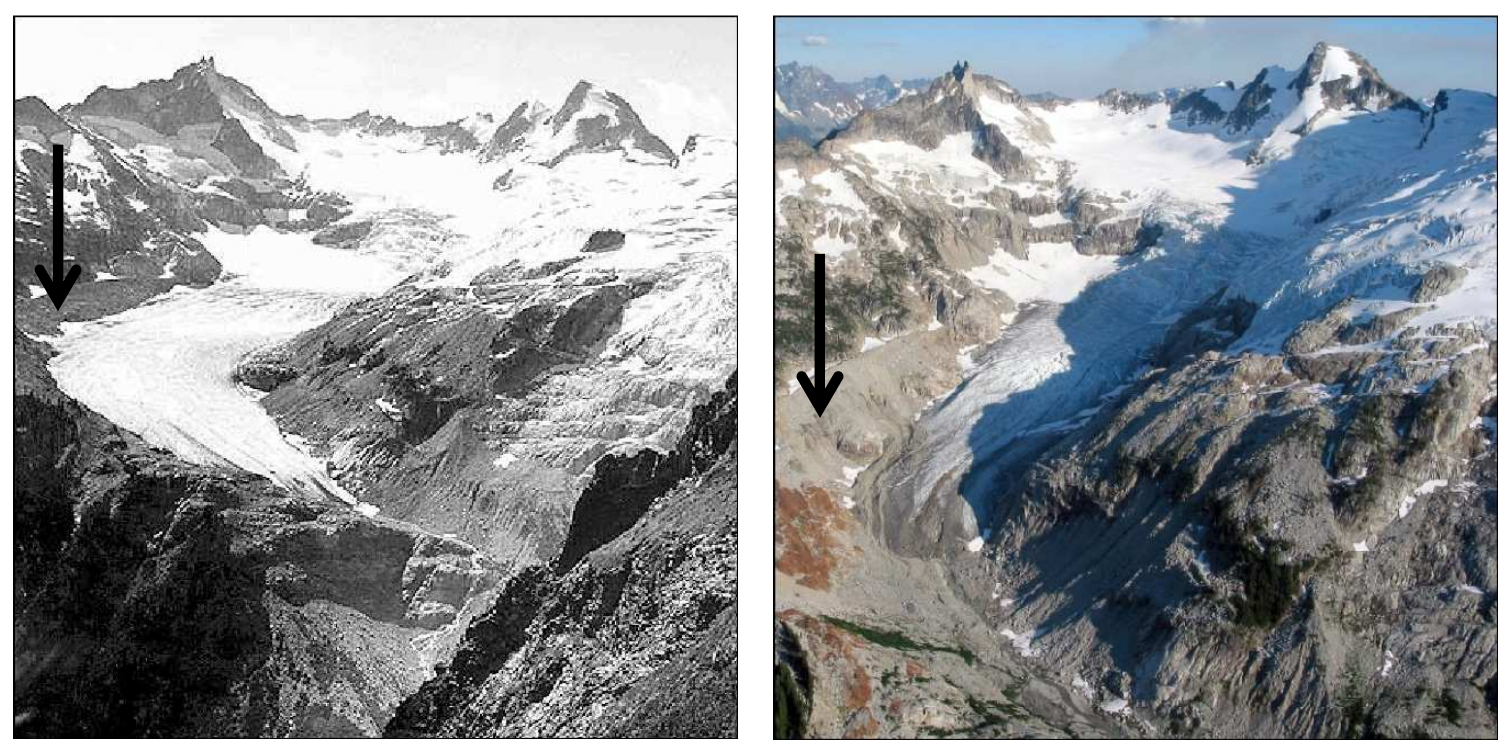

Figure 9 - Comparison of Chickamin Glacier from 1939 (left) and 2004 (right). The glacier is in contact with a lateral moraine in the 1939 photograph. Source: 1939 photographer-Dwight Watson from the University of Washington Special Collections; 2004 photograph taken by John Scurlock. Arrows are pointing to the same location on the LIA moraine in each photograph.

As a second check on the accuracy of glacier outlines, I compared area change for individual glaciers between inventories. For the largest area change I re-examined the outlines. If the change was due to a different interpretation 
or mis-interpretation of the largest outline, it was adjusted. After starting with the outliers, I progressively checked the glaciers with smaller and smaller changes until few or no corrections were needed. At this point I felt confident that further checking would result in little or no adjustments. In some cases seasonal snow cover or shadows obscured the glacier boundary and the glacier extent is classified as 'No Data' (Table 5). If a feature was originally misidentified as a glacier it was eliminated from the inventory.

The total uncertainty $\left(\mathrm{km}^{2}\right)$ is the root sum of squares of position, digitizing, and interpretation uncertainties, as expressed in equation (1) in Chapter 2. The positional uncertainty is defined as the accuracy of the aerial photography, which is the root mean square error calculated during the orthorectifying process. As mentioned previously, I assume positional uncertainty to be zero because any positional error will only shift the polygon and will not change the area (DeBeer \& Sharp, 2009). The digitizing uncertainty for the aerial photography was determined by digitizing glacier outlines at 1:2000 scale and again at 1:500. Interpretation uncertainty is estimated from the 2006 imagery from a sample of glaciers that were digitized independently by another person. The root mean square (RMS) difference between outlines is the interpretation uncertainty.

To calculate a normalized area change, I calculated a fractional area change (FAC) by subtracting the glacier area, $A$, (typically the most recent) from the initial glacier area, $A_{i}$, and dividing by the initial area. 


$$
F A C=\frac{A-A_{i}}{A_{i}}
$$

The uncertainty of area change $\left(U_{\Delta}\right)$ is the root sum of squares (RSS) of the uncertainty total from each year,

$$
U_{\Delta}=\frac{1}{2} \sqrt{U^{2}+U_{i}^{2}}
$$

where the uncertainty from the initial year is $\left(U_{i}\right)$, and the uncertainty from the most recent is $(U)$. The relative uncertainty $\left(U_{R}\right)$ is the RSS divided by original area, $A_{i}$.

$$
U_{R}=\frac{U_{\Delta}}{A_{i}}
$$

\section{Results}

The aerial imagery was of varying quality and spatial extent. The black and white imagery from 1989 - 1998 made it difficult to distinguish seasonal snow from firn and ice, and the extent of seasonal snow varied not only between years but also across the region. The color imagery from 2006 and 2009 (NAIP) made interpretation more clear (Figure 10). The number of glaciers identified in each inventory including the $24 \mathrm{~K}$ and LIA is listed in Table 5 , and details by glacier in Appendix A. 

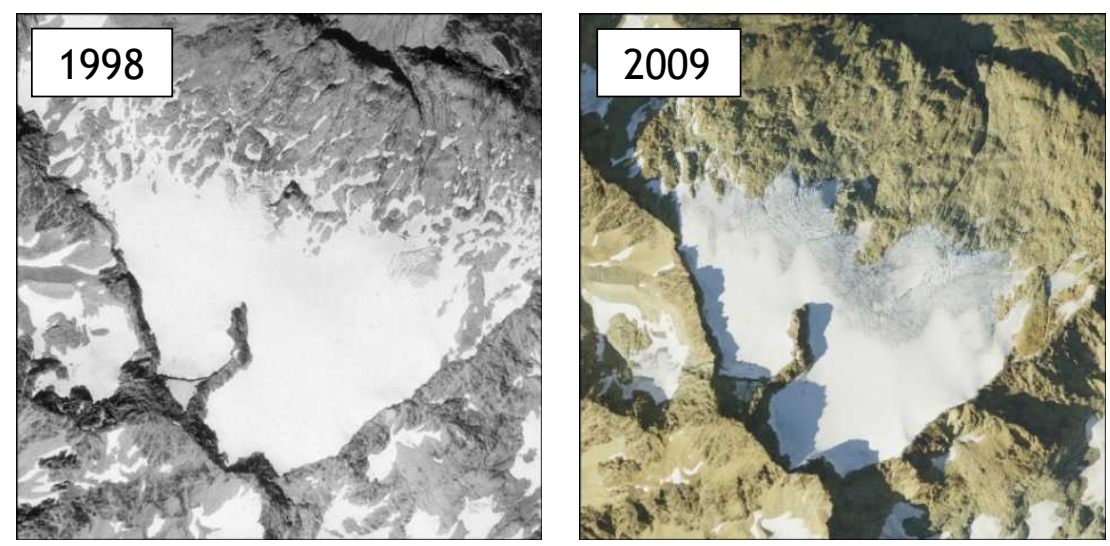

Figure 10 - The ability to define a glacier outline is enhanced when color photography (right) is available compared to black and white (left). Basin ID is 213202.

Table 5 - Results of the temporal glacier inventories. Potential is the number of glaciers within the spatial extent of the imagery. NoData are glaciers not included in the temporal analysis due to snow cover, shadows or misclassification. Final is the number of glaciers used in the analysis. Grouped Final is the year used in analysis and the final number of glaciers used in the analysis. The shaded area defines the mutually exclusive years in the $24 \mathrm{~K}$.

\begin{tabular}{lrrrrr}
\hline \hline Year & Potential & NoData & Final & \multicolumn{2}{c}{ Grouped Final } \\
\hline LIA & 314 & 7 & 307 & 1900 & 307 \\
1957 & 17 & 3 & 14 & 1958 & 288 \\
1958 & 301 & 31 & 271 & 1958 & \\
1959 & 6 & 3 & 3 & 1958 & \\
1963 & 15 & 5 & 10 & 1968 & 51 \\
1968 & 41 & 0 & 41 & 1968 & \\
1974 & 96 & 1 & 95 & 1974 & 124 \\
1975 & 30 & 1 & 29 & 1974 & \\
1979 & 1 & 0 & 1 & 1974 & \\
1983 & 85 & 5 & 80 & 1983 & 178 \\
1984 & 84 & 6 & 78 & 1983 & \\
1985 & 21 & 1 & 20 & 1983 & \\
1989 & 55 & 3 & 52 & 1990 & 293 \\
1990 & 198 & 16 & 180 & 1990 & \\
1992 & 75 & 63 & 12 & 1990 & \\
1993 & 51 & 1 & 49 & 1990 & \\
1998 & 654 & 116 & 534 & 1998 & 534 \\
2006 & 697 & 140 & 558 & 2009 & 683 \\
2009 & 697 & 323 & 375 & 2009 &
\end{tabular}


The positional uncertainty for the DOQs is 7m (USGS, 1996), for the NAIP imagery, both 2006 and 2009 it is 6m (USDA, 2008). Comparison of digitizing at 1:2000 versus a control effort at 1:500 for 40 glaciers reveals a digitizing uncertainty of $3 \mathrm{~m}$. The interpretation uncertainty examined 42 glaciers and the difference between outlines, compared to the average area, is normally distributed showing upwards of $50 \%$ variability (Figure 11). The greatest uncertainty is common to the smallest glaciers where it is often difficult to separate seasonal from perennial snow. The imagery used in this test had significant seasonal snow cover, and the independent digitizer was inexperienced with the region and did not have the advantage of knowing the historic glacier boundaries. The dataset was subdivided into two groups, one that has relatively little seasonal snow, and the other where snow was extensive. The interpretation uncertainty (root mean square of differences in area) of the snow-free group was $0.02 \mathrm{~km}^{2}$ and for the snowy group was 0.07 $\mathrm{km}^{2}$. I used the smaller $0.02 \mathrm{~km}^{2}$ uncertainty for the digitizing uncertainty of the outlines because I digitized all new inventories and examined cases of extensive variation between inventories as previously explained. 

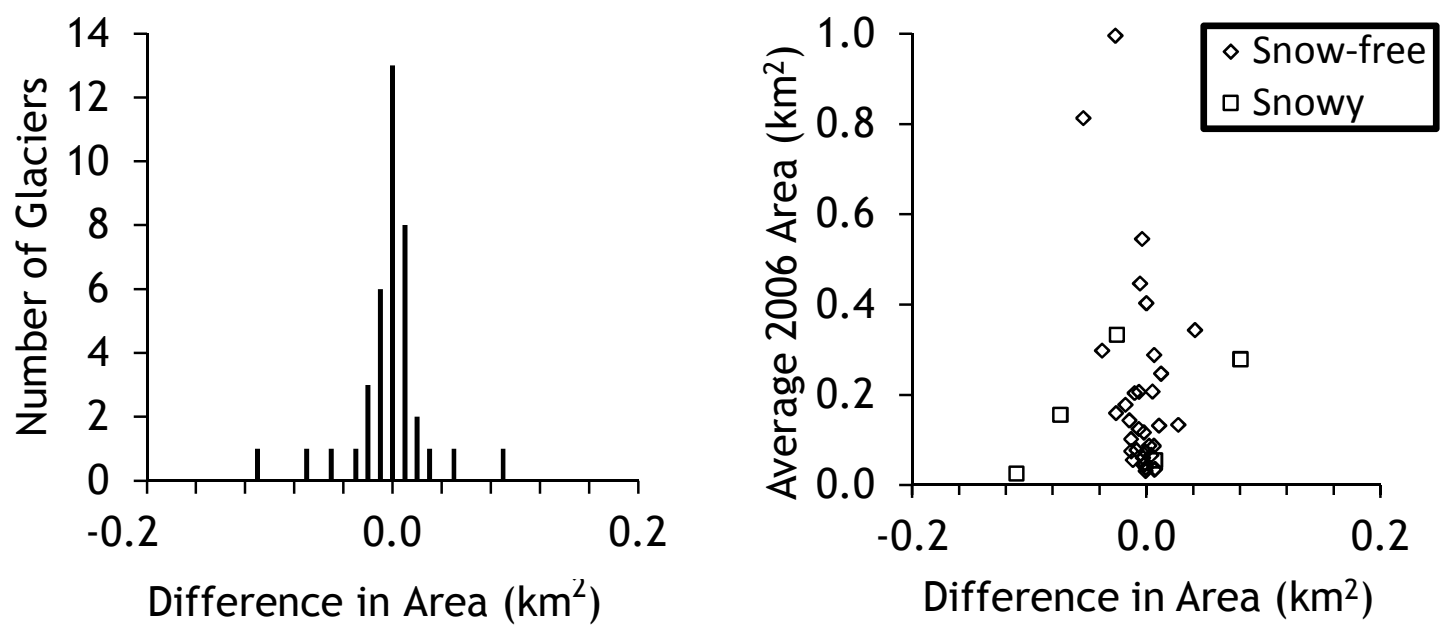

Figure 11 - Results of the two independent digitizing efforts. Histogram on left shows the distribution of area difference between two independent digitizing efforts. The graph on the right shows the difference with average area of the two independent digitizing efforts.

\section{Analysis}

Glacier change across the region

For analysis purposes, I grouped a number of different inventories together because those inventories were close together in time and mutually exclusive spatially. The $24 \mathrm{~K}$ glaciers which span 28 years were divided into four groups using the year that had the most features, 1958 includes 1957-1959, 1968 includes 1964-1968, 1974 include 1973-1975, and 1983 includes 1982-1985 (Table 5). For the 2006 and 2009 glacier outlines, they were combined as 2009. However, unlike the $24 \mathrm{~K}$ and DOQs, these two inventories are not mutually exclusive, but due to snow cover much of the landscape in 2009 was obscured and together these two inventories provide a complete coverage of the region. Also, only 3 years apart much of the change is observed in the uncertainty precluding estimating a meaningful difference over that 3 year period. The 
imagery in 2009 was better than 2006 where the glaciers were not completely snow covered. A 2009 glacier outline was only digitized if the imagery in 2009 was better than 2006. If there was no suitable 2009 outline, I used the 2006 glacier area value. If there were outlines for both 2006 and 2009 (247), I used the 2009 outline. For all but 44 of the 247 outlines change between 2006 and 2009 was less than uncertainty. The combined 2009 group has a total of 683 glaciers $\left(216.59 \mathrm{~km}^{2}\right)$ of which 313 glaciers $\left(46 \%\right.$ or $\left.68 \mathrm{~km}^{2}\right)$ were from 2006 and 370 glaciers $\left(54 \%\right.$ or $\left.148.59 \mathrm{~km}^{2}\right)$ were from 2009.

Due to variables of snow cover, shadows, and image quality not all glacier were outlined in all inventories. Table 6 shows the number of glaciers that each inventory has in common.

Table 6- The results of the temporal glacier inventory displaying the number of glaciers in common for each combination of inventories, (A) refers to the glacier time series that has a 1900 glacier outline in common with each other inventories $(B)$ is the inventories that have $24 \mathrm{~K}$ outlines in common and $(C)$ is the inventories that have an aerial imagery year in common. The inventories represent the combined inventories of Table 5.

\begin{tabular}{r|rrrr|rrrr|rrr}
\hline \hline & \multicolumn{5}{|c|}{$1900(\mathrm{~A})$} & \multicolumn{5}{|c|}{$24 \mathrm{~K}(\mathrm{~B})$} & \multicolumn{3}{|c}{ Aerial Imagery (C ) } \\
& 1900 & 1990 & 1998 & 2009 & 1958 & 1968 & 1974 & 1983 & 1990 & 1998 & 2009 \\
\hline 1900 & 307 & 153 & 283 & 303 & 128 & 15 & 67 & 76 & 153 & 283 & 303 \\
1958 & 128 & 54 & 121 & 126 & 288 & & & & 100 & 243 & 278 \\
1968 & 15 & 11 & 13 & 15 & & 51 & & & 32 & 25 & 42 \\
1974 & 67 & 30 & 59 & 67 & & & 124 & & 44 & 85 & 122 \\
1983 & 76 & 47 & 72 & 76 & & & & 178 & 87 & 124 & 173 \\
1990 & 153 & 153 & 140 & 151 & 100 & 32 & 44 & 87 & 293 & 189 & 280 \\
1998 & 283 & 140 & 283 & 280 & 243 & 25 & 85 & 124 & 189 & 534 & 517 \\
2009 & 303 & 151 & 280 & 303 & 278 & 42 & 122 & 173 & 280 & 517 & 683
\end{tabular}


Table 7 - Sample size of identical glaciers present in each inventory. Group 1 has the 1900 inventory in common, and group 2 has the $24 \mathrm{~K}$ and the 1990 in common. Insufficient numbers of glaciers are present in the 1990 and 1990 inventories precluding comparison.

\begin{tabular}{|c|c|c|c|}
\hline & \multicolumn{2}{|c|}{ Temporal Sequence } & Number of Glaciers \\
\hline \multirow{4}{*}{$\begin{array}{l}\bar{o} \\
\text { o } \\
\text { 는 }\end{array}$} & 1900-1958- & $-1998-2009$ & 116 \\
\hline & 1900-1968- & $-1998-2009$ & 7 \\
\hline & 1900-1974- & $-1998-2009$ & 41 \\
\hline & 1900-1983- & $-1998-2009$ & 56 \\
\hline \multirow{4}{*}{$\begin{array}{l}N \\
\text { O } \\
\text { O } \\
\text { ㄴ }\end{array}$} & \multicolumn{2}{|c|}{ 1958-1990-1998-2009 } & 65 \\
\hline & \multicolumn{2}{|c|}{$1968-1990-1998-2009$} & 14 \\
\hline & \multicolumn{2}{|c|}{$1974-1990-1998-2009$} & 16 \\
\hline & \multicolumn{2}{|c|}{ 1983-1998-1990-2009 } & 42 \\
\hline
\end{tabular}

To track glacier change in the region I used two methods. First, I compared the same glaciers across the various inventories and, second, compared the partially sampled populations of glaciers that may be composed of partially overlapping sets of glaciers (Table 6). The advantage of tracking identical glaciers across inventories is certainty of knowing the change applies to the same group of glaciers and is a precise measure. The disadvantage is that the set of glaciers is small and how representative that set is of the entire population may be questionable. The second method has the advantage of large datasets, which better approximate changes in the population, however, because the sets do not use all the same glaciers some change may be due to differences in glaciers sampled.

To track the identical glaciers over time, several subsets were identified (Table 7). These subsets are divided into two groups. Group 1 is limited to the 
North Cascades Park Complex where the LIA outlines (1900) were confined.

Group 2 is more geographically dispersed across the region (Table 8).

Table 8 - Total area and uncertainty $\left(\mathrm{km}^{2}\right)$ for the two different groups of glaciers within each group the same glaciers are tracked across the inventories. The first column is the inventory year, $24 \mathrm{~K}$ in column 1 representing different years, as indicated by the $24 \mathrm{~K}$ column heading. For example for the $3^{\text {rd }}$ column, 1968 , the year for the $24 \mathrm{~K}$ in column 1 is 1968 so the sequence of area in the $3^{\text {rd }}$ column is $1900,1968,1998$, and 2009 , for the same 7 (n) glaciers.

\begin{tabular}{|c|c|c|c|c|c|}
\hline \multicolumn{2}{|c|}{$24 K$} & 1958 & 1968 & 1974 & 1983 \\
\hline \multirow{5}{*}{$\begin{array}{l}\bar{o} \\
\text { 은 } \\
\text { ㄴ. }\end{array}$} & $\mathrm{n}$ & 116 & 7 & 41 & 65 \\
\hline & 1900 & $95.58 \pm 2.35$ & $5.74 \pm 0.21$ & $46.20 \pm 1.14$ & $51.18 \pm 1.42$ \\
\hline & $24 \mathrm{~K}$ & $50.41 \pm 1.99$ & $3.01 \pm 0.21$ & $23.38 \pm 0.78$ & $27.70 \pm 1.13$ \\
\hline & 1998 & $47.90 \pm 1.47$ & $2.61 \pm 0.15$ & $21.85 \pm 0.71$ & $25.29 \pm 0.92$ \\
\hline & 2009 & $43.66 \pm 1.44$ & $2.30 \pm 0.15$ & $17.69 \pm 0.69$ & $20.99 \pm 0.90$ \\
\hline \multirow{5}{*}{$\begin{array}{l}N \\
\text { 음 } \\
\frac{0}{\cup}\end{array}$} & $\mathrm{n}$ & 65 & 14 & 16 & 43 \\
\hline & $24 K$ & $35.25 \pm 1.32$ & $5.21 \pm 0.21$ & $4.13 \pm 0.25$ & $23.45 \pm 0.96$ \\
\hline & 1990 & $35.13 \pm 0.75$ & $4.83 \pm 0.21$ & $3.99 \pm 0.28$ & $22.65 \pm 0.72$ \\
\hline & 1998 & $33.68 \pm 0.74$ & $4.49 \pm 0.21$ & $3.48 \pm 0.28$ & $21.61 \pm 0.72$ \\
\hline & 2009 & $31.04 \pm 0.73$ & $4.05 \pm 0.21$ & $2.42 \pm 0.27$ & $18.47 \pm 0.70$ \\
\hline
\end{tabular}

For group 1, the relative change between 1900 and the four $24 \mathrm{~K}$ years are similar, with a reduction of glacier are by about half of the original area (Table 9). The change between the $24 \mathrm{~K}$ years and 1998 varies between $-5 \%$ to $-13 \%$; between 1998 and 2009 ranges from $-9 \%$ to $-19 \%$. The change for all periods is similar within each period given the uncertainty (Figure 12). 
Table 9 - Fractional area change of total area of the same glaciers over the period 1900-2009 from group 1 and from 24K to 2009 from group 2 (Table 8). The columns represent different datasets of glaciers that correspond to the individual years in the $24 \mathrm{~K}$ inventory. The change is relative to the first year in the specific time periods over time starting with 1900 (group 1) and the 24K years the four 24K years are 1958, 1968, 1974, and 1983 (group 2).

\begin{tabular}{|c|c|c|c|c|c|c|}
\hline \multicolumn{3}{|c|}{$P$} & $24 \mathrm{~K}=1958$ & $24 \mathrm{~K}=1968$ & $24 \mathrm{~K}=1974$ & $24 \mathrm{~K}=1983$ \\
\hline \multirow{6}{*}{$\begin{array}{l}\overline{0} \\
\text { o } \\
\text { 는 }\end{array}$} & & & $(n=116)$ & $(n=7)$ & $(n=41)$ & $(n=65)$ \\
\hline & 1900 & $24 \mathrm{~K}$ & $-47 \% \pm 3 \%$ & $-48 \% \pm 5 \%$ & $-49 \% \pm 3 \%$ & $-46 \% \pm 4 \%$ \\
\hline & $24 \mathrm{~K}$ & 1998 & $-5 \% \pm$ & $-13 \% \pm 8 \%$ & $-7 \% \pm 5 \%$ & $-9 \% \pm 5 \%$ \\
\hline & 1998 & 2009 & $-9 \% \pm 4 \%$ & $-12 \% \pm 8 \%$ & $-19 \% \pm 5 \%$ & $-17 \% \pm 5 \%$ \\
\hline & $2 \overline{4 k}$ & 2009 & $-13 \% \pm 5 \%$ & $-24 \% \pm 8 \%$ & $-2 \overline{4} \% \pm 4 \%$ & $-24 \% \pm 5 \%$ \\
\hline & 1900 & 2009 & $-54 \% \pm 3 \%$ & $-60 \% \pm 4 \%$ & $-62 \% \pm 3 \%$ & $-59 \% \pm 3 \%$ \\
\hline & & & $(n=65)$ & $(n=14)$ & $(n=16)$ & $(n=42)$ \\
\hline & $24 K$ & 1990 & $0 \% \pm 4 \%$ & $-7 \% \pm 6 \%$ & $-3 \% \pm 9 \%$ & $-3 \% \pm 5 \%$ \\
\hline & 1990 & 1998 & $-4 \% \pm 3 \%$ & $-7 \% \pm 6 \%$ & $-13 \% \pm 10 \%$ & $-5 \% \pm 5 \%$ \\
\hline & 1998 & 2009 & $-8 \% \pm 3 \%$ & $-10 \% \pm 7 \%$ & $-30 \% \pm 11 \%$ & $-15 \% \pm 5 \%$ \\
\hline & $2 \overline{4 k}$ & 2009 & $-13 \% \pm 5 \%$ & $-16 \% \pm 6 \%$ & $-39 \% \pm 10 \%$ & $-18 \% \pm 4 \%$ \\
\hline
\end{tabular}

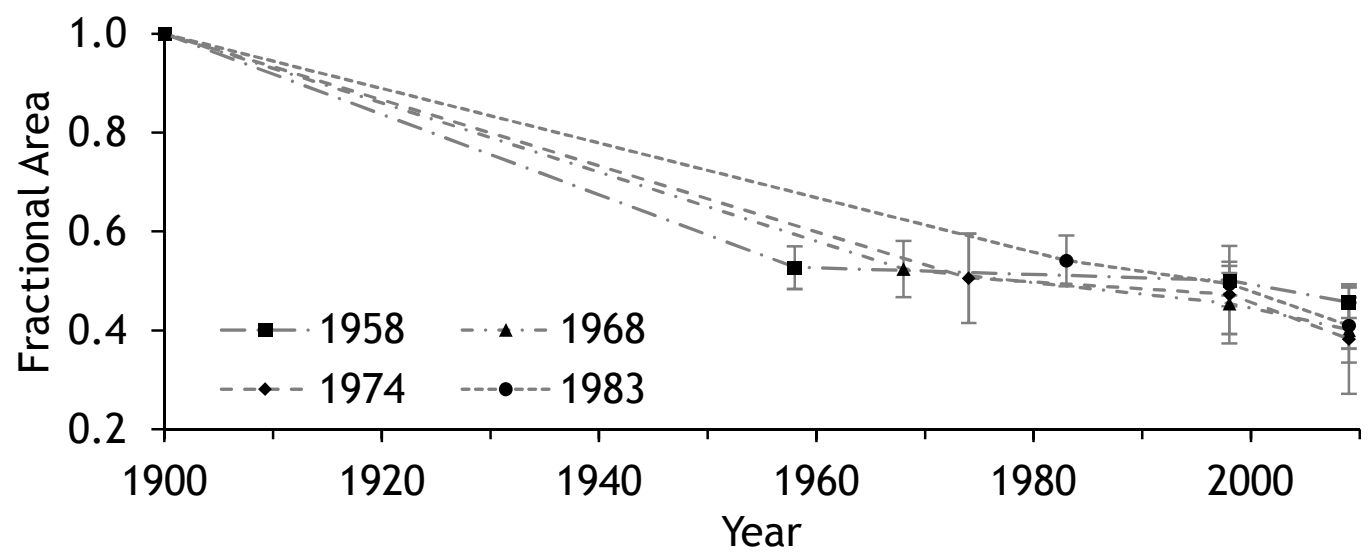

Figure 12 - Area change of the same glaciers for each temporal sequence grouped by $24 \mathrm{~K}$ year from 1900-2009.

For group 2 no significant area change occurs between four 24K years and 1990 (Table 9); between 1990 and 1998 a small decrease occurs of about 1\% given uncertainty; for 1998 and 2009 significant shrinkage occurs but variable. The 
first two sets $(n=65, n=14)$ are similar and the latter two show much more change (Figure 13).

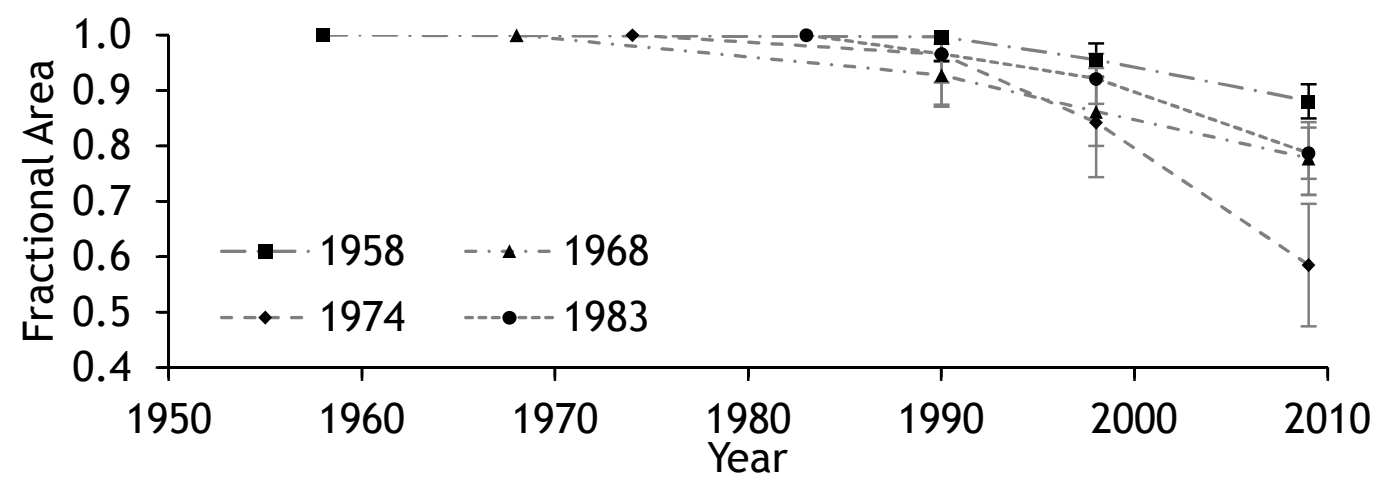

Figure 13 - Area change of identical glaciers for each temporal sequence grouped by $24 \mathrm{~K}$ year to 2009 .

For the larger and partially overlapping datasets, nine different time periods were used (Table 10) to best quantify the glacier change in the region. To test whether the sets are from the same or different populations the topographic characteristics are examined, derived from the $24 \mathrm{~K}$ data. 
Table 10 - A comparison of the topographic characteristics of each set of glaciers. The topographic data are derived from the $24 \mathrm{~K}$ data, $n$ is the number of glaciers, $Z$ is the mean glacier elevation, $\sigma Z$ is standard deviation of elevation, $A$ is the mean glacier area, and $\sigma A$ is the standard deviation of the area. Aspect is the fraction facing each direction. The italics indicate a statistical difference from the other data sets.

\begin{tabular}{l|rcccccccc}
\hline \hline & & $\mathrm{Z}$ & $\sigma Z$ & $\mathrm{~A}$ & \multicolumn{3}{c}{$\sigma \mathrm{A}$} & \multicolumn{4}{c}{ Aspect $(\%)$} \\
& $\mathrm{n}$ & $(\mathrm{m})$ & $(\mathrm{m})$ & $\left(\mathrm{km}^{2}\right)$ & $\left(\mathrm{km}^{2}\right)$ & $\mathrm{N}$ & \multicolumn{1}{c}{$\mathrm{E}$} & \multicolumn{1}{c}{$\mathrm{S}$} & $\mathrm{W}$ \\
\hline All 24K & 642 & 2013 & $\mathbf{2 3 6}$ & $\mathbf{0 . 3 7 3}$ & $\mathbf{0 . 7 4 0}$ & $\mathbf{5 2}$ & $\mathbf{2 8}$ & $\mathbf{9}$ & $\mathbf{1 1}$ \\
$1900-1958$ & 100 & 2063 & 193 & 0.444 & 0.959 & 56 & 20 & 12 & 13 \\
$1958-1990$ & 189 & 2053 & 233 & 0.422 & 0.929 & 59 & 22 & 6 & 13 \\
$1990-1998$ & 517 & 2007 & 214 & 0.387 & 0.754 & 57 & 26 & 6 & 10 \\
$1998-2009$ & 278 & 1996 & 223 & 0.365 & 0.665 & 52 & 27 & 9 & 12 \\
$1900-2009$ & 128 & 1985 & 219 & 0.449 & 0.883 & 50 & 27 & 10 & 13 \\
$-1958-2009$ & 303 & 2038 & 213 & 0.330 & 0.745 & 51 & 25 & 11 & 13 \\
$1968-2009$ & 42 & 2082 & 220 & 0.209 & 0.332 & 69 & 24 & 5 & 2 \\
$1974-2009$ & 122 & 1861 & 199 & 0.589 & 1.065 & 53 & 28 & 8 & 11 \\
$1983-2009$ & 173 & 2031 & 246 & 0.428 & 0.601 & 47 & 34 & 7 & 12
\end{tabular}

The results of a one-way ANOVA test show that the means of elevation and area are not statistically different at the $95 \%$ level between sets, except for 1974-2009. Aspect is not different between sets. Therefore, with the exception of 1974-2009 all sets are considered equivalent populations and their changes can be compared. The 1974-2009 dataset is excluded from further comparison. Total and fractional area change for the nine time periods were then subdivided into five groups, one for the entire set, two based on glacier size ( $<>$ $0.1 \mathrm{~km}^{2}$ ) and two based on statistical significance of area change (significant/insignificant). The motivation for the grouping rests on the observation that small glaciers are much more variable due relatively high interpretation uncertainty. 
Table 11a - Area change over different time periods separated by areas greater/less than $0.1 \mathrm{~km}^{2}$ based on their initial area and by significant and insignificant changes, $\mathrm{n}$ is the number of glaciers, $\mathrm{FAC}$ is fractional area change.

\begin{tabular}{|c|c|c|c|c|c|}
\hline & $\mathrm{n}$ & \multicolumn{2}{|c|}{$\begin{array}{l}\text { Area } \\
\left(\mathrm{km}^{2}\right)\end{array}$} & \multirow[t]{2}{*}{$\begin{array}{c}\text { Total Area } \\
\text { Change }\end{array}$} & \multirow[t]{2}{*}{ FAC } \\
\hline $1900-2009$ & & 1900 & 2009 & & \\
\hline All & 303 & $246.22 \pm 5.97$ & $113.34 \pm 3.67$ & $-132.87 \pm 7.01$ & $-54 \% \pm 3 \%$ \\
\hline$A>0.1 \mathrm{~km}^{2}$ & 277 & $244.44 \pm 5.79$ & $112.56 \pm 3.41$ & $-131.89 \pm 6.72$ & $-54 \% \pm 3 \%$ \\
\hline$A<0.1 \mathrm{~km}^{2}$ & 26 & $1.77 \pm 0.17$ & $0.79 \pm 0.27$ & $-0.98 \pm 0.32$ & $-56 \% \pm 18 \%$ \\
\hline Sig. $\Delta$ & 295 & $245.70 \pm 5.92$ & $112.97 \pm 3.59$ & $-132.73 \pm 6.92$ & $-54 \% \pm 3 \%$ \\
\hline Insig. $\Delta$ & 8 & $0.51 \pm 0.05$ & $0.37 \pm 0.08$ & $-0.14 \pm 0.10$ & $-27 \% \pm 19 \%$ \\
\hline $1900-1958$ & & 1900 & 1958 & & \\
\hline All & 128 & $105.99 \pm 2.54$ & $56.85 \pm 2.13$ & $-49.15 \pm 3.31$ & $-46 \% \pm 3 \%$ \\
\hline$A>0.1 \mathrm{~km}^{2}$ & 118 & $105.31 \pm 2.47$ & $56.39 \pm 2.03$ & $-48.92 \pm 3.20$ & $-46 \% \pm 3 \%$ \\
\hline$A<0.1 \mathrm{~km}^{2}$ & 10 & $0.68 \pm 0.07$ & $0.46 \pm 0.10$ & $-0.22 \pm 0.12$ & $-33 \% \pm 18 \%$ \\
\hline Sig. $\Delta$ & 123 & $105.17 \pm 2.49$ & $56.39 \pm 1.80$ & $-48.78 \pm 3.07$ & $-46 \% \pm 3 \%$ \\
\hline Insig. $\Delta$ & 5 & $0.82 \pm 0.05$ & $0.45 \pm 0.33$ & $-0.37 \pm 0.33$ & $-45 \% \pm 40 \%$ \\
\hline $1958-1990$ & & 1958 & 1990 & & \\
\hline All & 100 & $42.18 \pm 1.72$ & $41.32 \pm 1.23$ & $-0.87 \pm 2.11$ & $-2 \% \pm 5 \%$ \\
\hline$A>0.1 \mathrm{~km}^{2}$ & 55 & $39.53 \pm 1.32$ & $38.92 \pm 0.76$ & $-0.61 \pm 1.53$ & $-2 \% \pm 4 \%$ \\
\hline$A<0.1 \mathrm{~km}^{2}$ & 45 & $2.65 \pm 0.39$ & $2.40 \pm 0.47$ & $-0.25 \pm 0.61$ & $-10 \% \pm 23 \%$ \\
\hline Sig. $\Delta$ & 18 & $11.75 \pm 0.31$ & $11.15 \pm 0.24$ & $-0.60 \pm 0.39$ & $-5 \% \pm 3 \%$ \\
\hline Insig. $\Delta$ & 82 & $30.43 \pm 1.40$ & $30.17 \pm 0.99$ & $-0.26 \pm 1.72$ & $-1 \% \pm 6 \%$ \\
\hline $1990-1998$ & & 1990 & 1998 & & \\
\hline All & 189 & $72.56 \pm 2.33$ & $68.89 \pm 2.30$ & $-3.67 \pm 3.27$ & $-5 \% \pm 5 \%$ \\
\hline$A>0.1 \mathrm{~km}^{2}$ & 122 & $68.67 \pm 1.63$ & $65.29 \pm 1.61$ & $-3.38 \pm 2.28$ & $-5 \% \pm 3 \%$ \\
\hline$A<0.1 \mathrm{~km}^{2}$ & 67 & $3.89 \pm 0.70$ & $3.60 \pm 0.70$ & $-0.29 \pm 0.99$ & $-8 \% \pm 25 \%$ \\
\hline Sig. $\Delta$ & 43 & $37.29 \pm 0.63$ & $34.48 \pm 0.62$ & $-2.81 \pm 0.88$ & $-8 \% \pm 2 \%$ \\
\hline Insig. $\Delta$ & 146 & $35.27 \pm 1.69$ & $34.41 \pm 1.69$ & $-0.86 \pm 2.39$ & $-2 \% \pm 7 \%$ \\
\hline $1998-2009$ & & 1998 & 2009 & & \\
\hline All & 517 & $171.16 \pm 6.22$ & $150.82 \pm 6.11$ & $-20.34 \pm 8.72$ & $-12 \% \pm 5 \%$ \\
\hline$A>0.1 \mathrm{~km}^{2}$ & 288 & $158.51 \pm 3.83$ & $140.43 \pm 3.73$ & $-18.08 \pm 5.35$ & $-11 \% \pm 3 \%$ \\
\hline$A<0.1 \mathrm{~km}^{2}$ & 229 & $12.65 \pm 2.39$ & $10.38 \pm 2.37$ & $-2.26 \pm 3.37$ & $-18 \% \pm 27 \%$ \\
\hline Sig. $\Delta$ & 171 & $118.43 \pm 2.39$ & $101.29 \pm 2.30$ & $-17.14 \pm 3.32$ & $-14 \% \pm 3 \%$ \\
\hline Insig. $\Delta$ & 346 & $52.73 \pm 3.83$ & $49.52 \pm 3.81$ & $-3.21 \pm 5.40$ & $-6 \% \pm 10 \%$ \\
\hline
\end{tabular}


Table 11b - Area change over different time periods separated by areas greater/less than $0.1 \mathrm{~km}^{2}$ based on their initial area and by significant and insignificant changes, $\mathrm{n}$ is the number of glaciers, $\mathrm{FAC}$ is fractional area change.

\begin{tabular}{lr|rccc}
\hline \hline & & \multicolumn{2}{|c}{$\begin{array}{c}\text { Area } \\
\left(\mathrm{km}^{2}\right)\end{array}$} & $\begin{array}{c}\text { Total Area } \\
\text { Change }\end{array}$ & FAC \\
\hline $1958-2009$ & & \multicolumn{1}{|c}{1958} & 2009 & & \\
All & 278 & $91.67 \pm 3.92$ & $78.07 \pm 3.25$ & $-13.60 \pm 5.09$ & $-15 \% \pm 6 \%$ \\
A $>0.1 \mathrm{~km}^{2}$ & 152 & $84.76 \pm 2.88$ & $72.53 \pm 1.94$ & $-12.23 \pm 3.47$ & $-14 \% \pm 4 \%$ \\
A $<0.1 \mathrm{~km}^{2}$ & 126 & $6.91 \pm 1.04$ & $5.54 \pm 1.30$ & $-1.37 \pm 1.67$ & $-20 \% \pm 24 \%$ \\
Sig. $\Delta$ & 88 & $66.15 \pm 1.62$ & $54.73 \pm 1.18$ & $-11.42 \pm 2.01$ & $-17 \% \pm 3 \%$ \\
Insig. $\Delta$ & 190 & $25.52 \pm 2.30$ & $23.34 \pm 2.07$ & $-2.18 \pm 3.09$ & $-9 \% \pm 12 \%$ \\
1968-2009 & & 1968 & 2009 & & \\
All & 42 & $8.77 \pm 0.47$ & $6.91 \pm 0.47$ & $-1.86 \pm 0.66$ & $-21 \% \pm 8 \%$ \\
A $>0.1 \mathrm{~km}^{2}$ & 20 & $7.75 \pm 0.29$ & $6.11 \pm 0.24$ & $-1.64 \pm 0.38$ & $-21 \% \pm 5 \%$ \\
A $<0.1 \mathrm{~km}^{2}$ & 22 & $1.02 \pm 0.18$ & $0.80 \pm 0.23$ & $-0.22 \pm 0.29$ & $-22 \% \pm 28 \%$ \\
Sig. $\Delta$ & 15 & $6.96 \pm 0.24$ & $5.38 \pm 0.19$ & $-1.58 \pm 0.30$ & $-23 \% \pm 4 \%$ \\
Insig. $\Delta$ & 27 & $1.81 \pm 0.23$ & $1.53 \pm 0.28$ & $-0.28 \pm 0.36$ & $-16 \% \pm 20 \%$ \\
1983-2009 & & 1983 & 2009 & & \\
All & 173 & $71.24 \pm 2.58$ & $55.78 \pm 2.09$ & $-15.46 \pm 3.32$ & $-22 \% \pm 5 \%$ \\
A $>0.1 \mathrm{~km}^{2}$ & 132 & $68.78 \pm 2.29$ & $54.08 \pm 1.66$ & $-14.70 \pm 2.83$ & $-21 \% \pm 4 \%$ \\
A $<0.1 \mathrm{~km}^{2}$ & 41 & $2.46 \pm 0.29$ & $1.70 \pm 0.42$ & $-0.76 \pm 0.51$ & $-31 \% \pm 21 \%$ \\
Sig. $\Delta$ & 125 & $63.18 \pm 2.01$ & $48.23 \pm 1.55$ & $-14.95 \pm 2.54$ & $-24 \% \pm 4 \%$ \\
Insig. $\Delta$ & 48 & $8.06 \pm 0.57$ & $7.55 \pm 0.53$ & $-0.51 \pm 0.78$ & $-6 \% \pm 10 \%$
\end{tabular}

Table $11(a, b)$ shows the overall change from 1900-2009 $(-54 \% \pm 3 \%)$ has the most variability in the smaller glaciers, but most glaciers (97\%) significantly changed. Most of the change in glacier area occurred from 1900-1958 (-46\% \pm $3 \%$ ) with $96 \%$ shrinking significantly, whereas from $1958-2009$ (-15\% $\pm 6 \%) 32 \%$ glaciers changing significantly. As suspected the uncertainty for the smaller glaciers is relatively greater than that for the larger glaciers and over shorter time periods the small change observed is often smaller than the uncertainty, these results can be seen graphically. 

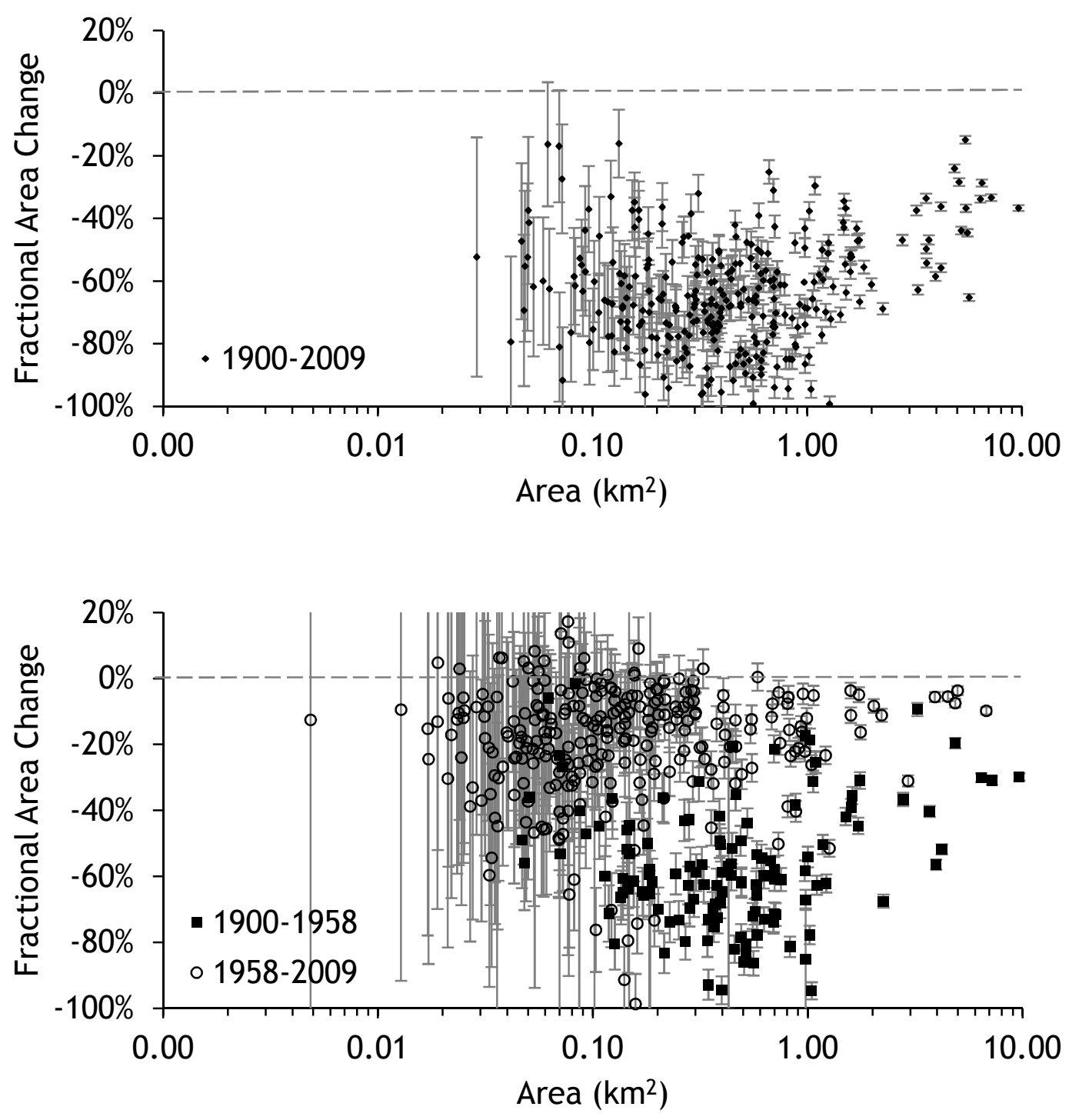

Figure 14 - Fractional area change for different temporal area change groups. The upper graph shows the overall fractional area change from 1900-2009. The lower graph breaks up the change into two nearly equal periods, 1900-1958 and 1958-2009.

For each period the glaciers with insignificant change were examined to detect any similarities among them or differences from the glaciers with significant 
change. There are two main characteristics associated with glaciers showing insignificant change, time between inventories and glacier size (Table 12).

Table 12 - Analysis of glaciers with insignificant change. The variables used in the comparison are number of years, percent of glaciers that have insignificant change out of the total number analyzed, average and standard deviation $(\sigma)$ of fractional area change, average relative uncertainty FAC, original area of the glaciers, average and standard deviation $(\sigma)$ of initial area.

\begin{tabular}{l|crrrrrr}
\hline \hline & $\begin{array}{c}\text { Number } \\
\text { of } \\
\text { Years }\end{array}$ & $\begin{array}{c}\text { Percent } \\
\text { of } \\
\text { Group }\end{array}$ & $\begin{array}{c}\text { Average } \\
\text { FAC }\end{array}$ & $\begin{array}{c}\text { Average } \\
\sigma_{\text {FAC }}\end{array}$ & $\begin{array}{c}\text { Average } \\
\text { Uncertainty }\end{array}$ & $\begin{array}{c}\text { Original } \\
\text { Area }\end{array}$ & $\sigma_{\text {Area }}$ \\
\hline $1900-2009$ & 109 & $3 \%$ & $-32 \%$ & $14 \%$ & 0.012 & 0.064 & 0.029 \\
$1900-1958$ & 58 & $4 \%$ & $-29 \%$ & $24 \%$ & 0.067 & 0.165 & 0.138 \\
$1958-1990$ & 32 & $86 \%$ & $-4 \%$ & $11 \%$ & 0.022 & 0.371 & 0.895 \\
$1990-1998$ & 8 & $78 \%$ & $-5 \%$ & $13 \%$ & 0.016 & 0.242 & 0.402 \\
$1998-2009$ & 11 & $68 \%$ & $-11 \%$ & $16 \%$ & 0.016 & 0.152 & 0.257 \\
\hline $1958-2009$ & 51 & $68 \%$ & $-13 \%$ & $12 \%$ & 0.017 & 0.134 & 0.184 \\
$1968-2009$ & 41 & $64 \%$ & $-22 \%$ & $18 \%$ & 0.014 & 0.067 & 0.050 \\
$1983-2009$ & 26 & $27 \%$ & $-13 \%$ & $16 \%$ & 0.017 & 0.168 & 0.245
\end{tabular}

The time interval between glacier inventories influences the fraction of glaciers with insignificant change. For example, over the entire time period from $1900-2009$ only $3 \%$ of the glaciers did not experience significant change, whereas for the eight year period between 1990 and 1998, 78\% did not exhibit significant change. Certainly slowly changing glaciers will not show significant change over short time periods so climate plays a role here as well. Larger glaciers, with an overall larger total uncertainty exhibit a smaller fractional uncertainty whereas small glaciers, particularly those less than $0.1 \mathrm{~km}^{2}$ have much larger relative uncertainty (Figure 15b). 
a.

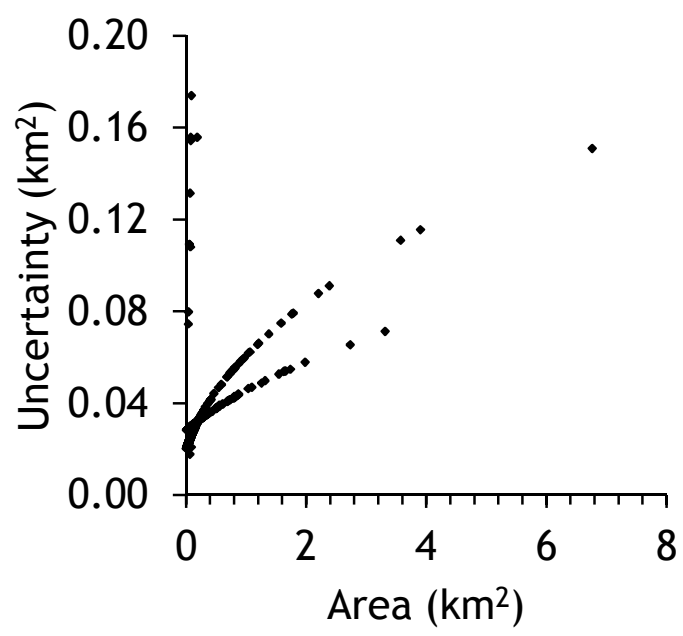

b.

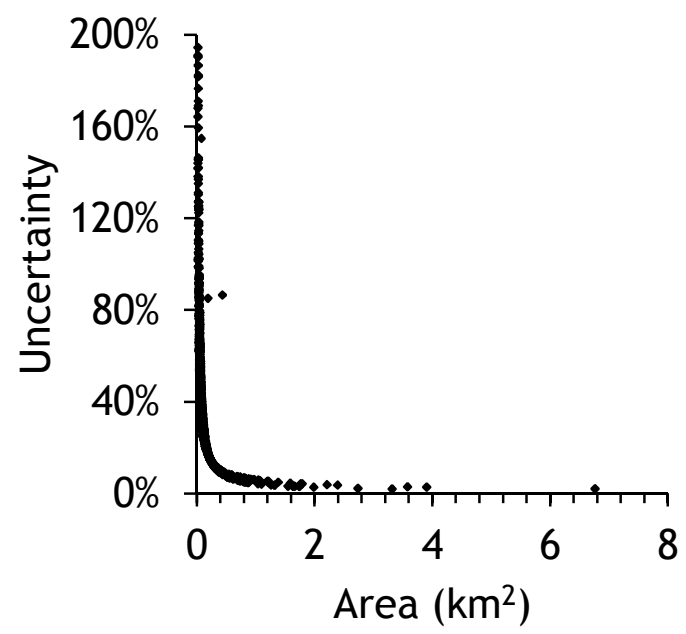

Figure 15 - Uncertainty of all area change years compared to original area of the glacier. (a) Uncertainty of area change as a fraction of initial area, (b) uncertainty of area change as a percent of initial area. The two arms in (a) represent the uncertainty associated with the $24 \mathrm{~K}$ and aerial photography since the digitizing uncertainty is different for inventories with those data sources.

\section{Estimating Glacier Change for the Region}

To estimate total glacier area over time for the entire North Cascades, I used the total fractional change for each time intervals from Table 11. To estimate the total glacier total area at any time (6) can be rewritten as,

$$
A=A_{i}(F A C+1)
$$

where, $A$ is the area at the time of interest and $A_{i}$ is the initial total area. Using the $24 \mathrm{~K}$ as the initial area the remaining areas can be bootstrapped. For example, the total area for 1990 is estimated from the change since $24 \mathrm{~K}$ year 1958, then the area in 1998 can be estimated from the change since 1990, and so on. This approach was applied to the time intervals in the following sequence, $1900 \leftarrow 1958,1958 \rightarrow 1990,1990 \rightarrow 1998,1998 \rightarrow 2009$ then $1968 \leftarrow 2009$ 
and $1983 \leftarrow 2009$. The FAC used to estimate glacier area were the 'All' column found in Table 11. The fraction of area was rescaled so that 1900 was 1.0. Uncertainty was calculated for each year using the uncertainty associated with the FAC calculation from the partially overlapping datasets and the total area from each year (10).

$$
U=\frac{1}{2}\left(U_{i}(F A C+1)+A_{i} U_{f}\right)
$$

where the uncertainty from the initial area, $U_{i}$, and is the initial area, $A_{i}$, times the uncertainty of the final area, $U_{f}$. Results were tabulated in Table 13 and Figure 16.

Table 13 - Overall area change from 1900-2009 summarized using fractional area change values for individual years.

\begin{tabular}{ccc}
\hline \hline Year & $\begin{array}{c}\text { Estimated Area } \\
\left(\mathrm{km}^{2}\right)\end{array}$ & Fractional Area \\
\hline 1900 & $533.89 \pm 22.77$ & $1.00 \pm 0.04$ \\
1958 & $288.30 \pm 12.50$ & $0.54 \pm 0.04$ \\
1968 & $298.99 \pm 17.25$ & $0.56 \pm 0.06$ \\
1983 & $302.82 \pm 17.34$ & $0.57 \pm 0.06$ \\
1990 & $282.53 \pm 13.33$ & $0.53 \pm 0.05$ \\
1998 & $268.41 \pm 13.40$ & $0.50 \pm 0.05$ \\
2009 & $236.20 \pm 12.60$ & $0.44 \pm 0.05$
\end{tabular}




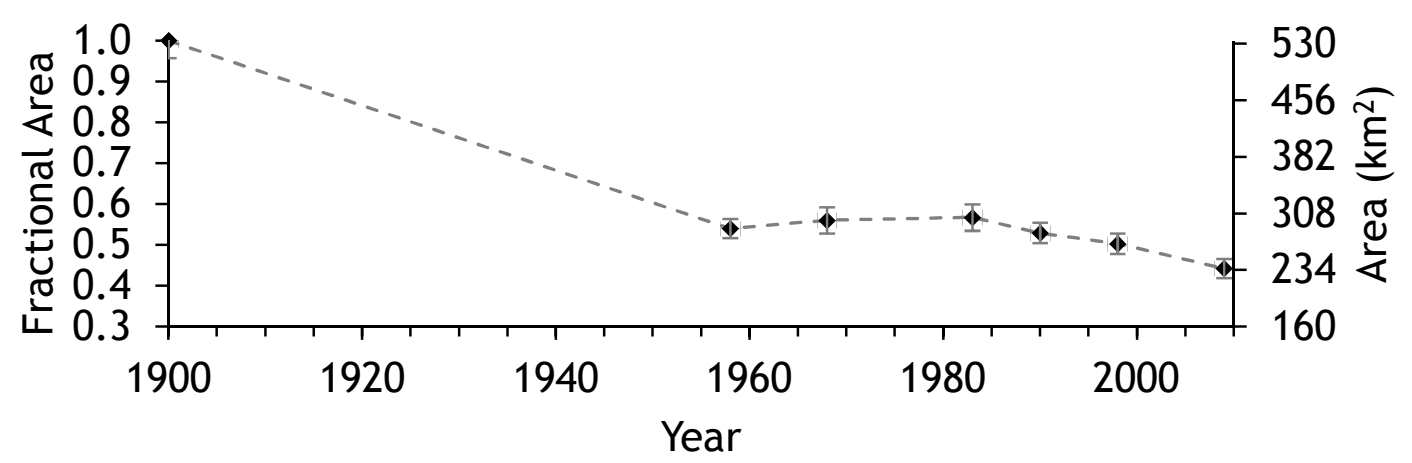

Figure 16 - Overall fractional area change from 1900-2009 from Table 11.

To compare the results for glacier change between the sets of identical glaciers to the datasets of similar glaciers both are plotted in Figure 17.
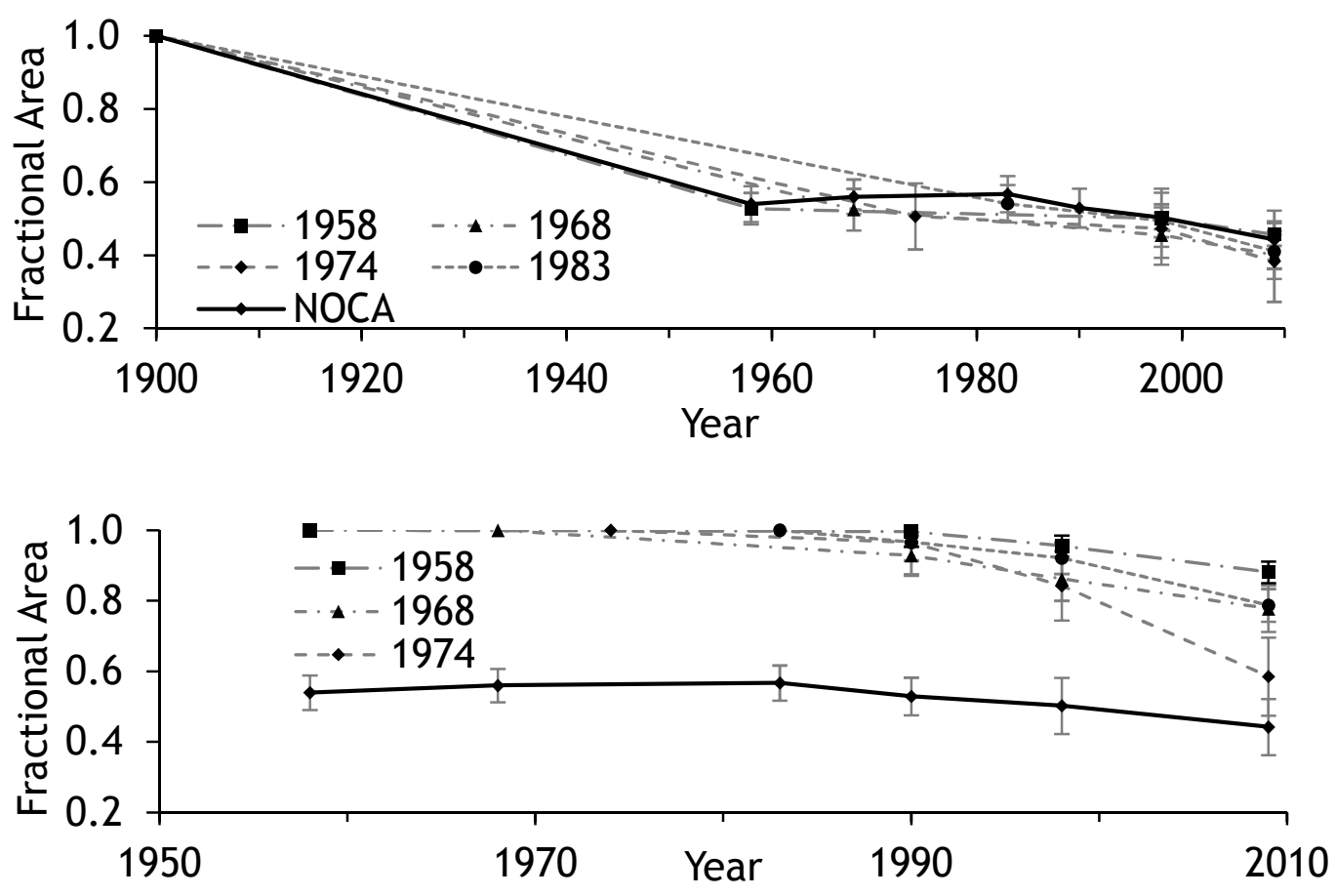

Figure 17 - Fractional area change of the North Cascades using identical glaciers (by different 24K year) compared to the partially overlapping estimate of glacier area change for the entire region (NOCA) from Figure 12. Top graph shows the comparison from 1900 using the group 1 data. The bottom graph shows the estimate relative to 1958 using group 2 data from Table 9. 
For the overall trends from 1900-2009, the overlapping datasets underestimate fractional area change from 1998-2009, -6\% compared to the identical glaciers (-9\% to $-19 \%)$ but still within uncertainty estimates. They also show less variability in the time period between 1958 and 1990 but is well within the uncertainty boundaries of the overall estimate. For group 2 of the same glaciers (24K year through 2009) the overlapping dataset is within uncertainty calculations.

While the glacier inventories of the North Cascades provides an estimate for glacier change across the region, the temporal density is lacking. To provide more detail over time, glacier data from Mount Baker and South Cascade Glacier (Krimmel, 1989, Bidlake and others, 2012) were used. I updated the record of glacier area on Baker by including the 2009 outline from the NAIP imagery (Table 14a, b, Table 15) and on South Cascade Glacier by digitizing the LIA outline as seen from the moraines visible on the 2009 imagery (http://ak.water.usgs.gov/glaciology/south_cascade/images/SCG_LIA_Topo.jp g) (Table 16). 
Table 14 (a) - Mount Baker temporal glacier area change data. Source, $\mathrm{S}$, is as follows: $1=\left(\right.$ Fountain and others, 2007a) $; 2=\left(O^{\prime} N e a l, 2005\right) ; 3=($ Harper, 1993); 4 = this thesis.

\begin{tabular}{cccccccc}
\hline \hline & \multicolumn{2}{c}{ Boulder } & \multicolumn{2}{c}{ Coleman } & \multicolumn{2}{c}{ Deming } \\
Year & $\begin{array}{c}\text { Area } \\
\left(\mathrm{km}^{2}\right)\end{array}$ & $\begin{array}{c}\text { Fractional } \\
\text { Area }\end{array}$ & $\begin{array}{c}\text { Area } \\
\left(\mathrm{km}^{2}\right)\end{array}$ & $\begin{array}{c}\text { Fractional } \\
\text { Area }\end{array}$ & $\begin{array}{c}\text { Area } \\
\left(\mathrm{km}^{2}\right)\end{array}$ & $\begin{array}{c}\text { Fractional } \\
\text { Area }\end{array}$ & $\mathrm{S}$ \\
\hline 1900 & $5.48 \pm 0.15$ & $0.15 \pm 1.00$ & $5.45 \pm 0.15$ & $0.15 \pm 1.00$ & $6.51 \pm 0.16$ & $1.00 \pm 0.02$ & 1 \\
1931 & $3.95 \pm 0.13$ & $0.13 \pm 0.72$ & & & $4.89 \pm 0.75$ & $0.75 \pm 0.03$ & 2 \\
1940 & $3.61 \pm 0.12$ & $0.12 \pm 0.66$ & $4.80 \pm 0.14$ & $0.14 \pm 0.88$ & $4.94 \pm 0.76$ & $0.76 \pm 0.03$ & 3 \\
1947 & $3.40 \pm 0.12$ & $0.12 \pm 0.62$ & $4.64 \pm 0.14$ & $0.14 \pm 0.85$ & $4.75 \pm 0.73$ & $0.73 \pm 0.03$ & 3 \\
1956 & $3.46 \pm 0.12$ & $0.12 \pm 0.63$ & & & $5.00 \pm 0.77$ & $0.77 \pm 0.03$ & 3 \\
1963 & $3.58 \pm 0.12$ & $0.12 \pm 0.65$ & $4.89 \pm 0.14$ & $0.14 \pm 0.90$ & $5.06 \pm 0.78$ & $0.78 \pm 0.03$ & 3 \\
1964 & & & & & & & 3 \\
1965 & & & $4.91 \pm 0.14$ & $0.14 \pm 0.90$ & $5.04 \pm 0.77$ & $0.77 \pm 0.03$ & 3 \\
1967 & $3.63 \pm 0.12$ & $0.12 \pm 0.66$ & $4.94 \pm 0.14$ & $0.14 \pm 0.91$ & $5.05 \pm 0.78$ & $0.78 \pm 0.03$ & 3 \\
1970 & $3.64 \pm 0.12$ & $0.12 \pm 0.66$ & $4.97 \pm 0.14$ & $0.14 \pm 0.91$ & $5.05 \pm 0.78$ & $0.78 \pm 0.03$ & 3 \\
1972 & & & $4.97 \pm 0.14$ & $0.14 \pm 0.91$ & & & 3 \\
1974 & $3.75 \pm 0.12$ & $0.12 \pm 0.68$ & $4.98 \pm 0.14$ & $0.14 \pm 0.91$ & $5.13 \pm 0.79$ & $0.79 \pm 0.03$ & 3 \\
1977 & $3.78 \pm 0.12$ & $0.12 \pm 0.69$ & $5.04 \pm 0.14$ & $0.14 \pm 0.93$ & $5.23 \pm 0.80$ & $0.80 \pm 0.03$ & 3 \\
1979 & $4.06 \pm 0.13$ & $0.13 \pm 0.74$ & $5.11 \pm 0.14$ & $0.14 \pm 0.94$ & $5.24 \pm 0.80$ & $0.80 \pm 0.03$ & 3 \\
1985 & & & $5.01 \pm 0.14$ & $0.14 \pm 0.92$ & $5.09 \pm 0.78$ & $0.78 \pm 0.00$ & 3 \\
1986 & $4.06 \pm 0.13$ & $0.13 \pm 0.74$ & & & & & 3 \\
1987 & & & $5.01 \pm 0.14$ & $0.14 \pm 0.92$ & $5.09 \pm 0.78$ & $0.78 \pm 0.03$ & 3 \\
1990 & & & $4.96 \pm 0.14$ & $0.14 \pm 0.91$ & $5.06 \pm 0.78$ & $0.78 \pm 0.03$ & 3 \\
1993 & $3.64 \pm 0.12$ & $0.12 \pm 0.66$ & $4.89 \pm 0.14$ & $0.14 \pm 0.90$ & & & 1 \\
1994 & & & & & & & 1 \\
2005 & $3.56 \pm 0.12$ & $0.12 \pm 0.00$ & & & & & 1 \\
2006 & $3.52 \pm 0.12$ & $0.12 \pm 0.64$ & $4.83 \pm 0.14$ & $0.14 \pm 0.89$ & $4.93 \pm 0.76$ & $0.76 \pm 0.03$ & 1 \\
2009 & $3.47 \pm 0.12$ & $0.12 \pm 0.63$ & $4.62 \pm 0.14$ & $0.14 \pm 0.85$ & $4.76 \pm 0.73$ & $0.73 \pm 0.03$ & 4
\end{tabular}


Table 14 (b) - Mount Baker temporal glacier area change data. Source, S, is as follows: $1=($ Fountain and others, $2007 \mathrm{a}) ; 2=\left(\mathrm{O}^{\prime} \mathrm{Neal}, 2005\right) ; 3=($ Harper, 1993); 4 = this thesis.

\begin{tabular}{cccccccc}
\hline \hline & \multicolumn{2}{c}{ Easton } & \multicolumn{2}{c}{ Rainbow } & \multicolumn{3}{c}{ Roosevelt } \\
Year & $\begin{array}{c}\text { Area } \\
\end{array}$ & Fractional & Area & Fractional & Area & Fractional & $\mathrm{S}$ \\
\hline 1900 & $4.19 \pm 0.13$ & $1.00 \pm 0.03$ & $3.02 \pm 0.11$ & $1.00 \pm 0.04$ & $5.10 \pm 0.14$ & $1.00 \pm 0.03$ & 1 \\
1931 & $3.21 \pm 0.11$ & $0.77 \pm 0.04$ & $2.62 \pm 0.10$ & $0.87 \pm 0.04$ & & & 2 \\
1940 & $2.75 \pm 0.11$ & $0.66 \pm 0.04$ & $1.67 \pm 0.08$ & $0.55 \pm 0.05$ & $3.86 \pm 0.12$ & $0.76 \pm 0.03$ & 3 \\
1947 & $2.65 \pm 0.10$ & $0.63 \pm 0.04$ & $1.70 \pm 0.08$ & $0.56 \pm 0.05$ & $3.74 \pm 0.12$ & $0.73 \pm 0.03$ & 3 \\
1956 & $2.59 \pm 0.10$ & $0.62 \pm 0.04$ & & & & & 3 \\
1963 & & & $1.75 \pm 0.08$ & $0.58 \pm 0.05$ & $3.96 \pm 0.13$ & $0.78 \pm 0.03$ & 3 \\
1964 & $2.68 \pm 0.10$ & $0.64 \pm 0.04$ & & & & & 3 \\
1965 & & & & & $3.91 \pm 0.13$ & $0.77 \pm 0.03$ & 3 \\
1967 & $2.72 \pm 0.11$ & $0.65 \pm 0.04$ & $1.78 \pm 0.08$ & $0.59 \pm 0.05$ & $3.93 \pm 0.13$ & $0.77 \pm 0.03$ & 3 \\
1970 & $2.76 \pm 0.11$ & $0.66 \pm 0.04$ & $1.78 \pm 0.08$ & $0.59 \pm 0.05$ & $3.95 \pm 0.13$ & $0.78 \pm 0.03$ & 3 \\
1972 & & & & & $3.99 \pm 0.13$ & $0.78 \pm 0.03$ & 3 \\
1974 & $2.80 \pm 0.11$ & $0.67 \pm 0.04$ & $1.83 \pm 0.09$ & $0.61 \pm 0.05$ & $4.05 \pm 0.13$ & $0.79 \pm 0.03$ & 3 \\
1977 & $2.83 \pm 0.11$ & $0.68 \pm 0.04$ & $1.83 \pm 0.09$ & $0.61 \pm 0.05$ & $4.13 \pm 0.13$ & $0.81 \pm 0.03$ & 3 \\
1979 & $2.88 \pm 0.11$ & $0.69 \pm 0.04$ & $1.94 \pm 0.09$ & $0.64 \pm 0.05$ & $4.14 \pm 0.13$ & $0.81 \pm 0.03$ & 3 \\
1985 & $2.85 \pm 0.11$ & $0.68 \pm 0.04$ & & & $4.02 \pm 0.13$ & $0.79 \pm 0.03$ & 3 \\
1986 & $2.85 \pm 0.11$ & $0.68 \pm 0.04$ & $1.83 \pm 0.09$ & $0.61 \pm 0.05$ & & & 3 \\
1987 & $2.85 \pm 0.11$ & $0.68 \pm 0.04$ & $1.82 \pm 0.09$ & $0.60 \pm 0.05$ & $4.03 \pm 0.13$ & $0.79 \pm 0.03$ & 3 \\
1990 & $2.85 \pm 0.11$ & $0.68 \pm 0.04$ & $1.81 \pm 0.09$ & $0.60 \pm 0.05$ & $3.95 \pm 0.13$ & $0.77 \pm 0.03$ & 3 \\
1993 & & & $1.80 \pm 0.09$ & $0.60 \pm 0.05$ & $3.92 \pm 0.13$ & $0.77 \pm 0.03$ & 1 \\
1994 & $2.82 \pm 0.11$ & $0.67 \pm 0.04$ & & & & & 1 \\
2005 & & & $1.73 \pm 0.08$ & & & & 1 \\
2006 & $2.74 \pm 0.11$ & $0.65 \pm 0.04$ & $1.70 \pm 0.08$ & $0.56 \pm 0.05$ & $3.90 \pm 0.13$ & $0.77 \pm 0.03$ & 1 \\
2009 & $2.68 \pm 0.10$ & $0.64 \pm 0.04$ & $1.68 \pm 0.08$ & $0.56 \pm 0.05$ & $3.65 \pm 0.12$ & $0.72 \pm 0.03$ & 4
\end{tabular}

Table 15 - Total and fractional area of all glaciers on Mount Baker. If there were missing values from Table $14(a, b)$ for any given year, the values were interpolated per glacier/per year.

\begin{tabular}{lllrll}
\hline Year & Area $\left(\mathrm{km}^{2}\right)$ & Fractional Area & Year & Area $\left(\mathrm{km}^{2}\right)$ & Fractional Area \\
\hline 1900 & $29.76 \pm 2.254$ & $1.00 \pm 0.08$ & 1977 & $22.85 \pm 0.736$ & $0.77 \pm 0.03$ \\
1931 & $23.75 \pm 0.779$ & $0.80 \pm 0.03$ & 1979 & $23.37 \pm 0.740$ & $0.79 \pm 0.03$ \\
1940 & $21.63 \pm 0.718$ & $0.73 \pm 0.03$ & 1985 & $22.87 \pm 0.739$ & $0.77 \pm 0.03$ \\
1947 & $20.88 \pm 0.703$ & $0.70 \pm 0.03$ & 1986 & $22.87 \pm 0.735$ & $0.77 \pm 0.03$ \\
1956 & $21.52 \pm 0.711$ & $0.72 \pm 0.03$ & 1987 & $22.80 \pm 0.737$ & $0.77 \pm 0.03$ \\
1963 & $21.91 \pm 0.720$ & $0.74 \pm 0.03$ & 1990 & $22.46 \pm 0.734$ & $0.75 \pm 0.03$ \\
1964 & $21.92 \pm 0.720$ & $0.74 \pm 0.03$ & 1993 & $22.12 \pm 0.400$ & $0.74 \pm 0.02$ \\
1965 & $21.93 \pm 0.718$ & $0.74 \pm 0.03$ & 1994 & $22.08 \pm 0.338$ & $0.74 \pm 0.02$ \\
1967 & $22.05 \pm 0.722$ & $0.74 \pm 0.03$ & 2005 & $21.71 \pm 0.242$ & $0.73 \pm 0.01$ \\
1970 & $22.15 \pm 0.724$ & $0.74 \pm 0.03$ & 2006 & $21.63 \pm 0.077$ & $0.73 \pm 0.00$ \\
1972 & $22.33 \pm 0.726$ & $0.75 \pm 0.03$ & 2009 & $20.86 \pm 0.076$ & $0.70 \pm 0.00$ \\
1974 & $22.54 \pm 0.733$ & $0.76 \pm 0.03$ & & &
\end{tabular}


Table 16 - South Cascade Glacier area change from 1900-2009. Source number is as follows: $1=2009$ NAIP imagery and interpretation; $2=$ Unpublished data (Krimmel); 3= (Elsberg and others, 2001); 4= (Krimmel 1989, 1993, 1994, 1995, 1997, 1996, 1998, 1999, 2000, 2001a, 2002b, Elsberg and others, 2001, Bidlake and others 2004, 2005, 2007, 2010, 2012), 5=2009 NAIP imagery and 7 = oblique aerial photograph (USGS).

\begin{tabular}{|c|c|c|c|c|c|c|c|}
\hline \multicolumn{8}{|c|}{ Fractional } \\
\hline Year & Area $\left(\mathrm{km}^{2}\right)$ & Area & $S$ & Year & Area $\left(\mathrm{km}^{2}\right)$ & Fractional Area & $S$ \\
\hline 1900 & $3.23 \pm 0.065$ & $1.00 \pm 0.0201$ & 1 & 1986 & $2.18 \pm 0.001$ & $0.68 \pm 0.0005$ & 3 \\
\hline 1928 & $2.85 \pm 0.057$ & $0.88 \pm 0.0201$ & 7 & 1987 & $2.17 \pm 0.001$ & $0.67 \pm 0.0005$ & 3 \\
\hline 1958 & $2.51 \pm 0.001$ & $0.78 \pm 0.0004$ & 2 & 1988 & $2.15 \pm 0.001$ & $0.67 \pm 0.0005$ & 3 \\
\hline 1961 & $2.43 \pm 0.001$ & $0.75 \pm 0.0004$ & 2 & 1989 & $2.13 \pm 0.001$ & $0.66 \pm 0.0005$ & 3 \\
\hline 1964 & $2.40 \pm 0.001$ & $0.74 \pm 0.0004$ & 2 & 1990 & $2.12 \pm 0.001$ & $0.66 \pm 0.0005$ & 3 \\
\hline 1967 & $2.35 \pm 0.001$ & $0.73 \pm 0.0004$ & 2 & 1991 & $2.10 \pm 0.001$ & $0.65 \pm 0.0005$ & 3 \\
\hline 1968 & $2.34 \pm 0.001$ & $0.72 \pm 0.0004$ & 2 & 1992 & $2.09 \pm 0.001$ & $0.65 \pm 0.0005$ & 4 \\
\hline 1969 & $2.33 \pm 0.001$ & $0.72 \pm 0.0004$ & 2 & 1993 & $2.08 \pm 0.001$ & $0.64 \pm 0.0005$ & 4 \\
\hline 1970 & $2.32 \pm 0.001$ & $0.72 \pm 0.0004$ & 3 & 1994 & $2.05 \pm 0.001$ & $0.64 \pm 0.0005$ & 4 \\
\hline 1971 & $2.32 \pm 0.001$ & $0.72 \pm 0.0004$ & 3 & 1995 & $2.03 \pm 0.001$ & $0.63 \pm 0.0005$ & 4 \\
\hline 1972 & $2.32 \pm 0.001$ & $0.72 \pm 0.0004$ & 3 & 1996 & $2.02 \pm 0.001$ & $0.62 \pm 0.0005$ & 4 \\
\hline 1973 & $2.32 \pm 0.001$ & $0.72 \pm 0.0004$ & 3 & 1997 & $2.00 \pm 0.001$ & $0.62 \pm 0.0005$ & 4 \\
\hline 1974 & $2.31 \pm 0.001$ & $0.72 \pm 0.0004$ & 3 & 1998 & $1.97 \pm 0.001$ & $0.61 \pm 0.0005$ & 4 \\
\hline 1975 & $2.30 \pm 0.001$ & $0.71 \pm 0.0004$ & 3 & 1999 & $1.96 \pm 0.001$ & $0.61 \pm 0.0005$ & 4 \\
\hline 1976 & $2.30 \pm 0.001$ & $0.71 \pm 0.0004$ & 3 & 2000 & $1.95 \pm 0.001$ & $0.61 \pm 0.0005$ & 4 \\
\hline 1977 & $2.30 \pm 0.001$ & $0.71 \pm 0.0004$ & 3 & 2001 & $1.92 \pm 0.001$ & $0.60 \pm 0.0005$ & 4 \\
\hline 1978 & $2.28 \pm 0.001$ & $0.71 \pm 0.0004$ & 3 & 2002 & $1.92 \pm 0.001$ & $0.60 \pm 0.0005$ & 4 \\
\hline 1979 & $2.27 \pm 0.001$ & $0.70 \pm 0.0004$ & 3 & 2003 & $1.89 \pm 0.001$ & $0.59 \pm 0.0005$ & 4 \\
\hline 1980 & $2.26 \pm 0.001$ & $0.70 \pm 0.0004$ & 3 & 2004 & $1.82 \pm 0.001$ & $0.56 \pm 0.0005$ & 4 \\
\hline 1981 & $2.25 \pm 0.001$ & $0.70 \pm 0.0004$ & 3 & 2005 & $1.75 \pm 0.001$ & $0.54 \pm 0.0006$ & 4 \\
\hline 1982 & $2.24 \pm 0.001$ & $0.69 \pm 0.0004$ & 3 & 2006 & $1.74 \pm 0.001$ & $0.54 \pm 0.0006$ & 4 \\
\hline 1983 & $2.22 \pm 0.001$ & $0.69 \pm 0.0005$ & 3 & 2007 & $1.73 \pm 0.001$ & $0.54 \pm 0.0006$ & 4 \\
\hline 1984 & $2.20 \pm 0.001$ & $0.68 \pm 0.0005$ & 3 & 2009 & $1.72 \pm 0.010$ & $0.53 \pm 0.0058$ & 6 \\
\hline 1985 & $2.19 \pm 0.001$ & $0.68 \pm 0.0005$ & 3 & & & & \\
\hline
\end{tabular}

Over the past century, the glaciers on Mount Baker have gone through one advance/retreat cycle (Figure 18). Between 1900 and 2009 the six glaciers on Mount Baker fluctuated in the following three phases 1) Rapid retreat from 1900 through the 1950s; 2) Approximately 30 years of advance ending around 1980; 3) Retreat through 2009. The individual glaciers are highly correlated with each other but the magnitude of change particularly from 1900 to about 1950 differ greatly. In contrast, South Cascade Glacier has more or less 
retreated throughout the entire period, except for a brief period of stability and perhaps slight advance in the early 1970s (Figure 18).
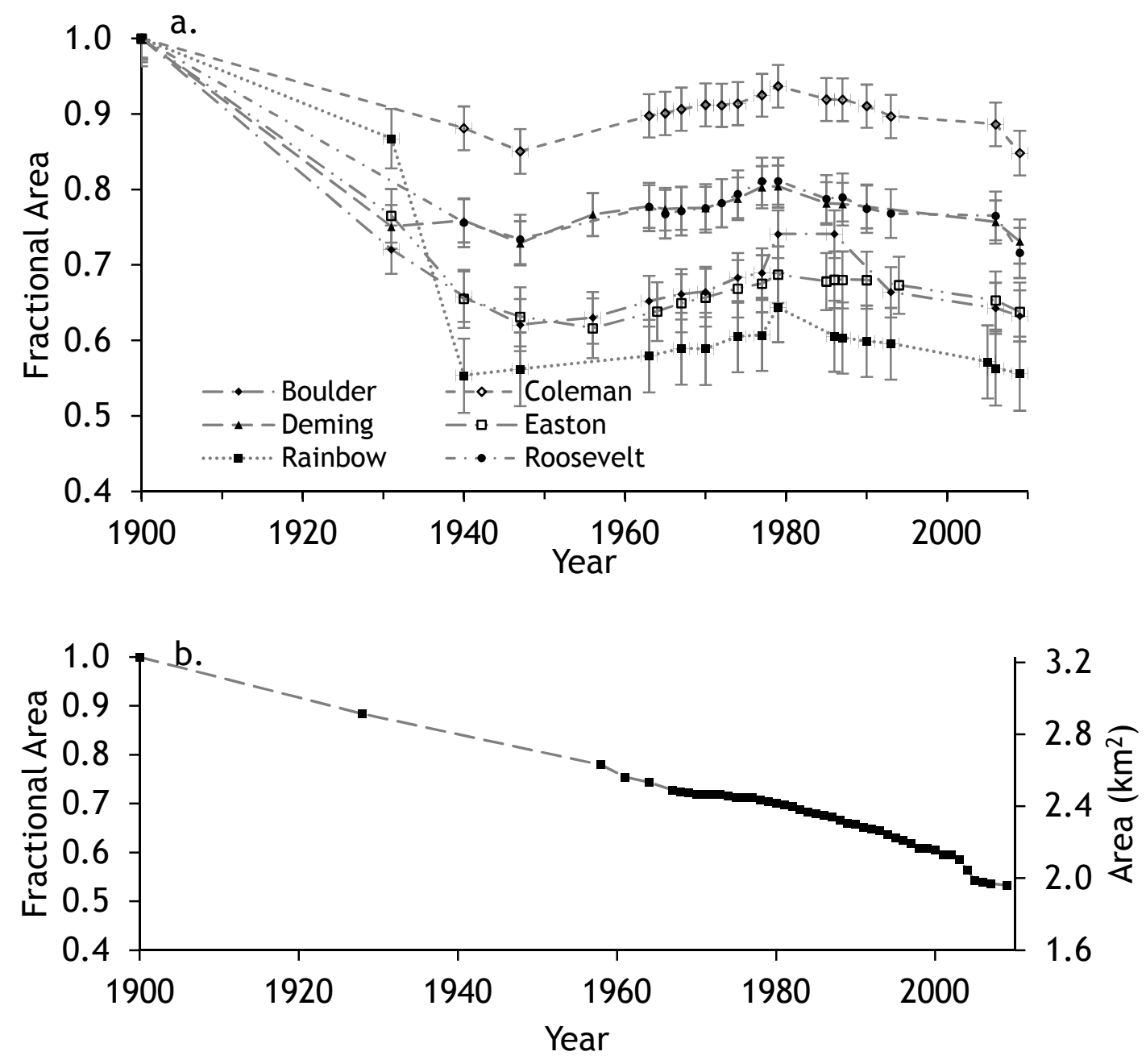

Figure 18 - Area change for glaciers on Mount Baker (a) and South Cascade Glacier (b). 

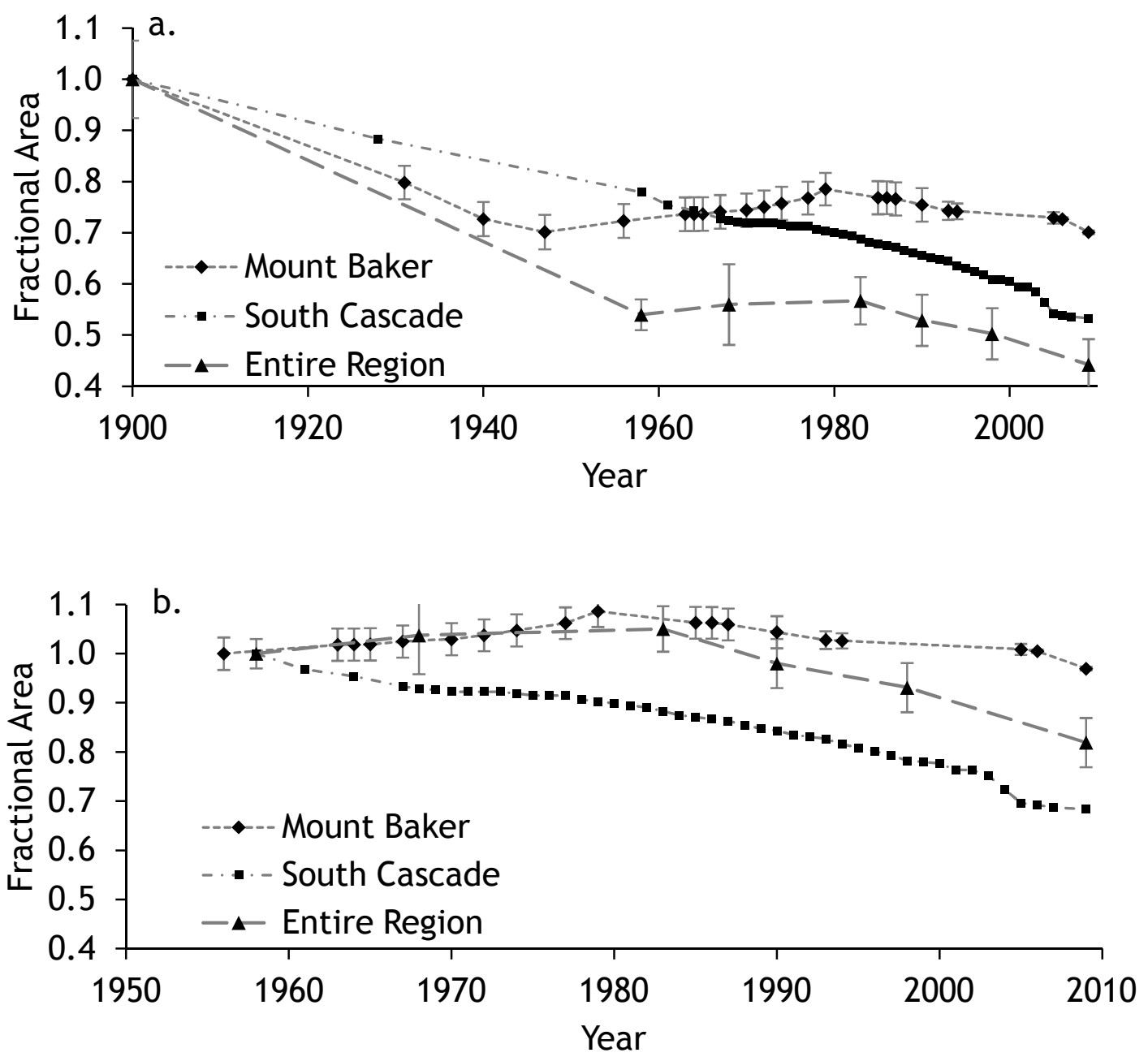

Figure 19 - Fractional area over the past century (a) for the total of all glaciers on Mount Baker, South Cascade and the total estimate of the North Cascades including Mount Baker. (b) is similar to (a) but only for the last 60 years, with the same vertical scale.

The glaciers from the entire region using three different temporal datasets show that the entire region is responding in similar ways, but with different magnitudes. Overall, the entire North Cascades and Mount Baker show similar trends over the past century following that described earlier for Mount Baker (Figure 19). South Cascade Glacier generally follows the other glaciers but it 
retreated less from 1900-1958 and retreated more from 1958 to 2009. During the 1960s-1970s the glacier slowed retreat but never stabilized or advanced. Since the 1970s its retreat was much faster than the other glaciers.

Three monitoring programs have been measuring mass balance at 15 glaciers in the North Cascades. The longest running mass balance program is at South Cascade Glacier from 1958 - present. The monitored glaciers are distributed spatially throughout the region and have different areas (Figure 20).

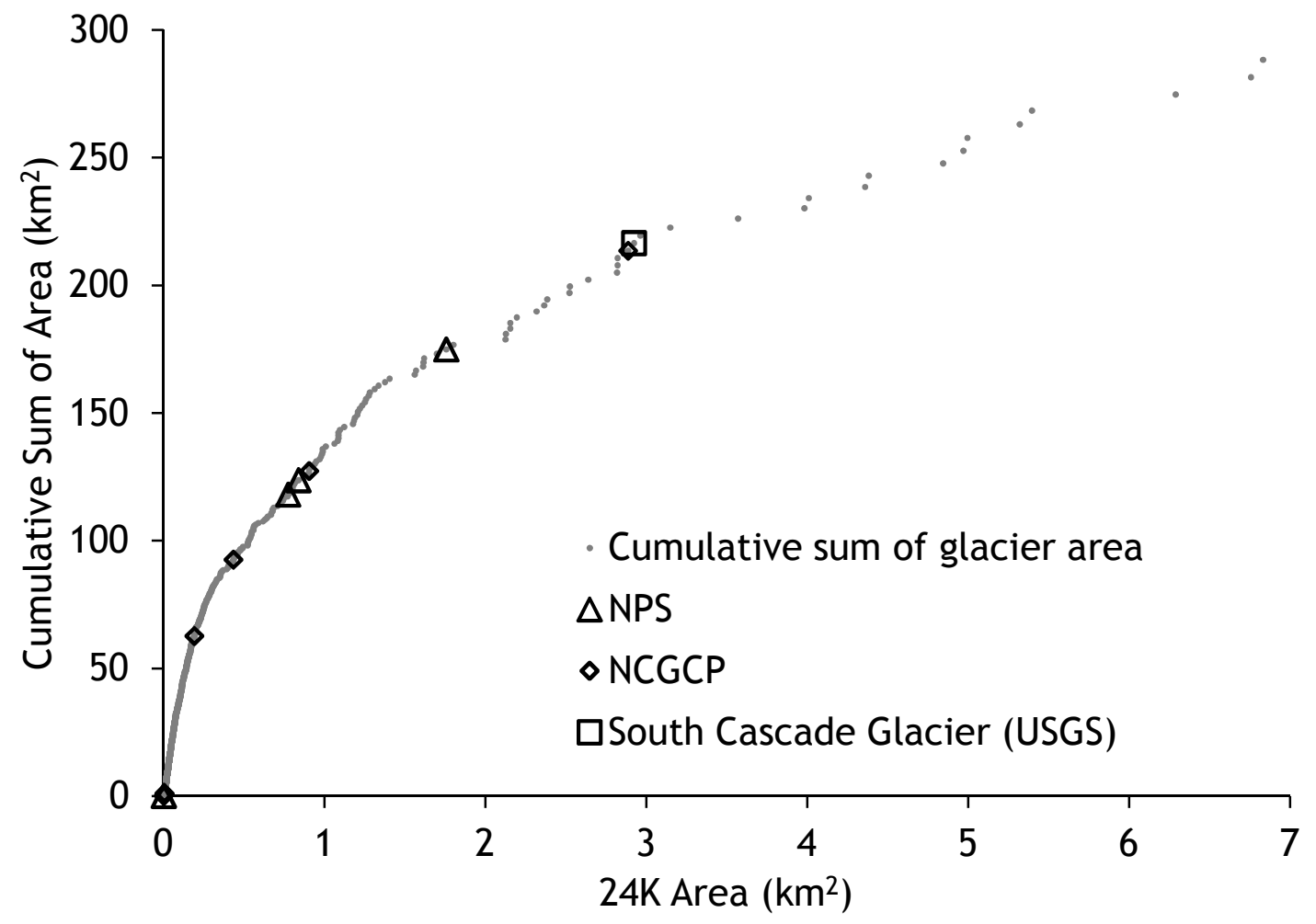

Figure 20 - Cumulative area sum for the North Cascades 24K (Chapter 2) with monitored glaciers indicated by points. 
Mass balance on South Cascade Glacier has an overall negative mass balance trend since 1958 consistent with area change (Figure 21). There was a brief period of positive mass balance in the 1970s, but since 1977 the mass balance has been very negative (Bidlake and others, 2012). A mass balance study in the North Cascades from 1984-2006 shows that the cumulative mass balance was negative through most of the 1980s, followed by a period of stability/growth during the mid-1990s and since the late 1990s, the cumulative mass balance has been very negative (Pelto, 2008) (Figure 22). Other monitored glaciers in the North Cascades National Park also show a similar trend of stability in the 1990s followed by decline in the late 1990s to 2009 (Riedel \& Larrabee, 2011) (Figure 23). The comparison between the area change and the mass balance shows that there is an overall negative mass loss of glacial ice that can be seen both in the direct glacier measurements and in large negative area change in the glacier inventories. The mass balance trends in the NPS and NCGCP monitored glaciers are less when compared to South Cascade Glacier and are more reflective of regional glacier change, and South Cascade Glacier is an outlier. 


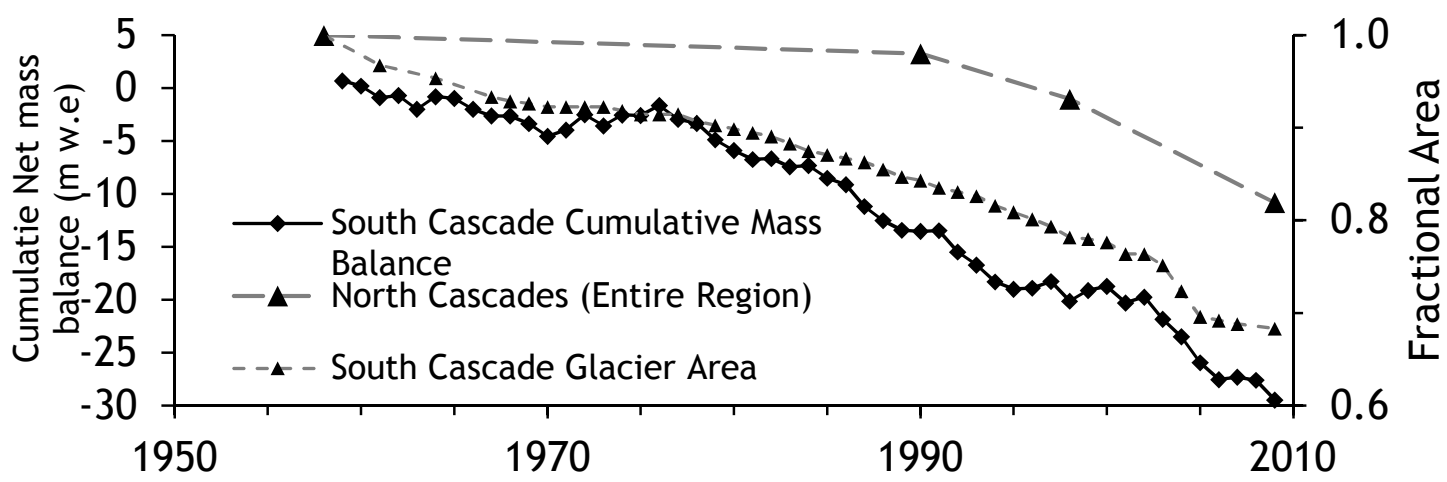

Figure 21 -Cumulative nest mass balance at South Cascade Glacier from 1958 2009. Fractional area of South Cascade Glacier and the entire North Cascades (from 1958) are also included for comparison.

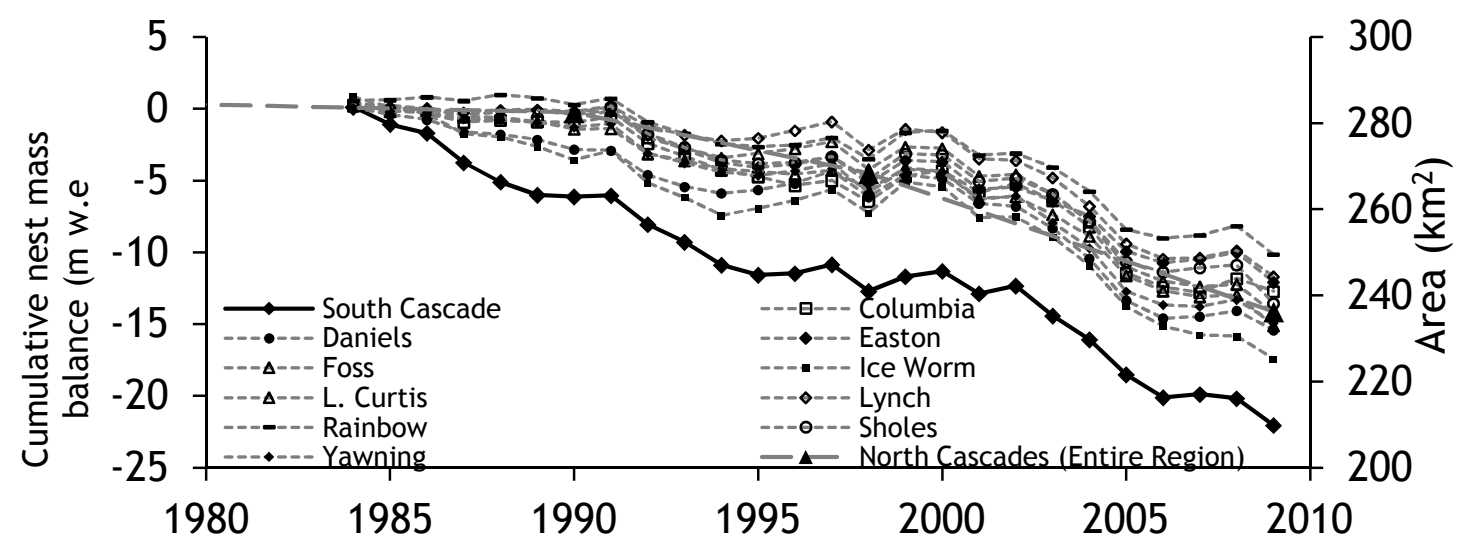

Figure 22 - Cumulative net mass balance of the North Cascades Glacier Climate Project monitored glaciers since 1984. The total glacier coverage in the North Cascades is included for comparison.

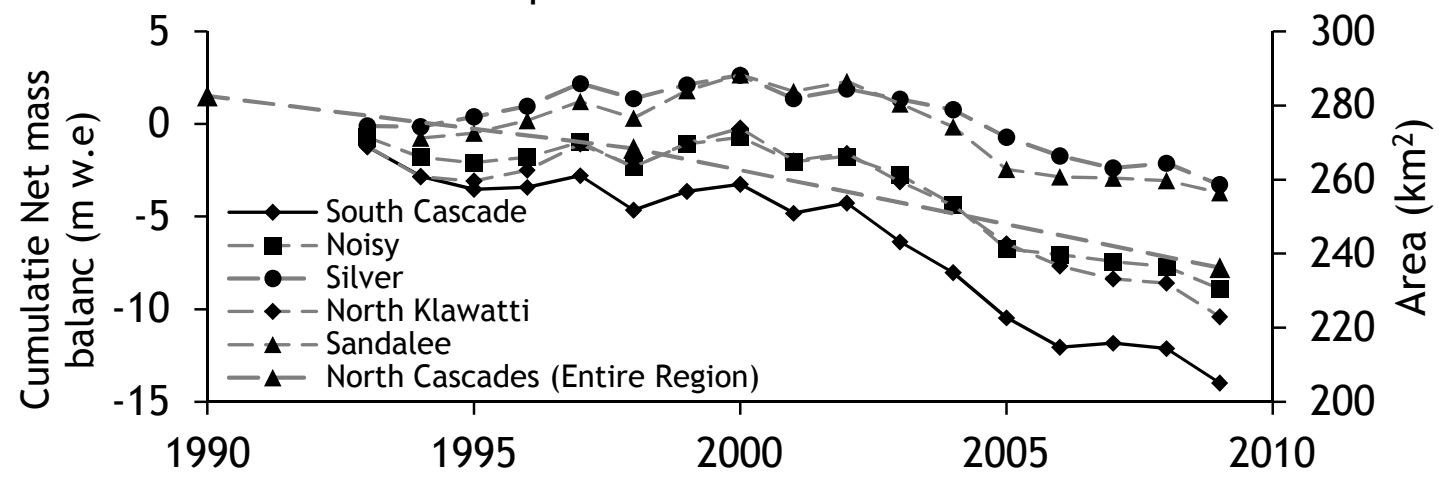

Figure 23 - Cumulative net mass balance of the North Cascades National Park monitored glaciers since 1993. The total glacier coverage in the North Cascades is included for comparison. 


\section{Discussion \& Conclusions}

In the North Cascades glacier area lost more than half $(-56 \% \pm 3 \%)$ since the LIA $(\sim 1900)$ to 2009. All estimates of fractional glacier area loss in percent are relative to 1900 , except when otherwise stated. Most of that loss occurred in the first half of the century (1900-1958) when almost half of the area was lost $(-46 \% \pm 3 \%)$. In the latter half century $1958-2009$ an additional $10 \%$ was lost. These results are consistent with Granshaw and Fountain (2006) who found glacier area loss of 7\% (1958-1998) within the North Cascades Park Complex. The period from 1958 to 1990 was relatively stable with area change less than overall uncertainty. Generally, smaller glaciers lost more fractional area than larger and smaller glaciers also exhibit more variability in change. Most of the variability could be explained by the area change values being within overall area change uncertainty.

The differences in area change between South Cascade, Mount Baker and the entire region from 1900 to 1958 shows that Mount Baker lost about 30\% while the region as a whole lost more than half and South Cascade glacier only lost about 20\% (Figure 19). Between 1958 and 1980s, the glaciers on Mount Baker and the entire region were stable, while South Cascade has only a brief period of stability in the early 1970 s. Since that time the glacier has been rapidly retreating.

The long term mass balance monitoring programs in the North Cascades (South Cascade, NPS, and NCGCP) all show similar trends of negative mass 
balance, with the exception of South Cascade which is more negative than the other monitored glaciers. These generally negative mass balances are consistent with the negative area change values.

My results in the North Cascades $(-56 \%, 1900-2009)$ are consistent with other studies of glacier area change over the past century across the western United States. On Mount Rainier on the southern end of the North Cascades, the glaciers changed by -22\% between 1913 and 1994 (Nylen, 2004); and a little further south $(70 \mathrm{~km})$ Mount Adams changed by 49\% from 1904 to 2006 (Sitts and others, 2010); in Oregon, glaciers on Mount Hood have changed by $-34 \%$ since 1907-2004 (Jackson \& Fountain, 2007). The Sierra Nevada shows that glacier area has a 55\% area loss between 1903 and 2004 (Basagic \& Fountain, 2011), the Front Range of Colorado, in Rocky Mountain National Park - 40\% change 1909-2004 (Hoffman and others, 2007). The decadal changes are similar as well.

These more detailed studies from the western United States have a similar trend to the studies from around the world, however the magnitude of the trends is different. From 1919 to 2006, glaciers in the Canadian Rocky Mountains decreased by $40 \% \pm 5 \%$ (Tennant and others, 2012). In Switzerland, glacier area change was slightly negative (-2\%) from $1850-1973$. In the Canadian Cordillera from 1951-2001, the glaciers shrunk by -15\% (North Cascades - $18 \%$ from 1958-2009), while the glaciers in the Columbia Mountains and Coast Mountains decreased by 5\% during 1951-2001 and 1964-2001, respectively 
(DeBeer \& Sharp, 2007). In Switzerland from 1973-1998 there was -6\% glacier change and overlapping that period from 1985-1998, -14\% glacier area change (Paul, 2004). The magnitude of recent glacier area change is similar to the North Cascades. On a global scale, a mass balance synthesis, 1961-2004, shows that until 1970 glacier mass balance was about zero, but since then the balance has been negative (Kaser and others, 2006). Like my results small glaciers exhibit a wider range of area change values, than larger glaciers. Also, in Switzerland, smaller glaciers showed more variability in area change than the larger glaciers.

In conclusion, glacier area in the North Cascades has decreased by more than half $(-56 \% \pm 3 \%)$ from $1900-2009$. Most of the area loss occurred in the first half of the century from 1900 to 1958 with $46 \%$ of glacier area loss. The period from 1958 to 1990 the glacier area was stable (only $1 \%$ glacier shrinkage), and since 1990 the glaciers have lost an additional 9\% of glacier area. Smaller glaciers have more variability in fractional area change and most of the change is within uncertainty estimates. The overall regional trends are similar to the long term temporal data from Mount Baker and South Cascade Glacier. 


\section{Chapter 4 - Climate and Topographic Analysis}

Introduction

The purpose of this chapter is to examine the response of glaciers over the past century to climate variations (precipitation and air temperature) and to local topography. Comparison with seasonal air temperature and precipitation trends may indicate which season affects glacier area change more than others. For example, in the Sierra Nevada and Rocky Mountains, glacier area retreat was significantly correlated with warmer spring and summer temperatures (Basagic \& Fountain, 2011, Hoffman and others, 2007). Local topography plays an important role in glacier change by enhancing or diminishing the effects of climate (Graf, 1976). Previous studies in the North Cascades found no significant correlation between area change and topographic variables including aspect, slope and elevation (Granshaw \& Fountain, 2006). However, in the Sierra Nevada, less area shrinkage was correlated with greater headwall height as glaciers retreating into areas with less annual solar insolation (Basagic \& Fountain, 2011). In British Columbia, glaciers with little to no change were found at higher elevations, with steeper slopes, and less solar radiation while shrinking glaciers were found at lower elevations, with lower slopes, and higher solar radiation (DeBeer \& Sharp, 2009).

A large-scale climate variation such as the PDO influences temperature and precipitation patterns in the North Cascades. PDO (Pacific Decadal Oscillation), is an index of the North Pacific sea surface temperature (SST) 
variability, pole ward of 30N, (Mantua and others, 1997)

(http://jisao.washington.edu/pdo/) (Figure 24). A warm phase PDO causes to below-average snowpack and streamflow in the West, and a cool phase PDO causes an above average effect on snowpack and streamflow (Munn, 2002, Bitz \& Battisti, 1999, Mote, 2005). McCabe and Dettinger (2002) showed that PDO explains year to year variation in snowpack better than ENSO.

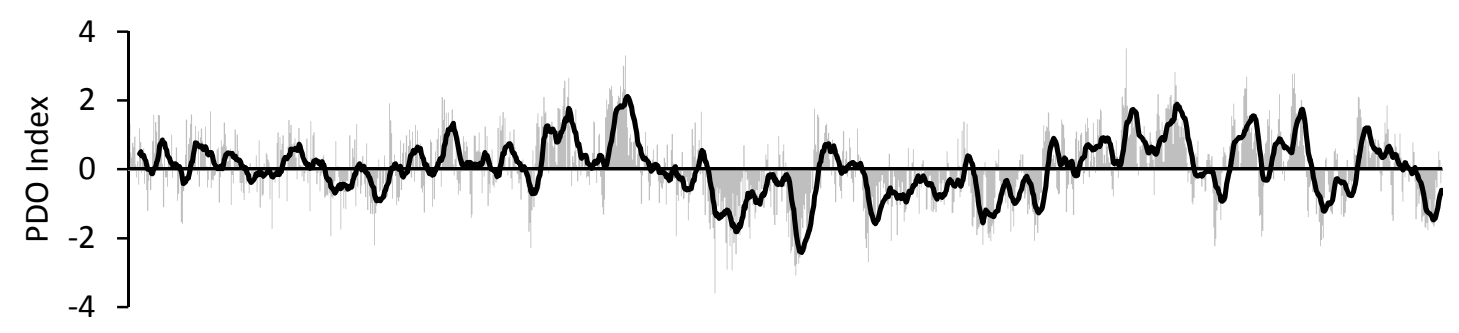

Figure 24 - Monthly PDO index values from 1900-2009 with a one year moving average (dark line).

\section{Methods}

The fractional area change data is from Chapter 3 - Table 11 and air temperature and precipitation data were acquired from the Parameterelevation Regression on Independent Slopes Model (PRISM) (http://www.prism.oregonstate.edu). The data uses climate stations to calculate a continuous, gridded dataset which consists of monthly maximum and minimum air temperatures and precipitation (Di Luzio and others, 2008). PRISM data are available from 1900 to 2006 at a $2 \mathrm{~km}$ grid and 2007-2009 at a 4 $\mathrm{km}$ grid. The centroid of each glacier was used to extract PRISM data values for each individual glacier. Because of the large grid size compared to the often 
smaller glaciers, identical climates are identified since many glaciers intersect the same grid cell.

Seasonal climates were calculated from the mean-monthly climate data. How to divide the year into seasons (natural, cultural) is open to question. Harper (1993) in his study on Mount Baker and Granshaw (2002) divided the year into two seasons, accumulation (Oct - April), and ablation (May - Sept) in an attempt to match the glacial cycle of mass gain/loss. Basagic and Fountain (2011) and Hoffman and others (2007) used a four season approach, a core winter and summer with two transition seasons of spring and autumn. These latter two studies found spring warming to be highly correlated with glacier shrinkage. To provide a similarly nuanced perspective on the seasonal effects of climate variation, I too divide the year into four seasons.

For a regional climate trend analysis, I used the Mann-Kendall nonparametric test to determine if a trend (increasing or decreasing) exist. The Mann-Kendall detects trends over time and has been used in both streamflow and climate data analysis (Chang and others, 2012, Pellicciotti and others, 2010, Yue and others, 2002) and is useful in detecting monotonic trends over time. The null hypothesis is that there is no trend for a given time series. Significant trends are reported at the $95 \%$ confidence level. In addition to the Mann-Kendall test, a regression analysis was included to determine the rate and significance of a linear trend at the $95 \%$ confidence level. Based on the intervals between glacier inventories (Chapter 3), the intervals for regional 
climate analysis are 1900-2009, 1900-1958, 1958-2009, 1958-1990 and 19902009.

For the topographic analysis, I examined the slope, elevation, aspect and insolation for each glacier and derived the mean value for each factor in ArcGIS using zonal statistics. Aspect was recalculated as northness and eastness to avoid the issue of a circular compass. Northness was calculated by taking the cosine of mean aspect, with the result being a value between 1 and -1 with " 1 " being true north and "-1" being true south. Eastness was calculated by taking the sine of mean aspect, with the result being "1" as true east. The mean annual insolation value for each glacier outline was derived from the solar radiation grid which represents the direct incoming solar radiation per grid cell in units of watts $/ \mathrm{m}^{2}$. The topographic analysis was divided into three separate groups, all glaciers, area greater than $0.1 \mathrm{~km}^{2}$ and area less than $0.1 \mathrm{~km}^{2}$ because the smaller glaciers have a lot of variability in fractional area change that could influence any trends.

A Pearson product-moment correlation and a non-parametric Spearman rank correlation were calculated to determine the correlation between the topographic and climate variables and fractional area change for individual glaciers. The two different correlation coefficients were used because of their different properties. The Pearson test assumes a normal distribution and equal variances, and it is sensitive to outliers because the correlation is based on how close the correlation follows a linear distribution. The Spearman test has 
relatively few assumptions and is not as sensitive to outliers in the data because the test statistic is derived by creating a ranked pair of values. It is also used for small sample sizes and non-normal data. The significance is reported at the $95 \%$ confidence level.

Since it is likely that multiple climate and topographic variables are correlated with fractional area change, a multiple regression analysis is calculated. The slope of the maximum air temperature for each glacier for each time period was used instead of average temperature in the multiple regression analysis to account for the rate of temperature change over time. The multiple regression analysis will be done on three different groups of area change data, 1900-2009, 1900-1958 and 1958-2009 to capture the temporal range of area change for the entire region.

\section{Results}

\section{Regional climate}

The extracted PRISM minimum temperature data showed some odd temperature anomalies that are most likely artifacts from different climate stations being used over certain time periods. A comparison with mean maximum and minimum temperature from the Snoquamie Falls climate station at 143 m elevation (http://www.wrcc.dri.edu/cgi-bin/cliMAIN.pl?wasnoq) showed that variations in the minimum temperature data from PRISM was not reflected in the Snoqualmie data suggesting an errors in the PRISM minimum temperature data. The maximum temperature data do not show the same 
anomalies and reflect similar variations in the Snoqualmie data therefore it will be used for the trend and correlation analysis. Although Tmin values is recognized to have some errors over the period of record, I justify the use in Table 17 that the errors are small compared to the long term average used to classify the seasons. The Tmin data will not be used in the analysis and air temperature changes will be based on Tmax.

The divisions between seasons are based on mean monthly air temperatures and precipitation averaged over the entire period of the PRISM record, 1900-2009 (Table 17). Core summer is defined as both minimum and maximum air temperature above $0^{\circ} \mathrm{C}$, average degree days above 400 , and precipitation less than $100 \mathrm{~mm}$ (June - Sept). These criteria infer warm sunny days. Core winter is defined as mean temperatures below $0^{\circ} \mathrm{C}$, degree days less than -75, and precipitation greater than $250 \mathrm{~mm}$ (Dec-March). These criteria infer cold, snowy days. The exception to this rule is March where maximum temperatures are slightly above freezing. The remaining months are transitional, spring (April - May) and autumn (October-November). 
Table 17 - Mean monthly values of minimum and maximum air temperature (Tmin, Tmax), ${ }^{\circ} \mathrm{C}$, Precipitation (Precip), mm, over the time period 1900-2009 derived from PRISM data. The numbers of degree days (DD) are calculated based on a 30-day month and assignment into seasonal category.

\begin{tabular}{lrrcrrl}
\hline \hline Month & $\begin{array}{c}\text { Mean } \\
\text { Tmin }\end{array}$ & $\begin{array}{r}\text { Mean } \\
\text { Tmax }\end{array}$ & $\begin{array}{c}\text { Mean of Tmin } \\
\text { and Tmax }\end{array}$ & Precip & $\begin{array}{c}\text { Degree } \\
\text { Days }\end{array}$ & Season \\
\hline October & 0.7 & 7.9 & 4.3 & 240.3 & 259.2 & Autumn \\
November & -4.1 & 1.0 & -1.6 & 368.2 & -94.0 & Autumn \\
December & -6.2 & -2.2 & -4.2 & 393.8 & -253.3 & Winter \\
January & -6.8 & -2.4 & -4.6 & 370.0 & -275.7 & Winter \\
February & -7.0 & -0.3 & -3.6 & 274.8 & -217.5 & Winter \\
March & -5.6 & 2.8 & -1.4 & 234.1 & -83.1 & Winter \\
April & -2.7 & 7.3 & 2.3 & 147.6 & 138.1 & Spring \\
May & 0.7 & 11.4 & 6.1 & 108.7 & 363.5 & Spring \\
June & 2.5 & 14.0 & 8.3 & 86.9 & 495.8 & Summer \\
July & 5.3 & 18.5 & 11.9 & 51.7 & 713.8 & Summer \\
August & 6.6 & 18.9 & 12.7 & 56.0 & 764.6 & Summer \\
September & 4.4 & 15.1 & 9.8 & 116.5 & 587.6 & Summer
\end{tabular}

Air temperatures significantly warmed from 1900 to 2009 (Table 18 and

Figure 25) with seasonal air temperature warming in winter and summer, the first half of the century (1900-1958) has significantly warming in annual and summer air temperatures. In the later half (1958-2009) temperature warmed in all seasons except autumn. From 1958-1990 spring air temperature warmed significantly. From 1990-2009, temperatures have not significantly increased. The regression results were similar for both the annual values seasonal values. 
Table 18 - Mann-Kendall (MK) and regression $\left(r^{2}\right)$ results for seasonal and annual temperature and precipitation trends for the time periods listed in the left hand column. Bold numbers indicate significance at the 95\% confidence level.

\begin{tabular}{|c|c|c|c|c|c|c|c|}
\hline & & & Annual & Autumn & Winter & Spring & Summer \\
\hline & 1900-2009 & & 4.16 & 1.06 & 3.93 & 1.41 & 4.15 \\
\hline & 1900-1958 & & 2.33 & 1.24 & 0.88 & 0.86 & 3.40 \\
\hline & 1958-2009 & MK & 3.95 & 1.52 & 3.31 & 3.21 & 2.99 \\
\hline$\stackrel{\varrho}{\Xi}$ & 1958-1990 & & 0.36 & 0.26 & -1.16 & 2.59 & 0.64 \\
\hline 은 & 1990-2009 & & 0.81 & 1.07 & 1.59 & -1.40 & 0.10 \\
\hline 足 & 1900-2009 & & 0.17 & 0.01 & 0.13 & 0.02 & 0.18 \\
\hline$\frac{\varepsilon}{1}$ & $1900-1958$ & & 0.09 & 0.01 & 0.02 & 0.01 & 0.19 \\
\hline & 1958-2009 & $r^{2}$ & 0.28 & 0.05 & 0.24 & 0.18 & 0.15 \\
\hline & $1958-1990$ & & 0.00 & 0.00 & 0.05 & 0.14 & 0.00 \\
\hline & 1990-2009 & & 0.03 & 0.09 & 0.21 & 0.08 & 0.00 \\
\hline & 1900-2009 & & -0.42 & 0.73 & -1.16 & 1.47 & 0.20 \\
\hline & 1900-1958 & & 0.64 & 0.41 & 0.52 & 0.50 & 0.81 \\
\hline & 1958-2009 & MK & -2.11 & -0.04 & -1.44 & -2.01 & -2.00 \\
\hline 음 & 1958-1990 & & -0.64 & -0.02 & -0.67 & -0.02 & 0.00 \\
\hline$\stackrel{0}{ \pm}$ & 1990-2009 & & -1.65 & -0.23 & -1.01 & -1.78 & -1.98 \\
\hline$\frac{n}{4}$ & $1900-2009$ & & 0.00 & 0.00 & 0.01 & 0.03 & 0.00 \\
\hline$\underline{d}$ & 1900-1958 & & 0.01 & 0.00 & 0.01 & 0.01 & 0.01 \\
\hline$\underline{\alpha}$ & 1958-2009 & $r^{2}$ & 0.07 & 0.29 & 0.65 & 0.01 & 0.07 \\
\hline & $1958-1990$ & & 0.01 & 0.00 & 0.02 & 0.00 & 0.00 \\
\hline & 1990-2009 & & 0.16 & 0.02 & 0.06 & 0.11 & 0.13 \\
\hline
\end{tabular}

Precipitation exhibited no trend over the past century (Table 18 and

Figure 25). A decrease in precipitation was found in summer and spring from 1958 to 2009 and then again from 1990 to 2009. The regression correlations indicate that the linear trends for all periods are weak. 

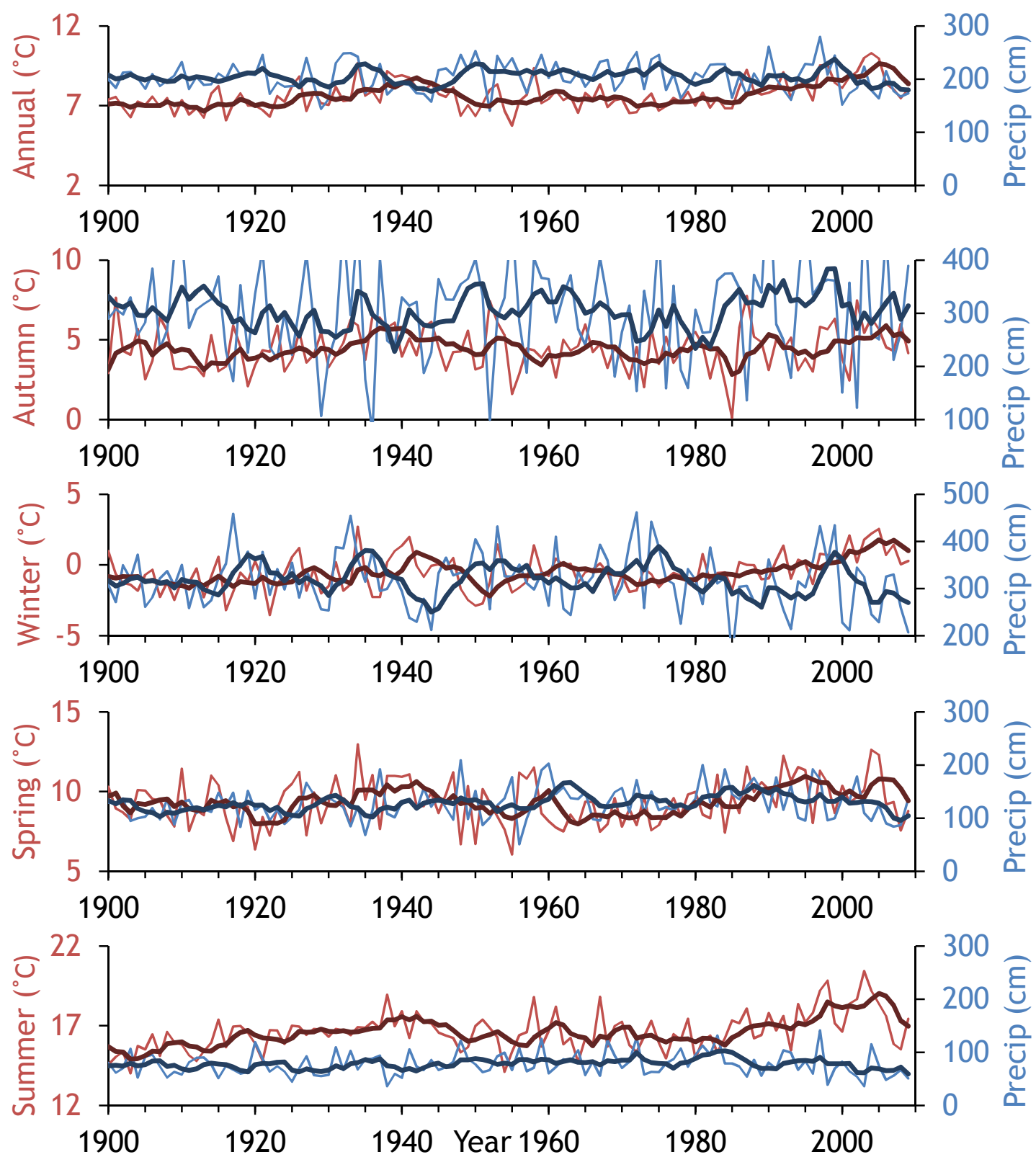

Figure 25 - Annual and seasonal maximum temperatures and precipitation for the North Cascades. The darker line is a 5-year running mean. Correlation of glacier area change and topographic/climate variables

To interpret both correlation tests, a positive correlation indicates that more area shrinkage (more negative) is associated with an increasing value of the variable in question. Conversely a negative correlation indicates that less 
area loss (less negative) is associated with a decreasing value of the correlative variable.

Over the century, 1900-2009, warmer temperature is significantly correlated with more fractional area loss in all seasons (Table 19); no significant correlation exists between precipitation and area change. Greater precipitation is significantly correlated to less fractional area loss from 19001958, 1958-1990, and 1968-2009 (Table 19). The opposite correlation between 1998 and 2009 shows that lower summer precipitation is associated with higher fractional area loss. Higher temperature is significantly correlated to higher fractional area loss in all seasons from 1983-2009 and 1998-2009. From 19582009 higher winter and summer temperatures were correlated with higher fractional area loss and from 1968-2009 only higher winter temperatures were significantly correlated (Table 19). 
Table 19 - Results of the correlation analysis between glacier area change and climate variables. The first group refers to the Pearson correlation coefficient $(r)$, and the second group is the Spearman rank correlation coefficient $\left(r_{s}\right)$. Bold numbers indicate significance at $95 \%$ confidence level. The seasonal values are as follows $\mathrm{A}=$ autumn, $\mathrm{Sp}=$ spring, $\mathrm{Su}=$ summer, $\mathrm{W}=$ winter. Red indicates significant positive trends, and blue is significant negative trends.

\begin{tabular}{|c|c|c|c|c|c|c|c|c|c|c|}
\hline \multirow{2}{*}{\multicolumn{2}{|c|}{ All Features }} & \multirow[b]{2}{*}{$\mathrm{n}$} & \multicolumn{4}{|c|}{ Precipitation } & \multicolumn{4}{|c|}{ Temperature } \\
\hline & & & A & Sp & Su & W & A & Sp & Su & W \\
\hline \multirow{8}{*}{ 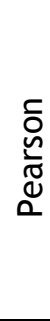 } & $1900-2009$ & 303 & 0.05 & 0.08 & 0.08 & 0.05 & -0.12 & -0.17 & -0.20 & -0.15 \\
\hline & $1900-1958$ & 128 & 0.23 & 0.20 & 0.21 & 0.26 & -0.14 & -0.07 & -0.14 & -0.06 \\
\hline & 1958-1990 & 100 & 0.34 & 0.35 & 0.37 & 0.37 & -0.25 & -0.19 & -0.16 & -0.06 \\
\hline & 1990-1998 & 189 & 0.11 & 0.00 & -0.02 & 0.07 & 0.06 & 0.02 & 0.08 & -0.01 \\
\hline & 1998-2009 & 517 & -0.05 & -0.07 & -0.21 & -0.03 & -0.26 & -0.23 & -0.18 & -0.24 \\
\hline & $1958-2009$ & 278 & 0.07 & 0.05 & 0.01 & 0.06 & -0.03 & 0.08 & -0.09 & -0.38 \\
\hline & 1968-2009 & 42 & 0.50 & 0.51 & 0.51 & 0.52 & -0.01 & 0.01 & -0.11 & -0.13 \\
\hline & 1983-2009 & 173 & 0.03 & -0.11 & -0.15 & 0.06 & -0.24 & -0.36 & -0.34 & -0.23 \\
\hline \multirow{8}{*}{ 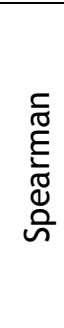 } & 2009 & 303 & 0.15 & 0.07 & 0.04 & 0.17 & -0.11 & -0.17 & -0.18 & -0.13 \\
\hline & -1958 & 128 & 0.14 & 0.14 & 0.15 & 0.17 & -0.10 & -0.14 & -0.12 & -0.06 \\
\hline & 1958-1990 & 100 & 0.34 & 0.36 & 0.35 & 0.37 & -0.13 & -0.11 & -0.11 & -0.04 \\
\hline & 1990-1998 & 189 & 0.13 & -0.00 & -0.01 & 0.05 & 0.12 & 0.12 & 0.12 & 0.06 \\
\hline & 1998-2009 & 517 & -0.16 & -0.14 & -0.25 & -0.09 & -0.26 & -0.21 & -0.20 & -0.24 \\
\hline & $1958-2009$ & 278 & 0.12 & 0.10 & 0.05 & 0.10 & -0.10 & 0.00 & -0.10 & -0.37 \\
\hline & 1968-2009 & 42 & 0.42 & 0.53 & 0.48 & 0.47 & -0.01 & 0.02 & -0.09 & -0.05 \\
\hline & $1983-2009$ & 173 & 0.02 & -0.09 & -0.15 & 0.04 & -0.18 & -0.24 & -0.26 & -0.21 \\
\hline
\end{tabular}

The above results of Table 19 were divided into two groups to see how glacier size affects the various climate correlations (Table 20). The results of the temperature correlation for the large glaciers are very similar to that of all the glaciers in Table 19, whereas the small glaciers are not. This suggests that temperature changes have a more effective influence on larger glaciers. Conversely, while changes in precipitation continue to have some effect on larger glaciers, perhaps at a somewhat less significance, on the smaller glaciers its correlation is greater suggesting that smaller glaciers are more responsive to changes in precipitation. 
Table 20 - Results of correlation analysis for the climate analysis divided into two groups for glaciers greater than and less than $0.1 \mathrm{~km}^{2}$. All other factors are the same as Table 19.

\begin{tabular}{|c|c|c|c|c|c|c|c|c|c|}
\hline \multirow{2}{*}{\multicolumn{2}{|c|}{ area $>0.1 \mathrm{~km}^{2}$}} & \multicolumn{4}{|c|}{ Precipitation } & \multicolumn{4}{|c|}{ Temperature } \\
\hline & & A & Sp & Su & W & A & Sp & Su & W \\
\hline & $1900-2009$ & 0.01 & 0.10 & 0.10 & 0.04 & -0.12 & -0.19 & -0.20 & -0.14 \\
\hline \multirow{7}{*}{ 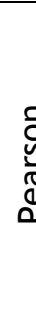 } & $1900-1958$ & 0.20 & 0.18 & 0.18 & 0.23 & -0.13 & -0.08 & -0.14 & -0.11 \\
\hline & $1958-1990$ & 0.23 & 0.29 & 0.27 & 0.31 & -0.22 & -0.21 & -0.17 & -0.11 \\
\hline & $1990-1998$ & 0.10 & -0.02 & -0.09 & 0.09 & -0.08 & -0.11 & -0.04 & -0.10 \\
\hline & $1998-2009$ & -0.08 & -0.06 & -0.18 & -0.05 & -0.11 & -0.01 & -0.15 & -0.38 \\
\hline & $1958-2009$ & 0.04 & -0.01 & -0.04 & 0.06 & -0.13 & -0.09 & -0.24 & -0.26 \\
\hline & $1968-2009$ & 0.47 & 0.38 & 0.41 & 0.45 & 0.01 & -0.05 & -0.04 & -0.01 \\
\hline & $1983-2009$ & 0.03 & -0.07 & -0.08 & 0.08 & -0.24 & -0.21 & -0.21 & -0.22 \\
\hline \multirow{8}{*}{ 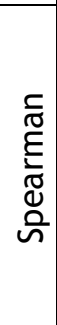 } & $1900-2009$ & 0.15 & 0.09 & 0.06 & 0.16 & -0.12 & -0.18 & -0.18 & -0.13 \\
\hline & $1900-1958$ & 0.15 & 0.16 & 0.16 & 0.18 & -0.11 & -0.15 & -0.13 & -0.10 \\
\hline & 1958-1990 & 0.11 & 0.17 & 0.14 & 0.20 & -0.19 & -0.11 & -0.12 & -0.08 \\
\hline & 1990-1998 & 0.13 & -0.09 & -0.13 & 0.02 & -0.07 & -0.06 & -0.04 & -0.10 \\
\hline & $1998-2009$ & -0.16 & -0.08 & -0.20 & -0.09 & -0.16 & -0.09 & -0.17 & -0.39 \\
\hline & $1958-2009$ & 0.04 & 0.08 & 0.02 & 0.06 & -0.11 & -0.07 & -0.23 & -0.14 \\
\hline & $1968-2009$ & 0.20 & 0.21 & 0.23 & 0.29 & 0.08 & 0.12 & -0.06 & 0.05 \\
\hline & $1983-2009$ & 0.01 & -0.02 & -0.05 & 0.05 & -0.22 & -0.16 & -0.21 & -0.21 \\
\hline \multirow{2}{*}{\multicolumn{2}{|c|}{ area $<0.1 \mathrm{~km}^{2}$}} & \multicolumn{4}{|c|}{ Precipitation } & \multicolumn{4}{|c|}{ Temperature } \\
\hline & & A & Sp & Su & W & A & Sp & Su & W \\
\hline \multirow{8}{*}{ 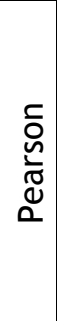 } & $1900-2009$ & 0.24 & -0.01 & -0.12 & 0.25 & -0.12 & -0.06 & -0.19 & -0.30 \\
\hline & $1900-1958$ & 0.75 & 0.73 & 0.75 & 0.74 & -0.04 & -0.35 & 0.07 & 0.66 \\
\hline & 1958-1990 & 0.36 & 0.34 & 0.40 & 0.36 & -0.23 & -0.11 & -0.09 & 0.03 \\
\hline & 1990-1998 & 0.20 & 0.05 & 0.06 & 0.11 & 0.17 & 0.14 & 0.20 & 0.08 \\
\hline & $1998-2009$ & -0.04 & -0.11 & -0.26 & -0.02 & 0.05 & 0.17 & -0.02 & -0.40 \\
\hline & $1958-2009$ & 0.12 & 0.09 & 0.05 & 0.10 & 0.15 & 0.16 & 0.07 & 0.05 \\
\hline & $1968-2009$ & 0.62 & 0.68 & 0.66 & 0.64 & 0.51 & 0.46 & 0.41 & 0.45 \\
\hline & $1983-2009$ & 0.04 & -0.33 & -0.35 & 0.03 & -0.27 & -0.25 & -0.05 & -0.24 \\
\hline \multirow{8}{*}{$\begin{array}{l}\frac{5}{\sigma} \\
\frac{\delta}{\delta} \\
\mathbb{\varpi} \\
\text { ñ }\end{array}$} & $1900-2009$ & 0.33 & 0.03 & -0.13 & 0.34 & -0.00 & -0.12 & -0.16 & -0.17 \\
\hline & $1900-1958$ & 0.59 & 0.46 & 0.44 & 0.59 & 0.33 & -0.29 & 0.12 & 0.61 \\
\hline & 1958-1990 & 0.42 & 0.44 & 0.44 & 0.41 & -0.06 & 0.01 & -0.02 & 0.09 \\
\hline & 1990-1998 & 0.28 & 0.14 & 0.16 & 0.15 & 0.32 & 0.31 & 0.32 & 0.28 \\
\hline & $1998-2009$ & -0.20 & -0.21 & -0.32 & -0.11 & -0.02 & 0.12 & -0.00 & -0.36 \\
\hline & $1958-2009$ & 0.13 & 0.06 & 0.03 & 0.10 & 0.11 & 0.15 & 0.07 & 0.07 \\
\hline & $1968-2009$ & 0.45 & 0.67 & 0.53 & 0.48 & 0.40 & 0.37 & 0.32 & 0.27 \\
\hline & $1983-2009$ & 0.06 & -0.31 & -0.42 & 0.01 & -0.30 & -0.28 & -0.07 & -0.28 \\
\hline
\end{tabular}

The effect of topographic setting is examined in Table 21. Smaller

glaciers were significantly correlated with more fractional area loss from 1900-

2009, 1900-1958, 1998-2009 and 1983-2009. Glaciers at lower elevations had

significant fractional area loss from 1900-2009, 1998-2009, 1990-1998 and 1983- 
2009. Steeper slopes were significantly correlated with more area loss from 1900-2009 and 1958-2009. There were no significant correlations with northness and eastness. Glaciers located more to the east (longitude) lost more area than western glaciers although southern glaciers lost more than northern glaciers in 1983-2009, and 1998-2009, and while northern-most glaciers lost more from 1958-1990. Glaciers with more solar insolation were significantly correlated with higher area change from 1900-1958.

Table 21 - Results of correlation analysis for glacier area change and topographic variables. Bold numbers indicate significance at $95 \%$ confidence level. Blue indicates a significant negative trend and red is a significant positive trend. The first group refers to the Pearson correlation coefficient ( $r$ ), and the second group is the Spearman rank correlation coefficient $\left(r_{s}\right) . N$ is the sample size. The topographic variables are (initial area $\left(A_{1}\right)$, mean elevation $\left(Z_{\text {MEAN }}\right)$, slope, northness, eastness, longitude, latitude, and insolation (Ins.).

\begin{tabular}{|c|c|c|c|c|c|c|c|c|c|c|}
\hline \multicolumn{2}{|c|}{ All Features } & $n$ & $A_{i}$ & $Z_{\text {MEAN }}$ & Mean & $\mathrm{N}$-ness & E-ness & Long. & Lat. & Ins. \\
\hline \multirow{8}{*}{ 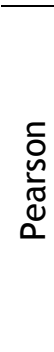 } & 1900-2009 & 303 & 0.36 & 0.25 & -0.16 & 0.02 & -0.06 & -0.02 & -0.02 & 0.05 \\
\hline & $1900-1958$ & 128 & 0.30 & 0.07 & -0.26 & -0.03 & 0.06 & -0.12 & 0.22 & -0.26 \\
\hline & $1958-1990$ & 100 & 0.14 & -0.09 & -0.01 & -0.01 & 0.06 & -0.19 & 0.34 & 0.23 \\
\hline & $1990-1998$ & 189 & 0.08 & 0.00 & -0.10 & 0.10 & 0.00 & -0.09 & -0.08 & -0.06 \\
\hline & 1998-2009 & 517 & 0.11 & 0.26 & 0.09 & -0.07 & -0.04 & 0.44 & -0.35 & 0.09 \\
\hline & $1958-2009$ & 278 & 0.10 & 0.14 & 0.10 & 0.03 & 0.03 & 0.00 & -0.01 & 0.12 \\
\hline & $1968-2009$ & 42 & 0.11 & -0.05 & 0.04 & -0.07 & 0.32 & -0.45 & -0.28 & -0.03 \\
\hline & $1983-2009$ & 173 & 0.23 & 0.34 & 0.16 & 0.04 & -0.06 & 0.24 & -0.18 & 0.10 \\
\hline \multirow{8}{*}{ 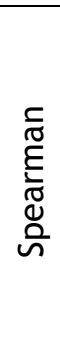 } & $1900-2009$ & 303 & 0.13 & 0.25 & -0.17 & 0.02 & -0.08 & 0.02 & 0.00 & 0.04 \\
\hline & $1900-1958$ & 128 & 0.08 & 0.14 & -0.25 & -0.03 & 0.04 & -0.01 & 0.14 & -0.23 \\
\hline & 1958-1990 & 100 & 0.18 & -0.08 & -0.05 & 0.01 & -0.02 & -0.12 & 0.12 & 0.13 \\
\hline & 1990-1998 & 189 & 0.09 & -0.06 & -0.11 & 0.11 & 0.01 & -0.09 & -0.05 & -0.09 \\
\hline & 1998-2009 & 517 & 0.06 & 0.26 & 0.06 & -0.09 & -0.06 & 0.44 & -0.39 & 0.10 \\
\hline & $1958-2009$ & 278 & 0.10 & 0.11 & 0.09 & 0.05 & -0.01 & -0.04 & -0.03 & 0.12 \\
\hline & $1968-2009$ & 42 & 0.20 & -0.06 & 0.08 & -0.15 & 0.30 & -0.41 & -0.27 & -0.07 \\
\hline & $1983-2009$ & 173 & 0.25 & 0.31 & 0.05 & 0.02 & -0.04 & 0.25 & -0.15 & 0.08 \\
\hline
\end{tabular}

The above results were divided into two groups to see how glacier size affects the influence of topographic variables (Table 22). For large glaciers (> 
$0.1 \mathrm{~km}^{2}$ ), a smaller initial area and higher slope are significantly correlated with more fractional area loss from 1900-2009, 1900-1958, 1998-2009, 19582009, and 1983-2009. Higher elevations were correlated with less area loss. Northness and eastness do not have any significant trends. Longitude and latitude and insolation have a combination of positive and negative significant trends over a few time periods. For the small glaciers $\left(<0.1 \mathrm{~km}^{2}\right)$ initial area, mean slope, northness and insolation did not have many significant trends. Elevation was significantly correlated (higher elevation, less loss) for the entire century (1900-2009) and the last 10 years (1998-2009). Glaciers that were most east-facing for 1900-1958 lost less fractional area. Longitude and latitude have mixed correlations. 
Table 22 - Results of correlation analysis for the topographic analysis divided into two groups for glaciers greater than and less than $0.1 \mathrm{~km}^{2}$. All other factors are the same as Table 21.

\begin{tabular}{|c|c|c|c|c|c|c|c|c|c|c|}
\hline \multicolumn{2}{|c|}{ Area $>0.1 \mathrm{~km}^{2}$} & $\bar{n}$ & $\overline{\overline{A_{i}}}$ & $Z_{\text {MEAN }}$ & Slope & N-ness & E-ness & Long. & Lat. & Ins. \\
\hline \multirow{8}{*}{ 등 } & $1900-2009$ & 276 & 0.42 & 0.24 & -0.18 & 0.01 & -0.06 & -0.04 & -0.03 & 0.07 \\
\hline & $1900-1958$ & 118 & 0.40 & 0.10 & -0.36 & 0.01 & 0.03 & -0.04 & 0.15 & -0.27 \\
\hline & $1958-1990$ & 55 & 0.14 & 0.01 & -0.14 & 0.23 & 0.05 & -0.06 & 0.10 & 0.46 \\
\hline & $1990-1998$ & 122 & 0.17 & 0.08 & -0.11 & 0.16 & -0.04 & 0.04 & -0.14 & -0.20 \\
\hline & 1998-2009 & 291 & 0.16 & 0.34 & 0.07 & -0.07 & -0.01 & 0.42 & -0.25 & 0.09 \\
\hline & $1958-2009$ & 152 & 0.12 & 0.18 & 0.13 & 0.06 & 0.07 & 0.15 & 0.00 & 0.22 \\
\hline & $1968-2009$ & 20 & 0.14 & 0.24 & 0.32 & -0.30 & 0.12 & -0.41 & -0.03 & -0.03 \\
\hline & 1983-2009 & 134 & 0.25 & 0.36 & 0.11 & 0.04 & -0.02 & 0.14 & -0.12 & 0.10 \\
\hline \multirow{8}{*}{ 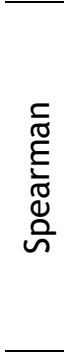 } & $1900-2009$ & 276 & 0.24 & 0.24 & -0.19 & 0.00 & -0.08 & 0.02 & 0.00 & 0.06 \\
\hline & $1900-1958$ & 118 & 0.26 & 0.15 & -0.30 & -0.01 & 0.03 & 0.02 & 0.15 & -0.25 \\
\hline & $1958-1990$ & 55 & 0.04 & 0.02 & -0.02 & 0.20 & 0.02 & 0.08 & -0.07 & 0.26 \\
\hline & $1990-1998$ & 122 & 0.23 & -0.01 & -0.11 & 0.14 & -0.04 & 0.09 & -0.14 & -0.17 \\
\hline & 1998-2009 & 291 & 0.16 & 0.33 & 0.00 & -0.08 & -0.07 & 0.46 & -0.36 & 0.13 \\
\hline & $1958-2009$ & 152 & 0.01 & 0.18 & 0.14 & 0.10 & 0.00 & 0.08 & -0.04 & 0.22 \\
\hline & $1968-2009$ & 20 & 0.12 & 0.14 & 0.23 & -0.31 & 0.15 & -0.23 & 0.05 & -0.09 \\
\hline & 1983-2009 & 134 & 0.30 & 0.31 & -0.04 & 0.03 & -0.02 & 0.13 & -0.05 & 0.03 \\
\hline \multicolumn{2}{|c|}{ Area $<0.1 \mathrm{~km}^{2}$} & $\mathrm{n}$ & $\overline{A_{i}}$ & $Z_{\text {MEAN }}$ & Slope & $\mathrm{N}$-ness & E-ness & Long. & Lat. & Ins. \\
\hline \multirow{8}{*}{ 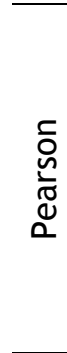 } & $1900-2009$ & 26 & -0.47 & 0.39 & -0.10 & 0.08 & -0.03 & 0.15 & -0.15 & -0.17 \\
\hline & $1900-1958$ & 10 & 0.25 & 0.15 & -0.07 & -0.29 & 0.72 & -0.87 & 0.80 & -0.38 \\
\hline & $1958-1990$ & 45 & 0.12 & -0.14 & 0.18 & -0.18 & 0.06 & -0.24 & 0.50 & 0.07 \\
\hline & 1990-1998 & 70 & 0.08 & -0.09 & -0.11 & 0.06 & 0.04 & -0.20 & -0.03 & 0.05 \\
\hline & $1998-2009$ & 229 & -0.10 & 0.17 & 0.12 & -0.07 & -0.07 & 0.47 & -0.46 & 0.11 \\
\hline & $1958-2009$ & 126 & -0.05 & 0.10 & 0.08 & 0.00 & -0.01 & -0.15 & -0.02 & 0.04 \\
\hline & $1968-2009$ & 22 & 0.41 & -0.25 & -0.06 & 0.08 & 0.43 & -0.53 & -0.46 & -0.03 \\
\hline & $1983-2009$ & 41 & 0.16 & 0.26 & 0.30 & -0.01 & -0.16 & 0.40 & -0.31 & 0.15 \\
\hline \multirow{8}{*}{ 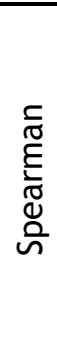 } & $1900-2009$ & 26 & -0.07 & 0.44 & -0.07 & 0.15 & -0.10 & 0.14 & -0.14 & -0.08 \\
\hline & $1900-1958$ & 10 & 0.31 & 0.21 & -0.10 & -0.36 & 0.69 & -0.71 & 0.48 & -0.36 \\
\hline & $1958-1990$ & 45 & 0.13 & -0.14 & -0.02 & -0.17 & -0.03 & -0.26 & 0.25 & 0.04 \\
\hline & 1990-1998 & 70 & 0.11 & -0.13 & -0.11 & 0.05 & 0.07 & -0.29 & 0.04 & 0.01 \\
\hline & $1998-2009$ & 229 & -0.12 & 0.19 & 0.13 & -0.09 & -0.06 & 0.44 & -0.42 & 0.09 \\
\hline & $1958-2009$ & 126 & -0.06 & 0.06 & 0.08 & 0.00 & -0.02 & -0.11 & -0.03 & 0.04 \\
\hline & $1968-2009$ & 22 & 0.36 & -0.15 & -0.07 & 0.01 & 0.40 & -0.43 & -0.53 & 0.00 \\
\hline & 1983-2009 & 41 & 0.12 & 0.24 & 0.33 & -0.02 & -0.15 & 0.48 & -0.42 & 0.23 \\
\hline
\end{tabular}

To explore the factors that may combine to influence glacier area change I employed a multiple regression model. The relative importance of each independent variable is represented by the standardized beta value (Table 23). I used a stepwise model which only includes significant factors in 
the final regression model. The multiple regression model for 1900-2009 with all topographic predictors, summer temperature and winter precipitation produced an $\mathrm{R}^{2}=0.162, \mathrm{p}<.001$. From 1900-2009, initial area and elevation explain about $16 \%$ of glacier area change. None of the other topographic or climate variables were significant. For the model from 1900-1958 resulted in an $R^{2}=0.230, p<.001$. Mean elevation, mean slope, spring and winter temperature changes significantly explain about $23 \%$ of the variability in glacier area change. The model from 1958 to 2009 produced an $R^{2}=0.164, p<.001$. The variables that produced the significant results include mean elevation, latitude, spring and summer precipitation and spring and summer temperature changes explain about $16 \%$ of glacier area change with the topographic and climate variables.

When the regression models are divided into large $\left(>0.1 \mathrm{~km}^{2}\right)$ and small glaciers $\left(<0.1 \mathrm{~km}^{2}\right)$, the regression models for larger glaciers have a higher $\mathrm{R}^{2}$ value. These models also include winter temperature as a significant factor. The regression models for the smaller glaciers show that location, both aspect and latitude/longitude were significant factors for glacier area change. 
Table 23 - Results of the multiple regression analysis. Only the significant standardized beta coefficients are reported below to show their relative weights of importance to the overall model. The seasonal values of precipitation and temperature change that were significant in each multiple regression model are as follows $\mathrm{A}=$ autumn, $\mathrm{Sp}=$ spring, $\mathrm{Su}=$ summer, $\mathrm{W}=$ winter. The topographic variables are (initial area $\left(A_{1}\right)$, mean elevation $\left(Z_{\text {MEAN }}\right)$, slope, northness ( $\mathrm{N}$-ness), eastness (E-ness), longitude, latitude, and insolation (Ins.).

\begin{tabular}{|c|c|c|c|c|c|c|c|c|}
\hline & \multicolumn{3}{|c|}{ All Glaciers } & \multicolumn{3}{|c|}{ Area $>0.1 \mathrm{~km}^{2}$} & \multicolumn{2}{|c|}{ "Area $<0.1 \mathrm{~km}^{2}$} \\
\hline & $\begin{array}{l}1900- \\
2009\end{array}$ & $\begin{array}{c}1900- \\
1958\end{array}$ & $\begin{array}{l}1958- \\
2009\end{array}$ & $\begin{array}{l}1900- \\
2009\end{array}$ & $\begin{array}{c}1900- \\
1958\end{array}$ & $\begin{array}{l}1958- \\
2009\end{array}$ & $\begin{array}{l}1900- \\
2009\end{array}$ & $\begin{array}{c}1900- \\
1958\end{array}$ \\
\hline $\mathrm{R}^{2}$ & 0.16 & 0.23 & 0.16 & 0.20 & 0.25 & 0.26 & 0.37 & 0.92 \\
\hline$A_{i}$ & 0.32 & 0.26 & & 0.38 & 0.30 & & & \\
\hline$Z_{\text {MEAN }}$ & 0.20 & & 0.20 & 0.17 & & 0.31 & & \\
\hline Slope & & -0.18 & & & -0.26 & & & \\
\hline $\mathrm{N}$-ness & & & & & & & & -0.40 \\
\hline E-ness & & & & & & & & \\
\hline Long. & & & & & & & -1.06 & -0.92 \\
\hline $\begin{array}{l}\text { Lat. } \\
\text { Ins. }\end{array}$ & & & -0.17 & & & 015 & & \\
\hline Precip & & & $\begin{array}{l}1.64 \mathrm{Sp} ; \\
-0.30 \mathrm{~S}\end{array}$ & & & $\begin{array}{l}1.52 \mathrm{Sp} \\
-1.22 \mathrm{~S}\end{array}$ & & \\
\hline Temp & & $\begin{array}{l}0.22 \mathrm{Sp} \\
-0.23 \mathrm{~W}\end{array}$ & $\begin{array}{c}-0.52 \mathrm{Sp} ; \\
0.23 \mathrm{~S}\end{array}$ & & $-0.18 W$ & $\begin{array}{l}-0.70 \mathrm{Sp} ; \\
0.38 \mathrm{~W}\end{array}$ & $-1.35 \mathrm{~S}$ & \\
\hline
\end{tabular}

Because there were not enough time intervals to generate a significant correlation between regional climate and the area change from (chapter 3: Table 13, Figure 16), they are qualitatively explored. The mean temperature and precipitation were calculated for 1900-1958; 1958-1968; 1968-1974; 19741983; 1983-1990; 1998-1998 and 1998-2009 (Table 24). Consistent with the regional trend analysis, the mean precipitation values are more or less consistent with some variability in mean autumn values. The temperature variations in all seasons show that the temperatures are getting warmer, and the warmer temperatures are associated with periods of glacier area decline (Figure 26). 

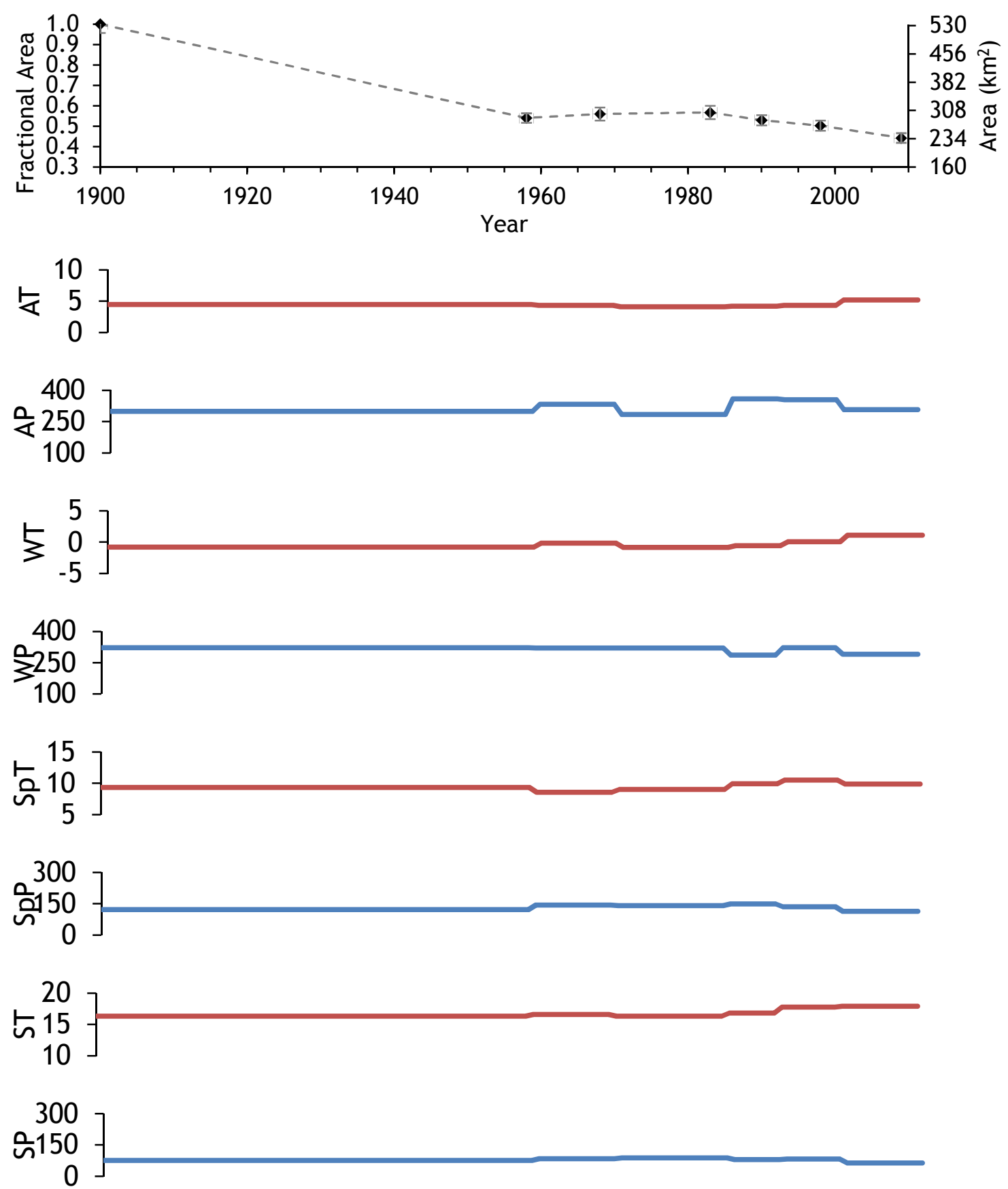

Figure 26- Annual and seasonal temperature averages over the same periods of glacier area change in the entire North Cascades region. Temperature is in degrees Celsius and precipitation is in centimeters. 
Table 24 - Precipitation (P) and Temperature $(\mathrm{T})$ for seasonal and annual averages corresponding with periods of glacier area change for the entire North Cascades. The seasonal values are as follows $\mathrm{A}=$ autumn, $\mathrm{Sp}=\mathrm{spring}$, $\mathrm{Su}=$ summer, $\mathrm{W}=$ winter.

\begin{tabular}{c|cccccccccc}
\hline \hline & AT & AP & SuT & SuP & Sp T & SpP & WT & WP & FT & F P \\
\hline $1900-1958$ & 7.5 & 203.1 & 16.3 & 75.9 & 9.3 & 121.4 & -0.8 & 322.7 & 4.5 & 300.0 \\
$1958-1968$ & 7.6 & 214.2 & 16.6 & 83.7 & 8.6 & 143.1 & -0.2 & 320.4 & 4.3 & 334.1 \\
$1968-1983$ & 7.4 & 206.8 & 16.3 & 87.3 & 9.0 & 141.4 & -0.8 & 320.3 & 4.1 & 284.2 \\
$1983-1990$ & 7.8 & 207.1 & 16.8 & 79.9 & 9.9 & 149.2 & -0.6 & 287.0 & 4.2 & 359.4 \\
$1990-1998$ & 8.4 & 216.7 & 17.8 & 82.7 & 10.5 & 136.0 & 0.0 & 322.1 & 4.3 & 354.9 \\
$1998-2009$ & 8.9 & 188.5 & 17.9 & 63.1 & 9.9 & 114.4 & 1.1 & 291.2 & 5.2 & 308.3
\end{tabular}

In addition to the temperature and precipitation comparisons, fractional area change for the entire region, Mount Baker, and South Cascade Glacier and the net mass balance measurements for South Cascade Glacier are compared to the PDO index (Figure 27). From 1900-1958 the PDO index is more positive, which is comparable to the negative fractional glacier area. From 1958-1983 the period of glacier area stability/slight advance have a negative average PDO. From 1983 to 1990 and 1990 to 1998 show a generally positive PDO associated with area loss. The South Cascade Glacier mass balance measurements have an inverse relationship with PDO, with the generally negative mass balance values associated with positive PDO values. 

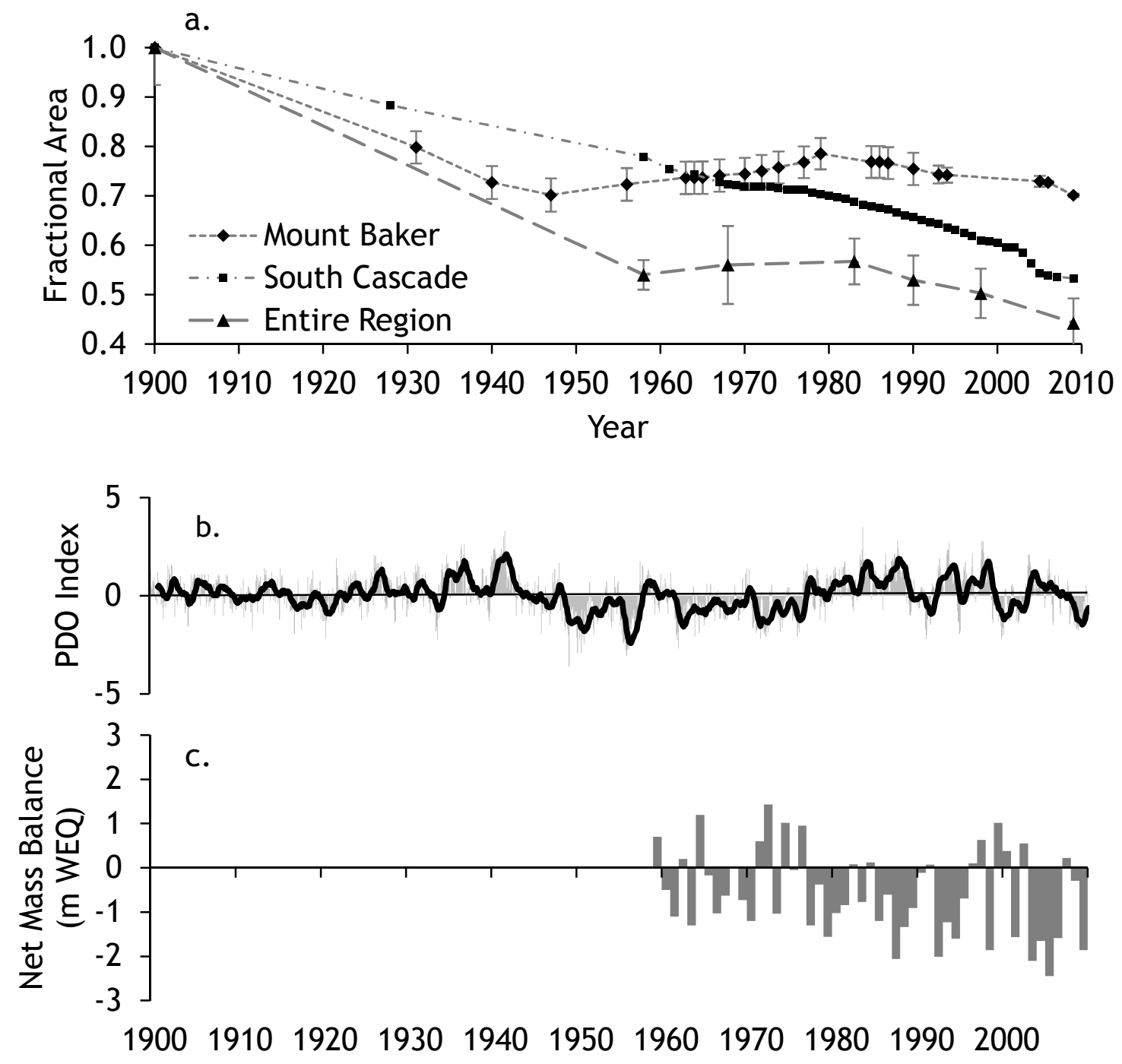

Figure 27 - North Cascades fractional area change (a), monthly PDO index values with a one year running mean (dark black line) (b), and South Cascade annual net mass balance (c) to show potential relationships over the past century.

\section{Discussion \& Conclusions}

Regional climate trends indicate that from 1900-2009 maximum air temperature has significantly increased in all seasons (except spring) and annually. No significant change in precipitation over the past century was detected. When the temperature trends are related to the time period of 
glacier area change, significant warming occurred from 1900-1958, with most of that coming in summer (ablation season) and there was a large decrease in glacier area. From 1958-1985, no temperature trend was apparent, which corresponds with the general stagnation of glaciers. From 1985-2005, there was a dramatic increase in annual temperatures and precipitation decreased, which corresponds to a retreat of glacier area. From 2005-2009 there was a small decrease in air temperature.

The correlation of warmer air temperature to more area loss is consistent over long and short time periods (1900-2009, 1983-2009 and 19982009), while correlations between precipitation and fractional area loss over shorter time periods show that precipitation can be a more important factor over short time periods (1900-1958, 1958-1990, 1968-2009). My results are consistent with a study on Mount Baker that showed accumulation season precipitation and ablation season temperatures explained variations in terminus response (Harper, 1993). My results are consistent with these results as the strongest correlations between area change and the seasonal temperature/precipitation means are in winter (precipitation) and summer (temperature). Elsewhere in the western United States, spring and summer temperature were shown to be important to glacier area change in Colorado and the Sierra Nevada (Hoffman and others, 2007, Basagic \& Fountain, 2011). In the North Cascades, summer and winter temperature warming was more 
significantly correlated to glacier area loss than spring temperature warming, which was only significant since 1958.

The results of the topographic analysis indicate that smaller glaciers at lower elevations with steeper slopes lost more area than larger, higher, less steep glaciers. When the correlations were divided into two groups based on area $\left(>0.1 \mathrm{~km}^{2}\right.$ or $<0.1 \mathrm{~km}^{2}$ ), some differences in the correlations occurred. Initial area, elevation, slope and insolation were more significant indicators of area change of larger glaciers. For the smaller glaciers, eastness, latitude, and longitude had significant correlations to area change suggesting that the geographic location of the small glaciers is more important than local topographic characteristics. No strong correlations exist between fractional area change and the various topographic variables, confirming the previous findings of Granshaw and Fountain (2006). My results are similar to other studies in the Rocky Mountains of British Columbia (BC) showing that smaller glaciers, with low slope at lower elevation had a higher absolute area change (Tennant and others, 2012). For smaller glaciers in the interior of BC, local topography of lower elevation, less steep slopes and higher insolation contributed to the glacier area change (DeBeer \& Sharp, 2009).

The multiple regression model for the North Cascades showed that the combination of topographic and climate variables only explained up to $23 \%$ of fractional area change. The significant variables for the three time periods analyzed include initial area, elevation, slope, latitude, spring and summer 
precipitation, spring, summer, and winter temperatures. The small percentage of area change that is explained by all topographic variables is consistent with the weak correlation trends above and suggests that initial area, elevation, and insolation are the main contributing factors to fractional area change. 


\section{Chapter 5 - Discussion and Conclusions}

A comparison of two glacier inventories (Post and others, 1971, Fountain and others, 2007b), one compiled by glaciologists and the other by cartographers (24K) can show overall agreement. They are most different in the number of small glaciers (less than $0.1 \mathrm{~km}^{2}$ ) with the cartographic results including all the small features. However, filtering glaciers less than $0.1 \mathrm{~km}^{2}$ from the $24 \mathrm{~K}$ inventory resulted in an underestimate of total Post and others (1971) inventory by almost half the number of glaciers, and $90 \%$ of the area. My area filtering results for the entire North Cascades are consistent with results from within the North Cascades Park Complex found by Granshaw \& Fountain (2006). Reducing the shear stress threshold to estimate the number of 'true' glaciers in the $24 \mathrm{~K}$ inventory resulted in a match of the Post and others (1971) inventory by $\sim 100 \%$ in number and $\sim 100 \%$ area. These results are similar to the Sierra Nevada (Basagic \& Fountain, 2011).

I reconciled the methods and assumptions of the Post and others (1971) inventory to the $24 \mathrm{~K}$ inventory and found better agreement the two inventories are comparable, $24 \mathrm{~K}$ identified $93 \%$ of the number of glaciers in Post and $94 \%$ of the total area. Both are within uncertainty.

Total glacier area decreased by $-56 \% \pm 3 \%$ from $1900-2009$. Most of the area loss occurred in the first half of the century from $1900-1958(-46 \% \pm 5 \%)$; from $1958-1990$ glacier area was largely unchanged with $-1 \% \pm 5 \%$, relative to 1900 area, and from 1990 to 2009 glaciers lost $-9 \% \pm 5 \%$. Small glaciers 
exhibited more variability and have also lost the most relative area. This general trend of glacier change for the region is reflected in the more detailed time series on Mount Baker and at South Cascade Glacier. The magnitude of change at South Cascade Glacier was less than Mount Baker and the entire region during the first half of the century (1900-1958). Except for a brief period of stability in the early 1970s, South Cascade Glacier has continued to decline. On Mount Baker, there was a period of growth/stability that lasted from the 1950s through the 1980s, and has been rapidly declining since then. Long term mass balance measurements for three different monitoring programs (South Cascade Glacier, NPS and NCGCP) show similar trends during their periods of record. South Cascade shows more negative mass balance than the other monitored glaciers, which suggest that it is somewhat representative of the entire region. There is overall consistency between the mass balance trends for the monitored glaciers when compared with the glacier area change for the entire North Cascades.

The results of glacier area change are similar to other glacier studies. Elsewhere in Washington State, glaciers on Mount Rainier changed by $-22 \%$ between 1913 and 1994; glaciers on Mount Adams shrank by 49\%, 1904-2006 (Sitts and others, 2010). In the Canadian Rocky Mountains glaciers shrank by 40\% between 1919 and 2009 (Tennant and others, 2012). In Oregon, the glaciers on Mount Hood shrank by 34\% between 1907 and 2004 (Jackson \& Fountain, 2007). Since the beginning of the $20^{\text {th }}$ century, the Sierra Nevada lost $55 \%$ of 
glacier area 1903 and 2004 (Basagic \& Fountain, 2011). The glaciers in Rocky Mountain National Park also lost $40 \%$ of glacier area since the turn of the century 1909-2004 (Hoffman and others, 2007). Only glaciers in Glacier National Park have lost more fractional area (65\%) than the North Cascades since the end of the LIA (Hall \& Fagre, 2003). Similar results were found in the European Alps with -36\% area change between 1850 and 2006, and in the New Zealand Alps with a -49\% glacier area loss (Hoelzle and others, 2007).

Decadal variations over the past century are similar within the North Cascades and compared to glaciers elsewhere, although variability does exist (Dyurgerov \& Meier, 2000). Within the North Cascades, there was a period of rapid retreat from 1900 through the 1940s. Between the 1950s and 1980s, glacier area was stable or advancing and since the 1980s, glaciers resumed shrinking. General trends elsewhere indicate that beginning in the 1920s glaciers were shrinking (Matthes, 1940) and that continued until the 1940s/1950s when some glaciers stabilized (Nylen, 2004, Hoffman and others, 2007, Jackson \& Fountain, 2007, Harper, 1993) and even began advancing in the 1960s (Hubley, 1956, Harper, 1993). This period of stability/advance ended in the 1980s, and glaciers started retreating again until the present time.

Climate trends in the North Cascades show that air temperature since 1900 has increased in all seasons (except spring), while precipitation does not show significant trends, consistent with Mote (2003). Warming seasonal air temperatures are correlated with glacier area shrinkage between 1900 and 
2009 , with winter and summer temperatures being more highly correlated. Over decadal periods air temperature and precipitation were correlated with glacier area change, consistent with (McCabe \& Fountain, 2013). These results are also consistent with other glacier studies that show temperature warming is better correlated with glacier area change than precipitation (Basagic, 2008, Hoffman and others, 2007).

Local topography influences glacier area change by enhancing or diminishing the effects of climate variation. More area loss was correlated with smaller glaciers on lower elevations with steeper slopes and higher mean annual insolation. For small glaciers $\left(<0.1 \mathrm{~km}^{2}\right)$, the topographic factor of facing east, and their geographic location of latitude and longitude were correlated to area loss. For small glaciers, geographic location in the region was more important that local topographic variables. These results are consistent with other glacial studies in British Columbia where glaciers at lower elevations had more glacier area loss (DeBeer \& Sharp, 2009, Tennant and others, 2012).

In conclusion, glaciers in the North Cascades have lost more than half their area since $1900(-56 \%)$. There was an initial period of glacier area decline until the 1950 s, followed by a period of stability/growth until the 1980 s, and glaciers have been rapidly declining since then. Over the past century, regional temperatures have increased, while precipitation shows no trend. The warming temperature in winter and summer caused the observed glacier area 
loss. On the decadal time scale variations in both precipitation and temperature are important. More fractional area loss was associated with smaller glaciers on lower elevations with steeper slopes and higher means annual insolation. Geographic location (facing east, latitude and longitude) was more important to fractional area loss for the smallest glaciers than their local topographic setting. 


\section{References}

EarthExplorer. US Geological Survey. http://earthexplorer.usgs.gov/.

Abermann, J., M. Kuhn, A. Lambrecht and A. Fischer 2009. Quantifying changes and trends in glacier area and volume in the Austrian Ötztal Alps (19691997-2006). Cryosphere Cryosphere, 3(2): 205-215.

Bahr, D.B., M.F. Meier and S.D. Peckham 1997. The physical basis of glacier volume-area scaling. Journal of Geophysical Research., 102(B9): 2035520362.

Basagic, H.J. 2008. Quantifying twentieth century glacier change in the Sierra Nevada, California. M.S., Portland State University. Dept. of Geography.

Basagic, H.J. and A.G. Fountain 2011. Quantifying 20th century glacier change in the Sierra Nevada, California. Arctic, Antarctic, and Alpine Research, 43(3): 317-330.

Bidlake, W.R., E.G. Josberger and M.E. Savoca 2012. Modeled and measured glacier change and related glaciological, hydrological, and meteorological conditions at South Cascade Glacier, Washington, balance and water years 2006 and 2007. 82 p. (U.S. Geological Survey Scientific Investigations Report 2010-5143).

Bidlake, W.R., E.G. Josberger and M.E. Savoca 2004. Water, ice, and meteorological measurements at South Cascade Glacier, Washington, balance year 2002. 38. (U.S. Geological Survey Scientific Investigations Report 2004-5089).

Bidlake, W.R., E.G. Josberger and M.E. Savoca 2005. Water, ice, and meteorological measurements at South Cascade Glacier, Washington, balance year 2003. 48. (U.S. Geological Survey Scientific Investigations Report 2005-5210).

Bidlake, W.R., E.G. Josberger and M.E. Savoca 2010. Modeled and measured glacier change and related glaciological, hydrological, and meteorological conditions at South Cascade Glacier, Washington, balance and water years 2006 and 2007. 82. (U.S. Geological Survey Scientific Investigations Report 2010-5143)

Bidlake, W.R., E.G. Josberger, and M.E. Savoca 2007. Water, ice, and meteorological measurements at South Cascade Glacier, Washington, 
balance years 2004 and 2005. 69. (U.S. Geological Survey Scientific Investigations Report 2007-5055).

Bitz, C.M. and D.S. Battisti 1999. Interannual to decadal variability in climate and the glacier mass balance in Washington, western Canada, and Alaska. Journal of Climate, 12(11): 3181-3196.

Chang, H., I.W. Jung, M. Steele and M. Gannett 2012. Spatial patterns of March and September streamflow trends in Pacific Northwest streams, 19582008. Geographical Analysis, 44(3): 177-201.

Chen, J. and A. Ohmura 1990. Estimation of alpine glacier water resources and their change since the 1870s. International Association of Hydrological Sciences Publication, 193 (I-Hydrology inmountainous regions: hydrologic measurements, the watercycle.): 7.

Cooley, M.J., L.R. Davis, K.A. Fishburn, H. Lestinsky and L.R. Moore 2011. US Topo Product Standard: U.S. Geological Survey Techniques and Methods 11-B2. 17.

Cooper, R.N., J.T. Houghton, J.J. McCarthy and B. Metz 2002. Review of climate change 2001: The scientific basis. Foreign Affairs, 81(1): 208208.

Cuffey, K.M. and W.S.B. Paterson 2010. The physics of glaciers. Burlington, MA, Butterworth-Heinemann/Elsevier.

DeBeer, C.M. and M.J. Sharp 2007. Recent changes in glacier area and volume within the southern Canadian Cordillera. Annals of glaciology., 46: 215221.

DeBeer, C.M. and M.J. Sharp 2009. Topographic influences on recent changes of very small glaciers in the monashee mountains, British Columbia, Canada. Journal of Glaciology, 55(192): 691-700.

Di Luzio, M., G.L. Johnson, C. Daly, J.K. Eischeid and J.G. Arnold 2008. Constructing retrospective gridded daily precipitation and temperature datasets for the conterminous United States. Journal of Applied Meteorology and Climatology, 47(2): 475-497.

Dyurgerov, M., M. Meier, and R.L. Armstrong, 2002. Glacier mass balance and regime : data of measurements and analysis. Boulder, Colo., Institute of Arctic and Alpine Research, University of Colorado. 55. 
Dyurgerov, M.B. and M.F. Meier 2000. Twentieth century climate change: evidence from small glaciers. Proceedings of the National Academy of Sciences of the United States of America, 97(4): 1406-1411.

Easterbrook, D.J. 1963. Late pleistocene glacial events and relative sea-level changes in the Northern Puget Lowland, Washington. [New York, NY], Geological Society of America.

Elsberg, D.H., W.D. Harrison, K.A. Echelmeyer and R.M. Krimmel 2001. Quantifying the effects of climate and surface change on glacier mass balance. Journal of Glaciology, 47(159): 649-658.

Fountain, A., K. Jackson, H. Basagic and D. Sitts 2007a. A century of glacier change on Mount Baker, Washington. Geological Society of America Abstracts with Programs, 67

Fountain, A.G., M. Hoffman, K. Jackson, H. Basagic, T. Nylen and D. Percy. 2007b. Digital outlines and topography of the glaciers of the American West. 23. (U.S. Geological Survey Open-File Report 2006-1340).

Fountain, A.G., R.M. Krimmel, D. Trabant and S. Geological 1997. A strategy for monitoring glaciers. 32. U.S. Geological Survey Circular 1132.

Fountain, A.G. and W.V. Tangborn 1985. The effect of glaciers on streamflow variations. Water Resources Research, 21(4): 579-586.

Ghilani, C.D. 2000. Demystifying area uncertainty: more or less. 177-182.

Graf, W.L. 1976. Cirques as glacier locations. Arctic and Alpine Research, 8(1): 79-90.

Granshaw, F.D. and A.G. Fountain 2006. Glacier change (1958-1998) in the North Cascades National Park Complex, Washington, USA. Journal of Glaciology, 52(177): 251-256.

Hall, M.H.P. and D.B. Fagre 2003. Modeled climate-induced glacier change in Glacier National Park, 1850-2100. Bioscience, 53(2): 131-140.

Harper, J.T. 1993. Glacier terminus fluctuations on Mount Baker, Washington, U.S.A., 1940-1990, and Climatic Variations. Arctic and Alpine Research, 25(4): 332-340.

Haugerud, R.A. and R.W. Tabor 2009. Geologic map of the North Cascade Range, Washington. Scientific Investigations Map 2940, U.S. Geological Survey. 
Hodge, S.M., D.C. Trabant, R.M. Krimmel, T.A. Heinrichs, R.S. March and E.G. Josberger 1998. Climate variations and changes in mass of three glaciers in Western North America. Journal of Climate, 11(9): 2161.

Hoelzle, M., T. Chinn, D. Stumm, F. Paul, M. Zemp, and W. Haeberli 2007. The application of glacier inventory data for estimating past climate change effects on mountain glaciers: A comparison between the European Alps and the Southern Alps of New Zealand. Global and Planetary Change, 56(1-2): 69-82.

Hoffman, M.J., A.G. Fountain and J.M. Achuff 2007. 20th-century variations in area of cirque glaciers and glacierets, Rocky Mountain National Park, Rocky Mountains, Colorado, USA. Annals of Glaciology., 46: 349-354.

Hubley, R.C. 1956. Glaciers of the Washington Cascade and Olympic Mountains ; their present activity and its relation to local climatic trends. Journal of Glaciology, 2(19): 669-674.

Jackson, K.M. and A.G. Fountain 2007. Spatial and morphological change on Eliot Glacier, Mount Hood, Oregon, USA. Annals of Glaciology, 46: 222226.

Johannesson, T., C. Raymond and E. Waddington 1989. Time-scale for adjustment of glaciers to changes in mass balance. Journal of Glaciology 35(121): 15.

Kaser, G., J.G. Cogley, M.B. Dyurgerov, M.F. Meier and A. Ohmura 2006. The Cryosphere - L19501 - Mass balance of glaciers and ice caps: Consensus estimates for 1961-2004 (DOI 10.1029/2006GL027511). Geophysical Research Letters., 33(19): L19501.

Kovanen, D.J. 2003. Decadal variability in climate and glacier fluctuations on Mt Baker, Washington, USA. Geografiska Annaler Series A: Physical Geography, 85(1): 43-55.

Krimmel, R.M., ed. 1989. Mass balance and volume of South Cascade Glacier, Washington 1958-1985, Dordrecht, Netherlands, Kluwer Academic Publishers.

Krimmel, R.M. 1993. Mass balance, meteorological, and runoff measurements at South Cascade Glacier, Washington, 1992 balance year. 38. (U.S. Geological Survey Open-File Report 93-640).

Krimmel, R.M. 1994. Runoff, precipitation, mass balance, and ice velocity measurements at South Cascade Glacier, Washington, 1993 balance year. 
34. (U.S. Geological Survey Water-Resources Investigations Report 944139).

Krimmel, R.M. 1995. Water, ice, and meteorological measurements at South Cascade Glacier, Washington, 1994 balance year. 41. (U.S. Geological Survey Water-Resources Investigations Report 95-4162).

Krimmel, R.M. 1996. Water, ice, and meteorological measurements at South Cascade Glacier, Washington, 1995 balance year. 37. (U.S. Geological Survey Water-Resources Investigations Report 96-4174).

Krimmel, R.M. 1997. Water, ice, and meteorological measurements at South Cascade Glacier, Washington, 1996 balance year. 34. (U.S. Geological Survey Water-Resources Investigations Report 97-4143).

Krimmel, R.M. 1998. Water, ice, and meteorological measurements at South Cascade Glacier, Washington, 1997 balance year. 30. (U.S. Geological Survey Water-Resources Investigations Report 98-4090).

Krimmel, R.M. 1999. Water, ice, and meteorological measurements at South Cascade Glacier, Washington, 1998 balance year. 36. (U.S. Geological Survey Water-Resources Investigations Report 99-4049).

Krimmel, R.M. 2000. Water, ice, and meteorological measurements at South Cascade Glacier, Washington, 1986 - 1991 balance years. 77. (U.S. Geological Survey Water-Resources Investigations Report 00-4006).

Krimmel, R.M. 2001. Water, ice, and meteorological measurements at South Cascade Glacier, Washington, 1999 balance year. 36. (U.S. Geological Survey Water-Resources Investigations Report 00-4265).

Krimmel, R.M. 2002. Water, Ice, and Meteorological Measurements at South Cascade Glacier, Washington, 2000-01 Balance Years. 63. (U.S. Geological Survey Water-Resources Investigations Report 02-4165).

Mantua, N.J., S.R. Hare, Y. Zhang, J.M. Wallace and R.C. Francis 1997. A pacific interdecadal climate oscillation with impacts on salmon production. Bulletin-American Meteorological Society, 78(6): 1069-1080.

Matthes, F., Emile 1940. Report of the committee on glaciers, 1939-40. Transactions American Geophysical Union, 1(3): 396-406.

McCabe, G.J. and M.D. Dettinger 2002. Primary modes and predictability of year-to-year snowpack variations in the Western United States from yeleconnections with Pacific Ocean climate. Journal of Hydrometeorology, 3(1): 13-25. 
McCabe, G.J. and A.G. Fountain 1995. Relations between atmospheric Circulation and Mass Balance of South Cascade Glacier, Washington, U.S.A. Arctic and Alpine Research, 27(3): 226-233.

McCabe, G.J. and A.G. Fountain 2013. Glacier variability in the conterminous United States during the twentieth century. Climatic Change, 116(3-4): 565-577.

McCabe, G.J., A.G. Fountain and M. Dyurgerov 2000. Variability in winter mass balance of northern hemisphere glaciers and relations with atmospheric circulation. Arctic, Antarctic, and Alpine research., 32(1): 64.

Meier, M.F. 1961. Distribution and variations of glaciers in the United States exclusive of Alaska. General Assembly of Helsinki, July 25-August 6, 1960: Commission of Snow and Ice, Gentbrugge, 420-429 of 588.

Meier, M.F., M.B. Dyurgerov and G.J. McCabe 2003. The health of glaciers: recent vhanges in glacier regime. Climatic Change, 59(1-2): 1-2.

Meier, M.F. and W.V. Tangborn 1965. Net budget and flow of South Cascade Glacier, Washington. Journal of Glaciology, 5(41): 19.

Mennis, J.L. and A.G. Fountain 2001. A spatio-temporal GIS database for monitoring alpine glacier change. Photogrammetric Engineering and Remote Sensing, 67(8): 967-975.

Mool, P.K, S.R. Bajracharya, and S.P. Joshi 2004 Inventory of glaciers, glacial lakes, and glacial lake outburst floods : monitoring and early warning systems in the Hindu Kush-Himalayan Region, Bhutan. Mountain research and development, 24(3): 272-274.

Moore, R.D., S.W. Fleming, B. Menounos, R. Wheate, A. Fountain, K. Stahl, K. Holm and M. Jakob 2009. Glacier change in western North America: Influences on hydrology, geomorphic hazards and water quality. Hydrological Processes, 23(25): 3650-3650.

Mote, P.W. 2003. Trends in temperature and precipitation in the Pacific Northwest during the twentieth century. Northwest Science : Official Publication of the Northwest Scientific Association., 77: 271-282.

Mote, P.W. 2005. Declining mountain snowpack in western North America. Boston, MA, American Meteorological Society.

Munn, R.E. 2002. Encyclopedia of global environmental change. Chichester; New York, Wiley. 
Nylen, T.H. 2004. Spatial and temporal variations of glaciers (1913-1994) on Mt. Rainier and the relation with climate. (M.S. Portland State University.)

O'Neal, M.A. 2005. Late Little Ice Age glacier fluctuations in the Cascade Range of Washington and northern Oregon. (Ph.D. University of Washington).

Osborn, G., B. Menounos, C. Ryane, J. Riedel, J.J. Clague, J. Koch, D. Clark, K. Scott and P.T. Davis 2012. Latest pleistocene and holocene glacier fluctuations on Mount Baker, Washington. Quaternary Science Reviews, 49: 33-51.

Paul, F. 2004. Rapid disintegration of alpine glaciers observed with satellite data. Geophysical Research Letters, 31(21).

Paul, F., R.G. Barry, J.G. Cogley, H. Frey, W. Haeberli, A. Ohmura, C.S.L. Ommanney, B. Raup, A. Rivera and M. Zemp 2009. Recommendations for the compilation of glacier inventory data from digital sources. Annals of Glaciology., (53): 119-126.

Paul, F., A. Kaab, M. Maisch, T. Kellenberger and W. Haeberli 2002. The new remote-sensing-derived Swiss glacier inventory. I. Methods. Annals of Glaciology., 34: 355-361.

Pellicciotti, F., A. Bauder and M. Parola 2010. W10522 Effect of glaciers on streamflow trends in the Swiss Alps (doi 10.1029/2009WR009039). Water Resources Research., 46(10): n.p.

Pelto, M. 1993. Current behavior of glaciers in the North Cascades and effect on regional water supplies. Washington Geology, 21(2): 7.

Pelto, M. and C. Brown 2012. Mass balance loss of Mount Baker, Washington glaciers 1990-2010. Hydrological Processes, 26(17): 2601-2607.

Pelto, M.S. 1988. The annual balance of North Cascade glaciers, Washington, USA, measured and predicted using an activity-index method. Journal of Glaciology, 34(117): 194-199.

Pelto, M.S. 2008. Glacier annual balance measurement, forecasting and climate correlations, North Cascades, Washington 1984-2006. Cryosphere, 2(1): 13-21.

Post, A., D. Richardson, W.V. Tangborn and F.L. Rosselot 1971. Inventory of glaciers in the North Cascades, Washington. (USGS Professional Paper 705-A). 
Raub, W., C.S. Brown, and A. Post 2006. Inventory of glaciers in the Sierra Nevada, California. Reston, Va., U.S. Geological Survey.

Riedel, J. and M.A. Larrabee 2011. North Cascades National Park Complex glacier mass balance monitoring annual report, Water year 2009: North Coast and Cascades Network. (Natural Resource Technical Report NPS/NCCN/NRTR-2011/483). National Park Service, Fort Collins,

Colorado.

Ruffner, J.A., 1985. Climates of the states : National Oceanic and Atmospheric Administration narrative summaries, tables, and maps for each state, with overview of state climatologist programs. Detroit, Mich., Gale Research Co.

Russell, I.C. 1897. Glaciers of North America; a reading lesson for students of geography and geology. Boston, Ginn \& Company.

Sitts, D.J., A.G. Fountain and M.J. Hoffman 2010. Twentieth century glacier change on Mount Adams, Washington, USA. Northwest Science, 84(4): 378-385.

Spicer, R.C. 1986. Glaciers in the Olympic Mountains, Washington : present distribution and recent variations. (M.S. University of Washington).

Tennant, C., B. Menounos and R. Wheate 2012. Area change of glaciers in the Canadian Rocky Mountains, 1919 to 2006. Cryosphere Discuss. Cryosphere Discussions, 6(4): 2327-2361.

USDA 2008. National Agriculture Imagery Program (NAIP) Information Sheet.

USGS 1996. Standards for Digital Orthophotos.

Yue, S., P. Pilon and G. Cavadias 2002. Power of the Mann Kendall and Spearman's rho tests for detecting monotonic trends in hydrological series. Journal of Hydrology, 259(1-4): 1-4.

Zhang, Y., J.M. Wallace and D.S. Battisti 1997. ENSO-like Interdecadal Variability: 1900-93. Journal of Climate, 10(5): 1004. 


\section{Appendix A - 24K Subset}

Each glacier from the $24 \mathrm{~K}$ subset is listed below with the following attributes, BasinID is the unique identifier, RECNO(s) are the values from the original $24 \mathrm{~K}$ dataset, year is the source year of the $24 \mathrm{~K}$ map, $\mathrm{S}_{\text {mean }}$ is the mean slope $\left({ }^{\circ}\right), Z_{\text {mean }}$ is the mean elevation $(\mathrm{m}), A_{\text {mean }}$ is the mean aspect $\left({ }^{\circ}\right), I_{\text {mean }}$ is the mean insolation $\left(\right.$ watts $\left./ \mathrm{m}^{2}\right)$, and the location of the glacier by latitude and longitude.

\begin{tabular}{|c|c|c|c|c|c|c|c|c|c|c|}
\hline BasinID & RECNO (s) & Glacier Name & Area $\left(\mathrm{km}^{2}\right)$ & Year & $\mathrm{S}_{\text {mean }}$ & $Z_{\text {mean }}$ & $A_{\text {mean }}$ & $I_{\text {mean }}$ & Latitude & Longitude \\
\hline 211102 & 2306 & & $0.035 \pm 0.005$ & 1983 & 27 & 2066 & 85 & 11858 & 48.969124 & -121.702481 \\
\hline 211103 & 2307 & & $0.015 \pm 0.003$ & 1983 & 29 & 1822 & 37 & 13437 & 48.971481 & -121.692680 \\
\hline 211104 & 2309 & & $0.530 \pm 0.019$ & 1983 & 25 & 2056 & 4 & 6896 & 48.977019 & -121.704764 \\
\hline 211201 & 2327 & & $0.048 \pm 0.006$ & 1974 & 22 & 1488 & 49 & 16850 & 48.927915 & -121.616525 \\
\hline 211202 & 2329 & & $0.012 \pm 0.003$ & 1974 & 36 & 1752 & 45 & 14517 & 48.924726 & -121.618972 \\
\hline 211203 & 2328 & & $0.081 \pm 0.007$ & 1974 & 31 & 1758 & 73 & 20991 & 48.929039 & -121.622595 \\
\hline 211204 & 2326 & & $0.036 \pm 0.005$ & 1974 & 21 & 1667 & 154 & 25398 & 48.933710 & -121.621374 \\
\hline 211205 & 2313 & & $0.015 \pm 0.003$ & 1983 & 20 & 1934 & 178 & 11922 & 48.974072 & -121.644948 \\
\hline 211206 & 2314 & & $0.081 \pm 0.007$ & 1983 & 33 & 2074 & 119 & 12214 & 48.978506 & -121.642054 \\
\hline 211207 & 2317 & & $0.021 \pm 0.004$ & 1983 & 41 & 2142 & 335 & 7125 & 48.982509 & -121.630687 \\
\hline 211208 & 2316 & & $0.034 \pm 0.005$ & 1983 & 36 & 1719 & 323 & 10304 & 48.986495 & -121.631863 \\
\hline 211209 & 2315 & & $0.173 \pm 0.011$ & 1983 & 33 & 1867 & 9 & 7929 & 48.984429 & -121.635590 \\
\hline 211210 & 2311 & & $0.839 \pm 0.024$ & 1983 & 27 & 1847 & 30 & 9535 & 48.985707 & -121.649261 \\
\hline 211211 & 2310 & & $0.232 \pm 0.012$ & 1983 & 31 & 1685 & 56 & 11173 & 48.995487 & -121.655873 \\
\hline 211301 & (Granshaw and Fountain 2006) & & $0.016 \pm 0.003$ & 1958 & 24 & 1932 & 26 & 10852 & 48.960484 & -121.512451 \\
\hline 211302 & 2337 & & $0.057 \pm 0.006$ & 1974 & 22 & 1514 & 31 & 14908 & 48.911699 & -121.553396 \\
\hline 211305 & 2330 & & $0.114 \pm 0.009$ & 1974 & 18 & 1437 & 35 & 16047 & 48.935020 & -121.564672 \\
\hline 211306 & 2331 & & $0.025 \pm 0.004$ & 1974 & 28 & 1648 & 45 & 15665 & 48.932596 & -121.570114 \\
\hline 211401 & $2198 ; 2199 ; 2200$ & & $0.105 \pm 0.008$ & 1974 & 35 & 1895 & 11 & 8196 & 48.932000 & -121.452208 \\
\hline 211402 & $2206 ; 2208$ & & $0.120 \pm 0.009$ & 1974 & 26 & 1864 & 64 & 17739 & 48.935954 & -121.460178 \\
\hline 211403 & 2213 & & $0.040 \pm 0.005$ & 1974 & 33 & 1899 & 58 & 15735 & 48.943454 & -121.465148 \\
\hline 211404 & 2214 & & $0.020 \pm 0.004$ & 1974 & 26 & 1911 & 92 & 22132 & 48.945371 & -121.466627 \\
\hline 211405 & 2220 & & $0.062 \pm 0.006$ & 1974 & 30 & 1844 & 40 & 12706 & 48.950408 & -121.467807 \\
\hline 211406 & 2221 & & $0.047 \pm 0.006$ & 1974 & 26 & 1925 & 45 & 13155 & 48.952090 & -121.472169 \\
\hline 211407 & 2251 & & $0.034 \pm 0.005$ & 1974 & 35 & 1916 & 22 & 5507 & 48.991406 & -121.462004 \\
\hline 211408 & 2260 & & $0.143 \pm 0.010$ & 1974 & 30 & 1953 & 51 & 10423 & 48.993757 & -121.468696 \\
\hline 211409 & 2263 & & $0.078 \pm 0.007$ & 1974 & 28 & 2123 & 56 & 10114 & 48.996467 & -121.473909 \\
\hline 211410 & 2263 & & $0.036 \pm 0.005$ & 1974 & 39 & 2113 & 333 & 5578 & 48.996693 & -121.477899 \\
\hline 211411 & 2254 & & $0.011 \pm 0.003$ & 1974 & 24 & 2076 & 209 & 10119 & 48.992899 & -121.474932 \\
\hline 211412 & 2256 & & $0.086 \pm 0.008$ & 1974 & 24 & 1979 & 334 & 9045 & 48.992575 & -121.484452 \\
\hline 211413 & 2257 & & $0.060 \pm 0.006$ & 1974 & 24 & 1928 & 50 & 17269 & 48.994310 & -121.489627 \\
\hline 211414 & 2227 & & $0.028 \pm 0.004$ & 1974 & 16 & 1793 & 94 & 25567 & 48.968517 & -121.493495 \\
\hline 211415 & 2056 & & $0.060 \pm 0.006$ & 1974 & 38 & 1740 & 8 & 11036 & 48.973299 & -121.502334 \\
\hline 211416 & 2324 & & $0.048 \pm 0.006$ & 1974 & 27 & 2001 & 330 & 5742 & 48.976390 & -121.522212 \\
\hline
\end{tabular}




\begin{tabular}{|c|c|c|c|c|c|c|c|c|c|c|}
\hline BasinID & RECNO (s) & Glacier Name & Area $\left(\mathrm{km}^{2}\right)$ & Year & $\mathrm{S}_{\text {mean }}$ & $\overline{Z_{\text {mean }}}$ & $A_{\text {mean }}$ & $I_{\text {mean }}$ & Latitude & Longitude \\
\hline 211501 & 2249 & & $0.109 \pm 0.009$ & 1983 & 22 & 2381 & 250 & 8227 & 48.985727 & -121.254821 \\
\hline 211502 & (Granshaw and Fountain 2006) & & $0.072 \pm 0.007$ & 1958 & 35 & 2182 & 309 & 9717 & 48.978032 & -121.259590 \\
\hline 211503 & 2237 & & $0.048 \pm 0.006$ & 1983 & 20 & 2351 & 94 & 15637 & 48.975544 & -121.253967 \\
\hline 211504 & 2231 & & $0.113 \pm 0.009$ & 1968 & 30 & 2291 & 273 & 6984 & 48.967058 & -121.247490 \\
\hline 211505 & $2226 ; 2478$ & & $0.120 \pm 0.009$ & 1983 & 31 & 2108 & 283 & 3843 & 48.962352 & -121.253541 \\
\hline 211506 & 2478 & Redoubt Glacier & $2.041 \pm 0.037$ & 1983 & 19 & 2163 & 11 & 4459 & 48.955581 & -121.272405 \\
\hline 211507 & 2228 & & $1.177 \pm 0.028$ & 1983 & 26 & 2044 & 18 & 10192 & 48.961769 & -121.290158 \\
\hline 211508 & 2233 & & $0.430 \pm 0.017$ & 1983 & 32 & 2078 & 52 & 17356 & 48.964947 & -121.302623 \\
\hline 211509 & 2232 & & $0.181 \pm 0.011$ & 1983 & 32 & 2106 & 2 & 8227 & 48.966308 & -121.314221 \\
\hline 211510 & 2236 & & $0.176 \pm 0.011$ & 1983 & 29 & 1910 & 32 & 15254 & 48.970283 & -121.323064 \\
\hline 211601 & 2278 & & $0.038 \pm 0.005$ & 1983 & 28 & 2335 & 282 & 14847 & 48.953797 & -121.305983 \\
\hline 211602 & (Granshaw and Fountain 2006) & & $0.058 \pm 0.006$ & 1958 & 27 & 2282 & 221 & 15643 & 48.951905 & -121.299575 \\
\hline 211603 & 2279 & & $0.196 \pm 0.011$ & 1983 & 32 & 1829 & 345 & 10819 & 48.930428 & -121.323664 \\
\hline 211604 & 2203 & & $0.034 \pm 0.005$ & 1983 & 35 & 1821 & 36 & 15228 & 48.932148 & -121.337592 \\
\hline 211701 & 2177 & & $0.046 \pm 0.006$ & 1983 & 29 & 1946 & 39 & 15181 & 48.890007 & -121.362126 \\
\hline 211702 & 2178 & & $0.040 \pm 0.005$ & 1983 & 33 & 1905 & 4 & 9067 & 48.891914 & -121.365115 \\
\hline 211801 & 2149 & & $0.260 \pm 0.013$ & 1974 & 34 & 1862 & 339 & 11365 & 48.859968 & -121.379156 \\
\hline 211802 & 2144 & & $0.179 \pm 0.011$ & 1974 & 29 & 1717 & 349 & 9000 & 48.859821 & -121.388140 \\
\hline 211803 & $2135 ; 2151$ & & $0.082 \pm 0.007$ & 1974 & 29 & 1683 & 7 & 10668 & 48.860202 & -121.396019 \\
\hline 211804 & 2151 & & $0.509 \pm 0.018$ & 1974 & 26 & 1681 & 12 & 11378 & 48.861065 & -121.410411 \\
\hline 211901 & 2145 & & $0.159 \pm 0.010$ & 1974 & 27 & 1922 & 69 & 13842 & 48.858121 & -121.459298 \\
\hline 211902 & 2145 & & $0.097 \pm 0.008$ & 1974 & 33 & 1805 & 50 & 14617 & 48.861531 & -121.458592 \\
\hline 211905 & 2437 & & $0.314 \pm 0.015$ & 1974 & 26 & 1818 & 29 & 8579 & 48.864575 & -121.522379 \\
\hline 212101 & 2319 & & $0.172 \pm 0.011$ & 1983 & 24 & 1795 & 13 & 9247 & 48.928884 & -121.634077 \\
\hline 212102 & 2304 & & $0.016 \pm 0.003$ & 1983 & 21 & 1995 & 282 & 15804 & 48.926352 & -121.639984 \\
\hline 212201 & 2437 & & $0.538 \pm 0.019$ & 1974 & 27 & 1950 & 348 & 5258 & 48.863889 & -121.535816 \\
\hline 212202 & 2422 & & $0.049 \pm 0.006$ & 1974 & 18 & 1602 & 50 & 14605 & 48.870145 & -121.545319 \\
\hline 212203 & 2418 & & $0.043 \pm 0.005$ & 1974 & 28 & 1906 & 44 & 10369 & 48.871886 & -121.554295 \\
\hline 212204 & 2346 & & $0.037 \pm 0.005$ & 1974 & 29 & 1930 & 54 & 14877 & 48.876617 & -121.564129 \\
\hline 212205 & 2344 & & $0.093 \pm 0.008$ & 1974 & 17 & 1592 & 19 & 15072 & 48.880020 & -121.570921 \\
\hline 212206 & 2343 & & $0.062 \pm 0.006$ & 1974 & 32 & 1759 & 5 & 11107 & 48.886610 & -121.576098 \\
\hline 212207 & 2342 & & $0.076 \pm 0.007$ & 1974 & 28 & 1850 & 13 & 10562 & 48.886140 & -121.581746 \\
\hline 212208 & 2341 & & $0.099 \pm 0.008$ & 1974 & 29 & 1977 & 40 & 11724 & 48.886002 & -121.586531 \\
\hline 212209 & 2341 & & $0.136 \pm 0.010$ & 1974 & 27 & 1799 & 59 & 18189 & 48.890510 & -121.586317 \\
\hline 212210 & 2338 & & $0.039 \pm 0.005$ & 1974 & 30 & 1778 & 39 & 14498 & 48.894020 & -121.588811 \\
\hline 212211 & 2339 & & $0.041 \pm 0.005$ & 1974 & 38 & 1781 & 45 & 16156 & 48.897143 & -121.592780 \\
\hline 212212 & 2340 & & $0.233 \pm 0.012$ & 1974 & 27 & 1832 & 324 & 12763 & 48.895374 & -121.598697 \\
\hline 212301 & 2429 & & $0.034 \pm 0.005$ & 1974 & 24 & 2021 & 252 & 7639 & 48.857978 & -121.535863 \\
\hline 212302 & 2444 & & $0.574 \pm 0.020$ & 1974 & 25 & 1861 & 301 & 3641 & 48.839667 & -121.533916 \\
\hline 212303 & 10478 & East Nooksack Glacier & $0.577 \pm 0.020$ & 1974 & 30 & 1731 & 298 & 5457 & 48.828457 & -121.540771 \\
\hline 212304 & 10478 & East Nooksack Glacier & $2.244 \pm 0.039$ & 1974 & 28 & 1822 & 48 & 15624 & 48.828656 & -121.571158 \\
\hline 212305 & 2408 & West Nooksack Glacier & $0.166 \pm 0.011$ & 1974 & 36 & 1806 & 73 & 16356 & 48.842016 & -121.574920 \\
\hline 212306 & 2485 & Price Glacier & $1.615 \pm 0.033$ & 1974 & 31 & 1750 & 353 & 11114 & 48.843764 & -121.590289 \\
\hline
\end{tabular}




\begin{tabular}{|c|c|c|c|c|c|c|c|c|c|c|}
\hline BasinlD & RECNO (s) & Glacier Name & Area $\left(\mathrm{km}^{2}\right)$ & Year & $\mathrm{S}_{\text {mean }}$ & $Z_{\text {mean }}$ & $A_{\text {mean }}$ & $I_{\text {mean }}$ & Latitude & Longitude \\
\hline 212307 & 2419 & & $0.106 \pm 0.008$ & 1974 & 42 & 1985 & 7 & 8214 & 48.842360 & -121.599836 \\
\hline 212401 & $2421 ; 2488$ & Hanging Glacier & $0.582 \pm 0.020$ & 1974 & 33 & 2132 & 306 & 10611 & 48.837795 & -121.606434 \\
\hline 212402 & $1860 ; 2421$ & & $0.807 \pm 0.023$ & 1974 & 28 & 1689 & 344 & 6742 & 48.837576 & -121.620309 \\
\hline 212403 & 1861 & & $0.158 \pm 0.010$ & 1974 & 31 & 1717 & 16 & 10219 & 48.836595 & -121.634531 \\
\hline 212404 & 2405 & & $0.082 \pm 0.007$ & 1974 & 27 & 1598 & 1 & 6292 & 48.838679 & -121.642369 \\
\hline 212501 & 2383 & Table Mountain Glacier & $0.159 \pm 0.010$ & 1974 & 21 & 1655 & 23 & 4528 & 48.849800 & -121.707247 \\
\hline 212601 & 1856 & & $0.157 \pm 0.010$ & 1974 & 25 & 1674 & 335 & 3698 & 48.826746 & -121.732883 \\
\hline 212602 & 1840 & & $0.560 \pm 0.019$ & 1974 & 23 & 1799 & 16 & 5902 & 48.823701 & -121.745752 \\
\hline 212603 & 10477 & Sholes Glacier & $1.189 \pm 0.028$ & 1975 & 19 & 1844 & 8 & 4574 & 48.813830 & -121.768156 \\
\hline 212604 & 10476 & Mazama Glacier & $5.397 \pm 0.060$ & 1975 & 22 & 2025 & 15 & 5542 & 48.801385 & -121.802008 \\
\hline 212605 & 10523 & & $0.309 \pm 0.014$ & 1975 & 23 & 2083 & 92 & 9454 & 48.808799 & -121.818827 \\
\hline 212606 & 1829 & & $0.328 \pm 0.015$ & 1975 & 17 & 2032 & 97 & 4313 & 48.814734 & -121.813421 \\
\hline 212607 & 1838 & & $0.097 \pm 0.008$ & 1975 & 25 & 1943 & 48 & 9282 & 48.820868 & -121.808640 \\
\hline 212608 & 1835 & Hadley Glacier & $0.727 \pm 0.022$ & 1975 & 26 & 2008 & 354 & 5234 & 48.818759 & -121.820527 \\
\hline 212609 & 1835 & Hadley Glacier & $0.232 \pm 0.012$ & 1975 & 30 & 1981 & 38 & 10628 & 48.820985 & -121.834561 \\
\hline 212610 & 1835 & Hadley Glacier & $0.128 \pm 0.009$ & 1975 & 20 & 2037 & 24 & 5856 & 48.826396 & -121.843429 \\
\hline 212701 & 10523 & & $0.228 \pm 0.012$ & 1975 & 25 & 2178 & 323 & 8694 & 48.807257 & -121.826374 \\
\hline 212702 & 2496 & Roosevelt Glacier & $3.571 \pm 0.049$ & 1975 & 22 & 2247 & 313 & 10502 & 48.792256 & -121.830675 \\
\hline 212703 & 2497 & Coleman Glacier & $5.088 \pm 0.058$ & 1975 & 23 & 2046 & 321 & 8874 & 48.784478 & -121.844653 \\
\hline 212704 & 2497 & & $3.817 \pm 0.051$ & 1975 & 23 & 2269 & 341 & 6616 & 48.783468 & -121.866946 \\
\hline 213101 & 2498 & Thunder Glacier & $0.939 \pm 0.025$ & 1975 & 27 & 2142 & 290 & 10175 & 48.773466 & -121.862761 \\
\hline 213102 & 1806 & & $0.221 \pm 0.012$ & 1975 & 21 & 1952 & 296 & 14816 & 48.758314 & -121.870307 \\
\hline 213103 & 1809 & & $0.056 \pm 0.006$ & 1975 & 38 & 2171 & 262 & 18005 & 48.764816 & -121.865111 \\
\hline 213104 & 1807 & & $0.124 \pm 0.009$ & 1975 & 38 & 2242 & 261 & 16304 & 48.759685 & -121.862567 \\
\hline 213105 & 2499 & Deming Glacier & $4.996 \pm 0.058$ & 1975 & 22 & 2271 & 218 & 17417 & 48.760892 & -121.841482 \\
\hline 213201 & 1610 & & $0.709 \pm 0.022$ & 1974 & 27 & 1687 & 20 & 10540 & 48.696866 & -121.973908 \\
\hline 213202 & 1614 & & $0.970 \pm 0.025$ & 1974 & 20 & 1813 & 30 & 7283 & 48.708820 & -121.982706 \\
\hline 221101 & 2500 & Easton Glacier & $2.888 \pm 0.044$ & 1975 & 19 & 2174 & 200 & 28079 & 48.749559 & -121.829955 \\
\hline 221102 & 2503 & Talum Glaciers & $2.155 \pm 0.038$ & 1975 & 26 & 2254 & 131 & 21429 & 48.756712 & -121.803199 \\
\hline 221103 & 2502 & Boulder Glacier & $3.851 \pm 0.051$ & 1975 & 25 & 2262 & 97 & 13710 & 48.767183 & -121.793943 \\
\hline 221104 & 2495 & Park Glacier & $3.149 \pm 0.046$ & 1975 & 22 & 2081 & 97 & 10535 & 48.784854 & -121.787668 \\
\hline 221105 & 1802 & & $0.196 \pm 0.011$ & 1975 & 25 & 1567 & 59 & 16980 & 48.784339 & -121.750665 \\
\hline 221106 & 1850 & & $0.205 \pm 0.012$ & 1975 & 30 & 1774 & 47 & 13108 & 48.787216 & -121.758090 \\
\hline 221107 & 1824 & & $0.304 \pm 0.014$ & 1975 & 23 & 1529 & 39 & 14993 & 48.792648 & -121.762625 \\
\hline 221108 & 2494 & Rainbow Glacier & $1.784 \pm 0.035$ & 1975 & 21 & 1816 & 65 & 10151 & 48.796699 & -121.779496 \\
\hline 221109 & 2494 & Rainbow Glacier & $0.449 \pm 0.017$ & 1975 & 23 & 1778 & 142 & 2851 & 48.803991 & -121.774117 \\
\hline 221110 & 2494 & Rainbow Glacier & $0.133 \pm 0.009$ & 1975 & 24 & 1876 & 143 & 7425 & 48.807251 & -121.771959 \\
\hline 221201 & 1851 & & $0.077 \pm 0.007$ & 1974 & 12 & 1665 & 280 & 3012 & 48.808421 & -121.733469 \\
\hline 221202 & 1874 & & $0.234 \pm 0.013$ & 1974 & 19 & 1637 & 31 & 4427 & 48.814763 & -121.734507 \\
\hline 221203 & $1862 ; 1863 ; 1864$ & & $0.188 \pm 0.011$ & 1974 & 23 & 1641 & 335 & 3395 & 48.817605 & -121.663308 \\
\hline 221204 & $1866 ; 2489$ & Lower Curtis Glacier & $0.873 \pm 0.024$ & 1974 & 24 & 1883 & 274 & 10780 & 48.827313 & -121.618996 \\
\hline 221205 & 2487 & Sulphide Glacier & $0.277 \pm 0.014$ & 1974 & 33 & 1999 & 273 & 11987 & 48.817935 & -121.620280 \\
\hline 221206 & 2487 & Sulphide Glacier & $0.119 \pm 0.009$ & 1974 & 34 & 2231 & 253 & 19624 & 48.814446 & -121.616120 \\
\hline
\end{tabular}




\begin{tabular}{|c|c|c|c|c|c|c|c|c|c|c|}
\hline BasinID & RECNO (s) & Glacier Name & Area $\left(\mathrm{km}^{2}\right)$ & Year & $\mathrm{S}_{\text {mean }}$ & $\overline{Z_{\text {mean }}}$ & $A_{\text {mean }}$ & $I_{\text {mean }}$ & Latitude & Longitude \\
\hline 221301 & $1901 ; 2487$ & Sulphide Glacier & $3.667 \pm 0.050$ & 1974 & 21 & 2108 & 136 & 15331 & 48.814109 & -121.604566 \\
\hline 221302 & 2486 & Crystal Glacier & $2.385 \pm 0.040$ & 1974 & 24 & 2233 & 166 & 20627 & 48.823502 & -121.589532 \\
\hline 221303 & 1882; 1912; 1913; 1914 & & $0.257 \pm 0.013$ & 1974 & 30 & 1793 & 129 & 7488 & 48.813882 & -121.570859 \\
\hline 221304 & 1885 & & $0.284 \pm 0.014$ & 1974 & 33 & 2010 & 174 & 19517 & 48.818713 & -121.556972 \\
\hline 221401 & 10479 & & $0.276 \pm 0.014$ & 1974 & 31 & 1696 & 96 & 24769 & 48.820456 & -121.541366 \\
\hline 221402 & 1897 & & $0.113 \pm 0.009$ & 1974 & 32 & 1976 & 214 & 10706 & 48.833593 & -121.527805 \\
\hline 221403 & 2439; 2444; 2445 & & $0.272 \pm 0.014$ & 1974 & 28 & 1784 & 32 & 13112 & 48.841642 & -121.526211 \\
\hline 221404 & $2434 ; 2435$ & & $0.020 \pm 0.004$ & 1974 & 20 & 1763 & 87 & 1113 & 48.848791 & -121.533099 \\
\hline 221405 & 2437 & & $0.230 \pm 0.012$ & 1974 & 26 & 1992 & 85 & 11740 & 48.860259 & -121.528364 \\
\hline 221406 & 2423 & & $0.044 \pm 0.005$ & 1974 & 18 & 1761 & 81 & 877 & 48.859262 & -121.509663 \\
\hline 221501 & $2109 ; 2145$ & & $0.423 \pm 0.017$ & 1974 & 30 & 1541 & 78 & 21840 & 48.845963 & -121.455179 \\
\hline 221502 & 2145 & & $0.083 \pm 0.007$ & 1974 & 36 & 1835 & 106 & 13793 & 48.854989 & -121.457676 \\
\hline 221503 & 2095 & & $0.178 \pm 0.011$ & 1983 & 40 & 1759 & 294 & 13981 & 48.836938 & -121.368287 \\
\hline 221504 & 2090 & & $0.116 \pm 0.009$ & 1974 & 25 & 1365 & 306 & 17534 & 48.837112 & -121.377206 \\
\hline 221601 & 10471 & & $0.088 \pm 0.008$ & 1983 & 28 & 2201 & 218 & 20074 & 48.834874 & -121.359844 \\
\hline 221602 & 10471 & & $0.113 \pm 0.009$ & 1983 & 25 & 2246 & 224 & 20082 & 48.834441 & -121.355967 \\
\hline 221603 & 2089 & & $0.798 \pm 0.023$ & 1983 & 26 & 2144 & 233 & 11748 & 48.831234 & -121.348519 \\
\hline 221604 & 1742 & & $0.160 \pm 0.010$ & 1983 & 34 & 2001 & 265 & 10154 & 48.820539 & -121.346301 \\
\hline 221605 & 1714 & & $0.200 \pm 0.012$ & 1983 & 33 & 1682 & 328 & 14211 & 48.802031 & -121.353753 \\
\hline 221606 & 1707 & & $0.697 \pm 0.022$ & 1983 & 27 & 1862 & 45 & 13368 & 48.791765 & -121.381235 \\
\hline 221701 & 1706 & & $0.259 \pm 0.013$ & 1974 & 29 & 1993 & 323 & 5259 & 48.793127 & -121.395109 \\
\hline 221702 & 1765 & & $0.096 \pm 0.008$ & 1974 & 25 & 1644 & 352 & 5522 & 48.750295 & -121.387911 \\
\hline 221703 & 1635 & & $0.114 \pm 0.009$ & 1974 & 16 & 1507 & 19 & 8977 & 48.752239 & -121.397030 \\
\hline 221704 & 1603 & & $0.438 \pm 0.017$ & 1985 & 30 & 1708 & 348 & 8850 & 48.748414 & -121.418651 \\
\hline 221705 & 2001 & & $0.103 \pm 0.008$ & 1985 & 30 & 1824 & 348 & 7915 & 48.738462 & -121.432372 \\
\hline 221706 & 1988 & & $0.153 \pm 0.010$ & 1985 & 23 & 1566 & 319 & 10308 & 48.742418 & -121.435292 \\
\hline 221707 & 2000 & & $0.085 \pm 0.008$ & 1985 & 15 & 1388 & 333 & 10606 & 48.733354 & -121.446935 \\
\hline 221708 & 1998 & & $0.100 \pm 0.008$ & 1985 & 36 & 1766 & 59 & 17154 & 48.736094 & -121.463850 \\
\hline 221709 & 1997 & & $0.140 \pm 0.010$ & 1985 & 27 & 1594 & 14 & 13106 & 48.738846 & -121.469023 \\
\hline 221710 & 1994 & & $0.071 \pm 0.007$ & 1985 & 30 & 1992 & 39 & 10968 & 48.738523 & -121.480942 \\
\hline 221711 & 1996 & & $0.131 \pm 0.009$ & 1985 & 21 & 1438 & 64 & 20006 & 48.743406 & -121.470331 \\
\hline 221712 & 1999 & & $0.041 \pm 0.005$ & 1985 & 34 & 1940 & 82 & 16541 & 48.745599 & -121.478697 \\
\hline 221713 & 1767 & & $0.066 \pm 0.007$ & 1985 & 25 & 1742 & 132 & 1401 & 48.749647 & -121.472587 \\
\hline 221714 & 1646 & & $0.473 \pm 0.018$ & 1974 & 25 & 1957 & 96 & 11183 & 48.756990 & -121.473514 \\
\hline 221801 & 1665 & & $0.250 \pm 0.013$ & 1974 & 21 & 1833 & 347 & 4202 & 48.769948 & -121.456870 \\
\hline 221802 & 1763 & & $0.083 \pm 0.007$ & 1974 & 33 & 1922 & 352 & 7880 & 48.762999 & -121.469610 \\
\hline 221803 & $1647 ; 1648$ & & $0.094 \pm 0.008$ & 1974 & 35 & 1784 & 318 & 10379 & 48.762439 & -121.475787 \\
\hline 221804 & 1646 & & $0.276 \pm 0.014$ & 1974 & 33 & 1905 & 352 & 9963 & 48.759151 & -121.480716 \\
\hline 221805 & 1646 & & $0.241 \pm 0.013$ & 1974 & 33 & 1899 & 359 & 9214 & 48.758974 & -121.488733 \\
\hline 221806 & (Granshaw and Fountain 2006) & & $0.140 \pm 0.010$ & 1958 & 25 & 1789 & 345 & 9491 & 48.744321 & -121.487520 \\
\hline 221807 & 1995 & & $0.045 \pm 0.005$ & 1985 & 28 & 2013 & 339 & 5801 & 48.741383 & -121.484536 \\
\hline 221808 & 1993 & & $0.128 \pm 0.009$ & 1985 & 16 & 1950 & 315 & 5988 & 48.737087 & -121.486837 \\
\hline 221809 & 1986 & & $1.123 \pm 0.027$ & 1985 & 21 & 1893 & 323 & 5186 & 48.727396 & -121.497908 \\
\hline
\end{tabular}




\begin{tabular}{|c|c|c|c|c|c|c|c|c|c|c|}
\hline BasinID & RECNO (s) & Glacier Name & Area $\left(\mathrm{km}^{2}\right)$ & Year & $\mathrm{S}_{\text {mean }}$ & $Z_{\text {mean }}$ & $A_{\text {mean }}$ & $I_{\text {mean }}$ & Latitude & Longitude \\
\hline 221901 & 1969 & & $0.779 \pm 0.023$ & 1974 & 16 & 1857 & 350 & 3485 & 48.672131 & -121.527652 \\
\hline 221902 & 1981 & & $0.111 \pm 0.009$ & 1974 & 23 & 2076 & 283 & 14759 & 48.665233 & -121.520572 \\
\hline 221903 & 1970; 1978 & & $0.144 \pm 0.010$ & 1974 & 23 & 1598 & 31 & 14187 & 48.654581 & -121.562254 \\
\hline 221904 & 1979 & & $0.269 \pm 0.013$ & 1974 & 24 & 1735 & 20 & 7042 & 48.657771 & -121.575390 \\
\hline 222101 & 1981 & & $1.294 \pm 0.029$ & 1974 & 16 & 1935 & 122 & 9087 & 48.662733 & -121.509164 \\
\hline 222102 & 1985 & & $0.236 \pm 0.013$ & 1985 & 13 & 1633 & 235 & 3794 & 48.659262 & -121.497011 \\
\hline 222103 & 2014 & & $0.094 \pm 0.008$ & 1985 & 17 & 1691 & 305 & 5238 & 48.647053 & -121.490931 \\
\hline 222201 & 2013 & & $0.043 \pm 0.005$ & 1985 & 34 & 1794 & 77 & 21276 & 48.646897 & -121.481466 \\
\hline 222202 & 2012 & & $0.185 \pm 0.011$ & 1985 & 33 & 1771 & 52 & 14648 & 48.651727 & -121.485291 \\
\hline 222203 & 1981 & & $0.103 \pm 0.008$ & 1958 & 28 & 1717 & 89 & 10262 & 48.660723 & -121.490619 \\
\hline 222204 & 2015 & & $0.071 \pm 0.007$ & 1985 & 21 & 1820 & 61 & 6049 & 48.664768 & -121.491510 \\
\hline 222205 & 1969 & & $0.890 \pm 0.024$ & 1974 & 15 & 1822 & 0 & 1671 & 48.673399 & -121.496716 \\
\hline 222206 & 1969 & & $1.149 \pm 0.028$ & 1974 & 21 & 1877 & 17 & 6023 & 48.671249 & -121.510516 \\
\hline 222207 & 1968 & & $0.112 \pm 0.009$ & 1974 & 23 & 1864 & 19 & 3792 & 48.677441 & -121.518532 \\
\hline 222208 & 1992 & & $0.352 \pm 0.015$ & 1985 & 26 & 1868 & 73 & 15413 & 48.732275 & -121.482850 \\
\hline 222209 & 2003 & & $0.039 \pm 0.005$ & 1985 & 22 & 1875 & 129 & 7141 & 48.741737 & -121.425237 \\
\hline 222210 & (Granshaw and Fountain 2006) & & $0.082 \pm 0.007$ & 1958 & 37 & 1665 & 278 & 3294 & 48.740799 & -121.384011 \\
\hline 222301 & $2030 ; 2031$ & & $0.536 \pm 0.019$ & 1983 & 27 & 1686 & 82 & 20787 & 48.703446 & -121.348349 \\
\hline 222302 & $2021 ; 2022$ & & $0.210 \pm 0.012$ & 1983 & 28 & 1522 & 0 & 11499 & 48.712177 & -121.355895 \\
\hline 222303 & 2024 & & $0.125 \pm 0.009$ & 1983 & 27 & 1572 & 6 & 13807 & 48.711984 & -121.367695 \\
\hline 222304 & 2029 & & $0.027 \pm 0.004$ & 1983 & 39 & 1376 & 53 & 17262 & 48.737327 & -121.361870 \\
\hline 222305 & 2006 & & $0.205 \pm 0.012$ & 1983 & 33 & 1872 & 95 & 24124 & 48.739575 & -121.373021 \\
\hline 222306 & $2006 ; 2028$ & & $0.211 \pm 0.012$ & 1983 & 33 & 1800 & 37 & 14001 & 48.745523 & -121.373690 \\
\hline 222307 & $2026 ; 2027$ & & $0.084 \pm 0.007$ & 1983 & 32 & 1469 & 34 & 14587 & 48.746620 & -121.365353 \\
\hline 222308 & 1766 & & $0.159 \pm 0.010$ & 1974 & 24 & 1549 & 18 & 12515 & 48.750345 & -121.380711 \\
\hline 222309 & 1707 & & $0.287 \pm 0.014$ & 1974 & 26 & 1907 & 45 & 13481 & 48.784916 & -121.374463 \\
\hline 222310 & 1704 & & $0.054 \pm 0.006$ & 1983 & 34 & 1658 & 199 & 347 & 48.793128 & -121.357438 \\
\hline 222311 & 1709 & & $0.150 \pm 0.010$ & 1983 & 36 & 1708 & 84 & 23106 & 48.797208 & -121.346015 \\
\hline 222312 & 1723 & & $0.103 \pm 0.008$ & 1983 & 39 & 1829 & 183 & 4942 & 48.805808 & -121.322835 \\
\hline 222313 & 1670 & & $0.235 \pm 0.013$ & 1983 & 36 & 2121 & 227 & 16973 & 48.771949 & -121.302288 \\
\hline 222314 & 1664 & Terror Glacier & $0.728 \pm 0.022$ & 1983 & 28 & 2064 & 146 & 9822 & 48.766843 & -121.289335 \\
\hline 222315 & 1669 & & $0.190 \pm 0.011$ & 1983 & 29 & 2077 & 165 & 13353 & 48.770712 & -121.275235 \\
\hline 222316 & 1661 & & $0.215 \pm 0.012$ & 1983 & 21 & 1751 & 243 & 2677 & 48.764765 & -121.275282 \\
\hline 222401 & 1630 & & $0.355 \pm 0.015$ & 1958 & 31 & 1357 & 40 & 14894 & 48.733232 & -121.196974 \\
\hline 222402 & 1629 & & $0.186 \pm 0.011$ & 1958 & 29 & 1875 & 355 & 9722 & 48.732663 & -121.208726 \\
\hline 222403 & $1759 ; 2032 ; 2490$ & & $0.167 \pm 0.011$ & 1958 & 32 & 1578 & 59 & 18409 & 48.733240 & -121.253341 \\
\hline 222404 & 1771 & & $0.169 \pm 0.011$ & 1983 & 30 & 1955 & 128 & 4598 & 48.752438 & -121.251903 \\
\hline 222405 & 1649 & & $0.126 \pm 0.009$ & 1968 & 32 & 1490 & 30 & 13387 & 48.759205 & -121.248909 \\
\hline 222406 & $1640 ; 1651$ & & $0.097 \pm 0.008$ & 1983 & 33 & 1587 & 53 & 17411 & 48.760354 & -121.253880 \\
\hline 222407 & 1644 & & $0.037 \pm 0.005$ & 1983 & 40 & 1937 & 7 & 12071 & 48.758679 & -121.260788 \\
\hline 222408 & 1675 & & $0.286 \pm 0.014$ & 1983 & 34 & 1798 & 117 & 18121 & 48.772042 & -121.267093 \\
\hline 222501 & 2491 & Neve Glacier & $0.462 \pm 0.018$ & 1958 & 25 & 1901 & 316 & 8067 & 48.654405 & -121.152469 \\
\hline 222502 & 1619 & & $0.181 \pm 0.011$ & 1958 & 29 & 1989 & 346 & 8281 & 48.646473 & -121.167458 \\
\hline
\end{tabular}




\begin{tabular}{|c|c|c|c|c|c|c|c|c|c|c|}
\hline BasinID & RECNO (s) & Glacier Name & Area $\left(\mathrm{km}^{2}\right)$ & Year & $\mathrm{S}_{\text {mean }}$ & $\overline{Z_{\text {mean }}}$ & $A_{\text {mean }}$ & $I_{\text {mean }}$ & Latitude & Longitude \\
\hline 222601 & 3131 & & $0.077 \pm 0.007$ & 1958 & 23 & 2028 & 305 & 7079 & 48.578134 & -121.187771 \\
\hline 222602 & 3130 & & $0.091 \pm 0.008$ & 1958 & 28 & 1691 & 13 & 11405 & 48.568213 & -121.222812 \\
\hline 222603 & 3343 & & $0.355 \pm 0.015$ & 1983 & 33 & 1952 & 84 & 12053 & 48.583765 & -121.268427 \\
\hline 222701 & 3355 & & $0.166 \pm 0.011$ & 1983 & 27 & 1936 & 314 & 9629 & 48.576613 & -121.273562 \\
\hline 223101 & $1678 ; 1682$ & & $0.533 \pm 0.019$ & 1983 & 38 & 1752 & 355 & 11569 & 48.776887 & -121.282375 \\
\hline 223102 & $1690 ; 1692 ; 1969 ; 1770$ & & $0.945 \pm 0.025$ & 1983 & 35 & 1776 & 29 & 15967 & 48.781100 & -121.304836 \\
\hline 223103 & 1710 & & $0.142 \pm 0.010$ & 1983 & 34 & 2146 & 131 & 7663 & 48.800503 & -121.303600 \\
\hline 223104 & 1715 & & $0.105 \pm 0.008$ & 1983 & 43 & 1821 & 72 & 21065 & 48.802989 & -121.297904 \\
\hline 223105 & 2481 & & $0.629 \pm 0.021$ & 1983 & 31 & 2197 & 112 & 17343 & 48.808097 & -121.304919 \\
\hline 223201 & $2085 ; 2088 ; 2094$ & & $0.122 \pm 0.009$ & 1983 & 40 & 1883 & 333 & 13032 & 48.834756 & -121.274462 \\
\hline 223202 & $1740 ; 1743$ & & $0.358 \pm 0.015$ & 1983 & 30 & 1845 & 323 & 12419 & 48.819133 & -121.289689 \\
\hline 223203 & 2480 & & $0.393 \pm 0.016$ & 1983 & 30 & 1930 & 2 & 12092 & 48.816896 & -121.301706 \\
\hline 223204 & $2479 ; 2480$ & & $0.375 \pm 0.016$ & 1983 & 42 & 2070 & 355 & 11204 & 48.814956 & -121.311906 \\
\hline 223205 & $1744 ; 1748 ; 10470$ & & $1.775 \pm 0.034$ & 1983 & 29 & 1732 & 55 & 17682 & 48.824534 & -121.327642 \\
\hline 223206 & 10470 & & $0.307 \pm 0.014$ & 1983 & 30 & 2157 & 118 & 5779 & 48.839440 & -121.333669 \\
\hline 223207 & (Granshaw and Fountain 2006) & Challenger Glacier & $0.986 \pm 0.026$ & 1983 & 16 & 2016 & 81 & 3418 & 48.844927 & -121.352685 \\
\hline 223301 & 2146 & & $1.008 \pm 0.026$ & 1983 & 23 & 2042 & 356 & 5551 & 48.857812 & -121.320734 \\
\hline 223302 & 10469 & Challenger Glacier & $3.397 \pm 0.048$ & 1975 & 23 & 2023 & 354 & 5310 & 48.844927 & -121.352685 \\
\hline 223303 & (Granshaw and Fountain 2006) & & $0.350 \pm 0.015$ & 1975 & 26 & 2105 & 129 & 6442 & 48.844927 & -121.352685 \\
\hline 223304 & 2156 & Whatcom Glacier & $0.371 \pm 0.016$ & 1983 & 32 & 1766 & 56 & 17978 & 48.861821 & -121.367480 \\
\hline 223305 & 2287 & & $0.050 \pm 0.006$ & 1983 & 22 & 2011 & 189 & 4988 & 48.923203 & -121.302137 \\
\hline 223401 & 2283 & & $0.124 \pm 0.009$ & 1983 & 35 & 1984 & 30 & 13727 & 48.914737 & -121.279530 \\
\hline 223402 & 2285 & & $0.057 \pm 0.006$ & 1983 & 32 & 2018 & 30 & 14324 & 48.916620 & -121.283824 \\
\hline 223403 & 2284 & & $0.056 \pm 0.006$ & 1983 & 30 & 1913 & 34 & 13781 & 48.919548 & -121.286050 \\
\hline 223404 & 2196 & & $0.064 \pm 0.007$ & 1983 & 32 & 1993 & 70 & 19346 & 48.922710 & -121.292058 \\
\hline 223405 & 2286 & & $0.145 \pm 0.010$ & 1983 & 28 & 1973 & 59 & 17387 & 48.926720 & -121.295501 \\
\hline 223406 & $2280 ; 2281$ & & $0.138 \pm 0.010$ & 1983 & 31 & 2037 & 50 & 15309 & 48.930865 & -121.301021 \\
\hline 223407 & 2478 & Redoubt Glacier & $0.550 \pm 0.019$ & 1983 & 18 & 2303 & 126 & 12395 & 48.952508 & -121.291710 \\
\hline 223408 & 2218 & & $0.100 \pm 0.008$ & 1983 & 29 & 2254 & 266 & 10864 & 48.945269 & -121.263801 \\
\hline 223501 & 2215 & & $0.052 \pm 0.006$ & 1968 & 23 & 1653 & 30 & 13819 & 48.941177 & -121.239455 \\
\hline 223502 & 2216 & & $0.523 \pm 0.019$ & 1983 & 29 & 2085 & 55 & 15538 & 48.942106 & -121.252580 \\
\hline 223503 & 2223 & & $0.226 \pm 0.012$ & 1983 & 32 & 2068 & 69 & 19037 & 48.950805 & -121.254945 \\
\hline 223504 & $2229 ; 2296$ & & $0.351 \pm 0.015$ & 1968 & 29 & 2375 & 148 & 15243 & 48.964260 & -121.241209 \\
\hline 223601 & 2295 & & $0.065 \pm 0.007$ & 1968 & 30 & 1676 & 16 & 11734 & 48.963873 & -121.217577 \\
\hline 223602 & 2230 & & $0.110 \pm 0.009$ & 1968 & 35 & 1863 & 52 & 17019 & 48.964400 & -121.226398 \\
\hline 223603 & 2235 & & $0.296 \pm 0.014$ & 1968 & 39 & 2223 & 72 & 11772 & 48.968509 & -121.232344 \\
\hline 223604 & 2241 & & $0.149 \pm 0.010$ & 1968 & 35 & 2114 & 109 & 17537 & 48.974990 & -121.229724 \\
\hline 223605 & 2242 & & $0.068 \pm 0.007$ & 1968 & 34 & 2361 & 318 & 4593 & 48.980172 & -121.232363 \\
\hline 223606 & 2292; 2294 & & $0.833 \pm 0.024$ & 1968 & 26 & 2277 & 334 & 6986 & 48.976303 & -121.242294 \\
\hline 223607 & 2291 & & $0.197 \pm 0.011$ & 1968 & 28 & 2342 & 120 & 7739 & 48.988969 & -121.244266 \\
\hline 223608 & 2270 & & $0.409 \pm 0.017$ & 1958 & 30 & 1907 & 32 & 8592 & 48.999798 & -121.216893 \\
\hline 223609 & 2269 & & $0.122 \pm 0.009$ & 1958 & 37 & 2371 & 11 & 4457 & 49.001916 & -121.227646 \\
\hline 223610 & 2268 & & $0.805 \pm 0.023$ & 1958 & 26 & 2211 & 355 & 5658 & 48.999843 & -121.239561 \\
\hline
\end{tabular}




\begin{tabular}{|c|c|c|c|c|c|c|c|c|c|c|}
\hline BasinID & RECNO (s) & Glacier Name & Area $\left(\mathrm{km}^{2}\right)$ & Year & $\mathrm{S}_{\text {mean }}$ & $Z_{\text {mean }}$ & $A_{\text {mean }}$ & $I_{\text {mean }}$ & Latitude & Longitude \\
\hline 223611 & 2265 & & $0.309 \pm 0.014$ & 1983 & 30 & 2251 & 336 & 9201 & 48.993071 & -121.250026 \\
\hline 223612 & 2264 & & $0.200 \pm 0.012$ & 1983 & 32 & 2143 & 352 & 11020 & 48.991760 & -121.259765 \\
\hline 223701 & 2134 & & $0.148 \pm 0.010$ & 1968 & 23 & 1604 & 6 & 13231 & 48.850619 & -121.138428 \\
\hline 223702 & 2131 & & $0.543 \pm 0.019$ & 1968 & 30 & 1989 & 24 & 10019 & 48.850840 & -121.156187 \\
\hline 223703 & 2136 & & $0.109 \pm 0.009$ & 1968 & 28 & 1711 & 348 & 12176 & 48.854903 & -121.165511 \\
\hline 224201 & 2381 & & $0.036 \pm 0.005$ & 1968 & 30 & 2062 & 16 & 9806 & 48.985448 & -120.862428 \\
\hline 224202 & 2372 & & $0.034 \pm 0.005$ & 1968 & 42 & 2204 & 21 & 7414 & 48.984583 & -120.865472 \\
\hline 224203 & 2379 & & $0.063 \pm 0.006$ & 1968 & 30 & 2079 & 3 & 7797 & 48.986770 & -120.869627 \\
\hline 224401 & 2045 & Jerry Glacier & $0.161 \pm 0.010$ & 1959 & 20 & 1991 & 9 & 13470 & 48.740817 & -120.903567 \\
\hline 224402 & 2045 & Jerry Glacier & $0.363 \pm 0.016$ & 1959 & 25 & 2128 & 31 & 9774 & 48.742676 & -120.916008 \\
\hline 224403 & 2047 & & $0.008 \pm 0.002$ & 1959 & 35 & 2071 & 56 & 17800 & 48.746788 & -120.921236 \\
\hline 224404 & 1937 & & $0.436 \pm 0.017$ & 1968 & 33 & 2036 & 33 & 12173 & 48.775965 & -120.944852 \\
\hline 224405 & 1929 & Nohokomeen Glacier & $1.801 \pm 0.035$ & 1968 & 23 & 2217 & 322 & 6543 & 48.779218 & -120.968515 \\
\hline 224501 & 1925 & & $0.018 \pm 0.003$ & 1968 & 37 & 2275 & 145 & 16059 & 48.768615 & -120.956469 \\
\hline 224502 & 1926 & & $0.212 \pm 0.012$ & 1968 & 25 & 2147 & 108 & 6822 & 48.770600 & -120.945268 \\
\hline 224601 & 3262 & & $0.057 \pm 0.006$ & 1958 & 36 & 2034 & 21 & 12289 & 48.509098 & -120.788119 \\
\hline 224602 & 3245 & Lewis Glacier & $0.172 \pm 0.011$ & 1958 & 27 & 2079 & 17 & 13261 & 48.511804 & -120.797087 \\
\hline 224603 & 3240 & & $0.081 \pm 0.007$ & 1958 & 31 & 2380 & 118 & 12111 & 48.525013 & -120.810372 \\
\hline 224604 & 3235 & & $0.064 \pm 0.007$ & 1958 & 39 & 1994 & 68 & 20304 & 48.528217 & -120.803854 \\
\hline 224605 & 3248 & & $0.056 \pm 0.006$ & 1958 & 34 & 2158 & 70 & 19803 & 48.531453 & -120.808377 \\
\hline 224606 & 3249 & & $0.077 \pm 0.007$ & 1958 & 41 & 2065 & 32 & 15858 & 48.534364 & -120.811945 \\
\hline 224607 & 3254 & & $0.044 \pm 0.005$ & 1958 & 33 & 2058 & 78 & 21340 & 48.546303 & -120.820017 \\
\hline 224608 & 3226 & & $0.076 \pm 0.007$ & 1958 & 29 & 1983 & 28 & 13495 & 48.578450 & -120.846385 \\
\hline 224609 & 3228 & & $0.060 \pm 0.006$ & 1958 & 34 & 2144 & 50 & 14963 & 48.579885 & -120.852690 \\
\hline 224610 & 2042 & & $0.027 \pm 0.004$ & 1959 & 23 & 1950 & 22 & 11832 & 48.665562 & -120.923577 \\
\hline 224701 & $3210 ; 3230$ & Mesahchie Glacier & $0.540 \pm 0.019$ & 1958 & 29 & 2127 & 348 & 9592 & 48.582611 & -120.869574 \\
\hline 224702 & 3185 & & $0.214 \pm 0.012$ & 1958 & 31 & 2127 & 332 & 12472 & 48.582925 & -120.882891 \\
\hline 224703 & 3178 & Katsuk Glacier & $0.810 \pm 0.023$ & 1958 & 24 & 2207 & 31 & 10199 & 48.582620 & -120.896804 \\
\hline 224704 & $3180 ; 3181 ; 3214$ & & $0.141 \pm 0.010$ & 1958 & 30 & 2079 & 45 & 15905 & 48.587207 & -120.900423 \\
\hline 224705 & $3182 ; 3184$ & Kimtah Glacier & $0.094 \pm 0.008$ & 1958 & 26 & 2101 & 348 & 8780 & 48.590913 & -120.905385 \\
\hline 224706 & 3182 & Kimtah Glacier & $0.831 \pm 0.024$ & 1958 & 31 & 2240 & 21 & 10839 & 48.589665 & -120.918149 \\
\hline 224707 & 3186 & & $0.059 \pm 0.006$ & 1958 & 28 & 1910 & 358 & 13280 & 48.591579 & -120.938133 \\
\hline 224708 & $3197 ; 3213$ & & $0.123 \pm 0.009$ & 1958 & 29 & 2113 & 55 & 16645 & 48.596275 & -120.978988 \\
\hline 224709 & 3203 & & $0.034 \pm 0.005$ & 1958 & 31 & 2154 & 46 & 14652 & 48.599659 & -120.983709 \\
\hline 224710 & 3201 & & $0.055 \pm 0.006$ & 1958 & 28 & 2109 & 48 & 14998 & 48.604187 & -120.987565 \\
\hline 224711 & $3206 ; 3207$ & & $0.060 \pm 0.006$ & 1958 & 28 & 2119 & 60 & 17531 & 48.607098 & -120.990236 \\
\hline 224712 & $3083 ; 3208 ; 3209$ & & $0.109 \pm 0.009$ & 1958 & 31 & 2081 & 24 & 11506 & 48.613581 & -120.996616 \\
\hline 224713 & 2037; 2038 & & $0.048 \pm 0.006$ & 1959 & 36 & 1976 & 357 & 10305 & 48.652688 & -120.962473 \\
\hline 224714 & 2036 & & $0.107 \pm 0.008$ & 1959 & 30 & 2070 & 42 & 16481 & 48.649261 & -120.953659 \\
\hline 224801 & 1623 & & $0.077 \pm 0.007$ & 1958 & 27 & 2085 & 10 & 10465 & 48.692262 & -121.036817 \\
\hline 225101 & 3255 & & $0.070 \pm 0.007$ & 1958 & 35 & 2139 & 348 & 11582 & 48.547767 & -120.825658 \\
\hline 225102 & 3256 & & $0.046 \pm 0.006$ & 1958 & 16 & 1874 & 327 & 16490 & 48.551629 & -120.829642 \\
\hline 225103 & 3257 & & $0.025 \pm 0.004$ & 1958 & 34 & 1842 & 25 & 12540 & 48.553561 & -120.837008 \\
\hline
\end{tabular}




\begin{tabular}{|c|c|c|c|c|c|c|c|c|c|c|}
\hline BasinID & RECNO (s) & Glacier Name & Area $\left(\mathrm{km}^{2}\right)$ & Year & $\mathrm{S}_{\text {mean }}$ & $\overline{Z_{\text {mean }}}$ & $A_{\text {mean }}$ & $I_{\text {mean }}$ & Latitude & Longitude \\
\hline 225104 & 3218 & & $0.025 \pm 0.004$ & 1958 & 42 & 2146 & 20 & 12528 & 48.551456 & -120.841299 \\
\hline 225105 & 3220 & & $0.169 \pm 0.011$ & 1958 & 31 & 2167 & 349 & 12462 & 48.550918 & -120.849115 \\
\hline 225106 & $3215 ; 3216$ & & $0.104 \pm 0.008$ & 1958 & 32 & 2003 & 20 & 12552 & 48.533865 & -120.869472 \\
\hline 225107 & 3150 & & $0.184 \pm 0.011$ & 1958 & 31 & 2198 & 1 & 9138 & 48.525586 & -120.910967 \\
\hline 225108 & 3211 & Banded-Douglas Glacier & $0.459 \pm 0.018$ & 1958 & 25 & 2100 & 14 & 8224 & 48.528089 & -120.925304 \\
\hline 225109 & 3211 & Banded-Douglas Glacier & $0.968 \pm 0.025$ & 1958 & 29 & 2247 & 85 & 14441 & 48.534635 & -120.941030 \\
\hline 225110 & $3174 ; 3175$ & & $0.194 \pm 0.011$ & 1958 & 38 & 2179 & 86 & 21320 & 48.544419 & -120.938668 \\
\hline 225111 & 3173 & & $0.189 \pm 0.011$ & 1958 & 26 & 1982 & 347 & 12474 & 48.550728 & -120.941892 \\
\hline 225112 & 3176 & & $0.067 \pm 0.007$ & 1958 & 38 & 2204 & 15 & 10580 & 48.548490 & -120.946716 \\
\hline 225113 & 3177 & & $0.200 \pm 0.012$ & 1958 & 33 & 2178 & 25 & 11585 & 48.551825 & -120.956332 \\
\hline 225114 & 3211 & Banded-Douglas Glacier & $0.728 \pm 0.022$ & 1958 & 21 & 2288 & 322 & 6992 & 48.543298 & -120.952727 \\
\hline 225115 & 3212 & Fremont Glacier & $0.948 \pm 0.025$ & 1958 & 19 & 2436 & 281 & 9186 & 48.531048 & -120.957590 \\
\hline 225201 & $3157 ; 3158 ; 3159$ & & $0.086 \pm 0.008$ & 1958 & 19 & 2283 & 205 & 1666 & 48.516378 & -120.954022 \\
\hline 225202 & 3152 & & $0.059 \pm 0.006$ & 1958 & 26 & 2011 & 311 & 12140 & 48.503581 & -120.955005 \\
\hline 225203 & $3168 ; 3170$ & Thunder Glacier & $0.227 \pm 0.012$ & 1958 & 35 & 1876 & 35 & 14430 & 48.502709 & -120.984755 \\
\hline 225204 & 3171 & Thunder Glacier & $0.166 \pm 0.011$ & 1958 & 33 & 2071 & 38 & 14367 & 48.505921 & -120.995344 \\
\hline 225205 & 3088 & Boston Glacier & $6.758 \pm 0.067$ & 1958 & 24 & 2132 & 23 & 7946 & 48.505570 & -121.026977 \\
\hline 225301 & 3044 & & $0.069 \pm 0.007$ & 1958 & 34 & 2244 & 334 & 9881 & 48.527005 & -121.043915 \\
\hline 225302 & (Granshaw and Fountain 2006) & & $0.138 \pm 0.010$ & 1958 & 34 & 2214 & 337 & 8308 & 48.525218 & -121.050193 \\
\hline 225303 & $3040 ; 3042 ; 3087$ & & $1.726 \pm 0.034$ & 1958 & 31 & 2083 & 325 & 10190 & 48.517605 & -121.066167 \\
\hline 225304 & 3039 & & $0.154 \pm 0.010$ & 1958 & 31 & 1976 & 4 & 8601 & 48.517785 & -121.089808 \\
\hline 225305 & 3041 & & $0.100 \pm 0.008$ & 1958 & 33 & 1935 & 25 & 12303 & 48.520307 & -121.097657 \\
\hline 225306 & 3361 & Inspiration Glacier & $4.479 \pm 0.055$ & 1958 & 23 & 2194 & 102 & 7648 & 48.538386 & -121.116036 \\
\hline 225307 & 3359 & & $0.547 \pm 0.019$ & 1958 & 26 & 2271 & 208 & 7852 & 48.548536 & -121.101156 \\
\hline 225308 & 3053 & & $0.118 \pm 0.009$ & 1958 & 31 & 2131 & 137 & 1883 & 48.545014 & -121.093188 \\
\hline 225309 & $3059 ; 3060$ & Klawatti Glacier & $2.203 \pm 0.038$ & 1958 & 27 & 2226 & 85 & 11318 & 48.557677 & -121.095602 \\
\hline 225310 & 3070 & North Klawatti Glacier & $1.758 \pm 0.034$ & 1958 & 17 & 2127 & 113 & 13671 & 48.572618 & -121.093802 \\
\hline 225401 & $3062 ; 3063$ & & $0.226 \pm 0.012$ & 1958 & 23 & 2050 & 36 & 12085 & 48.566918 & -121.060204 \\
\hline 225402 & 3069 & & $0.295 \pm 0.014$ & 1958 & 26 & 2164 & 74 & 12850 & 48.573036 & -121.069203 \\
\hline 225403 & 3073 & & $0.152 \pm 0.010$ & 1958 & 31 & 2063 & 77 & 21700 & 48.581495 & -121.072125 \\
\hline 225501 & 3077 & Borealis Glacier & $1.208 \pm 0.028$ & 1958 & 24 & 2054 & 33 & 12717 & 48.587587 & -121.085112 \\
\hline 225502 & 3078 & & $0.067 \pm 0.007$ & 1958 & 29 & 1938 & 0 & 10788 & 48.593840 & -121.090704 \\
\hline 225503 & 3076 & & $0.054 \pm 0.006$ & 1958 & 21 & 2256 & 268 & 12063 & 48.589544 & -121.098453 \\
\hline 225504 & 3074 & & $0.404 \pm 0.016$ & 1958 & 27 & 2210 & 306 & 9761 & 48.583738 & -121.099418 \\
\hline 225505 & 3072 & & $0.195 \pm 0.011$ & 1958 & 36 & 2034 & 358 & 10164 & 48.581026 & -121.114813 \\
\hline 225506 & $3084 ; 3085$ & & $0.178 \pm 0.011$ & 1958 & 26 & 1714 & 16 & 13837 & 48.582837 & -121.127080 \\
\hline 225507 & 3066 & & $0.053 \pm 0.006$ & 1958 & 28 & 2207 & 196 & 2313 & 48.577635 & -121.120434 \\
\hline 225508 & 3065 & & $0.098 \pm 0.008$ & 1958 & 28 & 2228 & 221 & 5655 & 48.576366 & -121.115711 \\
\hline 225509 & 3358 & McAllister Glacier & $4.971 \pm 0.058$ & 1958 & 24 & 2064 & 338 & 9429 & 48.560562 & -121.124638 \\
\hline 225510 & 3148 & & $0.299 \pm 0.014$ & 1958 & 32 & 1887 & 17 & 12078 & 48.565357 & -121.150217 \\
\hline 225511 & 3091 & & $0.099 \pm 0.008$ & 1958 & 32 & 1802 & 33 & 13273 & 48.567455 & -121.154392 \\
\hline 225512 & 3091 & & $0.874 \pm 0.024$ & 1958 & 30 & 1905 & 31 & 12902 & 48.570187 & -121.165285 \\
\hline 225513 & 3091 & & $0.124 \pm 0.009$ & 1958 & 26 & 1806 & 28 & 13044 & 48.574991 & -121.173807 \\
\hline
\end{tabular}




\begin{tabular}{|c|c|c|c|c|c|c|c|c|c|c|}
\hline BasinID & RECNO (s) & Glacier Name & Area $\left(\mathrm{km}^{2}\right)$ & Year & $\mathrm{S}_{\text {mean }}$ & $Z_{\text {mean }}$ & $A_{\text {mean }}$ & $I_{\text {mean }}$ & Latitude & Longitude \\
\hline 225514 & 3132 & & $0.216 \pm 0.012$ & 1958 & 32 & 1871 & 46 & 15833 & 48.576760 & -121.179256 \\
\hline 225601 & 1617 & & $0.184 \pm 0.011$ & 1958 & 32 & 1855 & 346 & 13381 & 48.638336 & -121.108008 \\
\hline 225602 & 2491 & Neve Glacier & $3.898 \pm 0.051$ & 1958 & 19 & 2096 & 52 & 9191 & 48.643996 & -121.140128 \\
\hline 225701 & $1621 ; 1762$ & Colonial Glacier & $1.039 \pm 0.026$ & 1958 & 19 & 1969 & 16 & 5712 & 48.661668 & -121.138663 \\
\hline 225702 & 1760 & & $0.199 \pm 0.012$ & 1958 & 25 & 2066 & 100 & 9841 & 48.669183 & -121.147267 \\
\hline 226101 & 3098 & & $0.056 \pm 0.006$ & 1958 & 25 & 2148 & 204 & 19697 & 48.564814 & -121.165326 \\
\hline 226102 & 3098 & & $0.071 \pm 0.007$ & 1958 & 31 & 2136 & 216 & 22257 & 48.562938 & -121.160894 \\
\hline 226103 & $3144 ; 3146$ & & $0.731 \pm 0.022$ & 1958 & 25 & 2231 & 256 & 18614 & 48.557125 & -121.147551 \\
\hline 226104 & 3099 & & $0.122 \pm 0.009$ & 1958 & 29 & 2241 & 196 & 14435 & 48.548726 & -121.143009 \\
\hline 226105 & 3101 & & $0.411 \pm 0.017$ & 1958 & 33 & 2231 & 272 & 14372 & 48.543323 & -121.136869 \\
\hline 226106 & $3111 ; 3112 ; 3114$ & & $0.201 \pm 0.012$ & 1958 & 35 & 1925 & 289 & 10600 & 48.529220 & -121.146312 \\
\hline 226107 & $3108 ; 3109 ; 3110$ & & $0.105 \pm 0.008$ & 1958 & 30 & 1854 & 263 & 10457 & 48.536513 & -121.145280 \\
\hline 226108 & 3122 & & $0.300 \pm 0.014$ & 1958 & 35 & 1870 & 333 & 10302 & 48.522809 & -121.156461 \\
\hline 226109 & $3104 ; 3106$ & & $0.267 \pm 0.013$ & 1958 & 29 & 1949 & 331 & 7130 & 48.518806 & -121.176797 \\
\hline 226110 & 3356 & & $0.405 \pm 0.016$ & 1983 & 17 & 1924 & 132 & 5618 & 48.570843 & -121.271181 \\
\hline 226201 & $3117 ; 3119 ; 3121$ & & $0.086 \pm 0.008$ & 1958 & 27 & 2106 & 183 & 13427 & 48.517383 & -121.161559 \\
\hline 226202 & $3116 ; 3120$ & & $0.082 \pm 0.007$ & 1958 & 32 & 2016 & 132 & 6536 & 48.519257 & -121.152965 \\
\hline 226203 & $3360 ; 3361$ & Eldorado Glacier & $2.025 \pm 0.037$ & 1958 & 20 & 2237 & 158 & 14224 & 48.528070 & -121.132792 \\
\hline 226205 & (Granshaw and Fountain 2006) & & $0.061 \pm 0.006$ & 1958 & 31 & 2049 & 243 & 12932 & 48.512953 & -121.085204 \\
\hline 226206 & (Granshaw and Fountain 2006) & & $0.070 \pm 0.007$ & 1958 & 29 & 2135 & 237 & 19765 & 48.510248 & -121.081115 \\
\hline 226207 & $3036 ; 3038$ & & $0.322 \pm 0.015$ & 1958 & 24 & 2166 & 191 & 11168 & 48.508788 & -121.071596 \\
\hline 226208 & 3037 & & $0.147 \pm 0.010$ & 1958 & 28 & 2282 & 210 & 14864 & 48.508469 & -121.061326 \\
\hline 226209 & 3089 & Quien Sabe Glacier & $0.677 \pm 0.021$ & 1958 & 26 & 2326 & 276 & 15094 & 48.494894 & -121.043239 \\
\hline 226210 & 2620 & & $0.055 \pm 0.006$ & 1958 & 36 & 1758 & 15 & 11913 & 48.463063 & -121.068693 \\
\hline 226211 & 2618 & & $0.060 \pm 0.006$ & 1958 & 39 & 1829 & 22 & 12080 & 48.464386 & -121.075692 \\
\hline 226212 & $2614 ; 2617$ & & $0.126 \pm 0.009$ & 1958 & 42 & 1654 & 19 & 13644 & 48.467428 & -121.084176 \\
\hline 226213 & 2608 & & $0.270 \pm 0.013$ & 1958 & 38 & 2137 & 15 & 12609 & 48.469136 & -121.094519 \\
\hline 226301 & 2612 & & $0.042 \pm 0.005$ & 1958 & 38 & 1941 & 221 & 11868 & 48.460392 & -121.094620 \\
\hline 226302 & 2590 & & $0.077 \pm 0.007$ & 1958 & 26 & 2070 & 302 & 8110 & 48.432252 & -121.042258 \\
\hline 226303 & 2561 & Middle Cascade Glacier & $0.988 \pm 0.026$ & 1958 & 27 & 1960 & 337 & 11018 & 48.417349 & -121.051927 \\
\hline 226304 & 2561 & Middle Cascade Glacier & $0.287 \pm 0.014$ & 1958 & 36 & 2037 & 35 & 14968 & 48.419138 & -121.062560 \\
\hline 226305 & 2562 & & $0.074 \pm 0.007$ & 1958 & 28 & 2110 & 319 & 8394 & 48.421707 & -121.068579 \\
\hline 226306 & 2563 & & $0.059 \pm 0.006$ & 1958 & 40 & 2218 & 312 & 7453 & 48.417399 & -121.070583 \\
\hline 226307 & 2564 & & $0.074 \pm 0.007$ & 1958 & 36 & 2191 & 315 & 10359 & 48.415263 & -121.073908 \\
\hline 226308 & 2565 & & $0.070 \pm 0.007$ & 1958 & 37 & 2023 & 319 & 10835 & 48.414584 & -121.081159 \\
\hline 226401 & 2554 & & $0.054 \pm 0.006$ & 1958 & 29 & 2174 & 212 & 16501 & 48.411340 & -121.061238 \\
\hline 226402 & 2557 & & $0.048 \pm 0.006$ & 1958 & 35 & 2267 & 243 & 22373 & 48.411107 & -121.058830 \\
\hline 226403 & 2632 & & $0.031 \pm 0.005$ & 1958 & 35 & 2152 & 341 & 8448 & 48.380712 & -121.065207 \\
\hline 226404 & 2775 & LeConte Glacier & $0.214 \pm 0.012$ & 1958 & 28 & 2181 & 280 & 12907 & 48.359298 & -121.044779 \\
\hline 226405 & 2819 & & $0.063 \pm 0.007$ & 1958 & 28 & 2228 & 262 & 17220 & 48.354080 & -121.044751 \\
\hline 226406 & 10480 & South Cascade Glacier & $2.924 \pm 0.044$ & 1958 & 13 & 1916 & 352 & 3623 & 48.356983 & -121.057349 \\
\hline 226407 & 10481 & & $0.492 \pm 0.018$ & 1958 & 31 & 2025 & 2 & 8385 & 48.359718 & -121.077324 \\
\hline 226408 & 2725 & & $0.549 \pm 0.019$ & 1958 & 23 & 1876 & 25 & 10590 & 48.363612 & -121.139971 \\
\hline
\end{tabular}




\begin{tabular}{|c|c|c|c|c|c|c|c|c|c|c|}
\hline BasinID & RECNO (s) & Glacier Name & Area $\left(\mathrm{km}^{2}\right)$ & Year & $\mathrm{S}_{\text {mean }}$ & $\overline{Z_{\text {mean }}}$ & $A_{\text {mean }}$ & $I_{\text {mean }}$ & Latitude & Longitude \\
\hline 226410 & 2510 & & $0.035 \pm 0.005$ & 1958 & 29 & 1709 & 358 & 15902 & 48.387256 & -121.142181 \\
\hline 226411 & $2508 ; 2509 ; 2511 ; 2512$ & & $0.089 \pm 0.008$ & 1958 & 27 & 1873 & 45 & 14654 & 48.389027 & -121.153381 \\
\hline 226412 & 2513 & & $0.062 \pm 0.006$ & 1958 & 32 & 1910 & 15 & 11181 & 48.391994 & -121.159421 \\
\hline 226413 & 2514 & & $0.047 \pm 0.006$ & 1958 & 31 & 1853 & 16 & 11203 & 48.393369 & -121.164261 \\
\hline 226501 & 2754 & & $0.193 \pm 0.011$ & 1958 & 30 & 1667 & 313 & 8436 & 48.362287 & -121.170537 \\
\hline 226502 & 2721 & & $0.819 \pm 0.023$ & 1958 & 30 & 1854 & 4 & 10298 & 48.356868 & -121.206487 \\
\hline 226503 & 2762 & & $0.072 \pm 0.007$ & 1958 & 24 & 1646 & 30 & 13235 & 48.361461 & -121.216616 \\
\hline 226504 & 2770 & & $0.053 \pm 0.006$ & 1958 & 30 & 1737 & 14 & 11874 & 48.367609 & -121.227237 \\
\hline 226505 & 2723 & & $0.116 \pm 0.009$ & 1958 & 27 & 1690 & 26 & 13118 & 48.369245 & -121.231834 \\
\hline 226601 & 2515 & & $0.047 \pm 0.006$ & 1958 & 34 & 1906 & 8 & 8837 & 48.396196 & -121.235333 \\
\hline 226602 & 2532 & & $1.088 \pm 0.027$ & 1963 & 25 & 1953 & 2 & 4737 & 48.393801 & -121.251639 \\
\hline 226603 & 2545 & & $0.117 \pm 0.009$ & 1963 & 26 & 1932 & 66 & 19575 & 48.400027 & -121.270456 \\
\hline 226604 & 2546 & & $0.036 \pm 0.005$ & 1963 & 34 & 2099 & 95 & 12274 & 48.405690 & -121.275369 \\
\hline 226701 & 2549 & & $0.254 \pm 0.013$ & 1963 & 23 & 2061 & 31 & 6061 & 48.410320 & -121.273835 \\
\hline 226702 & 2549 & & $0.735 \pm 0.022$ & 1963 & 25 & 2008 & 9 & 7528 & 48.409979 & -121.285279 \\
\hline 226803 & 2548 & & $0.090 \pm 0.008$ & 1963 & 26 & 2056 & 315 & 11684 & 48.407315 & -121.295965 \\
\hline 226804 & 2547 & & $0.069 \pm 0.007$ & 1963 & 32 & 2008 & 333 & 8693 & 48.405517 & -121.301746 \\
\hline 226904 & $2541 ; 2542 ; 2543$ & & $0.066 \pm 0.007$ & 1963 & 36 & 1763 & 358 & 10390 & 48.377815 & -121.316498 \\
\hline 226905 & 2544 & & $0.006 \pm 0.002$ & 1963 & 41 & 1756 & 0 & 10758 & 48.378736 & -121.325194 \\
\hline 227103 & 2738 & & $0.086 \pm 0.008$ & 1958 & 26 & 1971 & 289 & 16716 & 48.354531 & -121.221108 \\
\hline 227104 & 2739 & & $0.117 \pm 0.009$ & 1958 & 22 & 2076 & 192 & 18671 & 48.352050 & -121.212978 \\
\hline 227105 & 2741 & & $0.105 \pm 0.008$ & 1958 & 18 & 2069 & 257 & 19240 & 48.348516 & -121.204362 \\
\hline 227106 & 2724 & & $0.033 \pm 0.005$ & 1958 & 28 & 2046 & 310 & 11809 & 48.334494 & -121.199006 \\
\hline 227107 & 2737 & & $0.029 \pm 0.004$ & 1958 & 27 & 1876 & 347 & 10231 & 48.315056 & -121.219400 \\
\hline 227201 & 2733 & & $0.028 \pm 0.004$ & 1958 & 21 & 1678 & 146 & 25416 & 48.309554 & -121.224439 \\
\hline 227202 & 2745 & & $0.080 \pm 0.007$ & 1958 & 32 & 1985 & 111 & 7011 & 48.329543 & -121.197888 \\
\hline 227203 & 2750 & & $0.254 \pm 0.013$ & 1958 & 32 & 2000 & 112 & 8647 & 48.339218 & -121.192633 \\
\hline 227204 & 2752 & & $0.743 \pm 0.022$ & 1958 & 33 & 1857 & 67 & 19453 & 48.347468 & -121.195236 \\
\hline 227205 & 2507 & & $0.080 \pm 0.007$ & 1958 & 25 & 1732 & 63 & 21030 & 48.358900 & -121.130276 \\
\hline 227206 & 2793 & & $0.025 \pm 0.004$ & 1958 & 17 & 1724 & 268 & 4684 & 48.346420 & -121.069817 \\
\hline 227207 & 2849 & & $0.077 \pm 0.007$ & 1958 & 29 & 1982 & 342 & 6397 & 48.337258 & -121.073825 \\
\hline 227208 & 2783 & & $0.040 \pm 0.005$ & 1958 & 27 & 2155 & 302 & 14283 & 48.334115 & -121.072118 \\
\hline 227209 & 2847 & & $0.087 \pm 0.008$ & 1958 & 32 & 2106 & 286 & 7128 & 48.327182 & -121.069088 \\
\hline 227210 & 2781 & Spire Glacier & $0.928 \pm 0.025$ & 1958 & 29 & 2048 & 337 & 7854 & 48.321165 & -121.080139 \\
\hline 227211 & 2853 & & $0.105 \pm 0.008$ & 1958 & 31 & 1791 & 15 & 12187 & 48.323847 & -121.096116 \\
\hline 227212 & 2824 & & $0.031 \pm 0.005$ & 1958 & 14 & 1959 & 12 & 586 & 48.318719 & -121.096815 \\
\hline 227301 & 2856 & & $0.156 \pm 0.010$ & 1958 & 25 & 2179 & 195 & 18108 & 48.315350 & -121.081085 \\
\hline 227302 & 2859 & & $0.103 \pm 0.008$ & 1958 & 28 & 2234 & 180 & 14020 & 48.314202 & -121.073104 \\
\hline 227303 & 2846 & & $0.040 \pm 0.005$ & 1958 & 24 & 2316 & 225 & 24369 & 48.314571 & -121.069650 \\
\hline 227304 & 2868 & & $0.115 \pm 0.009$ & 1958 & 31 & 2133 & 183 & 11513 & 48.312586 & -121.060171 \\
\hline 227305 & 2869 & & $0.033 \pm 0.005$ & 1958 & 37 & 2216 & 212 & 17979 & 48.311677 & -121.054077 \\
\hline 227306 & 2834 & Dome Glacier & $1.062 \pm 0.027$ & 1958 & 22 & 2367 & 254 & 18892 & 48.305784 & -121.038771 \\
\hline 227307 & 2835 & & $0.121 \pm 0.009$ & 1958 & 29 & 2387 & 194 & 21853 & 48.299853 & -121.036973 \\
\hline
\end{tabular}




\begin{tabular}{|c|c|c|c|c|c|c|c|c|c|c|}
\hline BasinID & RECNO (s) & Glacier Name & Area $\left(\mathrm{km}^{2}\right)$ & Year & $\mathrm{S}_{\text {mean }}$ & $Z_{\text {mean }}$ & $A_{\text {mean }}$ & $I_{\text {mean }}$ & Latitude & Longitude \\
\hline 227308 & 10468 & & $0.181 \pm 0.011$ & 1958 & 33 & 2135 & 169 & 6576 & 48.298655 & -121.024943 \\
\hline 227309 & 2845 & & $0.110 \pm 0.009$ & 1958 & 34 & 2275 & 219 & 14140 & 48.299487 & -121.015969 \\
\hline 227310 & 2838 & & $0.325 \pm 0.015$ & 1958 & 20 & 2268 & 161 & 9312 & 48.296129 & -121.006985 \\
\hline 227311 & 2911 & & $0.095 \pm 0.008$ & 1958 & 28 & 2121 & 270 & 6675 & 48.256382 & -120.996705 \\
\hline 227312 & 2963 & & $0.324 \pm 0.015$ & 1984 & 23 & 2001 & 3 & 9501 & 48.246500 & -121.021494 \\
\hline 227313 & 3362 & & $0.218 \pm 0.012$ & 1984 & 25 & 2093 & 34 & 12408 & 48.248732 & -121.030938 \\
\hline 227402 & 2968 & & $0.171 \pm 0.011$ & 1984 & 27 & 1709 & 23 & 12821 & 48.169384 & -120.928175 \\
\hline 227501 & 3500 & & $0.155 \pm 0.010$ & 1984 & 22 & 2097 & 26 & 5769 & 48.109951 & -120.957481 \\
\hline 227502 & 3501 & & $0.053 \pm 0.006$ & 1984 & 22 & 2306 & 75 & 6560 & 48.107900 & -120.969688 \\
\hline 227503 & 3499 & & $0.046 \pm 0.006$ & 1984 & 32 & 2073 & 30 & 13268 & 48.112457 & -120.978969 \\
\hline 227504 & 3485 & & $0.043 \pm 0.005$ & 1984 & 20 & 2148 & 259 & 134 & 48.088098 & -121.002224 \\
\hline 227505 & 10472 & Butterfly Glacier & $0.413 \pm 0.017$ & 1984 & 29 & 2284 & 28 & 8341 & 48.079195 & -121.017200 \\
\hline 227506 & 3466 & & $0.314 \pm 0.015$ & 1984 & 36 & 2045 & 359 & 10949 & 48.081737 & -121.027536 \\
\hline 227507 & 3493 & & $0.027 \pm 0.004$ & 1984 & 45 & 2221 & 9 & 11091 & 48.079970 & -121.034170 \\
\hline 227508 & 3604 & Honeycomb Glacier & $3.432 \pm 0.048$ & 1984 & 15 & 2120 & 42 & 4401 & 48.073527 & -121.064302 \\
\hline 227601 & 3498 & & $0.143 \pm 0.010$ & 1984 & 30 & 2162 & 359 & 6851 & 48.085174 & -121.063578 \\
\hline 227602 & 3467 & & $0.171 \pm 0.011$ & 1984 & 29 & 2096 & 349 & 9852 & 48.084567 & -121.071172 \\
\hline 227603 & 9978 & Suiattle Glacier & $2.963 \pm 0.045$ & 1984 & 18 & 2190 & 17 & 2339 & 48.074270 & -121.092249 \\
\hline 227604 & 9979 & & $0.870 \pm 0.024$ & 1984 & 18 & 2238 & 94 & 4821 & 48.085637 & -121.105110 \\
\hline 227605 & 3602 & & $1.561 \pm 0.032$ & 1984 & 21 & 2459 & 143 & 19887 & 48.097179 & -121.102404 \\
\hline 227606 & 3600 & Cool Glacier & $1.698 \pm 0.034$ & 1984 & 25 & 2592 & 106 & 19652 & 48.106542 & -121.097731 \\
\hline 227607 & 3599 & Chocolate Glacier & $2.525 \pm 0.041$ & 1984 & 25 & 2456 & 72 & 7500 & 48.115111 & -121.092042 \\
\hline 227608 & 3598 & North Guardian Glacier & $1.087 \pm 0.027$ & 1984 & 24 & 2281 & 57 & 9956 & 48.122994 & -121.090968 \\
\hline 227609 & 3597 & Dusty Glacier & $1.376 \pm 0.030$ & 1984 & 25 & 2449 & 51 & 9680 & 48.126626 & -121.099712 \\
\hline 227701 & 3547 & & $0.279 \pm 0.014$ & 1984 & 22 & 2153 & 25 & 6847 & 48.136660 & -121.094008 \\
\hline 227702 & $3595 ; 3596$ & Ermine Glacier & $1.494 \pm 0.032$ & 1984 & 21 & 2281 & 3 & 5104 & 48.133786 & -121.106095 \\
\hline 227703 & 3595 & Vista Glacier & $1.009 \pm 0.026$ & 1984 & 23 & 2211 & 33 & 7287 & 48.136622 & -121.115085 \\
\hline 227801 & 3546 & & $0.139 \pm 0.010$ & 1984 & 24 & 1974 & 356 & 5185 & 48.150760 & -121.112231 \\
\hline 227802 & 3593 & Ptarmigan Glacier & $1.205 \pm 0.028$ & 1984 & 27 & 2158 & 350 & 8150 & 48.139165 & -121.127719 \\
\hline 227803 & 3440 & Milk Lake Glacier & $0.256 \pm 0.013$ & 1984 & 12 & 1864 & 88 & 11542 & 48.151242 & -121.155104 \\
\hline 227904 & 3445 & & $0.105 \pm 0.008$ & 1963 & 22 & 1786 & 347 & 6837 & 48.212983 & -121.418072 \\
\hline 228101 & 3594 & Kennedy Glacier & $1.569 \pm 0.032$ & 1984 & 28 & 2479 & 309 & 11136 & 48.124130 & -121.123257 \\
\hline 228102 & 3592 & Scimitar Glacier & $0.786 \pm 0.023$ & 1984 & 30 & 2462 & 320 & 9135 & 48.118135 & -121.129267 \\
\hline 228103 & 3534 & & $0.090 \pm 0.008$ & 1984 & 28 & 2282 & 261 & 22034 & 48.115027 & -121.137184 \\
\hline 228104 & 3464 & Sitkum Glacier & $0.355 \pm 0.015$ & 1984 & 26 & 2724 & 245 & 26786 & 48.109781 & -121.126181 \\
\hline 228105 & 3464 & Sitkum Glacier & $0.514 \pm 0.019$ & 1984 & 24 & 2262 & 296 & 15888 & 48.109905 & -121.138782 \\
\hline 228201 & 3464 & Sitkum Glacier & $0.365 \pm 0.016$ & 1984 & 31 & 2588 & 203 & 24222 & 48.103941 & -121.121917 \\
\hline 228202 & 3454 & & $0.247 \pm 0.013$ & 1984 & 27 & 2058 & 313 & 7840 & 48.078645 & -121.124810 \\
\hline 228203 & 3601 & White Chuck Glacier & $2.822 \pm 0.043$ & 1984 & 15 & 2145 & 279 & 9721 & 48.067106 & -121.113957 \\
\hline 228204 & 3528 & & $0.142 \pm 0.010$ & 1984 & 32 & 1966 & 15 & 10156 & 48.084741 & -121.203923 \\
\hline 228307 & 3444 & & $0.034 \pm 0.005$ & 1963 & 31 & 1836 & 358 & 10794 & 48.145571 & -121.379417 \\
\hline 228401 & 3505 & & $0.684 \pm 0.021$ & 1958 & 22 & 1641 & 29 & 14420 & 47.972325 & -121.328649 \\
\hline 228402 & 3506 & & $0.104 \pm 0.008$ & 1958 & 34 & 1775 & 66 & 17201 & 47.977113 & -121.337181 \\
\hline
\end{tabular}




\begin{tabular}{|c|c|c|c|c|c|c|c|c|c|c|}
\hline BasinID & RECNO (s) & Glacier Name & Area $\left(\mathrm{km}^{2}\right)$ & Year & $\mathrm{S}_{\text {mean }}$ & $Z_{\text {mean }}$ & $A_{\text {mean }}$ & $I_{\text {mean }}$ & Latitude & Longitude \\
\hline 228403 & 3523 & & $0.038 \pm 0.005$ & 1958 & 36 & 1836 & 56 & 13840 & 47.982799 & -121.341980 \\
\hline 228404 & 3522 & & $0.404 \pm 0.016$ & 1958 & 23 & 1488 & 66 & 19941 & 47.989503 & -121.337949 \\
\hline 228406 & 3438 & & $0.513 \pm 0.019$ & 1963 & 29 & 1950 & 57 & 14411 & 48.043745 & -121.333965 \\
\hline 228407 & 3438 & & $0.106 \pm 0.008$ & 1963 & 25 & 1883 & 59 & 15796 & 48.048020 & -121.336115 \\
\hline 228501 & 3519 & & $0.068 \pm 0.007$ & 1958 & 29 & 1585 & 23 & 12223 & 47.997045 & -121.351905 \\
\hline 228503 & 3521 & & $0.073 \pm 0.007$ & 1958 & 31 & 1935 & 37 & 12635 & 47.992564 & -121.348197 \\
\hline 228504 & 3520 & & $0.029 \pm 0.004$ & 1958 & 26 & 2094 & 342 & 6699 & 47.991826 & -121.352294 \\
\hline 228505 & 3518 & & $0.108 \pm 0.009$ & 1958 & 29 & 1737 & 22 & 12310 & 47.996534 & -121.359261 \\
\hline 228603 & 3516 & & $0.156 \pm 0.010$ & 1958 & 31 & 1833 & 360 & 9785 & 47.969645 & -121.353680 \\
\hline 228604 & 3517 & & $0.265 \pm 0.013$ & 1958 & 25 & 1916 & 291 & 14139 & 47.966096 & -121.362573 \\
\hline 231101 & $3424 ; 3426$ & So-Bahli-Alhi Glacier & $0.382 \pm 0.016$ & 1983 & 31 & 1812 & 352 & 8269 & 48.214668 & -121.680735 \\
\hline 231102 & 3423 & & $0.077 \pm 0.007$ & 1983 & 24 & 1589 & 300 & 10148 & 48.201022 & -121.675453 \\
\hline 231103 & 3418 & & $0.047 \pm 0.006$ & 1983 & 19 & 1343 & 350 & 15938 & 48.180518 & -121.688427 \\
\hline 231104 & 3419 & & $0.132 \pm 0.009$ & 1983 & 35 & 1804 & 1 & 9667 & 48.175795 & -121.690654 \\
\hline 231105 & 3420 & Quest-Alb Glacier & $0.649 \pm 0.021$ & 1983 & 25 & 1672 & 320 & 8474 & 48.170459 & -121.698054 \\
\hline 233101 & $3553 ; 3514$ & & $0.244 \pm 0.013$ & 1979 & 29 & 1389 & 318 & 16033 & 48.017917 & -121.520794 \\
\hline 233201 & (Granshaw and Fountain 2006) & & $0.043 \pm 0.005$ & 1958 & 27 & 1885 & 104 & 12635 & 47.950899 & -121.358726 \\
\hline 233202 & 3513 & & $0.037 \pm 0.005$ & 1958 & 29 & 1978 & 97 & 13270 & 47.954614 & -121.356846 \\
\hline 233203 & 3515 & & $0.058 \pm 0.006$ & 1958 & 37 & 2026 & 74 & 15371 & 47.960466 & -121.358743 \\
\hline 233204 & 3512 & Columbia Glacier & $0.803 \pm 0.023$ & 1958 & 15 & 1616 & 154 & 13235 & 47.962417 & -121.348465 \\
\hline 233205 & 3509 & & $0.087 \pm 0.008$ & 1958 & 29 & 1936 & 225 & 6278 & 47.968716 & -121.340693 \\
\hline 233206 & 3511 & & $0.071 \pm 0.007$ & 1958 & 27 & 2099 & 116 & 21574 & 47.962035 & -121.333502 \\
\hline 233207 & 3510 & & $0.017 \pm 0.003$ & 1958 & 34 & 2030 & 129 & 19799 & 47.963897 & -121.330505 \\
\hline 233208 & 3503 & & $0.122 \pm 0.009$ & 1958 & 18 & 1319 & 111 & 28010 & 47.965837 & -121.318288 \\
\hline 233209 & 3504 & & $0.053 \pm 0.006$ & 1958 & 21 & 1509 & 49 & 17984 & 47.970418 & -121.310273 \\
\hline 233401 & 3432 & & $0.116 \pm 0.009$ & 1958 & 19 & 1919 & 351 & 11029 & 47.585497 & -121.176865 \\
\hline 233402 & 3608 & Lynch Glacier & $0.878 \pm 0.024$ & 1958 & 19 & 2084 & 9 & 5515 & 47.572214 & -121.180507 \\
\hline 233403 & 3431 & & $0.133 \pm 0.009$ & 1958 & 32 & 1985 & 312 & 4732 & 47.571371 & -121.190610 \\
\hline 233404 & 3430 & & $0.291 \pm 0.014$ & 1958 & 18 & 1822 & 349 & 6582 & 47.570448 & -121.196340 \\
\hline 233405 & 3427 & & $0.905 \pm 0.025$ & 1958 & 20 & 2099 & 48 & 7369 & 47.571952 & -121.209701 \\
\hline 233406 & 3428 & & $0.141 \pm 0.010$ & 1958 & 24 & 1993 & 320 & 5111 & 47.576369 & -121.220347 \\
\hline 233407 & 3429 & Hinman Glacier & $1.259 \pm 0.029$ & 1958 & 16 & 1921 & 344 & 6819 & 47.574730 & -121.228776 \\
\hline 233408 & 3411 & & $0.021 \pm 0.004$ & 1958 & 22 & 1718 & 36 & 14635 & 47.554424 & -121.281377 \\
\hline 233409 & 3404 & & $0.087 \pm 0.008$ & 1958 & 20 & 1704 & 9 & 13335 & 47.555681 & -121.290870 \\
\hline 234203 & 3415 & & $0.142 \pm 0.010$ & 1958 & 24 & 1798 & 324 & 4403 & 47.522595 & -121.283024 \\
\hline 234204 & 3416 & & $0.376 \pm 0.016$ & 1958 & 20 & 1993 & 42 & 7137 & 47.516656 & -121.288942 \\
\hline 241302 & 3399 & & $0.127 \pm 0.009$ & 1957 & 34 & 1969 & 120 & 15132 & 47.489234 & -121.299865 \\
\hline 241303 & 3400 & & $0.163 \pm 0.010$ & 1957 & 32 & 1919 & 107 & 13596 & 47.494687 & -121.295897 \\
\hline 241304 & 3401 & & $0.034 \pm 0.005$ & 1957 & 32 & 1713 & 146 & 18114 & 47.497277 & -121.290612 \\
\hline 241305 & 3402 & & $0.460 \pm 0.018$ & 1958 & 29 & 1814 & 119 & 17133 & 47.502594 & -121.284939 \\
\hline 241306 & 3417 & & $0.158 \pm 0.010$ & 1958 & 26 & 1683 & 67 & 18653 & 47.509380 & -121.279716 \\
\hline 241307 & 3416 & & $0.214 \pm 0.012$ & 1958 & 22 & 2069 & 38 & 6069 & 47.511673 & -121.287716 \\
\hline 241501 & 3436 & & $0.192 \pm 0.011$ & 1958 & 19 & 2003 & 65 & 10474 & 47.559010 & -121.162270 \\
\hline
\end{tabular}




\begin{tabular}{|c|c|c|c|c|c|c|c|c|c|c|}
\hline BasinID & RECNO (s) & Glacier Name & Area $\left(\mathrm{km}^{2}\right)$ & Year & $\mathrm{S}_{\text {mean }}$ & $Z_{\text {mean }}$ & $A_{\text {mean }}$ & $I_{\text {mean }}$ & Latitude & Longitude \\
\hline 241502 & 3433 & & $0.049 \pm 0.006$ & 1958 & 25 & 2052 & 4 & 9805 & 47.565423 & -121.162763 \\
\hline 241503 & 3434 & & $0.038 \pm 0.005$ & 1958 & 29 & 2016 & 1 & 9843 & 47.566156 & -121.159347 \\
\hline 241504 & 3607 & & $0.435 \pm 0.017$ & 1958 & 25 & 2212 & 47 & 10332 & 47.566368 & -121.172187 \\
\hline 242201 & 3382 & & $0.050 \pm 0.006$ & 1957 & 33 & 2270 & 51 & 8078 & 47.472119 & -120.784918 \\
\hline 242202 & 3369 & & $0.111 \pm 0.009$ & 1957 & 26 & 2369 & 21 & 12803 & 47.487063 & -120.813042 \\
\hline 242203 & 3378 & & $0.118 \pm 0.009$ & 1957 & 21 & 2449 & 35 & 7028 & 47.471819 & -120.814654 \\
\hline 242204 & 3377 & Snow Creek Glacier & $0.058 \pm 0.006$ & 1957 & 23 & 2439 & 18 & 5147 & 47.473905 & -120.818758 \\
\hline 242205 & 3377 & Snow Creek Glacier & $0.047 \pm 0.006$ & 1957 & 22 & 2468 & 39 & 6274 & 47.473625 & -120.822061 \\
\hline 242206 & 3370 & & $0.036 \pm 0.005$ & 1957 & 28 & 2566 & 83 & 6606 & 47.475416 & -120.826456 \\
\hline 242207 & 3370 & & $0.095 \pm 0.008$ & 1957 & 28 & 2490 & 59 & 9878 & 47.478389 & -120.828608 \\
\hline 242208 & 3368 & Colchuck Glacier & $0.066 \pm 0.007$ & 1957 & 38 & 2265 & 1 & 11930 & 47.478798 & -120.838621 \\
\hline 242209 & 3368 & Colchuck Glacier & $0.114 \pm 0.009$ & 1957 & 32 & 2100 & 8 & 11577 & 47.480924 & -120.840082 \\
\hline 242210 & 3373 & & $0.021 \pm 0.004$ & 1957 & 33 & 2065 & 351 & 11336 & 47.470696 & -120.869167 \\
\hline 242211 & 3384 & Sherpa Glacier & $0.141 \pm 0.010$ & 1957 & 36 & 2166 & 30 & 13290 & 47.475423 & -120.890013 \\
\hline 242212 & 3395 & Stuart Glacier & $0.143 \pm 0.010$ & 1957 & 32 & 2235 & 22 & 10754 & 47.479602 & -120.901018 \\
\hline 242213 & 3391 & & $0.093 \pm 0.008$ & 1957 & 31 & 2277 & 49 & 10523 & 47.481016 & -120.909199 \\
\hline 242214 & 3390 & & $0.012 \pm 0.003$ & 1957 & 29 & 2326 & 73 & 5545 & 47.483156 & -120.911469 \\
\hline 242401 & 3566 & & $0.164 \pm 0.010$ & 1963 & 28 & 2312 & 79 & 6715 & 47.700484 & -120.930952 \\
\hline 242601 & 3437 & & $0.073 \pm 0.007$ & 1963 & 30 & 2038 & 341 & 8064 & 47.964245 & -120.991458 \\
\hline 242606 & 3588 & & $0.114 \pm 0.009$ & 1984 & 32 & 2002 & 357 & 10510 & 48.010750 & -121.086422 \\
\hline 242607 & 3589 & & $0.244 \pm 0.013$ & 1984 & 29 & 2001 & 11 & 10308 & 48.010968 & -121.095021 \\
\hline 242608 & 3590 & & $0.267 \pm 0.013$ & 1984 & 25 & 2094 & 355 & 3790 & 48.009320 & -121.103398 \\
\hline 242609 & 3591 & & $0.124 \pm 0.009$ & 1984 & 28 & 1955 & 345 & 5267 & 48.009331 & -121.111762 \\
\hline 242610 & 3603 & White River Glacier & $1.291 \pm 0.029$ & 1984 & 17 & 2258 & 191 & 16429 & 48.058131 & -121.095750 \\
\hline 242611 & 3603 & White River Glacier & $0.328 \pm 0.015$ & 1984 & 15 & 2175 & 84 & 9177 & 48.054037 & -121.085432 \\
\hline 242612 & 3604 & Honeycomb Glacier & $0.526 \pm 0.019$ & 1984 & 21 & 2314 & 90 & 13731 & 48.063400 & -121.074275 \\
\hline 242701 & 10475 & Clark Glacier & $1.312 \pm 0.030$ & 1984 & 26 & 2267 & 26 & 9520 & 48.049334 & -120.954284 \\
\hline 242703 & 10474 & Richardson Glacier & $0.746 \pm 0.022$ & 1984 & 22 & 2259 & 54 & 9573 & 48.056361 & -120.974305 \\
\hline 242704 & 3492 & & $0.060 \pm 0.006$ & 1984 & 26 & 1896 & 49 & 17431 & 48.062927 & -120.969817 \\
\hline 242705 & 3492 & & $0.074 \pm 0.007$ & 1984 & 24 & 1999 & 64 & 20332 & 48.063417 & -120.974148 \\
\hline 242706 & 10473 & Pit Glacier & $0.905 \pm 0.025$ & 1984 & 22 & 2241 & 70 & 8931 & 48.066208 & -120.982565 \\
\hline 242707 & 10472 & Butterfly Glacier & $1.287 \pm 0.029$ & 1984 & 27 & 2222 & 1 & 7830 & 48.069404 & -120.998128 \\
\hline 242708 & 10472 & Butterfly Glacier & $0.424 \pm 0.017$ & 1984 & 28 & 2296 & 55 & 12958 & 48.074577 & -121.010795 \\
\hline 242709 & 3489 & & $0.142 \pm 0.010$ & 1984 & 16 & 2478 & 265 & 14385 & 48.090637 & -120.915354 \\
\hline 242801 & 3490 & & $0.080 \pm 0.007$ & 1984 & 24 & 2273 & 60 & 10968 & 48.063738 & -120.903184 \\
\hline 242802 & 3491 & & $0.319 \pm 0.015$ & 1984 & 28 & 2091 & 47 & 15552 & 48.070829 & -120.910468 \\
\hline 242803 & 3488 & & $0.089 \pm 0.008$ & 1984 & 35 & 2311 & 61 & 15489 & 48.092005 & -120.907659 \\
\hline 242804 & 3502 & & $0.127 \pm 0.009$ & 1984 & 32 & 1795 & 4 & 11298 & 48.097559 & -120.916015 \\
\hline 242805 & 2971 & Spider Glacier & $0.057 \pm 0.006$ & 1984 & 22 & 1956 & 115 & 24233 & 48.162640 & -120.879981 \\
\hline 243101 & 2998 & & $0.019 \pm 0.004$ & 1984 & 25 & 1794 & 359 & 12091 & 48.099520 & -120.759079 \\
\hline 243102 & $2999 ; 3000$ & & $0.106 \pm 0.008$ & 1984 & 33 & 2126 & 12 & 11737 & 48.098442 & -120.769437 \\
\hline 243103 & $3001 ; 3002 ; 3003$ & & $0.087 \pm 0.008$ & 1984 & 34 & 2085 & 23 & 11987 & 48.101342 & -120.776491 \\
\hline 243104 & 3005 & & $0.056 \pm 0.006$ & 1984 & 28 & 2221 & 47 & 14132 & 48.104379 & -120.791227 \\
\hline
\end{tabular}




\begin{tabular}{|c|c|c|c|c|c|c|c|c|c|c|}
\hline BasinID & RECNO (s) & Glacier Name & Area $\left(\mathrm{km}^{2}\right)$ & Year & $\mathrm{S}_{\text {mean }}$ & $Z_{\text {mean }}$ & $A_{\text {mean }}$ & $I_{\text {mean }}$ & Latitude & Longitude \\
\hline 243105 & $3006 ; 3007$ & & $0.094 \pm 0.008$ & 1984 & 30 & 2241 & 38 & 14319 & 48.114804 & -120.796174 \\
\hline 243106 & 2985 & & $0.084 \pm 0.007$ & 1984 & 22 & 2262 & 28 & 5055 & 48.126293 & -120.802909 \\
\hline 243201 & 2980 & & $0.125 \pm 0.009$ & 1984 & 24 & 2157 & 26 & 12251 & 48.131958 & -120.761892 \\
\hline 243202 & 2982 & & $0.121 \pm 0.009$ & 1984 & 27 & 2185 & 15 & 12052 & 48.137164 & -120.774053 \\
\hline 243203 & 2984 & Entiat Glacier & $0.803 \pm 0.023$ & 1984 & 32 & 2260 & 13 & 9487 & 48.141031 & -120.795035 \\
\hline 243204 & 2975 & & $0.331 \pm 0.015$ & 1984 & 26 & 1936 & 68 & 20704 & 48.148368 & -120.802902 \\
\hline 243205 & 2990 & & $0.141 \pm 0.010$ & 1984 & 31 & 2322 & 134 & 13865 & 48.156717 & -120.806363 \\
\hline 244201 & 2989 & & $0.178 \pm 0.011$ & 1984 & 30 & 2412 & 52 & 8646 & 48.164346 & -120.797432 \\
\hline 244202 & 2988 & & $0.200 \pm 0.012$ & 1984 & 33 & 2205 & 57 & 16330 & 48.171924 & -120.795710 \\
\hline 244204 & 2987 & & $0.186 \pm 0.011$ & 1984 & 32 & 2348 & 335 & 13949 & 48.166768 & -120.808242 \\
\hline 244205 & 2977 & & $0.238 \pm 0.013$ & 1984 & 28 & 2184 & 337 & 8029 & 48.154487 & -120.821305 \\
\hline 244207 & 2993 & & $0.192 \pm 0.011$ & 1984 & 29 & 2389 & 86 & 13596 & 48.186601 & -120.847250 \\
\hline 244209 & 2991 & & $0.036 \pm 0.005$ & 1984 & 28 & 2037 & 6 & 11334 & 48.193773 & -120.838703 \\
\hline 244210 & 2992 & & $0.084 \pm 0.008$ & 1984 & 35 & 2174 & 34 & 13359 & 48.192491 & -120.845396 \\
\hline 244211 & 3012 & & $0.044 \pm 0.005$ & 1984 & 41 & 2378 & 357 & 8626 & 48.181470 & -120.860988 \\
\hline 244212 & 2971 & Spider Glacier & $0.058 \pm 0.006$ & 1984 & 23 & 2126 & 123 & 14636 & 48.167691 & -120.881820 \\
\hline 244213 & 2967 & Lyman Glacier & $0.464 \pm 0.018$ & 1984 & 20 & 1957 & 16 & 11475 & 48.171757 & -120.896359 \\
\hline 244214 & 2969 & & $0.073 \pm 0.007$ & 1984 & 41 & 2269 & 54 & 17211 & 48.175300 & -120.908579 \\
\hline 244215 & 2970 & & $0.117 \pm 0.009$ & 1984 & 38 & 2133 & 36 & 13827 & 48.178992 & -120.910784 \\
\hline 244217 & 2995 & Isella Glacier & $0.527 \pm 0.019$ & 1984 & 26 & 2483 & 153 & 14562 & 48.233326 & -120.868164 \\
\hline 244218 & 2997 & Mary Green Glacier & $0.564 \pm 0.019$ & 1984 & 26 & 2398 & 89 & 13067 & 48.238056 & -120.856856 \\
\hline 244220 & 2996 & & $0.075 \pm 0.007$ & 1984 & 32 & 2186 & 77 & 21027 & 48.246290 & -120.851436 \\
\hline 244221 & 2918 & Company Glacier & $1.252 \pm 0.029$ & 1984 & 32 & 2202 & 33 & 13632 & 48.246986 & -120.868434 \\
\hline 244222 & 2994 & & $0.207 \pm 0.012$ & 1984 & 27 & 2357 & 71 & 14341 & 48.240425 & -120.811307 \\
\hline 244223 & 2933 & & $0.015 \pm 0.003$ & 1958 & 36 & 2215 & 20 & 11284 & 48.252656 & -120.762192 \\
\hline 244301 & 2937 & & $0.005 \pm 0.002$ & 1958 & 41 & 2091 & 24 & 12287 & 48.280768 & -120.863976 \\
\hline 244302 & 2913 & Dark Glacier & $0.678 \pm 0.021$ & 1958 & 34 & 2188 & 2 & 11798 & 48.259384 & -120.886773 \\
\hline 244303 & 2974 & Grant Glacier & $0.364 \pm 0.016$ & 1984 & 26 & 2219 & 11 & 7296 & 48.226544 & -120.899014 \\
\hline 244306 & 2910 & & $0.063 \pm 0.006$ & 1958 & 28 & 2099 & 359 & 5686 & 48.264343 & -120.960445 \\
\hline 244307 & 2877 & & $0.264 \pm 0.013$ & 1958 & 25 & 1711 & 27 & 13863 & 48.258025 & -120.983499 \\
\hline 244308 & 2919 & & $0.222 \pm 0.012$ & 1958 & 23 & 2267 & 126 & 7476 & 48.296552 & -120.999377 \\
\hline 244401 & 2900 & & $0.139 \pm 0.010$ & 1958 & 26 & 1784 & 33 & 14666 & 48.311722 & -120.958987 \\
\hline 244402 & 2891 & & $0.120 \pm 0.009$ & 1958 & 14 & 1720 & 342 & 16090 & 48.310536 & -120.978013 \\
\hline 244403 & 2897 & Blue Glacier & $0.354 \pm 0.015$ & 1958 & 31 & 2230 & 54 & 14191 & 48.308378 & -120.990946 \\
\hline 244404 & 2876 & & $0.145 \pm 0.010$ & 1958 & 31 & 2032 & 280 & 358 & 48.317995 & -120.999962 \\
\hline 244405 & 2883 & & $0.017 \pm 0.003$ & 1958 & 21 & 2157 & 239 & 133 & 48.314389 & -120.996562 \\
\hline 244406 & 2893 & & $0.088 \pm 0.008$ & 1958 & 35 & 2154 & 297 & 8355 & 48.311351 & -120.997449 \\
\hline 244407 & 10467 & Chickamin Glacier & $4.845 \pm 0.057$ & 1958 & 24 & 2107 & 15 & 9800 & 48.311192 & -121.015776 \\
\hline 244408 & 2792 & Dana Glacier & $1.584 \pm 0.033$ & 1958 & 24 & 2099 & 3 & 8311 & 48.316682 & -121.046761 \\
\hline 244409 & 2792 & Dana Glacier & $0.938 \pm 0.025$ & 1958 & 27 & 2164 & 59 & 11249 & 48.321515 & -121.062800 \\
\hline 244410 & 2784 & & $0.049 \pm 0.006$ & 1958 & 32 & 2158 & 66 & 17925 & 48.331489 & -121.068466 \\
\hline 244411 & 2787 & & $0.055 \pm 0.006$ & 1958 & 32 & 2088 & 102 & 22016 & 48.335672 & -121.067403 \\
\hline 244412 & 2798 & & $0.050 \pm 0.006$ & 1958 & 24 & 1959 & 103 & 23560 & 48.341837 & -121.062327 \\
\hline
\end{tabular}




\begin{tabular}{|c|c|c|c|c|c|c|c|c|c|c|}
\hline BasinID & RECNO (s) & Glacier Name & Area $\left(\mathrm{km}^{2}\right)$ & Year & $\mathrm{S}_{\text {mean }}$ & $Z_{\text {mean }}$ & $A_{\text {mean }}$ & $I_{\text {mean }}$ & Latitude & Longitude \\
\hline 244413 & 2799 & & $0.043 \pm 0.005$ & 1958 & 19 & 1922 & 191 & 3 & 48.342422 & -121.050066 \\
\hline 244414 & 2805 & & $0.077 \pm 0.007$ & 1958 & 35 & 2063 & 122 & 16692 & 48.351555 & -121.039497 \\
\hline 244415 & 2775 & LeConte Glacier & $0.117 \pm 0.009$ & 1958 & 29 & 2344 & 110 & 10820 & 48.355141 & -121.030974 \\
\hline 244416 & 2820 & & $0.116 \pm 0.009$ & 1958 & 39 & 2086 & 104 & 24168 & 48.356833 & -121.026044 \\
\hline 244417 & 2775 & LeConte Glacier & $0.242 \pm 0.013$ & 1958 & 31 & 2159 & 79 & 13619 & 48.362794 & -121.023975 \\
\hline 244501 & 2821 & & $0.027 \pm 0.004$ & 1958 & 20 & 1647 & 3 & 14455 & 48.372960 & -121.010442 \\
\hline 244502 & 2822 & & $0.030 \pm 0.005$ & 1958 & 27 & 1928 & 347 & 11660 & 48.368987 & -121.021274 \\
\hline 244503 & 2775 & LeConte Glacier & $0.165 \pm 0.011$ & 1958 & 28 & 2128 & 23 & 7774 & 48.366944 & -121.026007 \\
\hline 244504 & 2775 & LeConte Glacier & $1.581 \pm 0.033$ & 1958 & 23 & 2194 & 345 & 8244 & 48.363878 & -121.036953 \\
\hline 244505 & 2552 & & $0.331 \pm 0.015$ & 1958 & 30 & 2066 & 68 & 19393 & 48.378303 & -121.054803 \\
\hline 244506 & 2555 & & $0.031 \pm 0.005$ & 1958 & 27 & 2017 & 72 & 21072 & 48.402777 & -121.060135 \\
\hline 244507 & 2556 & & $0.141 \pm 0.010$ & 1958 & 32 & 2170 & 177 & 6441 & 48.410019 & -121.051834 \\
\hline 244508 & 2578 & & $0.145 \pm 0.010$ & 1958 & 30 & 2238 & 118 & 16080 & 48.406409 & -121.032279 \\
\hline 244509 & 2577 & & $0.023 \pm 0.004$ & 1958 & 42 & 2056 & 97 & 23466 & 48.408590 & -121.020166 \\
\hline 244510 & 2576 & & $0.050 \pm 0.006$ & 1958 & 39 & 1843 & 6 & 12951 & 48.412189 & -121.018302 \\
\hline 244511 & 2572 & Spider Glacier & $0.245 \pm 0.013$ & 1958 & 33 & 2008 & 358 & 11209 & 48.412289 & -121.025970 \\
\hline 244512 & 2572 & Spider Glacier & $0.314 \pm 0.015$ & 1958 & 35 & 2039 & 22 & 12028 & 48.414425 & -121.036448 \\
\hline 244513 & 2569 & & $0.036 \pm 0.005$ & 1958 & 31 & 2154 & 42 & 12953 & 48.417905 & -121.044169 \\
\hline 244514 & 2568 & & $0.056 \pm 0.006$ & 1958 & 32 & 1921 & 73 & 21288 & 48.420752 & -121.042669 \\
\hline 244515 & 2571 & & $0.102 \pm 0.008$ & 1958 & 22 & 1653 & 59 & 18920 & 48.420380 & -121.035983 \\
\hline 244516 & 2573 & & $0.099 \pm 0.008$ & 1958 & 15 & 1338 & 98 & 26587 & 48.421328 & -121.025686 \\
\hline 244517 & 2575 & & $0.046 \pm 0.006$ & 1958 & 30 & 1159 & 29 & 13640 & 48.419025 & -121.007521 \\
\hline 244518 & 2587 & & $0.019 \pm 0.004$ & 1958 & 35 & 2086 & 185 & 508 & 48.429956 & -121.037408 \\
\hline 244519 & 2586 & & $0.024 \pm 0.004$ & 1958 & 38 & 2013 & 106 & 20329 & 48.430986 & -121.028868 \\
\hline 244601 & 2664 & & $0.093 \pm 0.008$ & 1958 & 30 & 1925 & 334 & 12489 & 48.434029 & -120.980205 \\
\hline 244602 & 2585 & South Glacier & $0.278 \pm 0.014$ & 1958 & 35 & 2069 & 34 & 12802 & 48.434481 & -121.033126 \\
\hline 244603 & 2583 & S Glacier & $0.129 \pm 0.009$ & 1958 & 27 & 1587 & 68 & 20818 & 48.440407 & -121.029094 \\
\hline 244604 & 2582 & & $0.075 \pm 0.007$ & 1958 & 22 & 1591 & 126 & 28727 & 48.448105 & -121.023612 \\
\hline 244605 & 2594 & & $0.024 \pm 0.004$ & 1958 & 28 & 2006 & 100 & 10227 & 48.448051 & -121.030165 \\
\hline 244606 & 2595 & & $0.032 \pm 0.005$ & 1958 & 29 & 2019 & 131 & 3306 & 48.446769 & -121.033034 \\
\hline 244607 & $2598 ; 2603$ & Yawning Glacier & $0.160 \pm 0.010$ & 1958 & 30 & 1831 & 359 & 12690 & 48.449491 & -121.038458 \\
\hline 244608 & 2602 & & $0.060 \pm 0.006$ & 1958 & 33 & 2004 & 18 & 13108 & 48.449513 & -121.048475 \\
\hline 244609 & $2604 ; 2622$ & & $0.293 \pm 0.014$ & 1958 & 26 & 1957 & 43 & 15182 & 48.453529 & -121.055023 \\
\hline 244610 & 3282 & Sahale Glacier & $0.155 \pm 0.010$ & 1958 & 28 & 2416 & 173 & 25327 & 48.487673 & -121.040945 \\
\hline 244611 & 3274 & Davenport Glacier & $0.264 \pm 0.013$ & 1958 & 27 & 2278 & 138 & 10191 & 48.492188 & -121.030333 \\
\hline 244612 & 3272 & & $0.032 \pm 0.005$ & 1958 & 27 & 2208 & 265 & 7607 & 48.482759 & -120.999838 \\
\hline 244613 & 2636 & & $0.134 \pm 0.009$ & 1958 & 19 & 2286 & 291 & 7012 & 48.478513 & -120.991513 \\
\hline 244614 & $2637 ; 2655$ & & $0.078 \pm 0.007$ & 1958 & 20 & 2168 & 178 & 2828 & 48.473908 & -120.990924 \\
\hline 244615 & $2651 ; 2656$ & & $0.038 \pm 0.005$ & 1958 & 26 & 2328 & 197 & 15234 & 48.471631 & -120.975740 \\
\hline 244616 & 2658 & & $0.053 \pm 0.006$ & 1958 & 39 & 2143 & 40 & 13826 & 48.469464 & -120.966486 \\
\hline 244617 & 2650 & & $0.052 \pm 0.006$ & 1958 & 38 & 1859 & 33 & 14027 & 48.473997 & -120.967959 \\
\hline 244618 & 2639 & & $0.021 \pm 0.004$ & 1958 & 45 & 1692 & 43 & 15055 & 48.479315 & -120.974669 \\
\hline 244619 & 3306 & & $0.029 \pm 0.004$ & 1958 & 23 & 1566 & 68 & 21527 & 48.484247 & -120.978683 \\
\hline
\end{tabular}




\begin{tabular}{|c|c|c|c|c|c|c|c|c|c|c|}
\hline BasinlD & RECNO (s) & Glacier Name & Area $\left(\mathrm{km}^{2}\right)$ & Year & $\mathrm{S}_{\text {mean }}$ & $Z_{\text {mean }}$ & $A_{\text {mean }}$ & $I_{\text {mean }}$ & Latitude & Longitude \\
\hline 244620 & $3307 ; 3309$ & & $0.269 \pm 0.013$ & 1958 & 27 & 2013 & 62 & 19194 & 48.483666 & -120.990238 \\
\hline 244621 & 3309 & Buckner Glacier & $0.293 \pm 0.014$ & 1958 & 34 & 2340 & 125 & 17207 & 48.489827 & -120.995724 \\
\hline 244622 & 3287 & & $0.275 \pm 0.014$ & 1958 & 35 & 2239 & 120 & 19022 & 48.495458 & -120.990164 \\
\hline 244623 & $3304 ; 3305$ & & $0.082 \pm 0.007$ & 1958 & 30 & 2292 & 245 & 6209 & 48.483853 & -120.919697 \\
\hline 244624 & 2647 & & $0.019 \pm 0.004$ & 1958 & 24 & 2122 & 80 & 21105 & 48.473577 & -120.906225 \\
\hline 244625 & 2648 & & $0.013 \pm 0.003$ & 1958 & 36 & 2174 & 44 & 14291 & 48.471774 & -120.906093 \\
\hline 244701 & 2645 & & $0.035 \pm 0.005$ & 1958 & 35 & 2122 & 67 & 19728 & 48.478254 & -120.889991 \\
\hline 244702 & 3311 & & $0.068 \pm 0.007$ & 1958 & 36 & 2222 & 79 & 16972 & 48.481529 & -120.892250 \\
\hline 244703 & $3297 ; 3298 ; 3301 ; 3302$ & & $0.584 \pm 0.020$ & 1958 & 35 & 1970 & 27 & 12978 & 48.487228 & -120.903460 \\
\hline 244704 & 3296 & & $0.197 \pm 0.011$ & 1958 & 37 & 2167 & 26 & 13721 & 48.489526 & -120.916929 \\
\hline 244705 & 3284 & & $0.045 \pm 0.006$ & 1958 & 41 & 1639 & 34 & 13918 & 48.496498 & -120.915675 \\
\hline 244706 & 3283 & & $0.018 \pm 0.003$ & 1958 & 32 & 1912 & 37 & 15297 & 48.496788 & -120.926075 \\
\hline 244707 & 3292 & & $0.069 \pm 0.007$ & 1958 & 37 & 2457 & 149 & 15219 & 48.490611 & -120.927820 \\
\hline 244708 & $3156 ; 3285$ & Wyeth Glacier & $0.841 \pm 0.024$ & 1958 & 29 & 2252 & 32 & 12041 & 48.495332 & -120.940589 \\
\hline 244709 & 3155 & & $0.104 \pm 0.008$ & 1958 & 36 & 2068 & 62 & 17824 & 48.511117 & -120.945782 \\
\hline 244710 & $3161 ; 3162 ; 3163 ; 3164 ; 3165$ & & $0.251 \pm 0.013$ & 1958 & 36 & 2245 & 119 & 15249 & 48.524763 & -120.947603 \\
\hline 244711 & 3247 & & $0.049 \pm 0.006$ & 1958 & 34 & 2321 & 325 & 10302 & 48.529220 & -120.812261 \\
\hline 244712 & 3242 & & $0.247 \pm 0.013$ & 1958 & 34 & 2155 & 341 & 12484 & 48.527464 & -120.820207 \\
\hline 244713 & 3234 & & $0.078 \pm 0.007$ & 1958 & 25 & 2214 & 322 & 3082 & 48.504098 & -120.793194 \\
\hline 244714 & $3315 ; 3316 ; 3317$ & & $0.082 \pm 0.007$ & 1958 & 28 & 2080 & 349 & 10815 & 48.492862 & -120.818588 \\
\hline 244801 & 3314 & & $0.033 \pm 0.005$ & 1958 & 19 & 1898 & 67 & 22068 & 48.497327 & -120.755178 \\
\hline 244802 & 3319 & & $0.036 \pm 0.005$ & 1958 & 27 & 2190 & 59 & 16719 & 48.489959 & -120.754465 \\
\hline 244803 & 3320 & Lyell Glacier & $0.252 \pm 0.013$ & 1968 & 26 & 2057 & 11 & 12535 & 48.488253 & -120.745696 \\
\hline 244804 & 3326 & & $0.021 \pm 0.004$ & 1968 & 17 & 1968 & 66 & 23022 & 48.488464 & -120.734143 \\
\hline 244805 & $2687 ; 2692$ & & $0.141 \pm 0.010$ & 1958 & 36 & 2099 & 28 & 12655 & 48.406639 & -120.775159 \\
\hline 244806 & $2686 ; 2694$ & & $0.064 \pm 0.007$ & 1958 & 33 & 2127 & 36 & 13690 & 48.409134 & -120.780257 \\
\hline 244807 & 2693 & Sandalee Glacier & $0.101 \pm 0.008$ & 1958 & 31 & 2192 & 4 & 10207 & 48.408514 & -120.784353 \\
\hline 244808 & 2696 & Sandalee Glacier & $0.216 \pm 0.012$ & 1958 & 26 & 2158 & 10 & 9712 & 48.409341 & -120.789954 \\
\hline 244809 & 2695 & Sandalee Glacier & $0.090 \pm 0.008$ & 1958 & 32 & 2302 & 38 & 9693 & 48.409159 & -120.795142 \\
\hline 244810 & 2695 & Sandalee Glacier & $0.165 \pm 0.011$ & 1958 & 28 & 2260 & 29 & 9024 & 48.411269 & -120.797997 \\
\hline 244811 & 2685 & & $0.022 \pm 0.004$ & 1958 & 23 & 2235 & 295 & 6524 & 48.409712 & -120.804428 \\
\hline 245101 & 2534 & & $0.039 \pm 0.005$ & 1968 & 35 & 2351 & 22 & 10311 & 48.252727 & -120.428273 \\
\hline 245302 & 3271 & & $0.075 \pm 0.007$ & 1985 & 34 & 2418 & 360 & 9516 & 48.507955 & -120.484308 \\
\hline 245303 & 3270 & & $0.068 \pm 0.007$ & 1958 & 29 & 2222 & 21 & 11015 & 48.549704 & -120.574034 \\
\hline 245304 & 3266 & & $0.109 \pm 0.009$ & 1958 & 33 & 2391 & 34 & 6969 & 48.550433 & -120.581819 \\
\hline 245305 & 3265 & & $0.092 \pm 0.008$ & 1958 & 29 & 2440 & 27 & 6352 & 48.551571 & -120.586285 \\
\hline 245306 & 3265 & & $0.024 \pm 0.004$ & 1958 & 35 & 2383 & 43 & 6959 & 48.553664 & -120.588578 \\
\hline 245307 & 3265 & & $0.034 \pm 0.005$ & 1958 & 32 & 2286 & 33 & 10515 & 48.555529 & -120.590182 \\
\hline 245401 & 3090 & & $0.017 \pm 0.003$ & 1958 & 44 & 2198 & 16 & 13034 & 48.587822 & -120.698106 \\
\hline 245402 & 3079 & & $0.063 \pm 0.006$ & 1958 & 31 & 2119 & 36 & 15056 & 48.589477 & -120.700739 \\
\hline 245403 & 3080 & & $0.069 \pm 0.007$ & 1958 & 22 & 2090 & 5 & 11787 & 48.594116 & -120.708858 \\
\hline 245405 & 3081 & & $0.043 \pm 0.005$ & 1958 & 36 & 2079 & 334 & 12938 & 48.606315 & -120.733547 \\
\hline 245501 & 2050 & & $0.027 \pm 0.004$ & 1958 & 21 & 2380 & 72 & 16811 & 48.727505 & -120.568529 \\
\hline
\end{tabular}




\begin{tabular}{|c|c|c|c|c|c|c|c|c|c|c|}
\hline BasinID & RECNO (s) & Glacier Name & Area $\left(\mathrm{km}^{2}\right)$ & Year & $\mathrm{S}_{\text {mean }}$ & $Z_{\text {mean }}$ & $A_{\text {mean }}$ & $I_{\text {mean }}$ & Latitude & Longitude \\
\hline 245503 & 2451 & & $0.035 \pm 0.005$ & 1968 & 35 & 2365 & 32 & 11530 & 48.826194 & -120.526267 \\
\hline 245504 & 2452 & & $0.022 \pm 0.004$ & 1968 & 36 & 2463 & 42 & 6941 & 48.826936 & -120.530826 \\
\hline 245505 & 2453 & & $0.017 \pm 0.003$ & 1968 & 30 & 2411 & 68 & 13126 & 48.828932 & -120.531755 \\
\hline 245506 & 2447 & & $0.002 \pm 0.001$ & 1968 & 27 & 2388 & 106 & 20536 & 48.830222 & -120.531431 \\
\hline 245507 & 2476 & & $0.021 \pm 0.004$ & 1968 & 27 & 2277 & 38 & 15438 & 48.835465 & -120.528301 \\
\hline 245508 & 2449 & & $0.067 \pm 0.007$ & 1968 & 35 & 2311 & 28 & 11575 & 48.866375 & -120.527610 \\
\hline 245509 & 2450 & & $0.044 \pm 0.005$ & 1968 & 34 & 2284 & 36 & 10895 & 48.869056 & -120.532636 \\
\hline 246301 & 2467 & & $0.015 \pm 0.003$ & 1968 & 32 & 2328 & 351 & 8880 & 48.854324 & -120.542841 \\
\hline 246302 & 2456 & & $0.046 \pm 0.006$ & 1968 & 37 & 2382 & 355 & 8512 & 48.831123 & -120.538882 \\
\hline 246303 & 2455 & & $0.044 \pm 0.005$ & 1968 & 31 & 2278 & 5 & 10822 & 48.831590 & -120.548602 \\
\hline 246304 & 2462 & & $0.017 \pm 0.003$ & 1968 & 39 & 2295 & 14 & 10594 & 48.833157 & -120.551911 \\
\hline 246305 & 2468 & & $0.036 \pm 0.005$ & 1968 & 33 & 2256 & 331 & 10627 & 48.834386 & -120.556347 \\
\hline 246306 & 2454 & & $0.026 \pm 0.004$ & 1968 & 29 & 2222 & 31 & 13683 & 48.830022 & -120.571202 \\
\hline 246307 & 2448 & & $0.050 \pm 0.006$ & 1968 & 37 & 2302 & 12 & 11923 & 48.833366 & -120.576150 \\
\hline 246501 & 2369 & & $0.059 \pm 0.006$ & 1968 & 32 & 2071 & 35 & 13389 & 48.981290 & -120.854641 \\
\hline 246502 & 2371 & & $0.060 \pm 0.006$ & 1968 & 23 & 2036 & 42 & 15110 & 48.984269 & -120.857956 \\
\hline 2211011 & 2501 & Squak Glacier & $2.128 \pm 0.038$ & 1975 & 22 & 2223 & 155 & 25071 & 48.751062 & -121.813586 \\
\hline 22110301 & 2502 & Boulder Glacier & $2.439 \pm 0.038$ & 1975 & 9999 & 9999 & 9999 & 9969 & 48.776969 & -121.790165 \\
\hline
\end{tabular}




\section{Appendix B - Temporal Glacier Inventories}

Each temporal inventory is compiled below for each individual glacier. The BasinID matches the 24K subset, and features with 'NoData' were not used in the analysis.

\begin{tabular}{|c|c|c|c|c|c|c|c|}
\hline BasinID & $\begin{array}{c}1900 \text { Area } \\
\left(\mathrm{km}^{2}\right)\end{array}$ & BasinID & $\begin{array}{c}1900 \text { Area } \\
\left(\mathrm{km}^{2}\right)\end{array}$ & BasinID & $\begin{array}{c}1900 \text { Area } \\
\left(\mathrm{km}^{2}\right)\end{array}$ & BasinID & $\begin{array}{c}1900 \text { Area } \\
\left(\mathrm{km}^{2}\right)\end{array}$ \\
\hline 211401 & $0.222 \pm 0.012$ & 221303 & $0.849 \pm 0.024$ & 222303 & $0.219 \pm 0.012$ & 223601 & $0.158 \pm 0.010$ \\
\hline 211402 & $0.452 \pm 0.017$ & 221304 & $0.593 \pm 0.020$ & 222304 & $0.079 \pm 0.007$ & 223602 & $0.332 \pm 0.015$ \\
\hline 211403 & $0.226 \pm 0.012$ & 221401 & $0.647 \pm 0.021$ & 222305 & $0.476 \pm 0.018$ & 223603 & $0.466 \pm 0.018$ \\
\hline 211404 & $0.042 \pm 0.005$ & 221402 & $0.704 \pm 0.022$ & 222306 & $0.369 \pm 0.016$ & 223604 & $0.433 \pm 0.017$ \\
\hline 211405 & $0.166 \pm 0.011$ & 221403 & $0.795 \pm 0.023$ & 222307 & $0.144 \pm 0.010$ & 223605 & $0.096 \pm 0.008$ \\
\hline 211406 & $0.063 \pm 0.006$ & 221404 & $0.560 \pm 0.019$ & 222308 & $0.367 \pm 0.016$ & 223606 & $1.183 \pm 0.028$ \\
\hline 211407 & $0.048 \pm 0.006$ & 221406 & $0.326 \pm 0.015$ & 222309 & $0.420 \pm 0.017$ & 223607 & $0.311 \pm 0.014$ \\
\hline 211408 & $0.383 \pm 0.016$ & 221501 & $0.641 \pm 0.021$ & 222311 & $0.213 \pm 0.012$ & 223609 & $0.283 \pm 0.014$ \\
\hline 211409 & $0.089 \pm 0.008$ & 221502 & $0.097 \pm 0.008$ & 222312 & $0.284 \pm 0.014$ & 223610 & $0.974 \pm 0.026$ \\
\hline 211410 & $0.053 \pm 0.006$ & 221503 & $0.297 \pm 0.014$ & 222313 & $0.405 \pm 0.016$ & 223611 & $0.546 \pm 0.019$ \\
\hline 211411 & $0.072 \pm 0.007$ & 221504 & $0.181 \pm 0.011$ & 222314 & $1.249 \pm 0.029$ & 223701 & $0.244 \pm 0.013$ \\
\hline 211412 & $0.275 \pm 0.014$ & 221601 & $0.107 \pm 0.008$ & 222315 & $0.355 \pm 0.015$ & 223702 & $1.137 \pm 0.028$ \\
\hline 211413 & $0.123 \pm 0.009$ & 221602 & $0.122 \pm 0.009$ & 222316 & $0.815 \pm 0.023$ & 223703 & $0.268 \pm 0.013$ \\
\hline 211414 & $0.029 \pm 0.004$ & 221603 & $1.256 \pm 0.029$ & 222401 & $0.446 \pm 0.017$ & 224701 & $0.876 \pm 0.024$ \\
\hline 211415 & $0.102 \pm 0.008$ & 221604 & $0.579 \pm 0.020$ & 222402 & $0.490 \pm 0.018$ & 224702 & $0.311 \pm 0.014$ \\
\hline 211501 & $0.153 \pm 0.010$ & 221605 & NoData & 222403 & $0.396 \pm 0.016$ & 224703 & $1.085 \pm 0.027$ \\
\hline 211502 & $0.189 \pm 0.011$ & 221606 & $1.168 \pm 0.028$ & 222404 & $0.245 \pm 0.013$ & 224704 & $0.376 \pm 0.016$ \\
\hline 211503 & $0.050 \pm 0.006$ & 221701 & $0.623 \pm 0.020$ & 222405 & $0.344 \pm 0.015$ & 224705 & $0.157 \pm 0.010$ \\
\hline 211504 & $0.296 \pm 0.014$ & 221702 & $0.609 \pm 0.020$ & 222406 & $0.356 \pm 0.015$ & 224706 & $1.021 \pm 0.026$ \\
\hline 211505 & $0.220 \pm 0.012$ & 221703 & NoData & 222407 & $0.463 \pm 0.018$ & 224707 & $0.107 \pm 0.008$ \\
\hline 211506 & $3.584 \pm 0.049$ & 221704 & $0.883 \pm 0.024$ & 222408 & $0.699 \pm 0.022$ & 224708 & $0.327 \pm 0.015$ \\
\hline 211507 & $1.698 \pm 0.034$ & 221705 & $0.209 \pm 0.012$ & 222501 & $1.218 \pm 0.029$ & 224709 & $0.118 \pm 0.009$ \\
\hline 211508 & $0.725 \pm 0.022$ & 221706 & $0.356 \pm 0.015$ & 222502 & $0.691 \pm 0.022$ & 224710 & $0.138 \pm 0.010$ \\
\hline 211509 & $0.342 \pm 0.015$ & 221707 & $0.092 \pm 0.008$ & 222601 & $0.183 \pm 0.011$ & 224711 & $0.170 \pm 0.011$ \\
\hline 211510 & $0.302 \pm 0.014$ & 221708 & NoData & 222602 & $0.364 \pm 0.016$ & 224713 & $0.138 \pm 0.010$ \\
\hline 211601 & NoData & 221709 & $0.235 \pm 0.013$ & 222603 & $0.877 \pm 0.024$ & 224714 & $0.325 \pm 0.015$ \\
\hline 211602 & $0.062 \pm 0.006$ & 221710 & $0.199 \pm 0.012$ & 222701 & $0.362 \pm 0.016$ & 224801 & $0.558 \pm 0.019$ \\
\hline 211603 & $0.723 \pm 0.022$ & 221711 & $0.134 \pm 0.009$ & 223101 & $1.427 \pm 0.031$ & 225101 & $0.144 \pm 0.010$ \\
\hline 211604 & $0.342 \pm 0.015$ & 221712 & $0.050 \pm 0.006$ & 223102 & $1.591 \pm 0.033$ & 225102 & $0.114 \pm 0.009$ \\
\hline 211701 & $0.082 \pm 0.007$ & 221713 & NoData & 223103 & $0.299 \pm 0.014$ & 225103 & $0.344 \pm 0.015$ \\
\hline 211702 & $0.059 \pm 0.006$ & 221714 & $0.588 \pm 0.020$ & 223104 & $0.204 \pm 0.012$ & 225104 & $0.126 \pm 0.009$ \\
\hline 211801 & $0.506 \pm 0.018$ & 221801 & $0.287 \pm 0.014$ & 223105 & $0.974 \pm 0.026$ & 225105 & $0.625 \pm 0.020$ \\
\hline 211802 & $0.332 \pm 0.015$ & 221802 & $0.118 \pm 0.009$ & 223201 & $0.132 \pm 0.009$ & 225106 & $0.379 \pm 0.016$ \\
\hline 211803 & $0.224 \pm 0.012$ & 221803 & $0.246 \pm 0.013$ & 223202 & $0.902 \pm 0.025$ & 225107 & $0.692 \pm 0.022$ \\
\hline 211804 & $0.972 \pm 0.026$ & 221804 & $0.556 \pm 0.019$ & 223203 & $0.594 \pm 0.020$ & 225108 & $1.000 \pm 0.026$ \\
\hline 211901 & $0.188 \pm 0.011$ & 221805 & $0.580 \pm 0.020$ & 223204 & $0.611 \pm 0.020$ & 225109 & $1.587 \pm 0.033$ \\
\hline 211902 & $0.100 \pm 0.008$ & 221806 & $0.321 \pm 0.015$ & 223205 & $3.597 \pm 0.049$ & 225110 & $0.441 \pm 0.017$ \\
\hline 212301 & $0.356 \pm 0.015$ & 221807 & $0.141 \pm 0.010$ & 223206 & $0.714 \pm 0.022$ & 225111 & $0.490 \pm 0.018$ \\
\hline 212302 & $1.076 \pm 0.027$ & 221808 & $0.364 \pm 0.016$ & 223207 & $1.471 \pm 0.031$ & 225112 & $0.251 \pm 0.013$ \\
\hline 212303 & $1.286 \pm 0.029$ & 221809 & $1.510 \pm 0.032$ & 223301 & $1.754 \pm 0.034$ & 225113 & $0.696 \pm 0.022$ \\
\hline 212304 & $5.671 \pm 0.062$ & 221901 & $1.220 \pm 0.029$ & 223302 & $5.209 \pm 0.059$ & 22 & $1.058 \pm 0.027$ \\
\hline 212305 & $0.611 \pm 0.020$ & 221902 & $0.164 \pm 0.010$ & 223303 & $0.463 \pm 0.018$ & 225115 & $1.713 \pm 0.034$ \\
\hline 212306 & $3.275 \pm 0.047$ & 221903 & $0.306 \pm 0.014$ & 223304 & $0.564 \pm 0.019$ & 225201 & $0.281 \pm 0.014$ \\
\hline 212307 & $0.182 \pm 0.011$ & 222101 & NoData & 223305 & $0.176 \pm 0.011$ & 225202 & $0.171 \pm 0.011$ \\
\hline 212401 & $1.319 \pm 0.030$ & 222102 & $1.271 \pm 0.029$ & 223401 & $0.303 \pm 0.014$ & 225203 & $1.019 \pm 0.026$ \\
\hline 212402 & $1.516 \pm 0.032$ & 222103 & $0.516 \pm 0.019$ & 223402 & $0.123 \pm 0.009$ & 225204 & $0.566 \pm 0.019$ \\
\hline 212702 & $5.095 \pm 0.058$ & 222202 & $0.211 \pm 0.012$ & 223403 & $0.262 \pm 0.013$ & 225205 & $9.632 \pm 0.080$ \\
\hline 212703 & $5.447 \pm 0.060$ & 222204 & $0.136 \pm 0.010$ & 223404 & $0.230 \pm 0.012$ & 225301 & $0.478 \pm 0.018$ \\
\hline 213105 & $6.509 \pm 0.066$ & 222205 & $1.589 \pm 0.033$ & 223405 & $0.359 \pm 0.015$ & 225302 & $0.850 \pm 0.024$ \\
\hline 221101 & $4.191 \pm 0.053$ & 222206 & $1.483 \pm 0.032$ & 223406 & $0.164 \pm 0.010$ & 225303 & $3.956 \pm 0.051$ \\
\hline 221103 & $5.479 \pm 0.061$ & 222207 & $0.436 \pm 0.017$ & 223407 & $0.663 \pm 0.021$ & 225304 & $0.824 \pm 0.023$ \\
\hline 221204 & $1.480 \pm 0.031$ & 222208 & $0.787 \pm 0.023$ & 223408 & $0.537 \pm 0.019$ & 225305 & $0.515 \pm 0.019$ \\
\hline 221205 & $0.532 \pm 0.019$ & 222209 & $0.175 \pm 0.011$ & 223501 & $0.165 \pm 0.011$ & 225306 & $6.401 \pm 0.065$ \\
\hline 221206 & $0.383 \pm 0.016$ & 222210 & $0.083 \pm 0.007$ & 223502 & $0.705 \pm 0.022$ & 225307 & $0.695 \pm 0.022$ \\
\hline 221301 & $5.571 \pm 0.061$ & 222301 & $0.921 \pm 0.025$ & 223503 & $0.362 \pm 0.016$ & 225308 & $0.371 \pm 0.016$ \\
\hline 221302 & $3.576 \pm 0.049$ & 222302 & $0.610 \pm 0.020$ & 223504 & $0.548 \pm 0.019$ & 225309 & $3.685 \pm 0.050$ \\
\hline
\end{tabular}




\begin{tabular}{|c|c|c|c|c|c|c|c|c|c|c|}
\hline BasinID & $\begin{array}{c}1900 \text { Area } \\
\left(\mathrm{km}^{2}\right)\end{array}$ & BasinID & \multicolumn{2}{|c|}{$\begin{array}{c}1900 \text { Area } \\
\left(\mathrm{km}^{2}\right)\end{array}$} & BasinID & \multicolumn{2}{|c|}{1900 Area } & BasinID & \multicolumn{2}{|c|}{1900 Area } \\
\hline 225310 & $2.772 \pm 0.043$ & 226102 & \multicolumn{2}{|c|}{$0.504 \pm 0.018$} & 244602 & \multicolumn{2}{|c|}{$0.607 \pm 0.020$} & 244705 & \multicolumn{2}{|c|}{$0.135 \pm 0.010$} \\
\hline 225401 & $0.388 \pm 0.016$ & 226103 & \multicolumn{2}{|c|}{$2.248 \pm 0.039$} & 244603 & \multicolumn{2}{|c|}{$0.579 \pm 0.020$} & 244706 & \multicolumn{2}{|c|}{$0.157 \pm 0.010$} \\
\hline 225402 & $0.698 \pm 0.022$ & 226104 & \multicolumn{2}{|c|}{$0.261 \pm 0.013$} & 244604 & \multicolumn{2}{|c|}{$0.183 \pm 0.011$} & 244707 & 0.147 & 0.010 \\
\hline 225403 & $0.266 \pm 0.013$ & 226105 & $1.101 \pm 0$ & .027 & 244605 & $0.047 \pm$ & .006 & 244708 & 1.836 & 0.035 \\
\hline 225501 & $1.747 \pm 0.034$ & 226106 & $0.707 \pm 0$ & .022 & 244606 & $0.051 \pm$ & .006 & 244709 & 0.277 & 0.014 \\
\hline 225502 & NoData & 226107 & $0.489 \pm 0$ & .018 & 244607 & $0.279 \pm$ & .014 & 244710 & 0.624 & 0.020 \\
\hline 225503 & $0.070 \pm 0.007$ & 226108 & $0.672 \pm 0$ & .021 & 244608 & $0.228 \pm$ & .012 & 244711 & 0.092 & 0.008 \\
\hline 225504 & $0.967 \pm 0.025$ & 226110 & $0.655 \pm 0$ & .021 & 244609 & $0.522 \pm$ & .019 & 244712 & 0.486 & 0.018 \\
\hline 225505 & $0.393 \pm 0.016$ & 226201 & $0.515 \pm 0$ & .019 & 244610 & $0.553 \pm$ & 019 & 244713 & 0.143 & 0.010 \\
\hline 225506 & $0.440 \pm 0.017$ & 226202 & $0.456 \pm 0$ & .017 & 244611 & $1.121 \pm$ & .027 & 244714 & 0.216 & 0.012 \\
\hline 225507 & $0.145 \pm 0.010$ & 226203 & $4.199 \pm 0$ & .053 & 244612 & $0.090 \pm$ & .008 & 244801 & 0.070 & 0.007 \\
\hline 225508 & $0.295 \pm 0.014$ & 226205 & $0.201 \pm 0$ & .012 & 244613 & $0.211 \pm$ & .012 & 244802 & 0.214 & 0.012 \\
\hline 225509 & $7.189 \pm 0.069$ & 226206 & $0.341 \pm 0$ & .015 & 244614 & $0.123 \pm$ & .009 & 244803 & 0.306 & 0.014 \\
\hline 225510 & $0.461 \pm 0.018$ & 226207 & $0.976 \pm 0$ & .026 & 244616 & $0.072 \pm$ & .007 & 244805 & 0.399 & 0.016 \\
\hline 225511 & $0.243 \pm 0.013$ & 226208 & $0.976 \pm 0$ & .026 & 244617 & $0.087 \pm$ & .008 & 244806 & 0.184 & 0.011 \\
\hline 225512 & $1.500 \pm 0.032$ & 226209 & $1.990 \pm 0$ & .037 & 244618 & $0.048 \pm$ & .006 & 244807 & 0.391 & .016 \\
\hline 225513 & $0.302 \pm 0.014$ & 226210 & $0.269 \pm 0$ & .013 & 244620 & $0.783 \pm$ & .023 & 244808 & 0.444 & 017 \\
\hline 225514 & $0.575 \pm 0.020$ & 226211 & $0.155 \pm 0$ & .010 & 244621 & $0.749 \pm$ & .022 & 244809 & 0.179 & 011 \\
\hline 225601 & $0.427 \pm 0.017$ & 226212 & $0.392 \pm 0$ & .016 & 244622 & $0.700 \pm$ & .022 & 244810 & 0.398 & .016 \\
\hline 225602 & $4.846 \pm 0.057$ & 226213 & $0.580 \pm 0$ & .020 & 244623 & $0.148 \pm$ & .010 & 244811 & 0.397 & 0.016 \\
\hline 225701 & $1.609 \pm 0.033$ & 226406 & $3.226 \pm 0$ & .046 & 244702 & $0.124 \pm$ & .009 & 224712 & 0.360 & 016 \\
\hline 225702 & $0.578 \pm 0.020$ & 224703 & $1.085 \pm 0$ & .027 & 244703 & $1.173 \pm$ & .028 & & & \\
\hline 226101 & $1.041 \pm 0.026$ & 244601 & $0.345 \pm 0$ & .015 & 244704 & $0.388 \pm$ & .016 & & & \\
\hline BasinID & $\begin{array}{c}1958 \text { Area } \\
\left(\mathrm{km}^{2}\right)\end{array}$ & $\begin{array}{c}\begin{array}{c}\text { Source } \\
\text { Year }\end{array} \\
\end{array}$ & BasinID & & $\overline{e a}$ & $\begin{array}{c}\text { Source } \\
\text { Year }\end{array}$ & BasinID & 1958 & $\begin{array}{l}\text { Area } \\
\left.{ }^{2}\right)\end{array}$ & $\begin{array}{c}\text { Source } \\
\text { Year }\end{array}$ \\
\hline 211301 & NoData & 1958 & 224709 & 0.03 & 0.005 & 1958 & 225402 & $0.295 \pm$ & .014 & 1958 \\
\hline 211502 & $0.072 \pm 0.007$ & 1958 & 224710 & 0.05 & 0.006 & 1958 & 225403 & $0.152 \pm$ & 0.010 & 1958 \\
\hline 211602 & $0.058 \pm 0.006$ & 1958 & 224711 & 0.06 & 0.006 & 1958 & 225501 & $1.208 \pm$ & 0.028 & 1958 \\
\hline 221806 & $0.140 \pm 0.010$ & 1958 & 224713 & 0.04 & 0.006 & 1959 & 225502 & $0.067 \pm$ & 0.007 & 1958 \\
\hline 222203 & $0.103 \pm 0.008$ & 1958 & 224714 & $\mathrm{NoD}$ & & 1959 & 225503 & $0.054 \pm$ & .054 & 1958 \\
\hline 222210 & $0.082 \pm 0.007$ & 1958 & 224801 & 0.07 & 0.007 & 1958 & 225504 & $0.404 \pm$ & .016 & 1958 \\
\hline 222401 & $0.355 \pm 0.015$ & 1958 & 225101 & 0.07 & 0.007 & 1958 & 225505 & $0.195 \pm$ & .011 & 1958 \\
\hline 222402 & $0.186 \pm 0.011$ & 1958 & 225102 & 0.04 & 0.006 & 1958 & 225506 & $0.178 \pm$ & .011 & 1958 \\
\hline 222403 & NoData & 1958 & 225103 & 0.02 & 0.004 & 1958 & 225507 & $0.053 \pm$ & .006 & 1958 \\
\hline 222501 & $0.462 \pm 0.018$ & 1958 & 225104 & 0.02 & 0.004 & 1958 & 225508 & $0.098 \pm$ & .008 & 1958 \\
\hline 222502 & $0.181 \pm 0.011$ & 1958 & 225105 & 0.16 & 0.011 & 1958 & 225509 & $4.971 \pm$ & 0.058 & 1958 \\
\hline 222601 & $0.077 \pm 0.077$ & 1958 & 225106 & 0.10 & 0.008 & 1958 & 225510 & $0.299 \pm$ & 0.014 & 1958 \\
\hline 222602 & $0.091 \pm 0.008$ & 1958 & 225107 & 0.18 & 0.011 & 1958 & 225511 & $0.099 \pm$ & .008 & 1958 \\
\hline 223608 & $0.409 \pm 0.017$ & 1958 & 225108 & 0.45 & 0.018 & 1958 & 225512 & $0.874 \pm$ & .024 & 1958 \\
\hline 223609 & $0.122 \pm 0.009$ & 1958 & 225109 & 0.96 & 0.025 & 1958 & 225513 & $0.124 \pm$ & .009 & 1958 \\
\hline 223610 & $0.805 \pm 0.023$ & 1958 & 225110 & 0.19 & 0.011 & 1958 & 225514 & $0.216 \pm$ & .012 & 1958 \\
\hline 224401 & $0.161 \pm 0.010$ & 1959 & 225111 & 0.18 & 0.011 & 1958 & 225601 & $0.184 \pm$ & .185 & 1958 \\
\hline 224402 & $0.363 \pm 0.016$ & 1959 & 225112 & 0.06 & 0.007 & 1958 & 225602 & $3.898 \pm$ & .051 & 1958 \\
\hline 224403 & NoData & 1959 & 225113 & 0.20 & 0.012 & 1958 & 225701 & $1.039 \pm$ & 0.026 & 1958 \\
\hline 224601 & NoData & 1958 & 225114 & 0.72 & 0.022 & 1958 & 225702 & $0.199 \pm$ & .012 & 1958 \\
\hline 224602 & $0.172 \pm 0.011$ & 1958 & 225115 & 0.94 & 0.025 & 1958 & 226101 & $0.056 \pm$ & .006 & 1958 \\
\hline 224603 & $0.081 \pm 0.007$ & 1958 & 225201 & 0.08 & 0.008 & 1958 & 226102 & $0.071 \pm$ & .007 & 1958 \\
\hline 224604 & $0.064 \pm 0.007$ & 1958 & 225202 & 0.05 & 0.006 & 1958 & 226103 & $0.731 \pm$ & 0.022 & 1958 \\
\hline 224605 & $0.056 \pm 0.006$ & 1958 & 225203 & 0.22 & 0.012 & 1958 & 226104 & NoData & & 1958 \\
\hline 224606 & $0.077 \pm 0.007$ & 1958 & 225204 & 0.16 & 0.011 & 1958 & 226105 & $0.411 \pm$ & .017 & 1958 \\
\hline 224607 & $0.044 \pm 0.005$ & 1958 & 225205 & 6.75 & 0.067 & 1958 & 226106 & $0.201 \pm$ & .012 & 1958 \\
\hline 224608 & $0.076 \pm 0.077$ & 1958 & 225301 & NoD & & 1958 & 226107 & $0.105 \pm$ & 0.008 & 1958 \\
\hline 224609 & $0.060 \pm 0.006$ & 1958 & 225302 & $\mathrm{NoD}$ & & 1958 & 226108 & $0.300 \pm$ & 0.014 & 1958 \\
\hline 224610 & NoData & 1959 & 225303 & 1.72 & 0.034 & 1958 & 226109 & $0.267 \pm$ & 0.013 & 1958 \\
\hline 224701 & $0.540 \pm 0.019$ & 1958 & 225304 & 0.15 & 0.010 & 1958 & 226201 & $0.086 \pm$ & .008 & 1958 \\
\hline 224702 & $0.214 \pm 0.012$ & 1958 & 225305 & 0.10 & 0.008 & 1958 & 226202 & $0.082 \pm$ & .007 & 1958 \\
\hline 224703 & $0.810 \pm 0.023$ & 1958 & 225306 & 4.47 & 0.055 & 1958 & 226203 & $2.025 \pm$ & 0.037 & 1958 \\
\hline 224704 & $0.141 \pm 0.010$ & 1958 & 225307 & 0.54 & 0.019 & 1958 & 226205 & $0.061 \pm$ & .006 & 1958 \\
\hline 224705 & NoData & 1958 & 225308 & 0.11 & 0.009 & 1958 & 226206 & $0.070 \pm$ & .007 & 1958 \\
\hline 224706 & $0.831 \pm 0.024$ & 1958 & 225309 & 2.20 & 0.038 & 1958 & 226207 & $0.322 \pm$ & 0.015 & 1958 \\
\hline 224707 & $0.059 \pm 0.006$ & 1958 & 225310 & 1.75 & 0.034 & 1958 & 226208 & $0.147 \pm$ & .147 & 1958 \\
\hline 224708 & $0.123 \pm 0.009$ & 1958 & 225401 & 0.22 & 0.012 & 1958 & 226209 & NoData & & 1958 \\
\hline
\end{tabular}




\begin{tabular}{|c|c|c|c|c|c|c|c|c|}
\hline BasinID & $\begin{array}{c}1958 \text { Area } \\
\left(\mathrm{km}^{2}\right)\end{array}$ & $\begin{array}{c}\text { Source } \\
\text { Year }\end{array}$ & BasinID & $\begin{array}{c}1958 \text { Area } \\
\left(\mathrm{km}^{2}\right)\end{array}$ & $\begin{array}{c}\text { Source } \\
\text { Year }\end{array}$ & BasinID & $\begin{array}{c}1958 \text { Area } \\
\left(\mathrm{km}^{2}\right)\end{array}$ & $\begin{array}{c}\text { Source } \\
\text { Year }\end{array}$ \\
\hline 226210 & $0.055 \pm 0.006$ & 1958 & 228503 & NoData & 1958 & 244410 & $0.049 \pm 0.006$ & 1958 \\
\hline 226211 & $0.060 \pm 0.006$ & 1958 & 228504 & $0.029 \pm 0.004$ & 1958 & 244411 & $0.055 \pm 0.006$ & 1958 \\
\hline 226212 & $0.126 \pm 0.009$ & 1958 & 228505 & $0.108 \pm 0.009$ & 1958 & 244412 & $0.050 \pm 0.006$ & 1958 \\
\hline 226213 & $0.270 \pm 0.013$ & 1958 & 228603 & $0.156 \pm 0.010$ & 1958 & 244413 & $0.043 \pm 0.005$ & 1958 \\
\hline 226301 & $0.042 \pm 0.005$ & 1958 & 228604 & $0.265 \pm 0.013$ & 1958 & 244414 & $0.077 \pm 0.007$ & 1958 \\
\hline 226302 & $0.077 \pm 0.007$ & 1958 & 233201 & $0.043 \pm 0.005$ & 1958 & 244415 & $0.117 \pm 0.009$ & 1958 \\
\hline 226303 & $0.988 \pm 0.026$ & 1958 & 233202 & $0.037 \pm 0.005$ & 1958 & 244416 & $0.116 \pm 0.009$ & 1958 \\
\hline 226304 & $0.287 \pm 0.014$ & 1958 & 233203 & NoData & 1958 & 244417 & $0.242 \pm 0.013$ & 1958 \\
\hline 226305 & $0.074 \pm 0.007$ & 1958 & 233204 & $0.803 \pm 0.023$ & 1958 & 244501 & $0.027 \pm 0.004$ & 1958 \\
\hline 226306 & $0.059 \pm 0.006$ & 1958 & 233205 & $0.087 \pm 0.008$ & 1958 & 244502 & $0.030 \pm 0.005$ & 1958 \\
\hline 226307 & $0.074 \pm 0.007$ & 1958 & 233206 & $0.071 \pm 0.007$ & 1958 & 244503 & $0.165 \pm 0.011$ & 1958 \\
\hline 226308 & $0.070 \pm 0.007$ & 1958 & 233207 & NoData & 1958 & 244504 & $1.581 \pm 0.033$ & 1958 \\
\hline 226401 & $0.054 \pm 0.006$ & 1958 & 233208 & $0.122 \pm 0.009$ & 1958 & 244505 & $0.331 \pm 0.015$ & 1958 \\
\hline 226402 & $0.048 \pm 0.006$ & 1958 & 233209 & $0.053 \pm 0.006$ & 1958 & 244506 & $0.031 \pm 0.005$ & 1958 \\
\hline 226403 & $0.031 \pm 0.005$ & 1958 & 233401 & $0.116 \pm 0.009$ & 1958 & 244507 & $0.141 \pm 0.010$ & 1958 \\
\hline 226404 & $0.214 \pm 0.012$ & 1958 & 233402 & $0.878 \pm 0.024$ & 1958 & 244508 & $0.145 \pm 0.010$ & 1958 \\
\hline 226405 & $0.063 \pm 0.007$ & 1958 & 233403 & $0.133 \pm 0.009$ & 1958 & 244509 & $0.023 \pm 0.004$ & 1958 \\
\hline 226406 & $2.924 \pm 0.044$ & 1958 & 233404 & $0.291 \pm 0.014$ & 1958 & 244510 & NoData & 1958 \\
\hline 226407 & $0.492 \pm 0.018$ & 1958 & 233405 & $0.905 \pm 0.025$ & 1958 & 244511 & $0.245 \pm 0.013$ & 1958 \\
\hline 226408 & $0.549 \pm 0.019$ & 1958 & 233406 & $0.141 \pm 0.010$ & 1958 & 244512 & $0.314 \pm 0.015$ & 1958 \\
\hline 226410 & $0.035 \pm 0.005$ & 1958 & 233407 & $1.259 \pm 0.029$ & 1958 & 244513 & $0.036 \pm 0.036$ & 1958 \\
\hline 226411 & $0.089 \pm 0.008$ & 1958 & 233408 & NoData & 1958 & 244514 & $0.056 \pm 0.006$ & 1958 \\
\hline 226412 & $0.062 \pm 0.006$ & 1958 & 233409 & $0.087 \pm 0.008$ & 1958 & 244515 & $0.102 \pm 0.102$ & 1958 \\
\hline 226413 & $0.047 \pm 0.006$ & 1958 & 234203 & $0.142 \pm 0.010$ & 1958 & 244516 & $0.099 \pm 0.008$ & 1958 \\
\hline 226501 & $0.193 \pm 0.011$ & 1958 & 234204 & $0.376 \pm 0.016$ & 1958 & 244517 & $0.046 \pm 0.006$ & 1958 \\
\hline 226502 & $0.819 \pm 0.023$ & 1958 & 241302 & $0.127 \pm 0.009$ & 1957 & 244518 & $0.019 \pm 0.004$ & 1958 \\
\hline 226503 & $0.072 \pm 0.007$ & 1958 & 241303 & $0.163 \pm 0.010$ & 1957 & 244519 & $0.024 \pm 0.004$ & 1958 \\
\hline 226504 & NoData & 1958 & 241304 & NoData & 1957 & 244601 & $0.093 \pm 0.008$ & 1958 \\
\hline 226505 & $0.116 \pm 0.009$ & 1958 & 241305 & $0.460 \pm 0.018$ & 1958 & 244602 & $0.278 \pm 0.014$ & 1958 \\
\hline 226601 & $0.047 \pm 0.006$ & 1958 & 241306 & $0.158 \pm 0.010$ & 1958 & 244603 & $0.129 \pm 0.009$ & 1958 \\
\hline 227103 & $0.086 \pm 0.086$ & 1958 & 241307 & $0.214 \pm 0.012$ & 1958 & 244604 & $0.075 \pm 0.007$ & 1958 \\
\hline 227104 & NoData & 1958 & 241501 & $0.192 \pm 0.011$ & 1958 & 244605 & $0.024 \pm 0.004$ & 1958 \\
\hline 227105 & NoData & 1958 & 241502 & $0.049 \pm 0.006$ & 1958 & 244606 & $0.032 \pm 0.005$ & 1958 \\
\hline 227106 & $0.033 \pm 0.005$ & 1958 & 241503 & $0.038 \pm 0.005$ & 1958 & 244607 & $0.160 \pm 0.010$ & 1958 \\
\hline 227107 & NoData & 1958 & 241504 & $0.435 \pm 0.017$ & 1958 & 244608 & $0.060 \pm 0.006$ & 1958 \\
\hline 227201 & $0.028 \pm 0.004$ & 1958 & 242201 & $0.050 \pm 0.006$ & 1957 & 244609 & $0.293 \pm 0.014$ & 1958 \\
\hline 227202 & $0.080 \pm 0.007$ & 1958 & 242202 & $0.111 \pm 0.009$ & 1957 & 244610 & $0.155 \pm 0.010$ & 1958 \\
\hline 227203 & $0.254 \pm 0.013$ & 1958 & 242203 & $0.118 \pm 0.009$ & 1957 & 244611 & NoData & 1958 \\
\hline 227204 & $0.743 \pm 0.022$ & 1958 & 242204 & $0.058 \pm 0.006$ & 1957 & 244612 & NoData & 1958 \\
\hline 227205 & $0.080 \pm 0.007$ & 1958 & 242205 & $0.047 \pm 0.006$ & 1957 & 244613 & $0.134 \pm 0.009$ & 1958 \\
\hline 227206 & $0.025 \pm 0.004$ & 1958 & 242206 & $0.036 \pm 0.005$ & 1957 & 244614 & $0.078 \pm 0.007$ & 1958 \\
\hline 227207 & $0.077 \pm 0.007$ & 1958 & 242207 & NoData & 1957 & 244615 & $0.038 \pm 0.005$ & 1958 \\
\hline 227208 & $0.040 \pm 0.005$ & 1958 & 242208 & $0.066 \pm 0.007$ & 1957 & 244616 & $0.053 \pm 0.006$ & 1958 \\
\hline 227209 & $0.087 \pm 0.008$ & 1958 & 242209 & $0.114 \pm 0.009$ & 1957 & 244617 & $0.052 \pm 0.006$ & 1958 \\
\hline 227210 & $0.928 \pm 0.025$ & 1958 & 242210 & $0.021 \pm 0.004$ & 1957 & 244618 & $0.021 \pm 0.004$ & 1958 \\
\hline 227211 & $0.105 \pm 0.008$ & 1958 & 242211 & $0.141 \pm 0.010$ & 1957 & 244619 & NoData & 1958 \\
\hline 227212 & $0.031 \pm 0.005$ & 1958 & 242212 & NoData & 1957 & 244620 & NoData & 1958 \\
\hline 227301 & $0.156 \pm 0.010$ & 1958 & 242213 & $0.093 \pm 0.008$ & 1957 & 244621 & $0.293 \pm 0.014$ & 1958 \\
\hline 227302 & $0.103 \pm 0.008$ & 1958 & 242214 & $0.012 \pm 0.003$ & 1957 & 244622 & $0.275 \pm 0.014$ & 1958 \\
\hline 227303 & $0.040 \pm 0.005$ & 1958 & 244223 & NoData & 1958 & 244623 & $0.082 \pm 0.007$ & 1958 \\
\hline 227304 & $0.115 \pm 0.009$ & 1958 & 244301 & $0.005 \pm 0.002$ & 1958 & 244624 & $0.019 \pm 0.004$ & 1958 \\
\hline 227305 & $0.033 \pm 0.005$ & 1958 & 244302 & $0.678 \pm 0.021$ & 1958 & 244625 & $0.013 \pm 0.003$ & 1958 \\
\hline 227306 & $1.062 \pm 0.027$ & 1958 & 244306 & $0.063 \pm 0.006$ & 1958 & 244701 & $0.035 \pm 0.005$ & 1958 \\
\hline 227307 & $0.121 \pm 0.009$ & 1958 & 244307 & $0.264 \pm 0.013$ & 1958 & 244702 & NoData & 1958 \\
\hline 227308 & $0.181 \pm 0.011$ & 1958 & 244308 & NoData & 1958 & 244703 & $0.584 \pm 0.020$ & 1958 \\
\hline 227309 & $0.110 \pm 0.009$ & 1958 & 244401 & $0.139 \pm 0.010$ & 1958 & 244704 & $0.197 \pm 0.011$ & 1958 \\
\hline 227310 & $0.325 \pm 0.015$ & 1958 & 244402 & $0.120 \pm 0.009$ & 1958 & 244705 & $0.045 \pm 0.006$ & 1958 \\
\hline 227311 & $0.095 \pm 0.008$ & 1958 & 244403 & $0.354 \pm 0.015$ & 1958 & 244706 & NoData & 1958 \\
\hline 224703 & $0.810 \pm 0.023$ & 1958 & 244404 & $0.145 \pm 0.010$ & 1958 & 244707 & $0.069 \pm 0.007$ & 1958 \\
\hline 228401 & $0.684 \pm 0.021$ & 1958 & 244405 & $0.017 \pm 0.003$ & 1958 & 244708 & NoData & 1958 \\
\hline 228402 & $0.104 \pm 0.008$ & 1958 & 244406 & $0.088 \pm 0.008$ & 1958 & 244709 & $0.104 \pm 0.008$ & 1958 \\
\hline 228403 & $0.038 \pm 0.005$ & 1958 & 244407 & $4.845 \pm 0.057$ & 1958 & 244710 & $0.251 \pm 0.013$ & 1958 \\
\hline 228404 & $0.404 \pm 0.016$ & 1958 & 244408 & $1.584 \pm 0.033$ & 1958 & 244711 & $0.049 \pm 0.006$ & 1958 \\
\hline 228501 & $0.068 \pm 0.007$ & 1958 & 244409 & $0.938 \pm 0.025$ & 1958 & 244712 & $0.247 \pm 0.013$ & 1958 \\
\hline
\end{tabular}




\begin{tabular}{|c|c|c|}
\hline BasinID & $\begin{array}{c}1958 \text { Area } \\
\left(\mathrm{km}^{2}\right)\end{array}$ & $\begin{array}{c}\text { Source } \\
\text { Year }\end{array}$ \\
\hline 244713 & $0.078 \pm 0.007$ & 1958 \\
\hline 244714 & NoData & 1958 \\
\hline 244801 & $0.033 \pm 0.005$ & 1958 \\
\hline 244802 & $0.036 \pm 0.005$ & 1958 \\
\hline 244805 & $0.141 \pm 0.010$ & 1958 \\
\hline 244806 & $0.064 \pm 0.007$ & 1958 \\
\hline 244807 & NoData & 1958 \\
\hline
\end{tabular}

\begin{tabular}{ccc}
\hline BasinID & $\begin{array}{c}1958 \text { Area } \\
\left(\mathrm{km}^{2}\right)\end{array}$ & $\begin{array}{c}\text { Source } \\
\text { Year } \\
244808\end{array}$ \\
$0.216 \pm 0.012$ & 1958 \\
244809 & $0.090 \pm 0.008$ & 1958 \\
244810 & $0.165 \pm 0.011$ & 1958 \\
244811 & $0.022 \pm 0.004$ & 1958 \\
245303 & $0.068 \pm 0.007$ & 1958 \\
245304 & $0.109 \pm 0.009$ & 1958 \\
245305 & NoData & 1958 \\
245306 & $0.024 \pm 0.004$ & 1958 \\
245307 & $0.034 \pm 0.005$ & 1958
\end{tabular}

\begin{tabular}{llc}
\hline BasinID & $\begin{array}{c}\text { 1958 Area } \\
\left(\mathrm{km}^{2}\right)\end{array}$ & $\begin{array}{c}\text { Source } \\
\text { Year }\end{array}$ \\
245401 & $0.017 \pm 0.003$ & 1958 \\
245402 & $0.063 \pm 0.006$ & 1958 \\
245403 & NoData & 1958 \\
245405 & $0.043 \pm 0.005$ & 1958 \\
245501 & NoData & 1958 \\
224712 & $0.109 \pm 0.009$ & 1958
\end{tabular}

\begin{tabular}{ccc}
\hline \hline BasinID & $\begin{array}{c}1968 \text { Area } \\
\left(\mathrm{km}^{2}\right)\end{array}$ & $\begin{array}{c}\text { Source } \\
\text { Year }\end{array}$ \\
\hline 211504 & $0.113 \pm 0.009$ & 1968 \\
222405 & $0.126 \pm 0.009$ & 1968 \\
223501 & $0.052 \pm 0.006$ & 1968 \\
223504 & $0.351 \pm 0.015$ & 1968 \\
223601 & $0.065 \pm 0.065$ & 1968 \\
223602 & $0.110 \pm 0.009$ & 1968 \\
223603 & $0.296 \pm 0.014$ & 1968 \\
223604 & $0.149 \pm 0.010$ & 1968 \\
223605 & $0.068 \pm 0.007$ & 1968 \\
223606 & $0.833 \pm 0.024$ & 1968 \\
223607 & $0.197 \pm 0.011$ & 1968 \\
223701 & $0.148 \pm 0.010$ & 1968 \\
223702 & $0.543 \pm 0.019$ & 1968 \\
223703 & $0.109 \pm 0.009$ & 1968 \\
224201 & $0.036 \pm 0.005$ & 1968 \\
224202 & $0.034 \pm 0.005$ & 1968 \\
224203 & $0.063 \pm 0.006$ & 1968
\end{tabular}

\begin{tabular}{ccccccc}
\hline & $\begin{array}{c}1968 \text { Area } \\
\left(\mathrm{km}^{2}\right)\end{array}$ & $\begin{array}{c}\text { Source } \\
\text { BearinID }\end{array}$ & & & $\begin{array}{c}1968 \text { Area } \\
\left(\mathrm{km}^{2}\right)\end{array}$ & $\begin{array}{c}\text { Source } \\
\text { Year }\end{array}$ \\
224404 & $0.436 \pm 0.017$ & 1968 & & 244803 & $0.252 \pm 0.013$ & 1968 \\
224405 & $1.801 \pm 0.035$ & 1968 & & 244804 & $0.021 \pm 0.004$ & 1968 \\
224501 & $0.018 \pm 0.003$ & 1968 & & 245101 & $0.039 \pm 0.005$ & 1968 \\
224502 & $0.212 \pm 0.012$ & 1968 & & 246501 & $0.059 \pm 0.006$ & 1968 \\
226602 & $1.088 \pm 0.027$ & 1963 & & 246502 & $0.060 \pm 0.006$ & 1968 \\
226603 & $0.117 \pm 0.009$ & 1963 & & 245503 & $0.035 \pm 0.005$ & 1968 \\
226604 & $0.036 \pm 0.005$ & 1963 & & 245504 & $0.022 \pm 0.004$ & 1968 \\
226701 & $0.254 \pm 0.013$ & 1963 & & 245505 & $0.017 \pm 0.003$ & 1968 \\
226702 & NoData & 1963 & & 245506 & $0.002 \pm 0.001$ & 1968 \\
226803 & $0.090 \pm 0.008$ & 1963 & & 245507 & $0.021 \pm 0.004$ & 1968 \\
226804 & $0.069 \pm 0.007$ & 1963 & & 245508 & $0.067 \pm 0.007$ & 1968 \\
226904 & NoData & 1963 & & 245509 & $0.044 \pm 0.005$ & 1968 \\
226905 & NoData & 1963 & & 246301 & $0.015 \pm 0.003$ & 1968 \\
227904 & NoData & 1963 & & 246302 & $0.046 \pm 0.006$ & 1968 \\
228307 & NoData & 1963 & & 246303 & $0.044 \pm 0.005$ & 1968 \\
228406 & $0.513 \pm 0.019$ & 1963 & & 246304 & $0.017 \pm 0.003$ & 1968 \\
228407 & $0.106 \pm 0.008$ & 1963 & & 246305 & $0.036 \pm 0.005$ & 1968 \\
242401 & $0.164 \pm 0.010$ & 1963 & & 246306 & $0.026 \pm 0.004$ & 1968 \\
242601 & $0.073 \pm 0.007$ & 1963 & & 246307 & $0.050 \pm 0.006$ & 1968
\end{tabular}

\begin{tabular}{ccc}
\hline \hline BasinID & $\begin{array}{c}1974 \text { Area } \\
\left(\mathrm{km}^{2}\right)\end{array}$ & $\begin{array}{c}\text { Source } \\
\text { Year }\end{array}$ \\
\hline 211201 & $0.048 \pm 0.006$ & 1974 \\
211202 & $0.012 \pm 0.003$ & 1974 \\
211203 & $0.081 \pm 0.007$ & 1974 \\
211204 & $0.036 \pm 0.005$ & 1974 \\
211302 & $0.057 \pm 0.006$ & 1974 \\
211305 & $0.114 \pm 0.009$ & 1974 \\
211306 & $0.025 \pm 0.004$ & 1974 \\
211401 & $0.105 \pm 0.008$ & 1974 \\
211402 & $0.120 \pm 0.009$ & 1974 \\
211403 & $0.040 \pm 0.005$ & 1974 \\
211404 & $0.020 \pm 0.004$ & 1974 \\
211405 & $0.062 \pm 0.006$ & 1974 \\
211406 & $0.047 \pm 0.006$ & 1974 \\
211407 & $0.034 \pm 0.005$ & 1974 \\
211408 & $0.143 \pm 0.010$ & 1974 \\
211409 & $0.078 \pm 0.007$ & 1974 \\
211410 & $0.036 \pm 0.005$ & 1974 \\
211411 & $0.011 \pm 0.003$ & 1974 \\
211412 & $0.086 \pm 0.008$ & 1974 \\
211413 & $0.060 \pm 0.006$ & 1974 \\
211414 & $0.028 \pm 0.004$ & 1974 \\
211415 & $0.060 \pm 0.006$ & 1974 \\
211416 & $0.048 \pm 0.006$ & 1974 \\
211801 & $0.260 \pm 0.013$ & 1974 \\
211802 & $0.179 \pm 0.011$ & 1974 \\
211803 & $0.082 \pm 0.007$ & 1974
\end{tabular}

$\begin{array}{ccc}\text { BasinID } & \begin{array}{c}1974 \text { Area } \\ \left(\mathrm{km}^{2}\right)\end{array} & \begin{array}{c}\text { Source } \\ \text { Year }\end{array} \\ 211804 & 0.509 \pm 0.018 & 1974 \\ 211901 & 0.159 \pm 0.010 & 1974 \\ 211902 & 0.097 \pm 0.008 & 1974 \\ 211905 & 0.314 \pm 0.015 & 1974 \\ 212201 & 0.538 \pm 0.019 & 1974 \\ 212202 & 0.049 \pm 0.006 & 1974 \\ 212203 & 0.043 \pm 0.005 & 1974 \\ 212204 & 0.037 \pm 0.005 & 1974 \\ 212205 & 0.093 \pm 0.008 & 1974 \\ 212206 & 0.062 \pm 0.006 & 1974 \\ 212207 & 0.076 \pm 0.007 & 1974 \\ 212208 & 0.099 \pm 0.008 & 1974 \\ 212209 & 0.136 \pm 0.010 & 1974 \\ 212210 & 0.039 \pm 0.005 & 1974 \\ 212211 & 0.041 \pm 0.005 & 1974 \\ 212212 & 0.233 \pm 0.012 & 1974 \\ 212301 & 0.034 \pm 0.005 & 1974 \\ 212302 & 0.574 \pm 0.020 & 1974 \\ 212303 & 0.577 \pm 0.020 & 1974 \\ 212304 & 2.244 \pm 0.039 & 1974 \\ 212305 & 0.166 \pm 0.011 & 1974 \\ 212306 & 1.615 \pm 0.033 & 1974 \\ 212307 & 0.106 \pm 0.008 & 1974 \\ 212401 & 0.582 \pm 0.020 & 1974 \\ 212402 & 0.807 \pm 0.023 & 1974 \\ 212403 & 0.158 \pm 0.010 & 1974 \\ & & \end{array}$

$\begin{array}{ccc}\text { BasinID } & \begin{array}{c}1974 \text { Area } \\ \left(\mathrm{km}^{2}\right)\end{array} & \begin{array}{c}\text { Source } \\ \text { Year }\end{array} \\ 212404 & 0.082 \pm 0.007 & 1974 \\ 212501 & 0.159 \pm 0.010 & 1974 \\ 212601 & 0.157 \pm 0.010 & 1974 \\ 212602 & 0.560 \pm 0.019 & 1974 \\ 212603 & 1.189 \pm 0.028 & 1975 \\ 212604 & 5.397 \pm 0.060 & 1975 \\ 212605 & 0.309 \pm 0.014 & 1975 \\ 212606 & 0.328 \pm 0.015 & 1975 \\ 212607 & 0.097 \pm 0.008 & 1975 \\ 212608 & 0.727 \pm 0.022 & 1975 \\ 212609 & 0.232 \pm 0.012 & 1975 \\ 212610 & 0.128 \pm 0.009 & 1975 \\ 212701 & 0.228 \pm 0.012 & 1975 \\ 212702 & 3.571 \pm 0.049 & 1975 \\ 212703 & 5.088 \pm 0.058 & 1975 \\ 212704 & 1.746 \pm 0.034 & 1975 \\ 213101 & 0.939 \pm 0.025 & 1975 \\ 213102 & 0.221 \pm 0.012 & 1975 \\ 213103 & \text { NoData } & 1975 \\ 213104 & 0.124 \pm 0.009 & 1975 \\ 213105 & 4.996 \pm 0.058 & 1975 \\ 213201 & \text { NoData } & 1974 \\ 213202 & 0.970 \pm 0.025 & 1974 \\ 221101 & 2.888 \pm 0.044 & 1975 \\ 221102 & 2.155 \pm 0.038 & 1975 \\ 221103 & 3.851 \pm 0.051 & 1975\end{array}$




\begin{tabular}{|c|c|c|c|c|c|c|c|c|}
\hline BasinID & $\begin{array}{c}1974 \text { Area } \\
\left(\mathrm{km}^{2}\right)\end{array}$ & $\begin{array}{c}\text { Source } \\
\text { Year }\end{array}$ & BasinID & $\begin{array}{c}1974 \text { Area } \\
\left(\mathrm{km}^{2}\right)\end{array}$ & $\begin{array}{c}\text { Source } \\
\text { Year }\end{array}$ & BasinID & $\begin{array}{c}1974 \text { Area } \\
\left(\mathrm{km}^{2}\right)\end{array}$ & $\begin{array}{c}\text { Source } \\
\text { Year }\end{array}$ \\
\hline 221104 & $3.149 \pm 0.046$ & 1975 & 221304 & $0.284 \pm 0.014$ & 1974 & 221804 & $0.276 \pm 0.014$ & 1974 \\
\hline 221105 & $0.196 \pm 0.011$ & 1975 & 221401 & $0.276 \pm 0.014$ & 1974 & 221805 & $0.241 \pm 0.013$ & 1974 \\
\hline 221106 & $0.205 \pm 0.012$ & 1975 & 221402 & $0.113 \pm 0.009$ & 1974 & 221901 & $0.779 \pm 0.023$ & 1974 \\
\hline 221107 & $0.304 \pm 0.014$ & 1975 & 221403 & $0.272 \pm 0.014$ & 1974 & 221902 & $0.111 \pm 0.009$ & 1974 \\
\hline 221108 & $1.784 \pm 0.035$ & 1975 & 221404 & $0.020 \pm 0.004$ & 1974 & 221903 & $0.144 \pm 0.010$ & 1974 \\
\hline 221109 & $0.449 \pm 0.017$ & 1975 & 221405 & $0.230 \pm 0.012$ & 1974 & 221904 & $0.269 \pm 0.013$ & 1974 \\
\hline 221201 & $0.077 \pm 0.007$ & 1974 & 221406 & $0.044 \pm 0.005$ & 1974 & 222101 & $1.294 \pm 0.029$ & 1974 \\
\hline 221202 & $0.234 \pm 0.013$ & 1974 & 221501 & $0.423 \pm 0.017$ & 1974 & 222205 & $0.890 \pm 0.024$ & 1974 \\
\hline 221203 & $0.188 \pm 0.011$ & 1974 & 221502 & $0.083 \pm 0.007$ & 1974 & 222206 & $1.149 \pm 0.028$ & 1974 \\
\hline 221204 & $0.873 \pm 0.024$ & 1974 & 221504 & $0.116 \pm 0.009$ & 1974 & 222207 & $0.112 \pm 0.009$ & 1974 \\
\hline 221205 & $0.277 \pm 0.014$ & 1974 & 221701 & $0.259 \pm 0.013$ & 1974 & 222308 & $0.159 \pm 0.010$ & 1974 \\
\hline 221206 & $0.119 \pm 0.009$ & 1974 & 221702 & $0.096 \pm 0.008$ & 1974 & 222309 & $0.287 \pm 0.014$ & 1974 \\
\hline 221301 & $3.667 \pm 0.050$ & 1974 & 221703 & $0.114 \pm 0.009$ & 1974 & 233101 & $0.244 \pm 0.013$ & 1979 \\
\hline 221302 & $2.385 \pm 0.040$ & 1974 & 221714 & $0.473 \pm 0.018$ & 1974 & 223302 & $3.397 \pm 0.048$ & 1975 \\
\hline \multirow[t]{3}{*}{221303} & $0.257 \pm 0.013$ & 1974 & 221801 & $0.250 \pm 0.013$ & 1974 & 2211011 & $2.128 \pm 0.038$ & 1975 \\
\hline & & & 221802 & $0.083 \pm 0.007$ & 1974 & 22110301 & $2.439 \pm 0.040$ & 1975 \\
\hline & & & 221803 & $0.094 \pm 0.008$ & 1974 & & & \\
\hline
\end{tabular}

\begin{tabular}{|c|c|c|c|c|c|c|c|c|}
\hline BasinID & $\begin{array}{c}1983 \text { Area } \\
\left(\mathrm{km}^{2}\right)\end{array}$ & $\begin{array}{c}\text { Source } \\
\text { Year }\end{array}$ & BasinID & $\begin{array}{c}1983 \text { Area } \\
\left(\mathrm{km}^{2}\right)\end{array}$ & $\begin{array}{c}\text { Source } \\
\text { Year }\end{array}$ & BasinID & $\begin{array}{c}1983 \text { Area } \\
\left(\mathrm{km}^{2}\right)\end{array}$ & $\begin{array}{c}\text { Source } \\
\text { Year }\end{array}$ \\
\hline 211102 & $0.035 \pm 0.005$ & 1983 & 221808 & $0.128 \pm 0.009$ & 1985 & 223305 & $0.050 \pm 0.006$ & 1983 \\
\hline 211103 & $0.015 \pm 0.003$ & 1983 & 221809 & $1.123 \pm 0.027$ & 1985 & 223401 & $0.124 \pm 0.009$ & 1983 \\
\hline 211104 & $0.530 \pm 0.019$ & 1983 & 222102 & $0.236 \pm 0.013$ & 1985 & 223402 & $0.057 \pm 0.006$ & 1983 \\
\hline 211205 & $0.015 \pm 0.003$ & 1983 & 222103 & $0.094 \pm 0.008$ & 1985 & 223403 & $0.056 \pm 0.006$ & 1983 \\
\hline 211206 & $0.081 \pm 0.007$ & 1983 & 222201 & $0.043 \pm 0.005$ & 1985 & 223404 & $0.064 \pm 0.007$ & 1983 \\
\hline 211207 & $0.021 \pm 0.004$ & 1983 & 222202 & $0.185 \pm 0.011$ & 1985 & 223405 & $0.145 \pm 0.010$ & 1983 \\
\hline 211208 & NoData & 1983 & 222204 & $0.071 \pm 0.007$ & 1985 & 223406 & $0.138 \pm 0.010$ & 1983 \\
\hline 211209 & $0.173 \pm 0.011$ & 1983 & 222208 & $0.352 \pm 0.015$ & 1985 & 223407 & $0.550 \pm 0.019$ & 1983 \\
\hline 211210 & $0.839 \pm 0.024$ & 1983 & 222209 & $0.039 \pm 0.005$ & 1985 & 223408 & $0.100 \pm 0.008$ & 1983 \\
\hline 211211 & $0.232 \pm 0.012$ & 1983 & 222301 & $0.536 \pm 0.019$ & 1983 & 223502 & $0.523 \pm 0.019$ & 1983 \\
\hline 211501 & $0.109 \pm 0.109$ & 1983 & 222302 & $0.210 \pm 0.012$ & 1983 & 223503 & $0.226 \pm 0.012$ & 1983 \\
\hline 211503 & $0.048 \pm 0.006$ & 1983 & 222303 & $0.125 \pm 0.009$ & 1983 & 223611 & $0.309 \pm 0.014$ & 1983 \\
\hline 211505 & $0.120 \pm 0.009$ & 1983 & 222304 & NoData & 1983 & 223612 & $0.200 \pm 0.012$ & 1983 \\
\hline 211506 & $2.041 \pm 0.037$ & 1983 & 222305 & $0.205 \pm 0.012$ & 1983 & 226110 & $0.405 \pm 0.016$ & 1983 \\
\hline 211507 & $1.177 \pm 0.028$ & 1983 & 222306 & $0.211 \pm 0.012$ & 1983 & 227312 & $0.324 \pm 0.015$ & 1984 \\
\hline 211508 & $0.430 \pm 0.017$ & 1983 & 222307 & $0.084 \pm 0.007$ & 1983 & 227313 & $0.218 \pm 0.012$ & 1984 \\
\hline 211509 & $0.181 \pm 0.011$ & 1983 & 222310 & $0.054 \pm 0.006$ & 1983 & 227402 & $0.171 \pm 0.011$ & 1984 \\
\hline 211510 & $0.176 \pm 0.011$ & 1983 & 222311 & $0.150 \pm 0.010$ & 1983 & 227501 & $0.155 \pm 0.010$ & 1984 \\
\hline 211601 & $0.038 \pm 0.039$ & 1983 & 222312 & $0.103 \pm 0.008$ & 1983 & 227502 & $0.053 \pm 0.006$ & 1984 \\
\hline 211603 & $0.196 \pm 0.011$ & 1983 & 222313 & $0.235 \pm 0.013$ & 1983 & 227503 & NoData & 1984 \\
\hline 211604 & NoData & 1983 & 222314 & $0.728 \pm 0.022$ & 1983 & 227504 & NoData & 1984 \\
\hline 211701 & $0.046 \pm 0.006$ & 1983 & 222315 & $0.190 \pm 0.011$ & 1983 & 227505 & $0.413 \pm 0.017$ & 1984 \\
\hline 211702 & $0.040 \pm 0.005$ & 1983 & 222316 & NoData & 1983 & 227506 & $0.314 \pm 0.015$ & 1984 \\
\hline 212101 & $0.172 \pm 0.011$ & 1983 & 222404 & $0.169 \pm 0.011$ & 1983 & 227507 & $0.027 \pm 0.004$ & 1984 \\
\hline 212102 & $0.016 \pm 0.003$ & 1983 & 222406 & $0.097 \pm 0.008$ & 1983 & 227508 & $3.432 \pm 0.048$ & 1984 \\
\hline 221503 & $0.178 \pm 0.011$ & 1983 & 222407 & NoData & 1983 & 227601 & $0.143 \pm 0.010$ & 1984 \\
\hline 221601 & $0.088 \pm 0.008$ & 1983 & 222408 & $0.286 \pm 0.014$ & 1983 & 227602 & $0.171 \pm 0.011$ & 1984 \\
\hline 221602 & $0.113 \pm 0.009$ & 1983 & 222603 & $0.355 \pm 0.015$ & 1983 & 227603 & $2.963 \pm 0.045$ & 1984 \\
\hline 221603 & $0.798 \pm 0.023$ & 1983 & 222701 & $0.166 \pm 0.011$ & 1983 & 227604 & $0.870 \pm 0.024$ & 1984 \\
\hline 221604 & $0.160 \pm 0.010$ & 1983 & 223101 & $0.533 \pm 0.019$ & 1983 & 227605 & $1.561 \pm 0.032$ & 1984 \\
\hline 221605 & $0.200 \pm 0.012$ & 1983 & 22 & $0.945 \pm 0.025$ & 1983 & 606 & $1.698 \pm 0.034$ & 1984 \\
\hline 221606 & $0.697 \pm 0.022$ & 1983 & 03 & $0.142 \pm 0.010$ & 1983 & 227607 & $2.525 \pm 0.041$ & 1984 \\
\hline 221704 & $0.438 \pm 0.017$ & 1985 & 223104 & $0.105 \pm 0.008$ & 1983 & 227608 & $1.087 \pm 0.027$ & 1984 \\
\hline 221705 & $0.103 \pm 0.008$ & 1985 & 223105 & $0.629 \pm 0.021$ & 1983 & 227609 & $1.376 \pm 0.030$ & 1984 \\
\hline 221706 & $0.153 \pm 0.010$ & 1985 & 223201 & $0.122 \pm 0.009$ & 1983 & 227701 & $0.279 \pm 0.014$ & 1984 \\
\hline 221707 & $0.085 \pm 0.008$ & 1985 & 223202 & $0.358 \pm 0.015$ & 1983 & 227702 & $1.494 \pm 0.032$ & 1984 \\
\hline 221708 & $0.100 \pm 0.008$ & 1985 & 223203 & $0.393 \pm 0.016$ & 1983 & 227703 & $1.009 \pm 0.026$ & 1984 \\
\hline 221709 & $0.140 \pm 0.010$ & 1985 & 223204 & $0.375 \pm 0.016$ & 1983 & 227801 & $0.139 \pm 0.010$ & 1984 \\
\hline 221710 & $0.071 \pm 0.007$ & 1985 & 223205 & $1.775 \pm 0.034$ & 1983 & 227802 & $1.205 \pm 0.028$ & 1984 \\
\hline 221711 & $0.131 \pm 0.009$ & 1985 & 223206 & $0.307 \pm 0.014$ & 1983 & 227803 & $0.256 \pm 0.013$ & 1984 \\
\hline 221712 & $0.041 \pm 0.005$ & 1985 & 223207 & $0.986 \pm 0.026$ & 1983 & 228101 & $1.569 \pm 0.032$ & 1984 \\
\hline 221713 & $0.066 \pm 0.007$ & 1985 & 223301 & $1.008 \pm 0.026$ & 1983 & 228102 & $0.786 \pm 0.023$ & 1984 \\
\hline 221807 & NoData & 1985 & 223304 & $0.371 \pm 0.016$ & 1983 & 228103 & $0.090 \pm 0.008$ & 1984 \\
\hline
\end{tabular}




\begin{tabular}{|c|c|c|c|c|c|c|c|c|}
\hline BasinID & $\begin{array}{c}1983 \text { Area } \\
\left(\mathrm{km}^{2}\right)\end{array}$ & $\begin{array}{c}\text { Source } \\
\text { Year }\end{array}$ & BasinID & $\begin{array}{c}1983 \text { Area } \\
\left(\mathrm{km}^{2}\right)\end{array}$ & $\begin{array}{c}\text { Source } \\
\text { Year }\end{array}$ & BasinID & $\begin{array}{c}1983 \text { Area } \\
\left(\mathrm{km}^{2}\right)\end{array}$ & $\begin{array}{c}\text { Source } \\
\text { Year }\end{array}$ \\
\hline 228104 & $0.355 \pm 0.015$ & 1984 & 242703 & NoData & 1984 & 243204 & $0.331 \pm 0.015$ & 1984 \\
\hline 228105 & $0.514 \pm 0.019$ & 1984 & 242704 & $0.060 \pm 0.006$ & 1984 & 243205 & $0.141 \pm 0.010$ & 1984 \\
\hline 228201 & $0.365 \pm 0.016$ & 1984 & 242705 & $0.074 \pm 0.007$ & 1984 & 244201 & $0.178 \pm 0.011$ & 1984 \\
\hline 228202 & $0.247 \pm 0.013$ & 1984 & 242706 & $0.905 \pm 0.025$ & 1984 & 244202 & $0.200 \pm 0.012$ & 1984 \\
\hline 228203 & $2.822 \pm 0.043$ & 1984 & 242707 & $1.287 \pm 0.029$ & 1984 & 244204 & $0.186 \pm 0.011$ & 1984 \\
\hline 228204 & $0.142 \pm 0.010$ & 1984 & 242708 & $0.424 \pm 0.017$ & 1984 & 244205 & $0.238 \pm 0.013$ & 1984 \\
\hline 231101 & $0.382 \pm 0.016$ & 1983 & 242709 & $0.142 \pm 0.010$ & 1984 & 244207 & $0.192 \pm 0.011$ & 1984 \\
\hline 231102 & $0.077 \pm 0.007$ & 1983 & 242801 & $0.080 \pm 0.007$ & 1984 & 244209 & NoData & 1984 \\
\hline 231103 & $0.047 \pm 0.006$ & 1983 & 242802 & $0.319 \pm 0.015$ & 1984 & 244210 & $0.084 \pm 0.008$ & 1984 \\
\hline 231104 & $0.132 \pm 0.009$ & 1983 & 242803 & $0.089 \pm 0.008$ & 1984 & 244211 & $0.044 \pm 0.005$ & 1984 \\
\hline 231105 & $0.649 \pm 0.021$ & 1983 & 242804 & $0.127 \pm 0.009$ & 1984 & 244212 & $0.058 \pm 0.006$ & 1984 \\
\hline 242606 & $0.114 \pm 0.009$ & 1984 & 242805 & $0.057 \pm 0.006$ & 1984 & 244213 & $0.464 \pm 0.018$ & 1984 \\
\hline 242607 & $0.244 \pm 0.013$ & 1984 & 243101 & $0.019 \pm 0.004$ & 1984 & 244214 & NoData & 1984 \\
\hline 242608 & $0.267 \pm 0.013$ & 1984 & 243102 & $0.106 \pm 0.008$ & 1984 & 244215 & $0.117 \pm 0.009$ & 1984 \\
\hline 242609 & $0.124 \pm 0.009$ & 1984 & 243103 & $0.087 \pm 0.008$ & 1984 & 244217 & $0.527 \pm 0.019$ & 1984 \\
\hline 242610 & $1.291 \pm 0.029$ & 1984 & 243104 & $0.056 \pm 0.006$ & 1984 & 244218 & NoData & 1984 \\
\hline 242611 & $0.328 \pm 0.015$ & 1984 & 243105 & $0.094 \pm 0.008$ & 1984 & 244220 & $0.075 \pm 0.007$ & 1984 \\
\hline 242612 & $0.526 \pm 0.019$ & 1984 & 243106 & $0.084 \pm 0.007$ & 1984 & 244221 & $1.252 \pm 0.029$ & 1984 \\
\hline \multirow[t]{3}{*}{242701} & $1.312 \pm 0.030$ & 1984 & 243201 & $0.125 \pm 0.009$ & 1984 & 244222 & $0.207 \pm 0.012$ & 1984 \\
\hline & & & 243202 & $0.121 \pm 0.009$ & 1984 & 244303 & $0.364 \pm 0.016$ & 1984 \\
\hline & & & 243203 & $0.803 \pm 0.023$ & 1984 & 245302 & $0.075 \pm 0.007$ & 1985 \\
\hline
\end{tabular}

\begin{tabular}{|c|c|c|c|c|c|c|c|c|}
\hline BasinID & $\begin{array}{c}1990 \text { Area } \\
\left(\mathrm{km}^{2}\right)\end{array}$ & $\begin{array}{c}\begin{array}{c}\text { Source } \\
\text { Year }\end{array} \\
\text { (a) }\end{array}$ & BasinID & $\begin{array}{c}1990 \text { Area } \\
\left(\mathrm{km}^{2}\right)\end{array}$ & $\begin{array}{c}\text { Source } \\
\text { Year }\end{array}$ & BasinID & $\begin{array}{c}1990 \text { Area } \\
\left(\mathrm{km}^{2}\right)\end{array}$ & $\begin{array}{c}\text { Source } \\
\text { Year }\end{array}$ \\
\hline 211101 & $0.031 \pm 0.010$ & 1993 & 212102 & $0.016 \pm 0.010$ & 1993 & 222309 & $0.297 \pm 0.012$ & 1990 \\
\hline 211103 & $0.015 \pm 0.010$ & 1993 & 212403 & $0.158 \pm 0.011$ & 1993 & 222310 & $0.031 \pm 0.010$ & 1990 \\
\hline 211104 & $0.514 \pm 0.014$ & 1993 & 212404 & $0.065 \pm 0.011$ & 1993 & 222311 & $0.121 \pm 0.011$ & 1990 \\
\hline 211207 & $0.019 \pm 0.010$ & 1993 & 212501 & $0.132 \pm 0.011$ & 1993 & 222312 & $0.112 \pm 0.011$ & 1990 \\
\hline 211208 & $0.043 \pm 0.010$ & 1993 & 212601 & $0.153 \pm 0.011$ & 1993 & 222313 & $0.229 \pm 0.012$ & 1990 \\
\hline 211209 & $0.168 \pm 0.011$ & 1993 & 212602 & $0.508 \pm 0.014$ & 1993 & 222314 & $0.770 \pm 0.015$ & 1990 \\
\hline 211210 & $0.778 \pm 0.015$ & 1993 & 212603 & $1.307 \pm 0.018$ & 1993 & 222315 & $0.169 \pm 0.011$ & 1990 \\
\hline 211211 & $0.228 \pm 0.012$ & 1993 & 212604 & $5.282 \pm 0.031$ & 1993 & 222316 & $0.175 \pm 0.011$ & 1990 \\
\hline 211403 & $0.037 \pm 0.010$ & 1990 & 212605 & $0.356 \pm 0.013$ & 1993 & 222401 & $0.254 \pm 0.012$ & 1990 \\
\hline 211405 & $0.061 \pm 0.010$ & 1990 & 212701 & NoData & 1993 & 222403 & $0.245 \pm 0.012$ & 1990 \\
\hline 211406 & $0.037 \pm 0.010$ & 1990 & 212702 & $3.915 \pm 0.027$ & 1993 & 222404 & $0.140 \pm 0.011$ & 1990 \\
\hline 211407 & $0.031 \pm 0.010$ & 1990 & 212703 & $4.886 \pm 0.030$ & 1993 & 222405 & $0.109 \pm 0.011$ & 1990 \\
\hline 211408 & $0.125 \pm 0.011$ & 1990 & 213105 & $5.058 \pm 0.030$ & 1990 & 222406 & $0.123 \pm 0.011$ & 1990 \\
\hline 211409 & $0.076 \pm 0.011$ & 1990 & 221101 & $2.823 \pm 0.024$ & 1993 & 222407 & $0.086 \pm 0.011$ & 1990 \\
\hline 211410 & $0.035 \pm 0.010$ & 1990 & 221103 & $3.638 \pm 0.026$ & 1993 & 222501 & $0.503 \pm 0.013$ & 1990 \\
\hline 211414 & NoData & 1990 & 221104 & $3.252 \pm 0.025$ & 1993 & 222601 & $0.080 \pm 0.011$ & 1989 \\
\hline 211415 & $0.064 \pm 0.011$ & 1990 & 221108 & $1.799 \pm 0.020$ & 1993 & 222602 & $0.074 \pm 0.011$ & 1989 \\
\hline 211501 & $0.123 \pm$ & 1990 & 221201 & NoData & 1993 & 222603 & $0.285 \pm 0.012$ & 1989 \\
\hline 211503 & $0.034 \pm 0.010$ & 1990 & 221202 & $0.214 \pm 0.012$ & 1993 & 222701 & $0.136 \pm 0.011$ & 1989 \\
\hline 211504 & NoData & 1990 & 221203 & $0.170 \pm 0.011$ & 1993 & 223101 & $0.510 \pm 0.014$ & 1990 \\
\hline 211506 & $1.978 \pm 0.021$ & 1990 & 221501 & $0.378 \pm 0.013$ & 1990 & 223102 & $0.873 \pm 0.016$ & 1990 \\
\hline 211507 & $1.092 \pm 0.017$ & 1990 & 221502 & $0.087 \pm 0.011$ & 1990 & 223103 & $0.136 \pm 0$ & 1990 \\
\hline 211508 & $0.361 \pm 0.013$ & 1990 & 221503 & $0.149 \pm 0$ & 1990 & 223104 & $0.108 \pm 0$ & 1990 \\
\hline 211509 & $0.173 \pm 0.011$ & 1990 & 04 & $0.100 \pm$ & 1990 & 05 & $0.615=$ & 1990 \\
\hline 211510 & $0.184 \pm 0.011$ & 1990 & & $0.110 \pm 0$ & 1990 & 223201 & $0.124 \pm 0.011$ & 1990 \\
\hline 211601 & 0.04 & 1990 & 603 & $0.788 \pm 0.015$ & 1990 & 223202 & $0.336 \pm 0.012$ & 1990 \\
\hline 211603 & $0.154 \pm 0.011$ & 1990 & 221604 & $0.159 \pm 0.011$ & 1990 & 223203 & $0.380 \pm 0.013$ & 1990 \\
\hline 211604 & NoData & 1990 & 221605 & $0.161 \pm 0.011$ & 1990 & 223204 & $0.377 \pm 0.013$ & 1990 \\
\hline 211701 & $0.048 \pm 0.010$ & 1990 & 221606 & $0.661 \pm 0.014$ & 1990 & 223205 & $1.746 \pm 0.020$ & 1990 \\
\hline 211702 & $0.041 \pm 0.010$ & 1990 & 221701 & $0.266 \pm 0.012$ & 1990 & 223206 & $0.314 \pm 0.012$ & 1990 \\
\hline 211801 & $0.225 \pm 0.012$ & 1990 & 221702 & $0.094 \pm 0.011$ & 1990 & 223207 & $1.012 \pm 0.016$ & 1990 \\
\hline 211802 & $0.172 \pm 0.011$ & 1990 & 221703 & $0.106 \pm 0.011$ & 1990 & 223302 & $3.311 \pm 0.025$ & 1990 \\
\hline 211803 & $0.084 \pm 0.011$ & 1990 & 221713 & $0.063 \pm 0.010$ & 1990 & 223303 & $0.369 \pm 0.013$ & 1990 \\
\hline 211804 & $0.502 \pm 0.013$ & 1990 & 221801 & $0.244 \pm 0.012$ & 1990 & 223304 & $0.334 \pm 0.012$ & 1990 \\
\hline 211901 & $0.170 \pm 0.011$ & 1990 & & $0.264 \pm 0.012$ & 1990 & 223305 & NoData & 1990 \\
\hline 211902 & $0.099 \pm 0.011$ & 1990 & 221805 & $0.216 \pm 0.012$ & 1990 & 223401 & $0.126 \pm 0.011$ & 1990 \\
\hline 212101 & $0.173 \pm 0.011$ & 1993 & 222308 & $0.160 \pm 0.011$ & 1990 & 223402 & $0.060 \pm 0.010$ & 1990 \\
\hline
\end{tabular}




\begin{tabular}{|c|c|c|c|c|c|c|c|c|}
\hline BasinID & $\begin{array}{c}1990 \text { Area } \\
\left(\mathrm{km}^{2}\right)\end{array}$ & $\begin{array}{c}\text { Source } \\
\text { Year }\end{array}$ & BasinID & $\begin{array}{c}1990 \text { Area } \\
\left(\mathrm{km}^{2}\right)\end{array}$ & $\begin{array}{c}\text { Source } \\
\text { Year }\end{array}$ & BasinID & $\begin{array}{c}1990 \text { Area } \\
\left(\mathrm{km}^{2}\right)\end{array}$ & $\begin{array}{c}\text { Source } \\
\text { Year }\end{array}$ \\
\hline 223403 & $0.055 \pm 0.010$ & 1990 & 226102 & $0.062 \pm 0.010$ & 1989 & 243103 & $0.083 \pm 0.011$ & 1992 \\
\hline 223405 & $0.154 \pm 0.011$ & 1990 & 226103 & $0.778 \pm 0.015$ & 1989 & 243104 & $0.053 \pm 0.010$ & 1992 \\
\hline 223406 & $0.140 \pm 0.011$ & 1990 & 226104 & $0.135 \pm 0.011$ & 1989 & 243105 & $0.095 \pm 0.011$ & 1992 \\
\hline 223407 & $0.535 \pm 0.014$ & 1990 & 226105 & $0.374 \pm 0.013$ & 1989 & 243106 & $0.037 \pm 0.010$ & 1992 \\
\hline 223501 & $0.055 \pm 0.010$ & 1990 & 226106 & $0.182 \pm 0.011$ & 1989 & 243201 & $0.096 \pm 0.011$ & 1992 \\
\hline 223502 & $0.485 \pm 0.013$ & 1990 & 226107 & $0.106 \pm 0.011$ & 1989 & 243202 & $0.096 \pm 0.011$ & 1992 \\
\hline 223503 & $0.224 \pm 0.012$ & 1990 & 226108 & $0.294 \pm 0.012$ & 1989 & 243203 & $0.660 \pm 0.014$ & 1992 \\
\hline 223504 & $0.376 \pm 0.013$ & 1990 & 226109 & $0.244 \pm 0.012$ & 1989 & 243204 & $0.307 \pm 0.012$ & 1992 \\
\hline 223601 & NoData & 1990 & 226110 & $0.362 \pm 0.013$ & 1989 & 243205 & $0.119 \pm 0.011$ & 1992 \\
\hline 223602 & $0.121 \pm 0.011$ & 1990 & 226201 & $0.083 \pm 0.011$ & 1989 & 244201 & $0.187 \pm 0.011$ & 1992 \\
\hline 223603 & $0.270 \pm 0.012$ & 1990 & 226202 & $0.078 \pm 0.011$ & 1989 & 244202 & $0.185 \pm 0.011$ & 1992 \\
\hline 223604 & NoData & 1990 & 226208 & $0.167 \pm 0.011$ & 1990 & 244203 & $0.034 \pm 0.010$ & 1992 \\
\hline 223605 & $0.074 \pm 0.011$ & 1990 & 226410 & $0.029 \pm 0.010$ & 1989 & 244204 & $0.144 \pm 0.011$ & 1992 \\
\hline 223606 & $0.752 \pm 0.015$ & 1990 & 226411 & $0.078 \pm 0.011$ & 1989 & 244205 & $0.214 \pm 0.012$ & 1992 \\
\hline 223607 & NoData & 1990 & 226412 & $0.055 \pm 0.010$ & 1989 & 244206 & $0.047 \pm 0.010$ & 1992 \\
\hline 223608 & $0.336 \pm 0.012$ & 1990 & 226601 & $0.033 \pm 0.010$ & 1989 & 244207 & $0.186 \pm 0.011$ & 1992 \\
\hline 223609 & $0.077 \pm 0.011$ & 1990 & 227311 & $0.100 \pm 0.011$ & 1992 & 244209 & $0.048 \pm 0.010$ & 1992 \\
\hline 223610 & $0.567 \pm 0.014$ & 1990 & 224703 & $0.816 \pm 0.015$ & 1990 & 244210 & $0.106 \pm 0.011$ & 1992 \\
\hline 223611 & $0.285 \pm 0.012$ & 1990 & 227903 & $0.099 \pm 0.011$ & 1989 & 244211 & $0.045 \pm 0.010$ & 1992 \\
\hline 223612 & $0.172 \pm 0.011$ & 1990 & 227904 & $0.132 \pm 0.011$ & 1989 & 244212 & $0.046 \pm 0.010$ & 1992 \\
\hline 223701 & $0.097 \pm 0.011$ & 1990 & 228307 & $0.065 \pm 0.011$ & 1989 & 244217 & $0.492 \pm 0.013$ & 1992 \\
\hline 223702 & $0.571 \pm 0.014$ & 1990 & 228401 & $0.678 \pm 0.014$ & 1989 & 244218 & $0.738 \pm 0.015$ & 1992 \\
\hline 223703 & $0.073 \pm 0.011$ & 1990 & 228402 & $0.112 \pm 0.011$ & 1989 & 244220 & $0.070 \pm 0.011$ & 1992 \\
\hline 224201 & $0.028 \pm 0.010$ & 1990 & 228403 & NoData & 1989 & 244221 & $1.223 \pm 0.017$ & 1992 \\
\hline 224202 & $0.027 \pm 0.010$ & 1990 & 228404 & $0.390 \pm 0.013$ & 1989 & 244222 & $0.201 \pm 0.012$ & 1992 \\
\hline 224203 & $0.057 \pm 0.010$ & 1990 & 228406 & $0.406 \pm 0.013$ & 1989 & 244223 & $0.019 \pm 0.010$ & 1992 \\
\hline 224404 & $0.425 \pm 0.013$ & 1990 & 228407 & $0.090 \pm 0.011$ & 1989 & 244301 & $0.005 \pm 0.010$ & 1992 \\
\hline 224405 & $1.621 \pm 0.019$ & 1990 & 228501 & $0.064 \pm 0.011$ & 1989 & 244302 & $0.684 \pm 0.015$ & 1992 \\
\hline 224501 & $0.016 \pm 0.010$ & 1990 & 228503 & $0.090 \pm 0.011$ & 1989 & 244306 & NoData & 1992 \\
\hline 224502 & $0.154 \pm 0.011$ & 1990 & 228504 & $0.028 \pm 0.010$ & 1989 & 244308 & $0.257 \pm 0.012$ & 1992 \\
\hline 224603 & $0.083 \pm 0.011$ & 1990 & 228505 & $0.108 \pm 0.011$ & 1989 & 244401 & NoData & 1992 \\
\hline 224604 & $0.047 \pm 0.010$ & 1990 & 228603 & $0.170 \pm 0.011$ & 1989 & 244402 & $0.123 \pm 0.011$ & 1992 \\
\hline 224610 & $0.034 \pm 0.010$ & 1990 & 228604 & $0.256 \pm 0.012$ & 1989 & 244403 & $0.365 \pm 0.013$ & 1992 \\
\hline 224701 & $0.550 \pm 0.014$ & 1990 & 231101 & $0.352 \pm 0.013$ & 1989 & 244404 & $0.063 \pm 0.010$ & 1992 \\
\hline 224702 & $0.225 \pm 0.012$ & 1990 & 231102 & NoData & 1989 & 244406 & $0.093 \pm 0.011$ & 1992 \\
\hline 224703 & $0.816 \pm 0.015$ & 1990 & 231103 & NoData & 1989 & 244611 & $0.499 \pm 0.013$ & 1990 \\
\hline 224704 & $0.148 \pm 0.011$ & 1990 & 231104 & $0.148 \pm 0.011$ & 1989 & 244612 & $0.040 \pm 0.010$ & 1992 \\
\hline 224706 & $0.772 \pm 0.015$ & 1990 & 231105 & $0.697 \pm 0.015$ & 1989 & 244613 & NoData & 1992 \\
\hline 224714 & $0.217 \pm 0.012$ & 1990 & 233101 & $0.203 \pm 0.012$ & 1989 & 244614 & NoData & 1992 \\
\hline 224801 & $0.075 \pm 0.011$ & 1990 & 233201 & $0.045 \pm 0.010$ & 1989 & 244615 & NoData & 1992 \\
\hline 225114 & $0.610 \pm 0.014$ & 1990 & 233202 & $0.041 \pm 0.010$ & 1989 & 244616 & $0.061 \pm 0.010$ & 1992 \\
\hline 225205 & $6.675 \pm 0.034$ & 1990 & 233203 & $0.072 \pm 0.011$ & 1989 & 244617 & NoData & 1992 \\
\hline 225301 & $0.090 \pm 0.011$ & 1990 & 233204 & $0.821 \pm 0.015$ & 1989 & 244618 & $0.023 \pm 0.010$ & 1992 \\
\hline 225303 & $1.862 \pm 0.020$ & 1990 & 233205 & $0.090 \pm 0.011$ & 1989 & 244619 & NoData & 1992 \\
\hline 225305 & $0.110 \pm 0.011$ & 1990 & 233206 & $0.079 \pm 0.011$ & 1989 & 244621 & $0.335 \pm 0.012$ & 1992 \\
\hline 225306 & $4.662 \pm 0.029$ & 1990 & 233207 & $0.025 \pm 0.010$ & 1989 & 244622 & $0.322 \pm 0.012$ & 1992 \\
\hline 225307 & NoData & 1990 & 233209 & $0.026 \pm 0.010$ & 1989 & 244623 & $0.070 \pm 0.011$ & 1992 \\
\hline 225309 & $2.215 \pm 0.021$ & 1990 & 242201 & $0.038 \pm 0.010$ & 1992 & 244701 & $0.028 \pm 0.010$ & 1992 \\
\hline 225310 & $1.735 \pm 0.020$ & 1990 & 242202 & $0.093 \pm 0.011$ & 1992 & 244702 & $0.088 \pm 0.011$ & 1992 \\
\hline 225401 & $0.231 \pm 0.012$ & 1990 & 242203 & $0.103 \pm 0.011$ & 1992 & 244703 & $0.541 \pm 0.014$ & 1992 \\
\hline 225501 & $1.165 \pm 0.017$ & 1990 & 242204 & $0.016 \pm 0.010$ & 1992 & 244704 & NoData & 1992 \\
\hline 225502 & $0.069 \pm 0.011$ & 1990 & 242205 & $0.019 \pm 0.010$ & 1992 & 244707 & $0.055 \pm 0.010$ & 1992 \\
\hline 225503 & $0.063 \pm 0.011$ & 1990 & 242206 & $0.030 \pm 0.010$ & 1992 & 244708 & $0.964 \pm 0.016$ & 1992 \\
\hline 225505 & $0.209 \pm 0.012$ & 1990 & 242207 & $0.126 \pm 0.011$ & 1992 & 244714 & NoData & 1990 \\
\hline 225506 & $0.150 \pm 0.011$ & 1989 & 242208 & $0.052 \pm 0.010$ & 1992 & 244802 & $0.031 \pm C$ & 1990 \\
\hline 225510 & $0.261 \pm 0.012$ & 1989 & 242209 & $0.077 \pm 0.011$ & 1992 & 244803 & $0.225 \pm 0.012$ & 1990 \\
\hline 225511 & $0.096 \pm 0.011$ & 1989 & 242210 & $0.013 \pm 0.010$ & 1992 & 244808 & $0.222 \pm 0.012$ & 1990 \\
\hline 225512 & $0.799 \pm 0.015$ & 1989 & 242211 & $0.093 \pm 0.011$ & 1992 & 244809 & $0.097 \pm 0.011$ & 1990 \\
\hline 225513 & $0.107 \pm 0.011$ & 1989 & 242212 & $0.158 \pm 0.011$ & 1992 & 244811 & $0.022 \pm 0.010$ & 1990 \\
\hline 225514 & $0.201 \pm 0.012$ & 1989 & 242213 & $0.070 \pm 0.011$ & 1992 & 245101 & $0.043 \pm 0.010$ & 1990 \\
\hline 225601 & $0.198 \pm 0.011$ & 1990 & 242601 & $0.070 \pm 0.011$ & 1992 & 245302 & NoData & 1990 \\
\hline 225602 & $3.933 \pm 0.027$ & 1990 & 242805 & $0.045 \pm 0.010$ & 1992 & 245303 & $0.064 \pm 0.011$ & 1990 \\
\hline 225701 & $1.032 \pm 0.016$ & 1990 & 243101 & $0.018 \pm 0.010$ & 1992 & 245304 & NoData & 1990 \\
\hline 226101 & $0.049 \pm 0.010$ & 1989 & 243102 & $0.106 \pm 0.011$ & 1992 & 245305 & $0.141 \pm 0.011$ & 1990 \\
\hline
\end{tabular}




\begin{tabular}{|c|c|c|c|c|c|c|c|c|}
\hline BasinID & $\begin{array}{c}1990 \text { Area } \\
\left(\mathrm{km}^{2}\right)\end{array}$ & $\begin{array}{c}\text { Source } \\
\text { Year }\end{array}$ & BasinID & $\begin{array}{c}1990 \text { Area } \\
\left(\mathrm{km}^{2}\right)\end{array}$ & $\begin{array}{l}\text { Source } \\
\text { Year }\end{array}$ & BasinID & $\begin{array}{c}1990 \text { Area } \\
\left(\mathrm{km}^{2}\right)\end{array}$ & $\begin{array}{c}\text { Source } \\
\text { Year }\end{array}$ \\
\hline 245306 & NoData & 1990 & 245501 & NoData & 1990 & 246301 & $0.014 \pm 0.010$ & 1990 \\
\hline 245307 & $0.026 \pm 0.010$ & 1990 & 246501 & $0.057 \pm 0.010$ & 1990 & 246302 & NoData & 1990 \\
\hline 245401 & $0.016 \pm 0.010$ & 1990 & 246502 & $0.045 \pm 0.010$ & 1990 & 246303 & $0.047 \pm 0.010$ & 1990 \\
\hline 245402 & NoData & 1990 & 245503 & NoData & 1990 & 246304 & $0.018 \pm 0.010$ & 1990 \\
\hline 245403 & $0.043 \pm 0.010$ & 1990 & 245504 & NoData & 1990 & 246305 & $0.018 \pm 0.010$ & 1990 \\
\hline \multirow[t]{3}{*}{245405} & $0.044 \pm 0.010$ & 1990 & 245507 & $0.021 \pm 0.010$ & 1990 & 246306 & NoData & 1990 \\
\hline & & & 245508 & $0.043 \pm 0.010$ & 1990 & 246307 & $0.046 \pm 0.010$ & 1990 \\
\hline & & & 245509 & $0.026 \pm 0.010$ & 1990 & & & \\
\hline
\end{tabular}

\begin{tabular}{|c|c|c|c|c|c|c|c|}
\hline BasinID & $\begin{array}{c}1998 \text { Area } \\
\left(\mathrm{km}^{2}\right)\end{array}$ & BasinID & $\begin{array}{c}1998 \text { Area } \\
\left(\mathrm{km}^{2}\right)\end{array}$ & BasinID & $\begin{array}{c}1998 \text { Area } \\
\left(\mathrm{km}^{2}\right)\end{array}$ & BasinID & $\begin{array}{c}1998 \text { Area } \\
\left(\mathrm{km}^{2}\right)\end{array}$ \\
\hline 211201 & $0.038 \pm 0.010$ & 212204 & $0.038 \pm 0.010$ & 221709 & $0.128 \pm 0.011$ & 222408 & $0.249 \pm 0.012$ \\
\hline 211202 & $0.009 \pm 0.010$ & 212205 & $0.067 \pm 0.011$ & 221710 & $0.069 \pm 0.011$ & 222501 & $0.467 \pm 0.013$ \\
\hline 211203 & $0.053 \pm 0.010$ & 212206 & $0.052 \pm 0.010$ & 221711 & $0.124 \pm 0.011$ & 222502 & $0.203 \pm 0.012$ \\
\hline 211204 & $0.038 \pm 0.010$ & 212207 & $0.070 \pm 0.011$ & 221712 & $0.041 \pm 0.010$ & 222601 & $0.091 \pm 0.011$ \\
\hline 211301 & NoData & 212208 & $0.093 \pm 0.011$ & 221713 & $0.062 \pm 0.010$ & 222602 & $0.085 \pm 0.011$ \\
\hline 211302 & $0.046 \pm 0.010$ & 212209 & $0.128 \pm 0.011$ & 221714 & $0.390 \pm 0.013$ & 222603 & $0.255 \pm 0.012$ \\
\hline 211303 & $0.025 \pm 0.010$ & 212210 & $0.038 \pm 0.010$ & 221801 & $0.231 \pm 0.012$ & 222701 & $0.157 \pm 0.011$ \\
\hline 211304 & $0.016 \pm 0.010$ & 212211 & $0.037 \pm 0.010$ & 221802 & $0.064 \pm 0.011$ & 223101 & $0.517 \pm 0.014$ \\
\hline 211305 & $0.090 \pm 0.011$ & 212212 & $0.251 \pm 0.012$ & 221803 & $0.081 \pm 0.011$ & 223102 & $0.873 \pm 0.016$ \\
\hline 211306 & $0.024 \pm 0.010$ & 212301 & $0.039 \pm 0.010$ & 221804 & $0.242 \pm 0.012$ & 223103 & $0.111 \pm 0.011$ \\
\hline 211307 & $0.054 \pm 0.010$ & 212302 & $0.566 \pm 0.014$ & 221805 & $0.186 \pm 0.011$ & 223104 & $0.079 \pm 0.011$ \\
\hline 211401 & $0.092 \pm 0.011$ & 212303 & $0.521 \pm 0.014$ & 221808 & $0.131 \pm 0.011$ & 223105 & $0.601 \pm 0.014$ \\
\hline 211402 & $0.091 \pm 0.011$ & 212304 & $2.266 \pm 0.022$ & 221809 & $1.121 \pm 0.017$ & 223201 & $0.134 \pm 0.011$ \\
\hline 211403 & $0.040 \pm 0.010$ & 212305 & $0.127 \pm 0.011$ & 221901 & $0.723 \pm 0.015$ & 223202 & $0.313 \pm 0.012$ \\
\hline 211404 & $0.020 \pm 0.010$ & 212306 & $1.535 \pm 0.019$ & 221902 & $0.117 \pm 0.011$ & 223203 & $0.372 \pm 0.013$ \\
\hline 211405 & $0.051 \pm 0.010$ & 212307 & $0.097 \pm 0.011$ & 221903 & $0.111 \pm 0.011$ & 223204 & $0.300 \pm 0.012$ \\
\hline 211406 & $0.045 \pm 0.010$ & 212401 & $0.571 \pm 0.014$ & 221904 & $0.243 \pm 0.012$ & 223205 & $1.640 \pm 0.019$ \\
\hline 211407 & $0.034 \pm 0.010$ & 212402 & $0.727 \pm 0.015$ & 222101 & $1.320 \pm 0.018$ & 223206 & $0.280 \pm 0.012$ \\
\hline 211408 & $0.103 \pm 0.011$ & 212403 & $0.148 \pm 0.011$ & 222102 & NoData & 223207 & $0.955 \pm 0.016$ \\
\hline 211409 & $0.078 \pm 0.011$ & 213201 & $0.782 \pm 0.015$ & 222103 & $0.069 \pm 0.011$ & 223301 & $0.707 \pm 0.015$ \\
\hline 211410 & $0.035 \pm 0.010$ & 213202 & NoData & 222201 & $0.039 \pm 0.010$ & BasinID & $1998\left(\mathrm{~km}^{2}\right)$ \\
\hline 211412 & $0.086 \pm 0.011$ & 221204 & $0.849 \pm 0.015$ & 222202 & $0.191 \pm 0.011$ & 223302 & $3.332 \pm 0.025$ \\
\hline 211413 & $0.060 \pm 0.010$ & 221205 & $0.219 \pm 0.012$ & 222203 & $0.065 \pm 0.011$ & 223303 & $0.325 \pm 0.012$ \\
\hline 211415 & $0.059 \pm 0.010$ & 221206 & $0.116 \pm 0.011$ & 222204 & $0.070 \pm 0.011$ & 223304 & $0.269 \pm 0.012$ \\
\hline 211416 & $0.044 \pm 0.010$ & 221301 & $3.453 \pm 0.026$ & 222205 & $0.788 \pm 0.015$ & 223305 & NoData \\
\hline 211501 & $0.104 \pm 0.011$ & 221302 & $2.498 \pm 0.022$ & 222206 & $1.120 \pm 0.017$ & 223401 & $0.107 \pm 0.011$ \\
\hline 211502 & $0.073 \pm 0.011$ & 221303 & $0.245 \pm 0.012$ & 222207 & $0.099 \pm 0.011$ & 223402 & $0.050 \pm 0.010$ \\
\hline 211503 & $0.044 \pm 0.010$ & 221304 & $0.294 \pm 0.012$ & 222209 & $0.031 \pm 0.010$ & 223403 & $0.055 \pm 0.010$ \\
\hline 211504 & $0.109 \pm 0.011$ & 221401 & $0.231 \pm 0.012$ & 222210 & $0.063 \pm 0.010$ & 223404 & $0.055 \pm 0.010$ \\
\hline 211505 & $0.074 \pm 0.011$ & 221402 & $0.087 \pm 0.011$ & 222301 & $0.518 \pm 0.014$ & 223405 & $0.134 \pm 0.011$ \\
\hline 211506 & $1.982 \pm 0.021$ & 221403 & $0.262 \pm 0.012$ & 222302 & $0.232 \pm 0.012$ & 223406 & $0.134 \pm 0.011$ \\
\hline 211507 & $1.088 \pm 0.017$ & 221404 & $0.021 \pm 0$ & 222303 & $0.129 \pm$ & 407 & 0.489 \\
\hline 211508 & $0.406 \pm 0.013$ & 221405 & $0.215 \pm 0.012$ & 222304 & $0.033 \pm 0.010$ & 223408 & $0.085 \pm$ \\
\hline 211509 & $0.179 \pm 0.011$ & 221406 & $0.037 \pm 0.010$ & 222305 & $0.186 \pm 0.011$ & 223501 & $0.050 \pm 0.010$ \\
\hline 211510 & $0.170 \pm 0.011$ & 221501 & $0.342 \pm 0.012$ & 222306 & $0.222 \pm 0.012$ & 223502 & $0.429 \pm 0.013$ \\
\hline 211601 & $0.039 \pm 0.010$ & 221502 & $0.026 \pm 0.010$ & 222307 & $0.081 \pm 0.011$ & 223503 & $0.195 \pm 0.011$ \\
\hline 211602 & $0.058 \pm 0.010$ & 221503 & $0.144 \pm 0.011$ & 222308 & $0.137 \pm 0.011$ & 223504 & $0.302 \pm 0.012$ \\
\hline 211603 & $0.156 \pm 0.011$ & 221601 & $0.084 \pm 0.011$ & 222309 & $0.257 \pm 0.012$ & 223601 & $0.062 \pm 0.010$ \\
\hline 211604 & $0.034 \pm 0.010$ & 221602 & $0.105 \pm 0.011$ & 222310 & NoData & 223602 & $0.104 \pm 0.011$ \\
\hline 211701 & $0.046 \pm 0.010$ & 221603 & $0.759 \pm 0.015$ & 222311 & $0.098 \pm 0.011$ & 223603 & $0.244 \pm 0.012$ \\
\hline 211702 & $0.040 \pm 0.010$ & 221604 & $0.108 \pm 0.011$ & 222312 & $0.103 \pm 0.011$ & 223604 & $0.115 \pm 0.011$ \\
\hline 211801 & $0.215 \pm 0.012$ & 221605 & $0.165 \pm 0.011$ & 222313 & $0.180 \pm 0.011$ & 223605 & $0.064 \pm 0.011$ \\
\hline 211802 & $0.110 \pm 0.011$ & 221606 & $0.575 \pm 0.014$ & 222314 & $0.715 \pm 0.015$ & 223606 & $0.668 \pm 0.014$ \\
\hline 211803 & $0.079 \pm 0.011$ & 221701 & $0.218 \pm 0.012$ & 222316 & $0.157 \pm 0.011$ & 223607 & $0.173 \pm 0.011$ \\
\hline 211804 & $0.488 \pm 0.013$ & 221702 & $0.080 \pm 0.011$ & 222401 & $0.238 \pm 0.012$ & 223609 & NoData \\
\hline 211901 & $0.118 \pm 0.011$ & 221703 & $0.088 \pm 0.011$ & 222402 & $0.182 \pm 0.011$ & 223611 & $0.303 \pm 0.012$ \\
\hline 211902 & $0.071 \pm 0.011$ & 221704 & $0.362 \pm 0.013$ & 222403 & $0.167 \pm 0.011$ & 223612 & $0.168 \pm 0.011$ \\
\hline 211905 & $0.287 \pm 0.012$ & 221705 & $0.106 \pm 0.011$ & 222404 & $0.090 \pm 0.011$ & 223701 & NoData \\
\hline 212201 & $0.526 \pm 0.014$ & 221706 & $0.162 \pm 0.011$ & 222405 & $0.112 \pm 0.011$ & 223702 & $0.512 \pm 0.014$ \\
\hline 212202 & $0.029 \pm 0.010$ & 221707 & $0.075 \pm 0.011$ & 222406 & $0.067 \pm 0.011$ & 223703 & $0.096 \pm 0.011$ \\
\hline 212203 & $0.047 \pm 0.010$ & 221708 & $0.078 \pm 0.011$ & 222407 & NoData & 224201 & $0.020 \pm 0.010$ \\
\hline
\end{tabular}




\begin{tabular}{|c|c|c|c|c|c|c|c|}
\hline BasinID & $\begin{array}{c}1998 \text { Area } \\
\left(\mathrm{km}^{2}\right)\end{array}$ & BasinID & $\begin{array}{c}1998 \text { Area } \\
\left(\mathrm{km}^{2}\right)\end{array}$ & BasinID & $\begin{array}{c}1998 \text { Area } \\
\left(\mathrm{km}^{2}\right)\end{array}$ & BasinID & $\begin{array}{c}1998 \text { Area } \\
\left(\mathrm{km}^{2}\right)\end{array}$ \\
\hline 224202 & $0.023 \pm 0.010$ & 225402 & $0.295 \pm 0.012$ & 226504 & $0.065 \pm 0.011$ & 228503 & $0.089 \pm 0.011$ \\
\hline 224203 & $0.052 \pm 0.010$ & 225403 & $0.152 \pm 0.011$ & 226505 & $0.109 \pm 0.011$ & 228504 & $0.028 \pm 0.010$ \\
\hline 224402 & $0.299 \pm 0.012$ & 225501 & $1.105 \pm 0.017$ & 226601 & $0.035 \pm 0.010$ & 228506 & $0.336 \pm 0.012$ \\
\hline 224403 & NoData & 225502 & $0.067 \pm 0.011$ & 226602 & $1.186 \pm 0.017$ & 231101 & $0.369 \pm 0.013$ \\
\hline 224404 & $0.352 \pm 0.013$ & 225503 & $0.054 \pm 0.010$ & 226702 & $0.831 \pm 0.015$ & 231102 & $0.066 \pm 0.011$ \\
\hline 224405 & $1.629 \pm 0.019$ & 225504 & $0.398 \pm 0.013$ & 226801 & $0.044 \pm 0.010$ & 231103 & NoData \\
\hline 224501 & $0.015 \pm 0.010$ & 225505 & $0.188 \pm 0.011$ & 226802 & $0.051 \pm 0.010$ & 231104 & $0.147 \pm 0.011$ \\
\hline 224502 & $0.160 \pm 0.011$ & 225506 & $0.125 \pm 0.011$ & 227103 & NoData & 231105 & $0.685 \pm 0.015$ \\
\hline 224601 & $0.072 \pm 0.011$ & 225507 & $0.053 \pm 0.010$ & 227104 & $0.176 \pm 0.011$ & 233401 & $0.088 \pm 0.011$ \\
\hline 224602 & $0.115 \pm 0.011$ & 225508 & $0.098 \pm 0.011$ & 227105 & $0.128 \pm 0.011$ & 233402 & $0.528 \pm 0.014$ \\
\hline 224603 & $0.088 \pm 0.011$ & 225510 & $0.280 \pm 0.012$ & 227107 & $0.035 \pm 0.010$ & 233403 & $0.079 \pm 0.011$ \\
\hline 224604 & $0.058 \pm 0.010$ & 225511 & $0.082 \pm 0.011$ & 227201 & $0.018 \pm 0.010$ & 233404 & $0.219 \pm 0.012$ \\
\hline 224605 & $0.051 \pm 0.010$ & 225512 & $0.822 \pm 0.015$ & 227202 & $0.063 \pm 0.010$ & 233405 & $0.723 \pm 0.015$ \\
\hline 224606 & $0.050 \pm 0.010$ & 225513 & $0.118 \pm 0.011$ & 227203 & $0.209 \pm 0.012$ & 233406 & $0.092 \pm 0.011$ \\
\hline 224607 & $0.047 \pm 0.010$ & 225514 & $0.212 \pm 0.012$ & 227204 & $0.652 \pm 0.014$ & 233407 & $0.601 \pm 0.014$ \\
\hline 224608 & $0.087 \pm 0.011$ & 225601 & $0.213 \pm 0.012$ & 227205 & $0.065 \pm 0.011$ & 233408 & NoData \\
\hline 224609 & $0.053 \pm 0.010$ & 225602 & $3.817 \pm 0.027$ & 227206 & $0.023 \pm 0.010$ & 233409 & $0.075 \pm 0.011$ \\
\hline 224610 & $0.026 \pm 0.010$ & 225701 & $1.063 \pm 0.016$ & 227207 & $0.065 \pm 0.011$ & 234201 & $0.061 \pm 0.010$ \\
\hline 224701 & $0.521 \pm 0.014$ & 225702 & $0.195 \pm 0.011$ & 227208 & $0.041 \pm 0.010$ & 234203 & $0.138 \pm 0.011$ \\
\hline 224702 & $0.218 \pm 0.012$ & 226101 & $0.057 \pm 0.010$ & 227209 & $0.091 \pm 0.011$ & 234204 & $0.385 \pm 0.013$ \\
\hline 224703 & $0.800 \pm 0.015$ & 226102 & $0.070 \pm 0.011$ & 227210 & $0.856 \pm 0.015$ & 241303 & $0.202 \pm 0.012$ \\
\hline 224704 & $0.141 \pm 0.011$ & 226103 & $0.730 \pm 0.015$ & 227211 & $0.088 \pm 0.011$ & 241304 & $0.058 \pm 0.010$ \\
\hline 224705 & $0.124 \pm 0.011$ & 226104 & $0.149 \pm 0.011$ & 227212 & $0.031 \pm 0.010$ & 241305 & NoData \\
\hline 224706 & $0.752 \pm 0.015$ & 226105 & $0.353 \pm 0.013$ & 227301 & $0.097 \pm 0.011$ & 241306 & $0.167 \pm 0.011$ \\
\hline 224707 & $0.046 \pm 0.010$ & 226106 & $0.188 \pm 0.011$ & 227302 & $0.101 \pm 0.011$ & 241307 & $0.227 \pm 0.012$ \\
\hline 224708 & $0.106 \pm 0.011$ & 226107 & $0.101 \pm 0.011$ & 227303 & $0.041 \pm 0.010$ & 241308 & $0.078 \pm 0.011$ \\
\hline 224709 & $0.030 \pm 0.010$ & 226108 & $0.237 \pm 0.012$ & 227304 & $0.120 \pm 0.011$ & 241401 & $0.106 \pm 0.011$ \\
\hline 224710 & $0.050 \pm 0.010$ & 226109 & $0.266 \pm 0.012$ & 227305 & $0.034 \pm 0.010$ & 241501 & $0.150 \pm 0.011$ \\
\hline 224711 & $0.057 \pm 0.010$ & 226110 & $0.397 \pm 0.013$ & 227306 & $1.058 \pm 0.016$ & 241503 & $0.028 \pm 0.010$ \\
\hline 224713 & $0.046 \pm 0.010$ & 226201 & $0.087 \pm 0.011$ & 227308 & $0.193 \pm 0.011$ & 241504 & $0.405 \pm 0.013$ \\
\hline 224714 & $0.161 \pm 0.011$ & 226202 & $0.080 \pm 0.011$ & 227309 & $0.112 \pm 0.011$ & 241505 & $0.043 \pm 0.010$ \\
\hline 224801 & $0.077 \pm 0.011$ & 226203 & $1.939 \pm 0.020$ & 227310 & $0.361 \pm 0.013$ & 242211 & $0.103 \pm 0.011$ \\
\hline 225101 & $0.065 \pm 0.011$ & 226205 & $0.035 \pm 0.010$ & 227311 & $0.079 \pm 0.011$ & 242212 & $0.157 \pm 0.011$ \\
\hline 225102 & $0.049 \pm 0.010$ & 226206 & $0.042 \pm 0.010$ & 227312 & $0.293 \pm 0.012$ & 242213 & $0.087 \pm 0.011$ \\
\hline 225103 & NoData & 226207 & $0.322 \pm 0.012$ & 227313 & $0.221 \pm 0.012$ & 242401 & $0.148 \pm 0.011$ \\
\hline 225104 & $0.023 \pm 0.010$ & 226208 & $0.144 \pm 0.011$ & 227402 & $0.155 \pm 0.011$ & 242602 & $0.042 \pm 0.010$ \\
\hline 225105 & $0.156 \pm 0.011$ & 226209 & $0.915 \pm 0.016$ & 224703 & $0.800 \pm 0.015$ & 242603 & $0.052 \pm 0.010$ \\
\hline 225106 & $0.096 \pm 0.011$ & 226210 & $0.050 \pm 0.010$ & 227502 & $0.039 \pm 0.010$ & 242604 & $0.045 \pm 0.010$ \\
\hline 225107 & $0.201 \pm 0.012$ & 226211 & $0.053 \pm 0.010$ & 227503 & NoData & 242605 & $0.068 \pm 0.011$ \\
\hline 225108 & $0.433 \pm 0.013$ & 226212 & $0.122 \pm 0.011$ & 227504 & $0.010 \pm 0.010$ & 242607 & $0.083 \pm 0.011$ \\
\hline 225109 & $0.868 \pm 0.016$ & 226213 & $0.263 \pm 0.012$ & 227505 & $0.326 \pm 0.012$ & 242609 & $0.043 \pm 0.010$ \\
\hline 225110 & $0.201 \pm 0.012$ & 226301 & $0.043 \pm 0.010$ & 227506 & $0.222 \pm 0.012$ & 242610 & $1.126 \pm 0.017$ \\
\hline 225111 & $0.182 \pm 0.011$ & 226302 & $0.086 \pm 0.011$ & 227507 & $0.019 \pm 0.010$ & 242611 & $0.169 \pm 0.011$ \\
\hline 225112 & $0.069 \pm 0.011$ & 226303 & $0.984 \pm 0.016$ & 227508 & $3.167 \pm 0.025$ & 242612 & $0.286 \pm 0.012$ \\
\hline 225113 & $0.208 \pm 0.012$ & 226304 & $0.283 \pm 0.012$ & 227601 & $0.119 \pm 0.011$ & 242701 & $1.308 \pm 0.018$ \\
\hline 225114 & $0.549 \pm 0.014$ & 226305 & $0.081 \pm 0.011$ & 227602 & $0.121 \pm 0.011$ & 242702 & $0.057 \pm 0.010$ \\
\hline 225115 & $0.991 \pm 0.016$ & 226306 & $0.071 \pm 0.011$ & 227603 & $2.730 \pm 0.023$ & 242703 & $0.828 \pm 0.015$ \\
\hline 225201 & $0.091 \pm 0.011$ & 226307 & $0.066 \pm 0.011$ & 227604 & $0.740 \pm 0.015$ & 242704 & $0.037 \pm 0.010$ \\
\hline 225202 & NoData & 226308 & $0.039 \pm 0.010$ & 227605 & $1.314 \pm 0.018$ & 242705 & $0.056 \pm 0.010$ \\
\hline 225203 & $0.225 \pm 0.012$ & 226401 & $0.052 \pm 0.010$ & 227606 & $1.549 \pm 0.019$ & 242706 & $0.868 \pm 0.016$ \\
\hline 225204 & $0.144 \pm 0.011$ & 226402 & $0.053 \pm 0.010$ & 227607 & $2.463 \pm 0.022$ & 242707 & $1.253 \pm 0.017$ \\
\hline 225205 & $6.536 \pm 0.034$ & 226403 & $0.032 \pm 0.010$ & 227608 & $0.969 \pm 0.016$ & 242708 & $0.345 \pm 0.012$ \\
\hline 225301 & $0.077 \pm 0.011$ & 226404 & $0.173 \pm 0.011$ & 227609 & $1.380 \pm 0.018$ & 242801 & $0.063 \pm 0.011$ \\
\hline 225302 & $0.302 \pm 0.012$ & 226405 & $0.070 \pm 0.011$ & 227701 & $0.230 \pm 0.012$ & 242802 & $0.337 \pm 0.012$ \\
\hline 225303 & $1.658 \pm 0.019$ & 226406 & $2.269 \pm 0.022$ & 227702 & $1.461 \pm 0.018$ & 244206 & $0.031 \pm 0.010$ \\
\hline 225304 & $0.158 \pm 0.011$ & 226407 & $0.451 \pm 0.013$ & 227703 & $0.860 \pm 0.015$ & 244209 & $0.042 \pm 0.010$ \\
\hline 225305 & $0.107 \pm 0.011$ & 226408 & $0.432 \pm 0.013$ & 227801 & $0.080 \pm 0.011$ & 244210 & $0.092 \pm 0.011$ \\
\hline 225306 & $4.461 \pm 0.029$ & 226410 & $0.031 \pm 0.010$ & 227802 & $1.034 \pm 0.016$ & 244213 & $0.310 \pm 0.012$ \\
\hline 225307 & $0.537 \pm 0.014$ & 226411 & $0.095 \pm 0.011$ & 227901 & $0.071 \pm 0.011$ & 244214 & $0.089 \pm 0.011$ \\
\hline 225308 & $0.119 \pm 0.011$ & 226413 & $0.051 \pm 0.010$ & 228103 & $0.107 \pm 0.011$ & 244218 & $0.684 \pm 0.015$ \\
\hline 225309 & $2.115 \pm 0.021$ & 226501 & $0.056 \pm 0.010$ & 228201 & $0.287 \pm 0.012$ & 244219 & $0.071 \pm 0.011$ \\
\hline 225310 & $1.685 \pm 0.019$ & 226502 & $0.787 \pm 0.015$ & 228202 & $0.123 \pm 0.011$ & 244220 & $0.051 \pm 0.010$ \\
\hline \multirow[t]{2}{*}{225401} & $0.220 \pm 0.012$ & 226503 & $0.068 \pm 0.011$ & 228203 & $1.907 \pm 0.020$ & 244302 & $0.672 \pm 0.014$ \\
\hline & & & & 228401 & $0.724 \pm 0.015$ & 244305 & $0.084 \pm 0.011$ \\
\hline
\end{tabular}




\begin{tabular}{|c|c|c|c|c|c|c|c|c|c|c|}
\hline BasinID & $\begin{array}{c}1998 \text { Area } \\
\left(\mathrm{km}^{2}\right)\end{array}$ & BasinID & \multicolumn{2}{|c|}{$\begin{array}{c}1998 \text { Area } \\
\left(\mathrm{km}^{2}\right)\end{array}$} & BasinID & \multicolumn{2}{|c|}{$\begin{array}{c}1998 \text { Area } \\
\left(\mathrm{km}^{2}\right)\end{array}$} & BasinID & \multicolumn{2}{|c|}{$\begin{array}{c}1998 \text { Area } \\
\left(\mathrm{km}^{2}\right)\end{array}$} \\
\hline 244306 & $0.038 \pm 0.010$ & 244504 & \multicolumn{2}{|c|}{$1.542 \pm 0.019$} & 244611 & \multicolumn{2}{|c|}{ NoData } & 244710 & 0.301 & 0.012 \\
\hline 244307 & $0.202 \pm 0.012$ & 244505 & $0.292 \pm 0$ & 0.012 & 244612 & $0.036 \pm$ & 0.010 & 244711 & 0.046 & \pm 0.010 \\
\hline 244308 & $0.234 \pm 0.012$ & 244506 & $0.030 \pm 0$ & 0.010 & 244613 & $0.137 \pm$ & 0.011 & 244712 & 0.256 & \pm 0.012 \\
\hline 244401 & $0.108 \pm 0.011$ & 244507 & $0.158 \pm 0$ & 0.011 & 244614 & $0.052 \pm$ & 0.010 & 244713 & 0.079 & \pm 0.011 \\
\hline 244402 & $0.081 \pm 0.011$ & 244508 & $0.151 \pm 0$ & 0.011 & 244615 & $0.040 \pm$ & 0.010 & 244714 & 0.059 & \pm 0.010 \\
\hline 244403 & $0.296 \pm 0.012$ & 244509 & NoData & & 244616 & $0.052 \pm$ & 0.010 & 244801 & 0.021 & \pm 0.010 \\
\hline 244404 & $0.037 \pm 0.010$ & 244510 & $0.061 \pm 0$ & 0.010 & 244617 & $0.039 \pm$ & 0.010 & 244802 & 0.023 & \pm 0.010 \\
\hline 244405 & $0.017 \pm 0.010$ & 244511 & $0.223 \pm 0$ & 0.012 & 244618 & $0.015 \pm$ & 0.010 & 244805 & 0.141 & $\begin{array}{l} \pm 0.011 \\
\end{array}$ \\
\hline 244406 & $0.086 \pm 0.011$ & 244512 & $0.264 \pm 0$ & 0.012 & 244619 & NoData & & 244806 & 0.057 & \pm 0.010 \\
\hline 244407 & $4.721 \pm 0.029$ & 244513 & $0.039 \pm 0$ & 0.010 & 244620 & $0.309 \pm$ & 0.012 & 244807 & 0.113 & \pm 0.011 \\
\hline 244408 & $1.522 \pm 0.019$ & 244514 & $0.055 \pm 0$ & 0.010 & 244621 & $0.296 \pm$ & 0.012 & 244808 & 0.203 & \pm 0.012 \\
\hline 244409 & $0.930 \pm 0.016$ & 244515 & $0.112 \pm 0$ & 0.011 & 244622 & $0.240 \pm$ & 0.012 & 244809 & 0.089 & \pm 0.011 \\
\hline 244410 & $0.045 \pm 0.010$ & 244516 & $0.063 \pm 0$ & 0.011 & 244623 & $0.056 \pm$ & 0.010 & 244810 & 0.134 & \pm 0.011 \\
\hline 244411 & $0.054 \pm 0.010$ & 244517 & $0.035 \pm 0$ & 0.010 & 244624 & NoData & & 244811 & 0.015 & \pm 0.010 \\
\hline 244412 & $0.024 \pm 0.010$ & 244518 & $0.020 \pm 0$ & 0.010 & 244625 & $0.012 \pm$ & 0.010 & 245303 & 0.050 & \pm 0.010 \\
\hline 244413 & $0.032 \pm 0.010$ & 244519 & $0.025 \pm 0$ & 0.010 & 244701 & $0.020 \pm$ & 0.010 & 245304 & 0.101 & \pm 0.011 \\
\hline 244414 & $0.071 \pm 0.011$ & 244601 & $0.093 \pm 0$ & 0.011 & 244702 & $0.077 \pm$ & 011 & 245401 & 0.016 & \pm 0.010 \\
\hline 244415 & $0.126 \pm 0.011$ & 244602 & $0.271 \pm 0$ & 0.012 & 244703 & $0.550 \pm$ & 0.014 & 245402 & 0.046 & 0.010 \\
\hline 244416 & $0.116 \pm 0.011$ & 244603 & $0.110 \pm 0$ & 0.011 & 244704 & $0.189 \pm$ & 0.011 & 245403 & 0.032 & \pm 0.010 \\
\hline 244417 & $0.250 \pm 0.012$ & 244604 & $0.069 \pm 0$ & 0.011 & 244705 & $0.041 \pm$ & 0.010 & 245404 & 0.006 & \pm 0.010 \\
\hline 244501 & $0.017 \pm 0.010$ & 244605 & $0.023 \pm 0$ & 0.010 & 244706 & $0.086 \pm$ & 0.011 & 245405 & 0.034 & \pm 0.010 \\
\hline 244502 & $0.023 \pm 0.010$ & 244606 & $0.031 \pm 0$ & 0.010 & 244707 & $0.031 \pm$ & 0.010 & 245501 & $\mathrm{NoDa}$ & \\
\hline 244503 & $0.144 \pm 0.011$ & 244607 & $0.156 \pm 0$ & 0.011 & 244708 & $0.888 \pm$ & 0.016 & 246501 & 0.043 & \pm 0.010 \\
\hline & & 244608 & $0.059 \pm 0$ & 0.010 & 244709 & $0.100 \pm$ & & 246502 & 0.042 & \pm 0.010 \\
\hline & & 244609 & & & & & & 246302 & 0.039 & \pm 0.010 \\
\hline & & & & & & & & 224712 & 0.102 & \pm 0.011 \\
\hline & 2009 Area & Souce & & & & $\bar{e}$ & & $2009 \mathrm{~A}$ & & Source \\
\hline BasinID & $\left(\mathrm{km}^{2}\right)$ & Year & asinID & & & $\mathrm{Ye}$ & BasinID & & & Year \\
\hline 211101 & $0.021 \pm 0.002$ & 2009 & 211416 & 0.022 & 010 & 2009 & 212211 & $0.024 \pm$ & .010 & 2009 \\
\hline 211102 & $0.012 \pm 0.010$ & 2009 & 211501 & 0.096 & 0.011 & 2009 & 212212 & $0.209 \pm$ & .012 & 2009 \\
\hline 211103 & $0.006 \pm 0.010$ & 2009 & 211502 & 0.042 & 0.010 & 2006 & 212301 & $0.031 \pm C$ & .010 & 2009 \\
\hline 211104 & $0.457 \pm 0.013$ & 2009 & 211503 & 0.024 & 0.010 & 2009 & 212302 & $0.427 \pm c$ & .013 & 2009 \\
\hline 211201 & $0.033 \pm 0.010$ & 2009 & 211504 & 0.094 & 0.011 & 2009 & 212303 & $0.358 \pm c$ & .013 & 2009 \\
\hline 211202 & $0.010 \pm 0.010$ & 2006 & 211505 & 0.059 & 0.010 & 2009 & 212304 & $1.973 \pm C$ & .020 & 2009 \\
\hline 211203 & $0.049 \pm 0.010$ & 2006 & 211506 & 1.804 & 0.020 & 2009 & 212305 & $0.062 \pm C$ & .010 & 2009 \\
\hline 211204 & $0.034 \pm 0.010$ & 2006 & 211507 & 0.965 & 0.016 & 2009 & 212306 & $1.219 \pm$ & .017 & 2009 \\
\hline 211205 & $0.005+0.010$ & 2009 & 211508 & 0.311 & 0.012 & 2009 & 212307 & $0.100 \pm$ & .011 & 2009 \\
\hline 211206 & $0.046 \pm 0.010$ & 2009 & 211509 & 0.146 & 0.011 & 2009 & 212401 & $0.505 \pm c$ & .013 & 2009 \\
\hline 211207 & $0.015 \pm 0.010$ & 2009 & 211510 & 0.137 & 0.011 & 2009 & 212402 & $0.551 \pm C$ & .014 & 2009 \\
\hline 211208 & $0.047 \pm 0.010$ & 2009 & 211601 & 0.037 & 0.010 & 2009 & 212403 & $0.125 \pm c$ & .011 & 2009 \\
\hline 211209 & $0.151 \pm 0.011$ & 2009 & 211602 & 0.052 & 0.010 & 2009 & 212404 & $0.047 \pm c$ & .010 & 2009 \\
\hline 211210 & $0.701 \pm 0.015$ & 2009 & 211603 & 0.09 & 0.011 & 2009 & 212501 & $0.061 \pm C$ & .010 & 2009 \\
\hline 211211 & $0.194 \pm 0.011$ & 2009 & 211604 & 0.11 & 0.011 & 2009 & 212601 & $0.064 \pm$ & .011 & 2009 \\
\hline 211302 & $0.041 \pm 0.010$ & 2009 & 211701 & 0.03 & 0.010 & 2009 & 212602 & $0.275 \pm c$ & .012 & 2009 \\
\hline 211303 & $0.013+0.010$ & 2009 & 211702 & 0.02 & 0.010 & 2009 & 212603 & $1.130 \pm c$ & .017 & 2009 \\
\hline 211304 & $0.010 \pm 0.010$ & 2009 & 211801 & 0.18 & 0.011 & 2009 & 212604 & $4.843 \pm 0$ & .030 & 2009 \\
\hline 211305 & $0.054 \pm 0.010$ & 2006 & 211802 & 0.108 & 0.011 & 2009 & 212605 & $0.213 \pm C$ & .012 & 2009 \\
\hline 211306 & $0.014 \pm 0.010$ & 2009 & 211803 & 0.05 & 0.010 & 2009 & 212606 & $0.177 \pm c$ & .011 & 2009 \\
\hline 211307 & $0.032 \pm 0.010$ & 2009 & 211804 & 0.307 & 0.012 & 2009 & 212607 & $0.055 \pm c$ & .010 & 2009 \\
\hline 211401 & $0.039 \pm 0.010$ & 2009 & 211901 & 0.061 & 0.010 & 2009 & 212608 & $0.586 \pm C$ & .014 & 2009 \\
\hline 211402 & $0.037 \pm 0.010$ & 2009 & 211902 & 0.025 & 0.010 & 2009 & 212609 & $0.116 \pm C$ & .011 & 2009 \\
\hline 211403 & $0.013 \pm 0.010$ & 2009 & 211905 & 0.13 & 0.011 & 2009 & 212610 & $0.072 \pm$ & .011 & 2009 \\
\hline 211404 & $0.009+0.010$ & 2009 & 212101 & 0.115 & 0.011 & 2009 & 212701 & $0.199 \pm$ & .012 & 2009 \\
\hline 211405 & $0.022 \pm 0.010$ & 2009 & 212102 & 0.01 & 0.010 & 2009 & 212702 & $3.649 \pm 0$ & .026 & 2009 \\
\hline 211406 & $0.024 \pm 0.010$ & 2009 & 212201 & 0.363 & 0.013 & 2009 & 212703 & $4.636 \pm 0$ & .029 & 2009 \\
\hline 211407 & $0.022 \pm 0.010$ & 2009 & 212202 & 0.013 & 0.010 & 2009 & 212704 & $2.208 \pm c$ & .021 & 2006 \\
\hline 211408 & $0.068 \pm 0.011$ & 2009 & 212203 & 0.02 & 0.010 & 2009 & 213101 & $0.838 \pm c$ & .015 & 2009 \\
\hline 211409 & $0.040 \pm 0.010$ & 2009 & 212204 & 0.008 & 0.010 & 2009 & 213102 & $0.224 \pm C$ & .012 & 2009 \\
\hline 211410 & $0.020 \pm 0.010$ & 2009 & 212205 & 0.061 & 0.010 & 2009 & 213104 & $0.085 \pm C$ & .011 & 2009 \\
\hline 211411 & $0.006 \pm 0.010$ & 2009 & 212206 & 0.02 & 0.010 & 2009 & 213105 & $4.642 \pm c$ & .029 & 2009 \\
\hline 211412 & $0.047+0.010$ & 2009 & 212207 & 0.05 & 0.010 & 2009 & 213201 & $0.581 \pm$ & .014 & 2009 \\
\hline 211413 & $0.028 \pm 0.010$ & 2009 & 212208 & 0.06 & 0.010 & 2009 & 213202 & $0.923 \pm$ & .016 & 2009 \\
\hline 211414 & $0.014 \pm 0.010$ & 2009 & 212209 & 0.08 & 0.011 & 2009 & 221101 & $2.674 \pm C$ & .023 & 2009 \\
\hline 211415 & $0.041 \pm 0.010$ & 2009 & 212210 & 0.02 & 0.010 & 2009 & 221102 & $1.925 \pm c$ & .020 & 2009 \\
\hline
\end{tabular}




\begin{tabular}{|c|c|c|c|c|c|c|c|c|}
\hline BasinID & $\begin{array}{l}2009 \text { Area } \\
\left(\mathrm{km}^{2}\right)\end{array}$ & $\begin{array}{c}\text { Source } \\
\text { Year }\end{array}$ & BasinID & $\begin{array}{l}2009 \text { Area } \\
\left(\mathrm{km}^{2}\right)\end{array}$ & $\begin{array}{c}\text { Source } \\
\text { Year }\end{array}$ & BasinID & $\begin{array}{c}2009 \text { Area } \\
\left(\mathrm{km}^{2}\right)\end{array}$ & $\begin{array}{c}\text { Source } \\
\text { Year }\end{array}$ \\
\hline 221103 & $3.466 \pm 0.026$ & 2009 & 222202 & $0.134 \pm 0.011$ & 2009 & 223501 & $0.043 \pm 0.010$ & 2009 \\
\hline 221104 & $2.945 \pm 0.024$ & 2009 & 222203 & $0.025 \pm 0.010$ & 2009 & 223502 & $0.405 \pm 0.013$ & 2009 \\
\hline 221105 & $0.072 \pm 0.011$ & 2009 & 222204 & $0.053 \pm 0.010$ & 2009 & 223503 & $0.170 \pm 0.011$ & 2009 \\
\hline 221106 & $0.155 \pm 0.011$ & 2009 & 222205 & $0.683 \pm 0.015$ & 2009 & 223504 & $0.284 \pm 0.012$ & 2009 \\
\hline 221107 & $0.217 \pm 0.012$ & 2009 & 222206 & $0.972 \pm 0.016$ & 2009 & 223601 & $0.066 \pm 0.011$ & 2009 \\
\hline 221108 & $1.734 \pm 0.020$ & 2009 & 222207 & $0.055 \pm 0.010$ & 2009 & 223602 & $0.101 \pm 0.011$ & 2009 \\
\hline 221109 & $0.272 \pm 0.012$ & 2009 & 222208 & $0.230 \pm 0.012$ & 2009 & 223603 & $0.252 \pm 0.012$ & 2009 \\
\hline 221110 & $0.152 \pm 0.011$ & 2009 & 222209 & $0.031 \pm 0.010$ & 2006 & 223604 & $0.138 \pm 0.011$ & 2009 \\
\hline 221202 & $0.084 \pm 0.011$ & 2009 & 222210 & $0.032 \pm 0.010$ & 2009 & 223605 & $0.060 \pm 0.010$ & 2009 \\
\hline 221203 & $0.113 \pm 0.011$ & 2009 & 222301 & $0.301 \pm 0.012$ & 2009 & 223606 & $0.479 \pm 0.013$ & 2009 \\
\hline 221204 & $0.845 \pm 0.015$ & 2009 & 222302 & $0.090 \pm 0.011$ & 2009 & 223607 & $0.148 \pm 0.011$ & 2009 \\
\hline 221205 & $0.182 \pm 0.011$ & 2009 & 222303 & $0.091 \pm 0.011$ & 2009 & 223608 & $0.306 \pm 0.012$ & 2009 \\
\hline 221206 & $0.102 \pm 0.011$ & 2009 & 222304 & $0.019 \pm 0.010$ & 2009 & 223609 & $0.036 \pm 0.010$ & 2009 \\
\hline 221301 & $3.089 \pm 0.025$ & 2009 & 222305 & $0.171 \pm 0.011$ & 2009 & 223610 & $0.493 \pm 0.013$ & 2009 \\
\hline 221302 & $2.375 \pm 0.022$ & 2006 & 222306 & $0.147 \pm 0.011$ & 2009 & 223611 & $0.258 \pm 0.012$ & 2009 \\
\hline 221303 & $0.127 \pm 0.011$ & 2009 & 222307 & $0.036 \pm 0.010$ & 2009 & 223612 & $0.138 \pm 0.011$ & 2009 \\
\hline 221304 & $0.224 \pm 0.012$ & 2009 & 222308 & $0.078 \pm 0.011$ & 2009 & 223701 & $0.075 \pm 0.011$ & 2009 \\
\hline 221401 & $0.133 \pm 0.011$ & 2009 & 222309 & $0.142 \pm 0.011$ & 2009 & 223702 & $0.478 \pm 0.013$ & 2009 \\
\hline 221402 & $0.043 \pm 0.010$ & 2009 & 222310 & $0.010 \pm 0.010$ & 2009 & 223703 & $0.064 \pm 0.011$ & 2009 \\
\hline 221403 & $0.120 \pm 0.011$ & 2009 & 222311 & $0.076 \pm 0.011$ & 2009 & 224201 & $0.015 \pm 0.010$ & 2006 \\
\hline 221404 & $0.005 \pm 0.010$ & 2009 & 222312 & $0.083 \pm 0.011$ & 2009 & 224202 & $0.022 \pm 0.010$ & 2006 \\
\hline 221405 & $0.089 \pm 0.011$ & 2009 & 222313 & $0.145 \pm 0.011$ & 2009 & 224203 & $0.041 \pm 0.010$ & 2006 \\
\hline 221406 & $0.014 \pm 0.010$ & 2009 & 222314 & $0.610 \pm 0.014$ & 2009 & 224401 & $0.041 \pm 0.010$ & 2009 \\
\hline 221501 & $0.279 \pm 0.012$ & 2009 & 222315 & $0.116 \pm 0.011$ & 2006 & 224402 & $0.247 \pm 0.012$ & 2009 \\
\hline 221502 & $0.020 \pm 0.010$ & 2009 & 222316 & $0.046 \pm 0.010$ & 2006 & 224404 & $0.335 \pm 0.012$ & 2009 \\
\hline 221503 & $0.105 \pm 0.011$ & 2009 & 222401 & $0.195 \pm 0.011$ & 2009 & 224405 & $1.552 \pm 0.019$ & 2009 \\
\hline 221504 & $0.082 \pm 0.011$ & 2009 & 222402 & $0.156 \pm 0.011$ & 2009 & 224501 & $0.013 \pm 0.010$ & 2009 \\
\hline 221601 & $0.058 \pm 0.010$ & 2009 & 222403 & $0.178 \pm 0.011$ & 2009 & 224502 & $0.142 \pm 0.011$ & 2009 \\
\hline 221602 & $0.081 \pm 0.011$ & 2009 & 222404 & $0.077 \pm 0.011$ & 2009 & 224601 & $0.068 \pm 0.011$ & 2006 \\
\hline 221603 & $0.656 \pm 0.014$ & 2009 & 222405 & $0.095 \pm 0.011$ & 2009 & 224602 & $0.095 \pm 0.011$ & 2006 \\
\hline 221604 & $0.092 \pm 0.011$ & 2009 & 222406 & $0.102 \pm 0.011$ & 2009 & 224603 & $0.074 \pm 0.011$ & 2006 \\
\hline 221605 & $0.103 \pm 0.011$ & 2009 & 222407 & $0.063 \pm 0.011$ & 2009 & 224605 & $0.043 \pm 0.010$ & 2006 \\
\hline 221606 & $0.267 \pm 0.012$ & 2009 & 222408 & $0.267 \pm 0.012$ & 2009 & 224606 & $0.046 \pm 0.010$ & 2009 \\
\hline 221701 & $0.179 \pm 0.011$ & 2009 & 222501 & $0.367 \pm 0.013$ & 2009 & 224607 & $0.033 \pm 0.010$ & 2006 \\
\hline 221702 & $0.074 \pm 0.011$ & 2006 & 222502 & $0.159 \pm 0.011$ & 2009 & 224608 & $0.090 \pm 0.011$ & 2009 \\
\hline 221703 & $0.050 \pm 0.010$ & 2009 & 222601 & $0.086 \pm 0.011$ & 2009 & 224609 & $0.049 \pm 0.010$ & 2009 \\
\hline 221704 & $0.168 \pm 0.011$ & 2009 & 222602 & $0.096 \pm 0.011$ & 2009 & 224610 & $0.024 \pm 0.010$ & 2009 \\
\hline 221705 & $0.071 \pm 0.011$ & 2009 & 222603 & $0.174 \pm 0.011$ & 2009 & 224701 & $0.457 \pm 0.013$ & 2006 \\
\hline 221706 & $0.141 \pm 0.011$ & 2009 & 222701 & $0.093 \pm 0.011$ & 2009 & 224702 & $0.211 \pm 0.012$ & 2006 \\
\hline 221707 & $0.052 \pm 0.010$ & 2009 & 223101 & $0.418 \pm 0.013$ & 2009 & 224703 & $0.765 \pm 0.015$ & 2006 \\
\hline 221708 & $0.048 \pm 0.010$ & 2009 & 223102 & $0.773 \pm 0.015$ & 2009 & 224704 & $0.122 \pm 0.011$ & 2006 \\
\hline 221709 & $0.108 \pm 0.011$ & 2009 & 223103 & $0.098 \pm 0.011$ & 2009 & 224705 & $0.102 \pm 0.011$ & 2006 \\
\hline 221710 & $0.043 \pm 0.010$ & 2009 & 223104 & $0.070 \pm 0.011$ & 2009 & 224706 & $0.637 \pm 0.014$ & 2009 \\
\hline 221711 & $0.057 \pm 0.010$ & 2009 & 223105 & $0.554 \pm 0.014$ & 2009 & 224707 & $0.032 \pm 0.010$ & 2006 \\
\hline 221712 & $0.031 \pm 0.010$ & 2009 & 223201 & $0.111 \pm 0.011$ & 2009 & 224708 & $0.077 \pm 0.011$ & 2006 \\
\hline 221713 & $0.041 \pm 0.010$ & 2009 & 223202 & $0.228 \pm 0.012$ & 2009 & 224709 & $0.026 \pm 0.010$ & 2006 \\
\hline 221714 & $0.295 \pm 0.012$ & 2009 & 223203 & $0.362 \pm 0.013$ & 2009 & 224710 & $0.044 \pm 0.010$ & 2006 \\
\hline 221801 & $0.177 \pm 0.011$ & 2009 & 223204 & $0.300 \pm 0.012$ & 2009 & 224711 & $0.046 \pm 0.010$ & 2006 \\
\hline 221802 & $0.039 \pm 0.010$ & 2009 & 223205 & $1.648 \pm 0.019$ & 2009 & 224713 & $0.043 \pm 0.010$ & 2009 \\
\hline 221803 & $0.036 \pm 0.010$ & 2009 & 223206 & $0.213 \pm 0.012$ & 2009 & 224714 & $0.153 \pm 0.011$ & 2006 \\
\hline 221804 & $0.189 \pm 0.011$ & 2009 & 223207 & $0.864 \pm 0.015$ & 2009 & 224801 & $0.052 \pm 0.010$ & 2009 \\
\hline 221805 & $0.118 \pm 0.011$ & 2009 & 223301 & $0.586 \pm 0.014$ & 2009 & 225101 & $0.050 \pm 0.010$ & 2009 \\
\hline 221806 & $0.012 \pm 0.010$ & 2009 & 223302 & $2.926 \pm 0.024$ & 2009 & 225102 & $0.039 \pm 0.010$ & 2006 \\
\hline 221807 & $0.059 \pm 0.010$ & 2009 & 223303 & $0.211 \pm 0.012$ & 2009 & 225103 & $0.023 \pm 0.010$ & 2009 \\
\hline 221808 & $0.093 \pm 0.011$ & 2009 & 223304 & $0.192 \pm 0.011$ & 2009 & 225104 & $0.022 \pm 0.010$ & 2009 \\
\hline 221809 & $0.955 \pm 0.016$ & 2009 & 223305 & $0.007 \pm 0.010$ & 2009 & 225105 & $0.107 \pm 0.011$ & 2006 \\
\hline 221901 & $0.535 \pm 0.014$ & 2009 & 223401 & $0.103 \pm 0.011$ & 2009 & 225106 & $0.091 \pm 0.011$ & 2006 \\
\hline 221902 & $0.103 \pm 0.011$ & 2009 & 223402 & $0.040 \pm 0.010$ & 2009 & 225107 & $0.176 \pm 0.011$ & 2006 \\
\hline 221903 & $0.084 \pm 0.011$ & 2009 & 223403 & $0.040 \pm 0.010$ & 2009 & 225108 & $0.313 \pm 0.012$ & 2009 \\
\hline 221904 & $0.177 \pm 0.011$ & 2009 & 223404 & $0.050 \pm 0.010$ & 2009 & 225109 & $0.754 \pm 0.015$ & 2009 \\
\hline 222101 & $1.144 \pm 0.017$ & 2009 & 223405 & $0.123 \pm 0.011$ & 2009 & 225110 & $0.180 \pm 0.011$ & 2006 \\
\hline 222102 & $0.010 \pm 0.010$ & 2009 & 223406 & $0.098 \pm 0.011$ & 2009 & 225111 & $0.161 \pm 0.011$ & 2006 \\
\hline 222103 & $0.054 \pm 0.010$ & 2009 & 223407 & $0.496 \pm 0.013$ & 2009 & 225112 & $0.056 \pm 0.010$ & 2006 \\
\hline 222201 & $0.038 \pm 0.010$ & 2009 & 223408 & $0.079 \pm 0.011$ & 2009 & 225113 & $0.187 \pm 0.011$ & 2006 \\
\hline
\end{tabular}




\begin{tabular}{|c|c|c|c|c|c|c|c|c|}
\hline BasinID & $\begin{array}{l}2009 \text { Area } \\
\left(\mathrm{km}^{2}\right)\end{array}$ & $\begin{array}{c}\text { Source } \\
\text { Year }\end{array}$ & BasinID & $\begin{array}{l}2009 \text { Area } \\
\left(\mathrm{km}^{2}\right)\end{array}$ & $\begin{array}{c}\text { Source } \\
\text { Year }\end{array}$ & BasinID & $\begin{array}{c}2009 \text { Area } \\
\left(\mathrm{km}^{2}\right)\end{array}$ & $\begin{array}{c}\text { Source } \\
\text { Year }\end{array}$ \\
\hline 225114 & $0.363 \pm 0.013$ & 2009 & 226306 & $0.063 \pm 0.010$ & 2006 & 227506 & $0.262 \pm 0.012$ & 2006 \\
\hline 225115 & $0.905 \pm 0.016$ & 2009 & 226307 & $0.056 \pm 0.010$ & 2006 & 227508 & $2.741 \pm 0.023$ & 2009 \\
\hline 225201 & $0.064 \pm 0.011$ & 2006 & 226308 & $0.036 \pm 0.010$ & 2006 & 227601 & $0.105 \pm 0.011$ & 2009 \\
\hline 225202 & $0.052 \pm 0.010$ & 2009 & 226401 & $0.047 \pm 0.010$ & 2006 & 227602 & $0.093 \pm 0.011$ & 2009 \\
\hline 225203 & $0.163 \pm 0.011$ & 2006 & 226402 & $0.050 \pm 0.010$ & 2006 & 227603 & $2.674 \pm 0.023$ & 2009 \\
\hline 225204 & $0.125 \pm 0.011$ & 2006 & 226403 & $0.028 \pm 0.010$ & 2009 & 227604 & $0.640 \pm 0.014$ & 2006 \\
\hline 225205 & $6.100 \pm 0.033$ & 2009 & 226404 & $0.136 \pm 0.011$ & 2006 & 227605 & $1.296 \pm 0.018$ & 2006 \\
\hline 225301 & $0.077 \pm 0.011$ & 2009 & 226405 & $0.056 \pm 0.010$ & 2006 & 227606 & $1.421 \pm 0.018$ & 2009 \\
\hline 225302 & $0.239 \pm 0.012$ & 2009 & 226406 & $2.018 \pm 0.021$ & 2009 & 227607 & $2.247 \pm 0.022$ & 2009 \\
\hline 225303 & $1.643 \pm 0.019$ & 2009 & 226407 & $0.349 \pm 0.013$ & 2006 & 227608 & $0.890 \pm 0.016$ & 2009 \\
\hline 225304 & $0.125 \pm 0.011$ & 2006 & 226408 & $0.400 \pm 0.013$ & 2006 & 227609 & $1.310 \pm 0.018$ & 2006 \\
\hline 225305 & $0.086 \pm 0.011$ & 2006 & 226410 & $0.025 \pm 0.010$ & 2009 & 227701 & $0.176 \pm 0.011$ & 2006 \\
\hline 225306 & $4.237 \pm 0.028$ & 2006 & 226411 & $0.085 \pm 0.011$ & 2009 & 227702 & $1.287 \pm 0.018$ & 2006 \\
\hline 225307 & $0.480 \pm 0.013$ & 2006 & 226412 & $0.049 \pm 0.010$ & 2009 & 227703 & $0.831 \pm 0.015$ & 2006 \\
\hline 225308 & $0.090 \pm 0.011$ & 2006 & 226413 & $0.032 \pm 0.010$ & 2009 & 227801 & $0.065 \pm 0.011$ & 2006 \\
\hline 225309 & $1.959 \pm 0.020$ & 2006 & 226501 & $0.052 \pm 0.010$ & 2009 & 227802 & $0.881 \pm 0.016$ & 2006 \\
\hline 225310 & $1.472 \pm 0.018$ & 2006 & 226502 & $0.692 \pm 0.015$ & 2009 & 227803 & $0.038 \pm 0.010$ & 2006 \\
\hline 225401 & $0.193 \pm 0.011$ & 2009 & 226503 & $0.038 \pm 0.010$ & 2006 & 227903 & $0.066 \pm 0.011$ & 2009 \\
\hline 225402 & $0.283 \pm 0.012$ & 2009 & 226504 & $0.057 \pm 0.010$ & 2009 & 227904 & $0.117 \pm 0.011$ & 2009 \\
\hline 225403 & $0.144 \pm 0.011$ & 2006 & 226505 & $0.097 \pm 0.011$ & 2009 & 228101 & $1.474 \pm 0.018$ & 2006 \\
\hline 225501 & $0.927 \pm 0.016$ & 2009 & 226602 & $0.945 \pm 0.016$ & 2009 & 228102 & $0.742 \pm 0.015$ & 2006 \\
\hline 225502 & $0.046 \pm 0.010$ & 2009 & 226603 & $0.090 \pm 0.011$ & 2009 & 228103 & $0.062 \pm 0.010$ & 2006 \\
\hline 225503 & $0.058 \pm 0.010$ & 2009 & 226604 & $0.039 \pm 0.010$ & 2006 & 228104 & $0.374 \pm 0.013$ & 2006 \\
\hline 225504 & $0.383 \pm 0.013$ & 2006 & 226701 & $0.254 \pm 0.012$ & 2009 & 228105 & $0.429 \pm 0.013$ & 2006 \\
\hline 225505 & $0.146 \pm 0.011$ & 2006 & 226702 & $0.693 \pm 0.015$ & 2009 & 228201 & $0.295 \pm 0.012$ & 2006 \\
\hline 225506 & $0.142 \pm 0.011$ & 2006 & 226801 & $0.033 \pm 0.010$ & 2009 & 228202 & $0.135 \pm 0.011$ & 2006 \\
\hline 225507 & $0.039 \pm 0.010$ & 2006 & 226802 & $0.033 \pm 0.010$ & 2009 & 228203 & $1.375 \pm 0.018$ & 2006 \\
\hline 225508 & $0.080 \pm 0.011$ & 2006 & 226803 & $0.097 \pm 0.011$ & 2009 & 228204 & $0.141 \pm 0.011$ & 2006 \\
\hline 225509 & $4.792 \pm 0.030$ & 2009 & 226804 & $0.052 \pm 0.010$ & 2009 & 228307 & $0.049 \pm 0.010$ & 2009 \\
\hline 225510 & $0.267 \pm 0.012$ & 2006 & 226905 & $0.018 \pm 0.010$ & 2006 & 228401 & $0.632 \pm 0.014$ & 2009 \\
\hline 225511 & $0.078 \pm 0.011$ & 2006 & 227103 & $0.079 \pm 0.011$ & 2009 & 228402 & $0.104 \pm 0.011$ & 2009 \\
\hline 225512 & $0.681 \pm 0.015$ & 2006 & 227104 & $0.156 \pm 0.011$ & 2009 & 228404 & $0.369 \pm 0.013$ & 2009 \\
\hline 225513 & $0.111 \pm 0.011$ & 2006 & 227105 & $0.112 \pm 0.011$ & 2009 & 228406 & $0.372 \pm 0.013$ & 2009 \\
\hline 225514 & $0.203 \pm 0.012$ & 2009 & 227106 & $0.022 \pm 0.010$ & 2009 & 228407 & $0.086 \pm 0.011$ & 2006 \\
\hline 225601 & $0.182 \pm 0.011$ & 2009 & 227107 & $0.028 \pm 0.010$ & 2009 & 228503 & $0.078 \pm 0.011$ & 2009 \\
\hline 225602 & $3.682 \pm 0.026$ & 2009 & 227201 & $0.018 \pm 0.010$ & 2006 & 228504 & $0.026 \pm 0.010$ & 2009 \\
\hline 225701 & $0.768 \pm 0.015$ & 2009 & 227202 & $0.056 \pm 0.010$ & 2009 & 228505 & $0.096 \pm 0.011$ & 2009 \\
\hline 225702 & $0.192 \pm 0.011$ & 2009 & 227203 & $0.192 \pm 0.011$ & 2009 & 228506 & $0.282 \pm 0.012$ & 2009 \\
\hline 226101 & $0.057 \pm 0.010$ & 2006 & 227204 & $0.598 \pm 0.014$ & 2009 & 228507 & $0.081 \pm 0.011$ & 2009 \\
\hline 226102 & $0.068 \pm 0.011$ & 2006 & 227205 & $0.054 \pm 0.010$ & 2006 & 228601 & $0.055 \pm 0.010$ & 2009 \\
\hline 226103 & $0.701 \pm 0.015$ & 2006 & 227206 & $0.023 \pm 0.010$ & 2006 & 228602 & $0.060 \pm 0.010$ & 2009 \\
\hline 226104 & $0.137 \pm 0.011$ & 2009 & 227207 & $0.057 \pm 0.010$ & 2006 & 228603 & $0.158 \pm 0.011$ & 2009 \\
\hline 226105 & $0.341 \pm 0.012$ & 2009 & 227208 & $0.033 \pm 0.010$ & 2006 & 228604 & $0.207 \pm 0.012$ & 2009 \\
\hline 226106 & $0.179 \pm 0.011$ & 2009 & 227209 & $0.062 \pm 0.010$ & 2009 & 231101 & $0.286 \pm 0.012$ & 2009 \\
\hline 226107 & $0.089 \pm 0.011$ & 2006 & 227210 & $0.794 \pm 0.015$ & 2009 & 231102 & $0.027 \pm 0.010$ & 2009 \\
\hline 226108 & $0.269 \pm 0.012$ & 2009 & 227211 & $0.078 \pm 0.011$ & 2006 & 231104 & $0.125 \pm 0.011$ & 2009 \\
\hline 226109 & $0.226 \pm 0.012$ & 2009 & 227212 & $0.026 \pm 0.010$ & 2009 & 231105 & $0.565 \pm 0.014$ & 2009 \\
\hline 226110 & $0.320 \pm 0.012$ & 2009 & 227301 & $0.075 \pm 0.011$ & 2006 & 233101 & $0.169 \pm 0.011$ & 2009 \\
\hline 226201 & $0.087 \pm 0.011$ & 2006 & 227302 & $0.075 \pm 0.011$ & 2006 & 233201 & $0.037 \pm 0.010$ & 2009 \\
\hline 226203 & $1.858 \pm 0.020$ & 2006 & 227303 & $0.033 \pm 0.010$ & 2006 & 233202 & $0.039 \pm 0.010$ & 2009 \\
\hline 226205 & $0.033 \pm 0.010$ & 2006 & 227304 & $0.100 \pm 0.011$ & 2006 & 233203 & $0.072 \pm 0.011$ & 2009 \\
\hline 226206 & $0.042 \pm 0.010$ & 2006 & 227305 & $0.026 \pm 0.010$ & 2006 & 233204 & $0.742 \pm 0.015$ & 2009 \\
\hline 226207 & $0.255 \pm 0.012$ & 2006 & 227306 & $1.008 \pm 0.016$ & 2009 & 233205 & $0.090 \pm 0.011$ & 2009 \\
\hline 226208 & $0.132 \pm 0.011$ & 2006 & 227307 & $0.117 \pm 0.011$ & 2009 & 233206 & $0.081 \pm 0.011$ & 2009 \\
\hline 226209 & $0.775 \pm 0.015$ & 2006 & 227308 & $0.164 \pm 0.011$ & 2006 & 233207 & $0.026 \pm 0.010$ & 2009 \\
\hline 226210 & $0.050 \pm 0.010$ & 2006 & 227309 & $0.106 \pm 0.011$ & 2006 & 233208 & $0.118 \pm 0.011$ & 2009 \\
\hline 226211 & $0.050 \pm 0.010$ & 2006 & 227310 & $0.335 \pm 0.012$ & 2006 & 233209 & $0.028 \pm 0.010$ & 2009 \\
\hline 226212 & $0.118 \pm 0.011$ & 2009 & 227311 & $0.071 \pm 0.011$ & 2006 & 233401 & $0.095 \pm 0.011$ & 2006 \\
\hline 226213 & $0.259 \pm 0.012$ & 2009 & 227312 & $0.268 \pm 0.012$ & 2006 & 233402 & $0.525 \pm 0.014$ & 2006 \\
\hline 226301 & $0.042 \pm 0.010$ & 2009 & 227313 & $0.227 \pm 0.012$ & 2006 & 233403 & $0.113 \pm 0.011$ & 2006 \\
\hline 226302 & $0.074 \pm 0.011$ & 2006 & 227402 & $0.171 \pm 0.011$ & 2006 & 233404 & $0.200 \pm 0.012$ & 2006 \\
\hline 226303 & $0.870 \pm 0.016$ & 2009 & 224703 & $0.765 \pm 0.015$ & 2006 & 233405 & $0.714 \pm 0.015$ & 2006 \\
\hline 226304 & $0.277 \pm 0.012$ & 2009 & 227501 & $0.105 \pm 0.011$ & 2006 & 233406 & $0.116 \pm 0.011$ & 2006 \\
\hline 226305 & $0.066 \pm 0.011$ & 2006 & 227505 & $0.332 \pm 0.012$ & 2006 & 233407 & $0.611 \pm 0.014$ & 2006 \\
\hline
\end{tabular}




\begin{tabular}{|c|c|c|c|c|c|c|c|c|}
\hline BasinID & $\begin{array}{c}2009 \text { Area } \\
\left(\mathrm{km}^{2}\right)\end{array}$ & $\begin{array}{c}\text { Source } \\
\text { Year }\end{array}$ & BasinID & $\begin{array}{l}2009 \text { Area } \\
\left(\mathrm{km}^{2}\right)\end{array}$ & $\begin{array}{c}\text { Source } \\
\text { Year }\end{array}$ & BasinID & $\begin{array}{c}2009 \text { Area } \\
\left(\mathrm{km}^{2}\right)\end{array}$ & $\begin{array}{c}\text { Source } \\
\text { Year }\end{array}$ \\
\hline 233409 & $0.054 \pm 0.010$ & 2006 & 244203 & $0.036 \pm 0.010$ & 2006 & 244604 & $0.068 \pm 0.011$ & 2006 \\
\hline 234201 & $0.051 \pm 0.010$ & 2006 & 244204 & $0.140 \pm 0.011$ & 2006 & 244605 & $0.025 \pm 0.010$ & 2006 \\
\hline 234202 & $0.056 \pm 0.010$ & 2006 & 244205 & $0.163 \pm 0.011$ & 2006 & 244606 & $0.030 \pm 0.010$ & 2006 \\
\hline 234203 & $0.116 \pm 0.011$ & 2006 & 244206 & $0.035 \pm 0.010$ & 2006 & 244607 & $0.152 \pm 0.011$ & 2006 \\
\hline 234204 & $0.325 \pm 0.012$ & 2006 & 244207 & $0.155 \pm 0.011$ & 2006 & 244608 & $0.059 \pm 0.010$ & 2006 \\
\hline 241302 & $0.122 \pm 0.011$ & 2006 & 244209 & $0.041 \pm 0.010$ & 2006 & 244609 & $0.274 \pm 0.012$ & 2009 \\
\hline 241303 & $0.178 \pm 0.011$ & 2006 & 244210 & $0.082 \pm 0.011$ & 2006 & 244610 & $0.158 \pm 0.011$ & 2006 \\
\hline 241304 & $0.045 \pm 0.010$ & 2006 & 244211 & $0.036 \pm 0.010$ & 2006 & 244612 & $0.033 \pm 0.010$ & 2006 \\
\hline 241305 & $0.402 \pm 0.013$ & 2006 & 244212 & $0.049 \pm 0.010$ & 2006 & 244613 & $0.123 \pm 0.011$ & 2006 \\
\hline 241306 & $0.002 \pm 0.010$ & 2009 & 244213 & $0.305 \pm 0.012$ & 2006 & 244615 & $0.040 \pm 0.010$ & 2006 \\
\hline 241307 & $0.213 \pm 0.012$ & 2009 & 244215 & $0.093 \pm 0.011$ & 2006 & 244616 & $0.052 \pm 0.010$ & 2006 \\
\hline 241308 & $0.068 \pm 0.011$ & 2006 & 244217 & $0.386 \pm 0.013$ & 2006 & 244617 & $0.041 \pm 0.010$ & 2006 \\
\hline 241401 & $0.081 \pm 0.011$ & 2006 & 244219 & $0.085 \pm 0.011$ & 2006 & 244618 & $0.015 \pm 0.010$ & 2006 \\
\hline 241501 & $0.137 \pm 0.011$ & 2006 & 244220 & $0.034 \pm 0.010$ & 2006 & 244620 & $0.304 \pm 0.012$ & 2006 \\
\hline 241502 & $0.028 \pm 0.010$ & 2006 & 244221 & $1.110 \pm 0.017$ & 2006 & 244621 & $0.291 \pm 0.012$ & 2006 \\
\hline 241503 & $0.028 \pm 0.010$ & 2006 & 244222 & $0.184 \pm 0.011$ & 2006 & 244622 & $0.240 \pm 0.012$ & 2006 \\
\hline 241504 & $0.345 \pm 0.012$ & 2006 & 244223 & $0.017 \pm 0.010$ & 2006 & 244623 & $0.057 \pm 0.010$ & 2006 \\
\hline 242201 & $0.052 \pm 0.010$ & 2006 & 244301 & $0.004 \pm 0.010$ & 2006 & 244624 & $0.016 \pm 0.010$ & 2006 \\
\hline 242204 & $0.032 \pm 0.010$ & 2006 & 244302 & $0.599 \pm 0.014$ & 2006 & 244625 & $0.012 \pm 0.010$ & 2006 \\
\hline 242205 & $0.035 \pm 0.010$ & 2006 & 244303 & $0.291 \pm 0.012$ & 2006 & 244701 & $0.020 \pm 0.010$ & 2006 \\
\hline 242206 & $0.025 \pm 0.010$ & 2006 & 244305 & $0.076 \pm 0.011$ & 2006 & 244702 & $0.057 \pm 0.010$ & 2006 \\
\hline 242207 & $0.129 \pm 0.011$ & 2006 & 244306 & $0.053 \pm 0.010$ & 2006 & 244703 & $0.587 \pm 0.014$ & 2006 \\
\hline 242209 & $0.067 \pm 0.011$ & 2006 & 244307 & $0.241 \pm 0.012$ & 2006 & 244704 & $0.191 \pm 0.011$ & 2006 \\
\hline 242210 & $0.020 \pm 0.010$ & 2006 & 244308 & $0.231 \pm 0.012$ & 2006 & 244705 & $0.037 \pm 0.010$ & 2006 \\
\hline 242211 & $0.105 \pm 0.011$ & 2006 & 244401 & $0.113 \pm 0.011$ & 2006 & 244706 & $0.090 \pm 0.011$ & 2006 \\
\hline 242213 & $0.081 \pm 0.011$ & 2006 & 244402 & $0.082 \pm 0.011$ & 2006 & 244707 & $0.036 \pm 0.010$ & 2006 \\
\hline 242601 & $0.067 \pm 0.011$ & 2006 & 244403 & $0.257 \pm 0.012$ & 2006 & 244708 & $0.817 \pm 0.015$ & 2006 \\
\hline 242602 & $0.038 \pm 0.010$ & 2006 & 244404 & $0.030 \pm 0.010$ & 2006 & 244709 & $0.098 \pm 0.011$ & 2006 \\
\hline 242604 & $0.037 \pm 0.010$ & 2006 & 244405 & $0.014 \pm 0.010$ & 2006 & 244710 & $0.251 \pm 0.012$ & 2009 \\
\hline 242605 & $0.050 \pm 0.010$ & 2006 & 244406 & $0.071 \pm 0.011$ & 2006 & 244711 & $0.040 \pm 0.010$ & 2006 \\
\hline 242606 & $0.051 \pm 0.010$ & 2009 & 244407 & $4.487 \pm 0.029$ & 2009 & 244712 & $0.222 \pm 0.012$ & 2009 \\
\hline 242607 & $0.095 \pm 0.011$ & 2006 & 244408 & $1.409 \pm 0.018$ & 2009 & 244713 & $0.027 \pm 0.010$ & 2006 \\
\hline 242608 & $0.164 \pm 0.011$ & 2006 & 244409 & $0.787 \pm 0.015$ & 2009 & 244801 & $0.013 \pm 0.010$ & 2006 \\
\hline 242609 & $0.062 \pm 0.010$ & 2006 & 244410 & $0.039 \pm 0.010$ & 2009 & 244802 & $0.020 \pm 0.010$ & 2006 \\
\hline 242610 & $1.040 \pm 0.016$ & 2006 & 244411 & $0.054 \pm 0.010$ & 2009 & 244803 & $0.129 \pm 0.011$ & 2006 \\
\hline 242611 & $0.114 \pm 0.011$ & 2009 & 244412 & $0.031 \pm 0.010$ & 2006 & 244804 & $0.016 \pm 0.010$ & 2006 \\
\hline 242612 & $0.250 \pm 0.012$ & 2006 & 244413 & $0.028 \pm 0.010$ & 2006 & 244805 & $0.125 \pm 0.011$ & 2006 \\
\hline 242701 & $1.441 \pm 0.018$ & 2006 & 244414 & $0.061 \pm 0.010$ & 2006 & 244806 & $0.055 \pm 0.010$ & 2006 \\
\hline 242702 & $0.068 \pm 0.011$ & 2006 & 244415 & $0.118 \pm 0.011$ & 2006 & 244807 & $0.100 \pm 0.011$ & 2006 \\
\hline 242703 & $0.801 \pm 0.015$ & 2006 & 244416 & $0.098 \pm 0.011$ & 2006 & 244808 & $0.192 \pm 0.011$ & 2006 \\
\hline 242704 & $0.049 \pm 0.010$ & 2006 & 244417 & $0.222 \pm 0.012$ & 2006 & 244809 & $0.079 \pm 0.011$ & 2006 \\
\hline 242705 & $0.046 \pm 0.010$ & 2006 & 244501 & $0.016 \pm 0.010$ & 2006 & 244810 & $0.113 \pm 0.011$ & 2006 \\
\hline 242706 & $0.901 \pm 0.016$ & 2006 & 244502 & $0.019 \pm 0.010$ & 2006 & 244811 & $0.018 \pm 0.010$ & 2006 \\
\hline 242707 & $1.210 \pm 0.017$ & 2006 & 244503 & $0.151 \pm 0.011$ & 2006 & 245303 & $0.052 \pm 0.010$ & 2006 \\
\hline 242708 & $0.334 \pm 0.012$ & 2006 & 244504 & $1.524 \pm 0.019$ & 2006 & 245304 & $0.107 \pm 0.011$ & 2006 \\
\hline 242709 & $0.120 \pm 0.011$ & 2006 & 244505 & $0.250 \pm 0.012$ & 2006 & 245305 & $0.136 \pm 0.011$ & 2006 \\
\hline 242802 & $0.343 \pm 0.012$ & 2006 & 244506 & $0.029 \pm 0.010$ & 2009 & 245306 & $0.019 \pm 0.010$ & 2006 \\
\hline 242803 & $0.092 \pm 0.011$ & 2006 & 244507 & $0.130 \pm 0.011$ & 2006 & 245307 & $0.015 \pm 0.010$ & 2006 \\
\hline 242804 & $0.107 \pm 0.011$ & 2006 & 244508 & $0.136 \pm 0.011$ & 2006 & 245401 & $0.013 \pm 0.010$ & 2006 \\
\hline 242805 & $0.000 \pm 0.010$ & 2006 & 244509 & $0.020 \pm 0.010$ & 2006 & 245402 & $0.042 \pm 0.010$ & 2006 \\
\hline 243101 & $0.020 \pm 0.010$ & 2006 & 244510 & $0.049 \pm 0.010$ & 2006 & 245403 & $0.023 \pm 0.010$ & 2006 \\
\hline 243102 & $0.109 \pm 0.011$ & 2006 & 244511 & $0.214 \pm 0.012$ & 2006 & 245404 & $0.007 \pm 0.010$ & 2006 \\
\hline 243103 & $0.098 \pm 0.011$ & 2006 & 244512 & $0.248 \pm 0.012$ & 2006 & 245405 & $0.033 \pm 0.010$ & 2006 \\
\hline 243104 & $0.057 \pm 0.010$ & 2006 & 244513 & $0.034 \pm 0.010$ & 2006 & 246501 & $0.040 \pm 0.010$ & 2006 \\
\hline 243105 & $0.085 \pm 0.011$ & 2006 & 244514 & $0.051 \pm 0.010$ & 2006 & 246502 & $0.033 \pm 0.010$ & 2006 \\
\hline 243106 & $0.058 \pm 0.010$ & 2006 & 244515 & $0.099 \pm 0.011$ & 2006 & 245509 & $0.027 \pm 0.010$ & 2006 \\
\hline 243201 & $0.076 \pm 0.011$ & 2006 & 244516 & $0.068 \pm 0.011$ & 2006 & 246301 & $0.007 \pm 0.010$ & 2006 \\
\hline 243202 & $0.074 \pm 0.011$ & 2006 & 244517 & $0.038 \pm 0.010$ & 2006 & 246302 & $0.043 \pm 0.010$ & 2006 \\
\hline 243203 & $0.545 \pm 0.014$ & 2006 & 244518 & $0.020 \pm 0.010$ & 2009 & 246303 & $0.039 \pm 0.010$ & 2006 \\
\hline 243204 & $0.243 \pm 0.012$ & 2006 & 244519 & $0.021 \pm 0.010$ & 2006 & 246304 & $0.014 \pm 0.010$ & 2006 \\
\hline 243205 & $0.105 \pm 0.011$ & 2006 & 244601 & $0.092 \pm 0.011$ & 2006 & 246305 & $0.014 \pm 0.010$ & 2006 \\
\hline 244201 & $0.144 \pm 0.011$ & 2006 & 244602 & $0.258 \pm 0.012$ & 2006 & 246306 & $0.017 \pm 0.010$ & 2006 \\
\hline \multirow[t]{2}{*}{244202} & $0.132 \pm 0.011$ & 2006 & 244603 & $0.117 \pm 0.011$ & 2009 & 246307 & $0.032 \pm 0.010$ & 2006 \\
\hline & & & & & & 224712 & $0.084 \pm 0.011$ & 2006 \\
\hline
\end{tabular}




\section{Appendix C - Climate Data}

Average PRISM data for the grid cells where glaciers are located. Mean emperature is reported in ${ }^{\circ}$ Celsius and mean precipitation is in $\mathrm{cm}$.

\begin{tabular}{|c|c|c|c|c|c|c|c|c|c|c|}
\hline Year & $\begin{array}{c}\text { Annual } \\
\text { Max } \\
\text { Temp } \\
\end{array}$ & $\begin{array}{l}\text { Annual } \\
\text { Mean } \\
\text { Precip } \\
\end{array}$ & $\begin{array}{c}\text { Summer } \\
\text { Max } \\
\text { Temp }\end{array}$ & $\begin{array}{c}\text { Summer } \\
\text { Mean } \\
\text { Precip }\end{array}$ & $\begin{array}{c}\text { Spring } \\
\text { Max } \\
\text { Temp } \\
\end{array}$ & $\begin{array}{l}\text { Spring } \\
\text { Mean } \\
\text { Precip } \\
\end{array}$ & $\begin{array}{c}\text { Winter } \\
\text { Max } \\
\text { Temp } \\
\end{array}$ & $\begin{array}{l}\text { Winter } \\
\text { Mean } \\
\text { Precip } \\
\end{array}$ & $\begin{array}{c}\text { Fall } \\
\text { Max } \\
\text { Temp } \\
\end{array}$ & $\begin{array}{c}\text { Fall } \\
\text { Mean } \\
\text { Precip } \\
\end{array}$ \\
\hline 1900 & 7.38 & 199 & 14.56 & 80 & 10.31 & 130 & 0.98 & 308 & 2.92 & 290 \\
\hline 1901 & 7.56 & 183 & 15.04 & 62 & 8.92 & 128 & -0.66 & 271 & 7.65 & 308 \\
\hline 1902 & 6.87 & 212 & 15.36 & 70 & 8.70 & 137 & -1.26 & 349 & 4.31 & 298 \\
\hline 1903 & 6.26 & 213 & 14.02 & 107 & 8.25 & 95 & -1.38 & 321 & 4.07 & 330 \\
\hline 1904 & 7.26 & 201 & 15.72 & 53 & 10.10 & 100 & -1.82 & 372 & 5.68 & 259 \\
\hline 1905 & 7.04 & 182 & 15.52 & 92 & 10.07 & 103 & -0.70 & 261 & 2.52 & 283 \\
\hline 1906 & 7.58 & 210 & 16.45 & 95 & 9.55 & 119 & -0.33 & 281 & 3.69 & 384 \\
\hline 1907 & 6.93 & 187 & 15.11 & 73 & 9.43 & 98 & -2.26 & 322 & 6.42 & 233 \\
\hline 1908 & 7.48 & 197 & 16.62 & 53 & 8.51 & 136 & -1.22 & 337 & 5.55 & 268 \\
\hline 1909 & 6.33 & 206 & 15.97 & 63 & 7.80 & 88 & -2.48 & 306 & 3.18 & 413 \\
\hline 1910 & 7.35 & 232 & 15.81 & 58 & 11.44 & 130 & -1.06 & 350 & 3.14 & 446 \\
\hline 1911 & 6.44 & 181 & 15.15 & 81 & 7.52 & 134 & -1.26 & 259 & 3.32 & 272 \\
\hline 1912 & 6.86 & 204 & 14.78 & 90 & 8.81 & 110 & -0.26 & 314 & 3.27 & 308 \\
\hline 1913 & 6.25 & 189 & 15.39 & 90 & 8.52 & 117 & -2.28 & 261 & 2.72 & 318 \\
\hline 1914 & 7.76 & 191 & 15.93 & 78 & 11.00 & 112 & -0.80 & 275 & 5.29 & 326 \\
\hline 1915 & 8.23 & 211 & 17.39 & 52 & 10.41 & 148 & 0.59 & 322 & 3.03 & 370 \\
\hline 1916 & 6.09 & 201 & 15.64 & 75 & 8.36 & 122 & -3.21 & 353 & 3.33 & 229 \\
\hline 1917 & 7.14 & 229 & 16.95 & 67 & 6.90 & 148 & -1.91 & 459 & 5.89 & 172 \\
\hline 1918 & 7.77 & 208 & 16.98 & 60 & 9.18 & 84 & -0.55 & 346 & 4.58 & 353 \\
\hline 1919 & 7.01 & 210 & 16.56 & 63 & 9.05 & 151 & -1.11 & 378 & 2.08 & 226 \\
\hline 1920 & 7.01 & 208 & 15.87 & 119 & 6.37 & 115 & 0.27 & 279 & 3.41 & 336 \\
\hline 1921 & 6.72 & 246 & 14.81 & 88 & 8.41 & 125 & -1.03 & 378 & 4.34 & 420 \\
\hline 1922 & 6.31 & 172 & 16.73 & 64 & 7.25 & 96 & -3.54 & 286 & 4.25 & 236 \\
\hline 1923 & 7.60 & 194 & 16.71 & 74 & 8.96 & 116 & -1.33 & 342 & 5.89 & 214 \\
\hline 1924 & 7.26 & 186 & 15.87 & 64 & 10.04 & 89 & -0.62 & 298 & 3.02 & 302 \\
\hline 1925 & 8.23 & 187 & 17.00 & 45 & 10.49 & 102 & 0.55 & 355 & 3.79 & 222 \\
\hline 1926 & 8.84 & 188 & 16.95 & 70 & 11.24 & 116 & 1.21 & 280 & 5.50 & 310 \\
\hline 1927 & 6.67 & 240 & 16.42 & 93 & 7.26 & 167 & -1.82 & 339 & 3.58 & 412 \\
\hline 1928 & 7.86 & 189 & 16.81 & 57 & 9.95 & 144 & -0.24 & 298 & 4.09 & 281 \\
\hline 1929 & 7.16 & 144 & 16.77 & 55 & 8.00 & 135 & -2.01 & 256 & 5.46 & 106 \\
\hline 1930 & 7.04 & 163 & 16.31 & 58 & 9.34 & 138 & -1.50 & 254 & 3.27 & 216 \\
\hline 1931 & 8.17 & 231 & 16.81 & 110 & 11.02 & 131 & 0.20 & 388 & 4.01 & 259 \\
\hline 1932 & 7.29 & 248 & 16.72 & 67 & 9.13 & 120 & -1.82 & 385 & 4.83 & 466 \\
\hline 1933 & 7.37 & 249 & 16.40 & 103 & 7.90 & 85 & -1.37 & 454 & 6.25 & 297 \\
\hline 1934 & 9.68 & 243 & 16.91 & 68 & 12.97 & 122 & 2.70 & 363 & 5.91 & 471 \\
\hline 1935 & 7.64 & 174 & 16.87 & 86 & 9.47 & 68 & -0.56 & 315 & 3.74 & 176 \\
\hline 1936 & 7.91 & 188 & 17.26 & 88 & 11.04 & 115 & -2.27 & 381 & 6.47 & 77 \\
\hline 1937 & 7.19 & 229 & 16.82 & 94 & 7.65 & 192 & -2.26 & 295 & 6.38 & 403 \\
\hline 1938 & 9.17 & 171 & 18.95 & 36 & 10.98 & 109 & 0.20 & 299 & 5.75 & 248 \\
\hline 1939 & 8.83 & 185 & 16.96 & 59 & 10.98 & 102 & 0.99 & 327 & 6.08 & 237 \\
\hline 1940 & 8.91 & 192 & 17.91 & 52 & 10.93 & 132 & 1.38 & 294 & 3.96 & 330 \\
\hline 1941 & 8.77 & 189 & 16.23 & 106 & 11.08 & 135 & 1.99 & 238 & 5.09 & 314 \\
\hline 1942 & 8.15 & 174 & 17.92 & 73 & 9.14 & 116 & -0.06 & 229 & 4.03 & 321 \\
\hline 1943 & 7.95 & 172 & 17.26 & 67 & 9.08 & 156 & -0.85 & 278 & 5.80 & 188 \\
\hline 1944 & 8.36 & 157 & 17.13 & 86 & 9.91 & 121 & -0.06 & 212 & 6.13 & 226 \\
\hline 1945 & 7.75 & 217 & 16.58 & 66 & 8.65 & 141 & 0.04 & 332 & 4.58 & 365 \\
\hline 1946 & 7.55 & 220 & 16.38 & 72 & 9.83 & 119 & -0.19 & 365 & 3.08 & 326 \\
\hline 1947 & 8.15 & 207 & 16.23 & 82 & 11.21 & 97 & 0.50 & 328 & 4.23 & 326 \\
\hline 1948 & 6.37 & 246 & 15.33 & 122 & 6.69 & 209 & -1.69 & 334 & 4.27 & 355 \\
\hline 1949 & 7.05 & 217 & 15.66 & 88 & 10.35 & 98 & -2.47 & 331 & 5.58 & 365 \\
\hline 1950 & 6.34 & 253 & 16.98 & 78 & 6.71 & 151 & -2.88 & 404 & 3.14 & 402 \\
\hline 1951 & 7.13 & 216 & 17.38 & 63 & 10.16 & 87 & -2.73 & 374 & 3.31 & 333 \\
\hline 1952 & 8.00 & 141 & 16.85 & 66 & 9.29 & 101 & -1.22 & 256 & 7.44 & 99 \\
\hline 1953 & 8.34 & 244 & 16.28 & 92 & 8.46 & 124 & 1.46 & 432 & 6.13 & 292 \\
\hline 1954 & 6.69 & 220 & 14.11 & 100 & 7.64 & 137 & -0.51 & 326 & 5.31 & 330 \\
\hline 1955 & 5.75 & 240 & 15.38 & 67 & 6.06 & 177 & -1.95 & 326 & 1.59 & 476 \\
\hline 1956 & 7.27 & 209 & 16.40 & 108 & 11.20 & 51 & -1.62 & 351 & 2.87 & 284 \\
\hline
\end{tabular}




\begin{tabular}{|c|c|c|c|c|c|c|c|c|c|c|}
\hline 1957 & 7.69 & 173 & 16.60 & 64 & 10.82 & 100 & -1.18 & 311 & 4.46 & 188 \\
\hline 1958 & 9.37 & 212 & 18.80 & 71 & 11.52 & 133 & 1.38 & 298 & 4.34 & 404 \\
\hline 1959 & 7.16 & 246 & 15.70 & 126 & 8.64 & 190 & -0.47 & 333 & 3.89 & 367 \\
\hline 1960 & 7.41 & 202 & 16.66 & 61 & 8.14 & 203 & -0.78 & 263 & 4.58 & 364 \\
\hline 1961 & 7.95 & 232 & 18.19 & 72 & 7.74 & 146 & 0.46 & 410 & 2.63 & 283 \\
\hline 1962 & 7.35 & 197 & 15.85 & 87 & 7.50 & 159 & -0.06 & 257 & 5.01 & 333 \\
\hline 1963 & 7.59 & 194 & 16.24 & 83 & 8.55 & 138 & 0.09 & 244 & 4.32 & 372 \\
\hline 1964 & 6.56 & 214 & 14.71 & 104 & 7.89 & 136 & -1.27 & 336 & 4.61 & 271 \\
\hline 1965 & 7.80 & 186 & 16.22 & 57 & 9.37 & 149 & -0.50 & 306 & 5.97 & 241 \\
\hline 1966 & 7.41 & 204 & 15.74 & 82 & 9.34 & 98 & -0.31 & 326 & 4.23 & 310 \\
\hline 1967 & 8.34 & 233 & 18.82 & 56 & 7.47 & 95 & 0.11 & 393 & 4.74 & 404 \\
\hline 1968 & 6.92 & 236 & 15.69 & 123 & 7.95 & 127 & -0.52 & 360 & 3.24 & 325 \\
\hline 1969 & 7.35 & 178 & 16.99 & 94 & 9.60 & 149 & -2.04 & 276 & 4.58 & 181 \\
\hline 1970 & 7.44 & 196 & 17.25 & 70 & 7.81 & 157 & -0.72 & 306 & 3.75 & 265 \\
\hline 1971 & 6.54 & 230 & 15.78 & 82 & 8.90 & 112 & -1.90 & 396 & 2.56 & 315 \\
\hline 1972 & 6.60 & 251 & 15.36 & 128 & 7.90 & 172 & -1.79 & 462 & 4.55 & 153 \\
\hline 1973 & 7.32 & 181 & 16.34 & 58 & 9.70 & 111 & -0.25 & 259 & 2.03 & 342 \\
\hline 1974 & 7.76 & 237 & 17.31 & 63 & 7.58 & 150 & -0.65 & 442 & 5.68 & 263 \\
\hline 1975 & 6.69 & 246 & 15.94 & 63 & 7.90 & 115 & -1.56 & 388 & 3.48 & 458 \\
\hline 1976 & 6.98 & 179 & 14.95 & 79 & 8.80 & 121 & -1.01 & 320 & 5.20 & 159 \\
\hline 1977 & 7.50 & 210 & 16.48 & 87 & 9.60 & 115 & -0.57 & 310 & 3.55 & 352 \\
\hline 1978 & 7.24 & 164 & 16.13 & 107 & 8.47 & 127 & -0.75 & 225 & 4.21 & 193 \\
\hline 1979 & 7.88 & 184 & 17.44 & 73 & 9.82 & 118 & -1.29 & 342 & 5.16 & 159 \\
\hline 1980 & 7.01 & 212 & 14.93 & 95 & 9.98 & 137 & -1.63 & 319 & 5.49 & 306 \\
\hline 1981 & 7.82 & 204 & 16.08 & 112 & 8.56 & 200 & 0.78 & 267 & 4.69 & 263 \\
\hline 1982 & 6.87 & 227 & 16.38 & 96 & 8.33 & 130 & -1.22 & 387 & 2.57 & 265 \\
\hline 1983 & 7.50 & 228 & 15.33 & 132 & 11.06 & 122 & -0.57 & 311 & 4.39 & 362 \\
\hline 1984 & 6.85 & 228 & 16.20 & 79 & 7.43 & 192 & -0.53 & 322 & 2.32 & 375 \\
\hline 1985 & 6.84 & 165 & 17.33 & 79 & 9.84 & 145 & -1.80 & 156 & 0.12 & 375 \\
\hline 1986 & 8.18 & 206 & 17.15 & 74 & 8.64 & 136 & 0.19 & 304 & 5.77 & 348 \\
\hline 1987 & 9.25 & 169 & 18.08 & 54 & 11.57 & 159 & 0.01 & 305 & 7.75 & 136 \\
\hline 1988 & 7.93 & 211 & 16.22 & 86 & 9.96 & 176 & -0.01 & 272 & 5.20 & 373 \\
\hline 1989 & 7.71 & 188 & 16.43 & 56 & 10.59 & 153 & -1.02 & 264 & 4.86 & 339 \\
\hline 1990 & 7.82 & 261 & 17.79 & 81 & 10.15 & 112 & -0.95 & 362 & 3.10 & 568 \\
\hline 1991 & 8.02 & 200 & 16.72 & 69 & 9.03 & 177 & 0.34 & 303 & 5.01 & 280 \\
\hline 1992 & 9.10 & 180 & 17.60 & 104 & 12.26 & 116 & 1.37 & 255 & 4.41 & 250 \\
\hline 1993 & 7.46 & 161 & 15.44 & 100 & 10.67 & 162 & -0.97 & 214 & 5.15 & 179 \\
\hline 1994 & 8.68 & 204 & 18.37 & 67 & 11.53 & 101 & 0.36 & 315 & 3.09 & 357 \\
\hline 1995 & 8.31 & 229 & 17.22 & 84 & 11.35 & 96 & 0.11 & 303 & 3.84 & 505 \\
\hline 1996 & 7.33 & 227 & 17.81 & 60 & 8.03 & 192 & -1.34 & 358 & 3.01 & 335 \\
\hline 1997 & 9.53 & 279 & 19.22 & 141 & 11.30 & 173 & 0.80 & 433 & 5.82 & 357 \\
\hline 1998 & 9.55 & 209 & 19.84 & 39 & 10.53 & 96 & 0.71 & 357 & 5.66 & 363 \\
\hline 1999 & 8.44 & 245 & 17.17 & 69 & 8.66 & 100 & 0.65 & 434 & 6.32 & 362 \\
\hline 2000 & 8.12 & 152 & 16.63 & 82 & 10.37 & 139 & 0.63 & 228 & 3.82 & 151 \\
\hline 2001 & 8.79 & 174 & 18.38 & 64 & 9.32 & 133 & 2.10 & 211 & 2.45 & 358 \\
\hline 2002 & 9.13 & 183 & 18.67 & 54 & 9.65 & 178 & 0.17 & 344 & 7.47 & 122 \\
\hline 2003 & 10.01 & 224 & 20.45 & 36 & 10.11 & 109 & 1.80 & 325 & 5.44 & 512 \\
\hline 2004 & 10.31 & 179 & 19.20 & 115 & 12.63 & 95 & 2.21 & 245 & 6.39 & 261 \\
\hline 2005 & 9.97 & 164 & 18.38 & 75 & 12.30 & 125 & 2.55 & 229 & 5.67 & 251 \\
\hline 2006 & 8.40 & 215 & 17.61 & 48 & 9.20 & 90 & 0.72 & 325 & 4.54 & 454 \\
\hline 2007 & 8.03 & 178 & 15.85 & 56 & 9.34 & 84 & 1.43 & 330 & 4.30 & 213 \\
\hline 2008 & 7.45 & 167 & 15.52 & 67 & 7.55 & 87 & 0.05 & 259 & 6.01 & 264 \\
\hline 2009 & 8.06 & 174 & 17.44 & 51 & 8.78 & 137 & 0.28 & 207 & 4.15 & 389 \\
\hline
\end{tabular}




\section{Supplemental CD}

Name: NOCA_GlacierInventory.gdb

File Type: File geodatabase

Size: 14.1 MB

Required Application Software: ArcGIS 10.1 